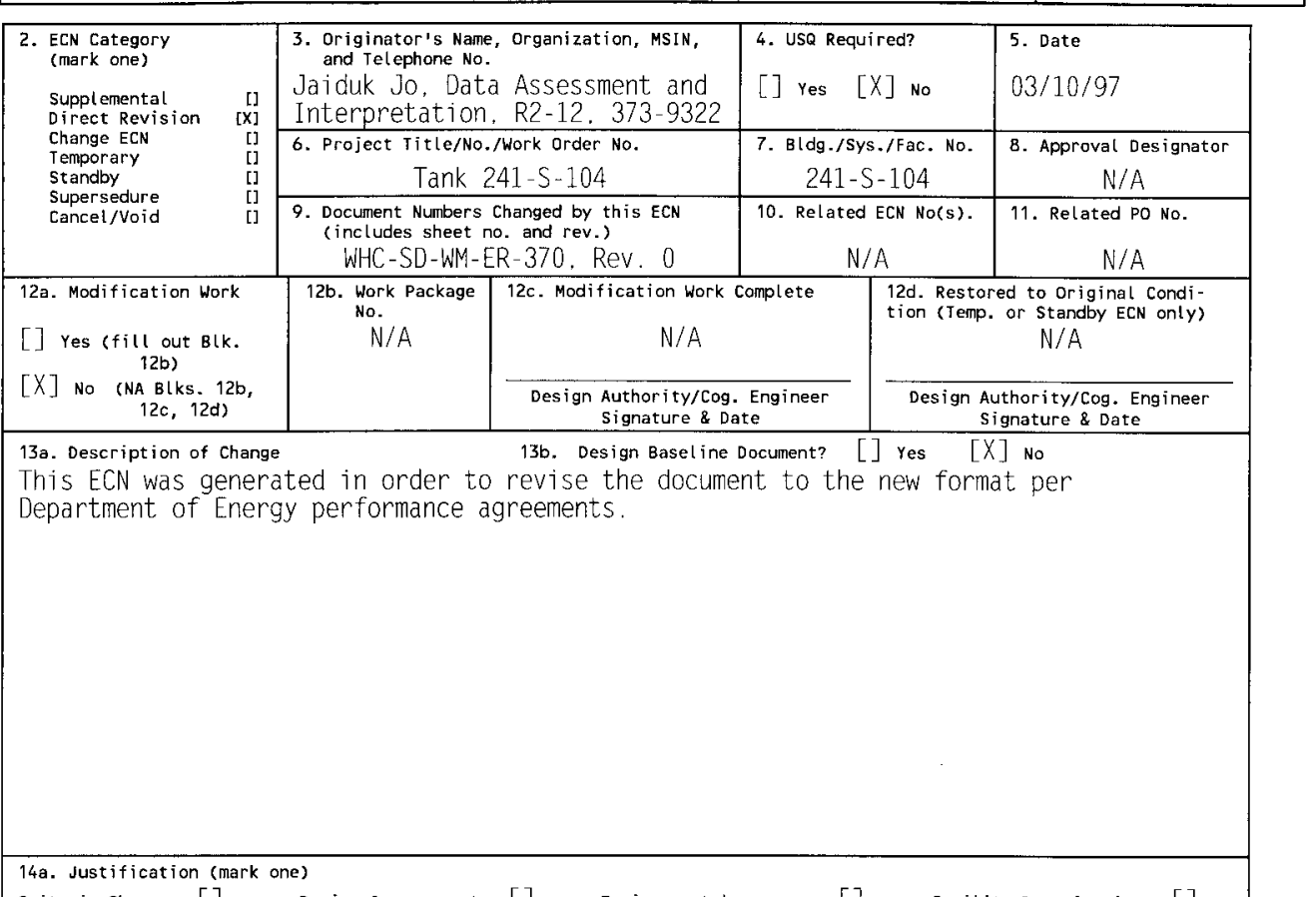

14a. Justification (mark one)

$\begin{array}{llllllll}\text { Criteria Change } & {[]} & \text { Design Improvement } & {[]} & \text { Environmental } & {[]} & \text { Facility Deactivation } & {[]} \\ \text { As-Found } & {[X]} & \text { Facilitate Const } & {[]} & \text { Const. Error/Omission } & {[]} & \text { Design Error/Omission } & {[]}\end{array}$

14b. Justification Details

This document was revised per Department of Energy performance agreenents and direction from the Washington State Department of Ecology to revise 23 tank characterization reports (letter dated $7 / 6 / 95$ ).

15. Distribution (include name, MSIN, and no. of copies) See attached distribution.

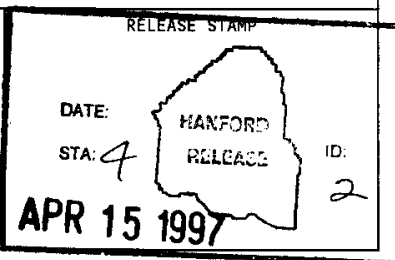




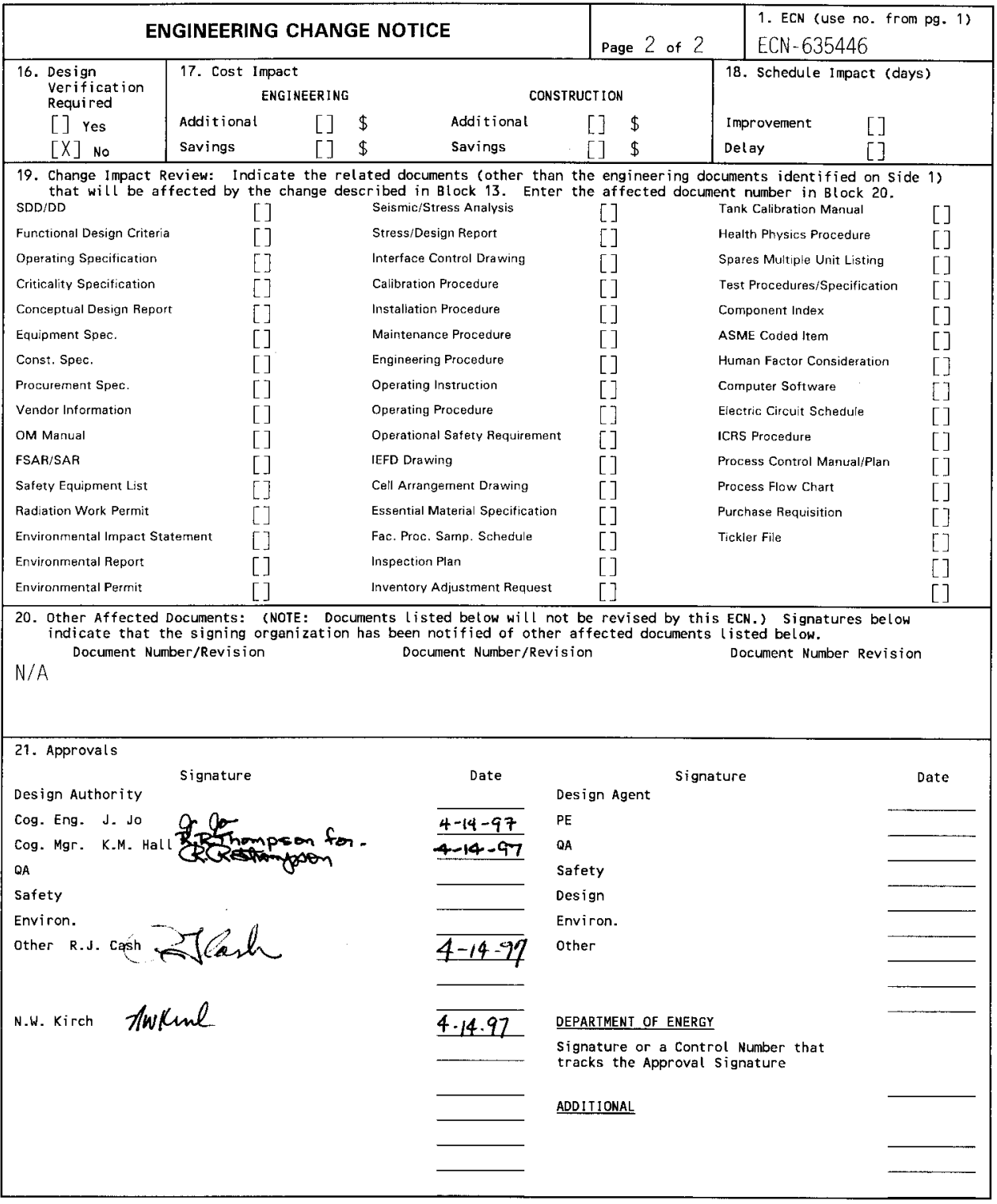




\section{Tank Characterization Report for Single-Shell Tank 241-S-104}

Jaiduk Jo

Lockheed Martin Hanford Corp. . Richland, WA 99352

U.S. Department of Energy Contract DE-AC06-87RL10930

EDT/ECN: $\quad$ ECN-635446 UC: 2070

Org Code: $74620 \quad$ Charge Code: N4G4C

B\&R Code: EW 3120074 Tota1 Pages: 2,4

Key Words: Waste Characterization, Single-She11 Tank. SST. Tank 241-S104. Tank S-104, S-104, S Farm, Tank Characterization Report, TCR, Waste Inventory. TPA Milestone M-44

Abstract: This document summarizes the information on the historical uses. present status, and the sampling and analysis results of waste stored in Tank 241-S-104. This report supports the requirements of the Tri-Party Agreement Milestone M-44-05.

TRADEMARK DISCLAIMER. Reference herein to any specific comercial product, process, or service by trade name, trademark, manufacturer, or otherwise, does not necessarily constitute or imply its endorsement, recommendation, or favoring by the United States Government or any agency thereof or its contractors or subcontractors.

Printed in the United states of America. To obtain copies of this document, contact: WHC/BCS Document Control Services, P.O. Box 1970, Mailstop H6-08, Richland WA 99352, Phone (509) 372-2420; Fax (509) 376-4989.
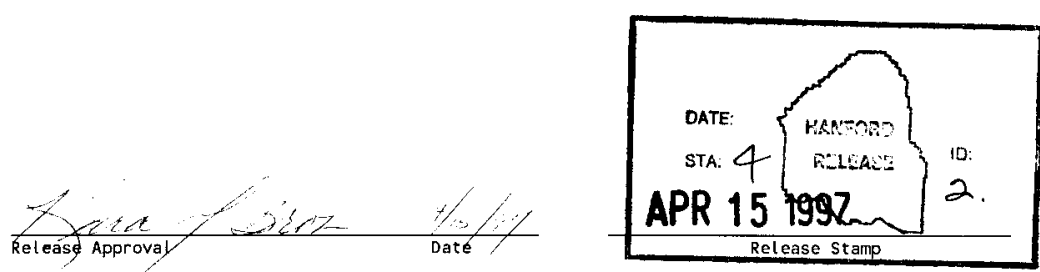

\section{Approved for Public Release}




\section{RECORD OF REVISION}

(2) Title

Tank Characterization Report for Single-Shel1 Tank 241-S-104

CHANGE CONTROL RECORD

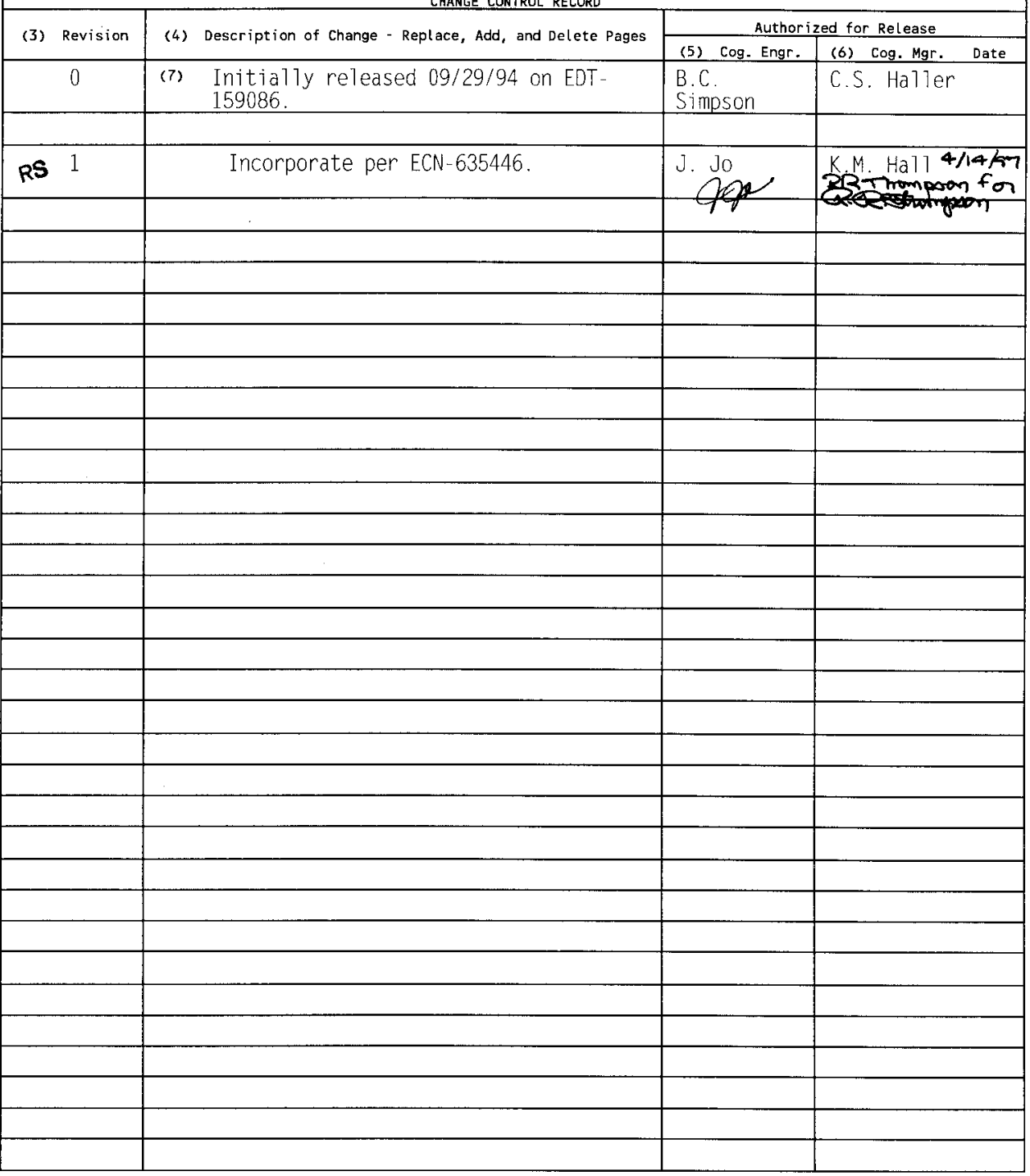




\section{Tank Characterization Report for Single-Shell Tank 241-S-104}

J. Jo

Lockheed Martin Hanford Corporation

R. D. Cromar

Numatec Hanford Corporation

R. T. Winward

Meier Associates

Date Published

April 1997

Prepared for the U.S. Department of Energy

Assistant Secretary for Environmental Management

Project Hanford Management Contractor for the

U.S. Department of Energy under Contract DE-AC06-96RL13200

Approved for public release; distribution is unlimited 


\section{CONTENTS}

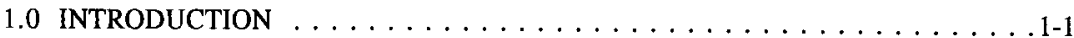

1.1 SCOPE

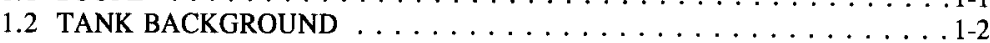

2.0 RESPONSE TO TECHNICAL ISSUES $\ldots \ldots \ldots \ldots \ldots \ldots \ldots \ldots \ldots \ldots \ldots$

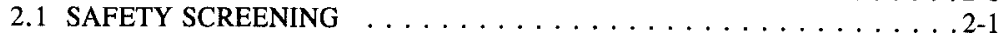

2.1.1 Exothermic Conditions (Energetics) $\ldots \ldots \ldots \ldots \ldots \ldots \ldots .1$

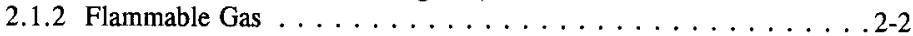

2.1 .3 Criticality $\ldots \ldots \ldots \ldots \ldots \ldots \ldots \ldots \ldots \ldots \ldots \ldots \ldots \ldots \ldots \ldots .2-2$

2.2 OTHER TECHNICAL ISSUES $\ldots \ldots \ldots \ldots \ldots \ldots \ldots \ldots \ldots \ldots \ldots \ldots \ldots \ldots \ldots .2-2$

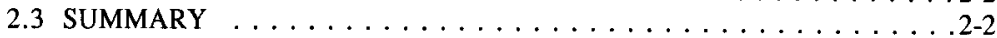

3.0 BEST-BASIS STANDARD INVENTORY ESTIMATE $\ldots \ldots \ldots \ldots$. $\ldots \ldots$

4.0 RECOMMENDATIONS $\ldots \ldots \ldots \ldots \ldots \ldots \ldots \ldots \ldots \ldots . \ldots . \ldots .1$

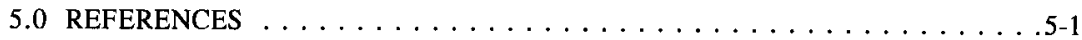

APPENDIXES

APPENDIX A: HISTORICAL TANK INFORMATION $\ldots \ldots \ldots \ldots \ldots \ldots \ldots$ A-1

A1.0 CURRENT TANK STATUS $\ldots \ldots \ldots \ldots \ldots \ldots \ldots \ldots$ A-3

A2.0 TANK DESIGN AND BACKGROUND $\ldots \ldots \ldots \ldots \ldots \ldots \ldots$ A-4

A3.0 PROCESS KNOWLEDGE $\ldots \ldots \ldots \ldots \ldots \ldots \ldots \ldots \ldots \ldots$ A $\ldots \ldots$

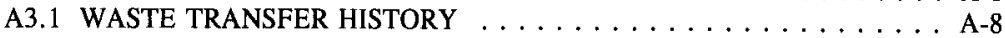

A3.2 HISTORICAL ESTIMATION OF TANK CONTENTS . . . . . . A A-10

A4.0 SURVEILLANCE DATA . . . . . . . . . . . . . . . . A-14

A4.1 SURFACE-LEVEL READINGS $\ldots \ldots \ldots \ldots \ldots \ldots \ldots \ldots$ A-14

A4.2 INTERNAL TANK TEMPERATURES $\ldots \ldots \ldots \ldots \ldots \ldots \ldots$ A-14

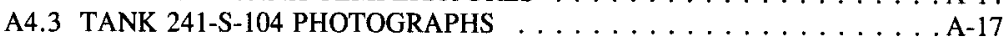

A5.0 APPENDIX A REFERENCES . . . . . . . . . . . . . . . . A-19 


\section{CONTENTS (Continued)}

APPENDIX B: SAMPLING OF TANK $241-\mathrm{S}-104 \ldots \ldots \ldots \ldots \ldots$. . . . .

B1.0 TANK SAMPLING OVERVIEW $\ldots \ldots \ldots \ldots \ldots \ldots \ldots \ldots$ B-3

B1.1 DESCRIPTION OF SAMPLING EVENT $\ldots \ldots \ldots \ldots \ldots \ldots \ldots \ldots$ B-3

B1.2 SAMPLE HANDLING $\ldots \ldots \ldots \ldots \ldots \ldots \ldots \ldots \ldots \ldots$ B-5

B1.3 SAMPLE ANALYSES $\ldots \ldots \ldots \ldots \ldots \ldots \ldots \ldots \ldots \ldots \ldots \ldots$

B1.3.1 Sample Preparation $\ldots \ldots \ldots \ldots \ldots \ldots \ldots \ldots \ldots \ldots$

B1.3.2 Analytical Methods . . . . . . . . . . . . B-13

B1.3.3 Physical and Rheological Tests . . . . . . . . . . B-16

B1.3.4 Chemical and Radionuclide Constituent Analysis . . . . . . B-16

B1.3.5 Organic Constituent Analysis . . . . . . . . . . B-17

B1.4 DESCRIPTION OF HISTORICAL SAMPLING EVENT . . . . . . . B-17

B2.0 ANALYTICAL RESULTS $\ldots \ldots \ldots \ldots \ldots \ldots \ldots \ldots \ldots \ldots$ B-18

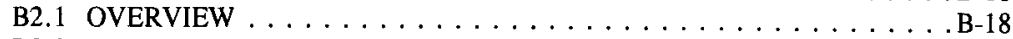

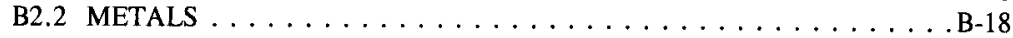

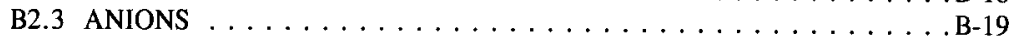

B2.4 RADIONUCLIDES $\ldots \ldots \ldots \ldots \ldots \ldots \ldots \ldots \ldots \ldots \ldots \ldots$

B2.4.1 Alpha Activity $\ldots \ldots \ldots \ldots \ldots \ldots \ldots \ldots \ldots \ldots \ldots$

B2.4.2 Mass Spectrometry $\ldots \ldots \ldots \ldots \ldots \ldots \ldots \ldots$

B2.4.3 Total Beta Activity . . . . . . . . . . . . . B-19

B2.4.4 Gamma Energy Analysis . . . . . . . . . . . B-20

B2.4.5 Liquid Scintillation Counting $\ldots \ldots \ldots \ldots \ldots \ldots \ldots$ B-20

B2.5 PHYSICAL ANALYSES $\ldots \ldots \ldots \ldots \ldots \ldots \ldots \ldots \ldots \ldots \ldots$

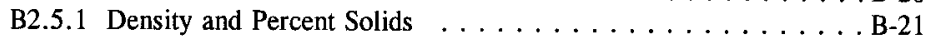

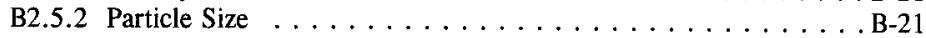

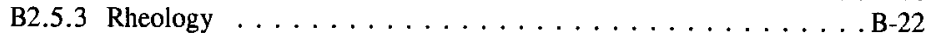

B2.5.4 Thermogravimetric Analysis . . . . . . . . . . B-24

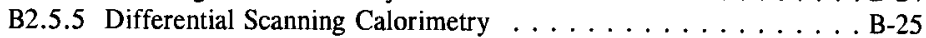

B2.6 ORGANIC CONSTITUENTS $\ldots \ldots \ldots \ldots \ldots \ldots \ldots \ldots \ldots$ B-25

B2.7 VAPOR PHASE MEASUREMENT $\ldots \ldots \ldots \ldots \ldots \ldots \ldots \ldots$ B-25

B2.8 HISTORICAL SAMPLE RESULTS $\ldots \ldots \ldots \ldots \ldots \ldots \ldots \ldots \ldots$ B-26

B2.9 ANALYTICAL DATA TABLES $\ldots \ldots \ldots \ldots \ldots \ldots \ldots \ldots$ B-28

B3.0 ASSESSMENT OF CHARACTERIZATION RESULTS $\ldots \ldots \ldots \ldots \ldots$. . . . . 113

B3.1 FIELD OBSERVATIONS $\ldots \ldots \ldots \ldots \ldots \ldots \ldots \ldots \ldots \ldots \ldots$

B3.2 QUALITY CONTROL ASSESSMENT $\ldots \ldots \ldots \ldots \ldots \ldots \ldots$ B-114

B3.3 DATA VALIDATION FINDINGS $\ldots \ldots \ldots \ldots \ldots \ldots \ldots \ldots \ldots$ B-114

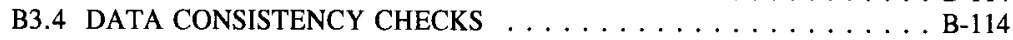

B3.4.1 Comparison of Results from Different Analytical Methods ... B-115

B3.4.2 Mass and Charge Balance .............. B-116 


\section{CONTENTS (Continued)}

B3.5 MEAN CONCENTRATIONS AND CONFIDENCE INTERVALS . . B-119 B3.5.1 Composite Means . . . . . . . . . . . . . . . B-119

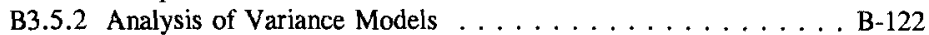

B3.5.3 Inventory $\ldots \ldots \ldots \ldots \ldots \ldots \ldots \ldots \ldots \ldots \ldots$

B4.0 APPENDIX B REFERENCES $\ldots \ldots \ldots \ldots \ldots \ldots \ldots \ldots \ldots \ldots$ B-126

APPENDIX C: STATISTICAL ANALYSIS FOR ISSUE RESOLUTION $\ldots \ldots \ldots$ C-1

C1.0 STATISTICS FOR SAFETY SCREENING DQO $\ldots \ldots \ldots \ldots \ldots \ldots$ C-3

C2.0 APPENDIX C REFERENCE . . . . . . . . . . . . C-4

APPENDIX D: RESULTS OF THE EVALUATION TO ESTABLISH BEST-BASIS STANDARD INVENTORY FOR TANK $241-S-104 \ldots \ldots \ldots$ D-1

D1.0 CHEMICAL INFORMATION SOURCES $\ldots \ldots \ldots \ldots \ldots \ldots$ D-3

D2.0 COMPARISON OF COMPONENT INVENTORY VALUES $\ldots \ldots \ldots \ldots$ D-3

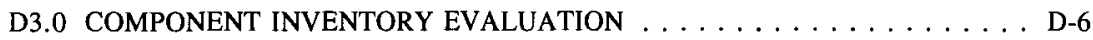

D3.1 EXPECTED TYPE OF WASTE BASED ON THIS ASSESSMENT $\ldots$ D-6

D3.2 ASSUMPTIONS USED FOR THIS ASSESSMENT $\ldots \ldots \ldots \ldots \ldots$ D-7

D3.3 METHODOLOGY USED FOR THIS EVALUATION . . . . . . . . D-7

D3.3.1 Evaluation of Technical Flowsheet Information . . . . . . . D-8

D3.3.2 Evaluation Of Sample Information Sources $\ldots \ldots \ldots \ldots$ D-8

D3.4 INVENTORY COMPARISONS $\ldots \ldots \ldots \ldots \ldots \ldots \ldots \ldots \ldots$ D-10

D4.0 DEFINE THE BEST-BASIS AND ESTABLISH

COMPONENT INVENTORIES $\ldots \ldots \ldots \ldots \ldots \ldots \ldots \ldots \ldots \ldots \ldots \ldots$

D5.0 APPENDIX D REFERENCES $\ldots \ldots \ldots \ldots \ldots \ldots \ldots \ldots \ldots \ldots \ldots$

APPENDIX E: BIBLIOGRAPHY FOR TANK $241-S-104 \ldots \ldots \ldots \ldots \ldots \ldots$ E-1 


\section{LIST OF FIGURES}

A2-1 Tank 241-S-104 Cross Section and Schematic . . . . . . . . . A-5

A2-2 Riser Configuration for Tank $241-S-104 \ldots \ldots \ldots \ldots \ldots$ A-6

A3-1 Tank Layer Model $\ldots \ldots \ldots \ldots \ldots \ldots \ldots \ldots \ldots \ldots$ A-11

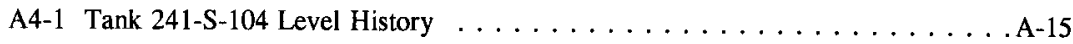

A4-2 Tank 241-S-104 High Temperature Plot $\ldots \ldots \ldots \ldots \ldots \ldots \ldots$. . . . . .

\section{LIST OF TABLES}

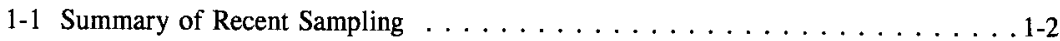

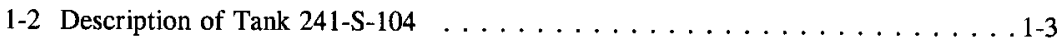

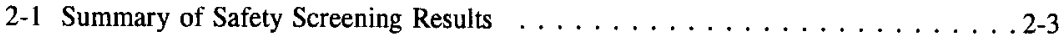

3-1 Best-Basis Inventory Estimates for Nonradioactive Components in Tank 241-S-104 (December 4, 1996) . . . . . . . . . . . . . . . . 3-2

3-2 Best-Basis Inventory Estimates for Radioactive Components in Tank 241-S-104 (December 4, 1996) . . . . . . . . . . . . . . . 3-3

4-1 Acceptance of Tank 241-S-104 Sampling and Analysis . . . . . . . . . 4-1

4-2 Acceptance of Evaluation of Characterization Data and Information for Tank $241-\mathrm{S}-104 \ldots \ldots \ldots \ldots \ldots \ldots \ldots$. . . . . . . . .

A1-1 Tank Contents Status Summary $\ldots \ldots \ldots \ldots \ldots \ldots \ldots$ A-4

A2-1 Tank 241-S-104 Risers $\ldots \ldots \ldots \ldots \ldots \ldots \ldots \ldots \ldots \ldots$. . . . . .

A3-1 Tank 241-S-104 Major Transfers . . . . . . . . . . . . . A A-9

A3-2 Historical Tank Inventory Estimate $\ldots \ldots \ldots \ldots \ldots \ldots \ldots \ldots \ldots \ldots \ldots \ldots \ldots$ 


\section{LIST OF TABLES (Continued)}

B1-1 Tank 241-S-104 Sample Numbers and Locations $\ldots \ldots \ldots \ldots \ldots \ldots$ B-4

B1-2 Sample and Extrusion Information for $241-S-104 \ldots \ldots \ldots \ldots$ B-6

B1-3 Tank 241-S-104 Composite and Liquid Tracking Numbers

from the $222-S$ Laboratory . . . . . . . . . . . . . . . . . B-11

B1-4 Tank 241-S-104 Sample Numbers from Pacific Northwest Laboratory . . . . B-11

B1-5 Tank 241-S-104 Samples and Requested Analytes . . . . . . . . . . . B-13

B1-6 Analytical Methods for Physical and Rheological Tests . . . . . . . . . B-14

B1-7 Analytical Methods for Chemical and Radiochemical Analyses . . . . . . . . B-14

B1-8 Analytical Methods for Organic Analyses . . . . . . . . . . B-16

B2-1 Analytical Data Presentation Tables $\ldots \ldots \ldots \ldots \ldots \ldots \ldots \ldots$ B-18

B2-2 Tank 241-S-104, Core 42 Physical Measurements $\ldots \ldots \ldots \ldots \ldots \ldots$. . . . . .

B2-3 Summary of Particle Size Distribution for Tank 241-S-104 . . . . . . B-21

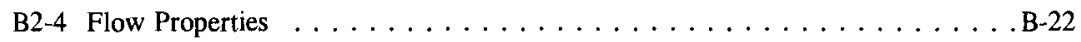

B2-5 Power Law Curve Fit Parameters $\ldots \ldots \ldots \ldots \ldots \ldots \ldots \ldots$. . . . . . . .

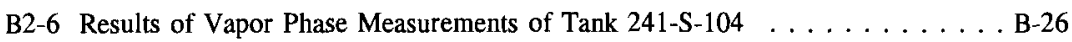

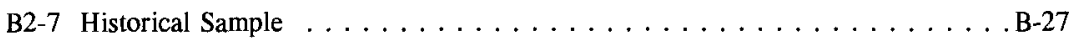

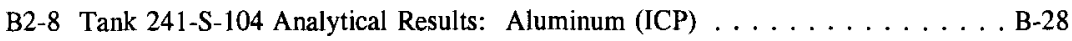

B2-9 Tank 241-S-104 Analytical Results: Antimony (ICP) . . . . . . . . B-30

B2-10 Tank 241-S-104 Analytical Results: Arsenic (ICP) . . . . . . . . . B-31

B2-11 Tank 241-S-104 Analytical Results: Arsenic (Atomic Absorption) . . . . . . B-33

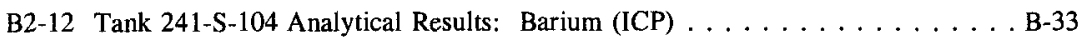

B2-13 Tank 241-S-104 Analytical Results: Beryllium (ICP) $\ldots \ldots \ldots \ldots \ldots$. . . . . . 


\section{LIST OF TABLES (Continued)}

B2-14 Tank 241-S-104 Analytical Results: Bismuth (ICP) . . . . . . . . . . B-36

B2-15 Tank 241-S-104 Analytical Results: Boron (ICP) $\ldots \ldots \ldots \ldots \ldots$. . . . . . . .

B2-16 Tank 241-S-104 Analytical Results: Cadmium (ICP) . . . . . . . . . B-40

B2-17 Tank 241-S-104 Analytical Results: Calcium (ICP) $\ldots \ldots \ldots \ldots \ldots$. . . . . . .

B2-18 Tank 241-S-104 Analytical Results: Cerium (ICP) . . . . . . . . . . . B-43

B2-19 Tank 241-S-104 Analytical Results: Chromium (ICP) . . . . . . . . . . B-44

B2-20 Tank 241-S-104 Analytical Results: Hexavalent Chromium $(\mathrm{Cr}+6) \ldots \ldots$. . B-46

B2-21 Tank 241-S-104 Analytical Results: Cobalt (ICP) . . . . . . . . . . . . . . B-46

B2-22 Tank 241-S-104 Analytical Results: Copper (ICP) . . . . . . . . . . . . . B-47

B2-23 Tank 241-S-104 Analytical Results: Iron (ICP) . . . . . . . . . . . . B-49

B2-24 Tank 241-S-104 Analytical Results: Lanthanum (ICP) . . . . . . . . . . B-51

B2-25 Tank 241-S-104 Analytical Results: Lead (ICP) . . . . . . . . . . . B-52

B2-26 Tank 241-S-104 Analytical Results: Magnesium (ICP) $\ldots \ldots \ldots \ldots \ldots \ldots$. . . . . .

B2-27 Tank 241-S-104 Analytical Results: Manganese (ICP) $\ldots \ldots \ldots \ldots$. . . . . . .

B2-28 Tank 241-S-104 Analytical Results: Mercury (CVAA) . . . . . . . . . B-57

B2-29 Tank 241-S-104 Analytical Results: Nickel (ICP) . . . . . . . . . . . B-57

B2-30 Tank 241-S-104 Analytical Results: Phosphorus (ICP) . . . . . . . . . . B-58

B2-31 Tank 241-S-104 Analytical Results: Potassium (ICP) $\ldots \ldots \ldots \ldots$. . . . . B-60

B2-32 Tank 241-S-104 Analytical Results: Selenium (ICP) $\ldots \ldots \ldots \ldots \ldots$. . . . .

B2-33 Tank 241-S-104 Analytical Results: Selenium (Atomic Absorption) . . . . . B-63

B2-34 Tank 241-S-104 Analytical Results: Silicon (ICP) . . . . . . . . . . . . B-63 


\section{LIST OF TABLES (Continued)}

B2-35 Tank 241-S-104 Analytical Results: Silver (ICP) . . . . . . . . . . . . B-65

B2-36 Tank 241-S-104 Analytical Results: Sodium (ICP) $\ldots \ldots \ldots \ldots$. . . . B-66

B2-37 Tank 241-S-104 Analytical Results: Strontium (ICP) $\ldots \ldots \ldots \ldots$. . . . . . .

B2-38 Tank 241-S-104 Analytical Results: Sulfur (ICP) $\ldots \ldots \ldots \ldots$. . . . . . B-69

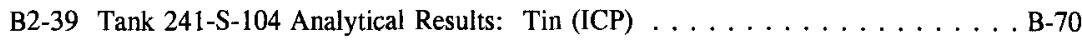

B2-40 Tank 241-S-104 Analytical Results: Titanium (ICP) . . . . . . . . . . . B-71

B2-41 Tank 241-S-104 Analytical Results: Zinc (ICP) $\ldots \ldots \ldots \ldots \ldots \ldots$. . . . . .

B2-42 Tank 241-S-104 Analytical Results: Zirconium (ICP) . . . . . . . . . . . B-75

B2-43 Tank 241-S-104 Analytical Results: Ammonium (Distillation (NH3). . . . . B B-76

B2-44 Tank 241-S-104 Analytical Results: Ammonium (Distillation) . . . . . . . B-76

B2-45 Tank 241-S-104 Analytical Results: Carbonate (TIC) . . . . . . . . . B-77

B2-46 Tank 241-S-104 Analytical Results: Chloride (IC) . . . . . . . . . . . . B-77

B2-47 Tank 241-S-104 Analytical Results: Cyanide . . . . . . . . . . . B-78

B2-48 Tank 241-S-104 Analytical Results: Fluoride (IC) $\ldots \ldots \ldots \ldots \ldots$. . . . . . .

B2-49 Tank 241-S-104 Analytical Results: Hydroxide (OH Automatic) . . . . . . . B-79

B2-50 Tank 241-S-104 Analytical Results: Nitrate (IC) $\ldots \ldots \ldots \ldots \ldots \ldots$. . . . . . .

B2-51 Tank 241-S-104 Analytical Results: Nitrite (IC) $\ldots \ldots \ldots \ldots \ldots \ldots$. . . . . .

B2-52 Tank 241-S-104 Analytical Results: Nitrite (Spectrophotometric) . . . . . . B-81

B2-53 Tank 241-S-104 Analytical Results: Phosphate (IC) . . . . . . . . . . B-82

B2-54 Tank 241-S-104 Analytical Results: Sulfate (IC) . . . . . . . . . . B-83

B2-55 Tank 241-S-104 Analytical Results: Americium-241 (GEA) . . . . . . . . B-84 


\section{LIST OF TABLES (Continued)}

B2-56 Tank 241-S-104 Analytical Results: Americium-241 (Alpha Spectrometry) . . B-85

B2-57 Tank 241-S-104 Analytical Results: Carbon-14 . . . . . . . . . . . . . . B-85

B2-58 Tank 241-S-104 Analytical Results: Cesium-137 (GEA) . . . . . . . . . . B-86

B2-59 Tank 241-S-104 Analytical Results: Cobalt-60 (GEA) $\ldots \ldots \ldots \ldots$. . . . B-87

B2-60 Tank 241-S-104 Analytical Results: Europium-154 (GEA) . . . . . . . . . . B-87

B2-61 Tank 241-S-104 Analytical Results: Europium-155 (GEA) . . . . . . . . . . B-88

B2-62 Tank 241-S-104 Analytical Results: Iodine-129 . . . . . . . . . . . . . . B-89

B2-63 Tank 241-S-104 Analytical Results: Neptunium-237 . . . . . . . . . . . . . B-89

B2-64 Tank 241-S-104 Analytical Results: Plutonium-238

(Alpha Spectrometry) . . . . . . . . . . . . . . . . . . . . B-90

B2-65 Tank 241-S-104 Analytical Results: Plutonium-238 to Plutonium Ratio (Mass Spectrometry) . . . . . . . . . . . . . . . . . . B-90

B2-66 Tank 241-S-104 Analytical Results: Plutonium-239/40 (Alpha Spectrometry) . . . . . . . . . . . . . . . . . . . . . . B-91

B2-67 Tank 241-S-104 Analytical Results: Plutonium-239 to Plutonium Ratio (Mass Spectrometry) . . . . . . . . . . . . . B-91

B2-68 Tank 241-S-104 Analytical Results: Plutonium-240 to Plutonium Ratio (Mass Spectrometry) . . . . . . . . . . . . . . . . . . B-92

B2-69 Tank 241-S-104 Analytical Results: Plutonium-241 to Plutonium Ratio (Mass Spectrometry) . . . . . . . . . . . . . . . . B-92

B2-70 Tank 241-S-104 Analytical Results: Plutonium-242 to Plutonium Ratio (Mass Spectrometry) . . . . . . . . . . . . . . B-93

B2-71 Tank 241-S-104 Analytical Results: Selenium-79 . . . . . . . . . . . B B-93

B2-72 Tank 241-S-104 Analytical Results: Strontium-90 . . . . . . . . . . . . B-94

B2-73 Tank 241-S-104 Analytical Results: Technetium-99 . . . . . . . . . . . . B-94 


\section{LIST OF TABLES (Continued)}

B2-74 Tank 241-S-104 Analytical Results: Tritium (Liquid Scintillation) . . . . . B B-95

B2-75 Tank 241-S-104 Analytical Results: Uranium-234 to Uranium Ratio (Mass Spectrometry) . . . . . . . . . . . . . . . . . . . . . B-95

B2-76 Tank 241-S-104 Analytical Results: Uranium-235 to Uranium Ratio (Mass Spectrometry) . . . . . . . . . . . . . . . . . . B-96

B2-77 Tank 241-S-104 Analytical Results: Uranium-236 to Uranium Ratio (Mass Spectrometry) . . . . . . . . . . . . . . . . . B-96

B2-78 Tank 241-S-104 Analytical Results: Uranium-238 to Uranium Ratio (Mass Spectrometry) . . . . . . . . . . . . . . . . . . . B-97

B2-79 Tank 241-S-104 Analytical Results: Total Alpha . . . . . . . . . . . . . . . B-97

B2-80 Tank 241-S-104 Analytical Results: Total Alpha Plutonium . . . . . . . . . B-98

B2-81 Tank 241-S-104 Analytical Results: Ratio of Total Alpha to Plutonium + Americium $\ldots \ldots \ldots \ldots \ldots \ldots \ldots$ B-98

B2-82 Tank 241-S-104 Analytical Results: Total Beta (Alpha Radiation) . . . . . . B-99

B2-83 Tank 241-S-104 Analytical Results: Total Beta . . . . . . . . . . . . . . . . B-99

B2-84 Tank 241-S-104 Analytical Results: Ratio of Total Beta to Cesium + Strontium $\ldots \ldots \ldots \ldots \ldots \ldots \ldots \ldots$. . $\ldots \ldots 9$

B2-85 Tank 241-S-104 Analytical Results: Percent Water (TGA) . . . . . . . . B-100

B2-86 Tank 241-S-104 Analytical Results: Percent Water (Percent Solids) . . . . . . . . . . . . . . . . . . . B-101

B2-87 Differential Scanning Calorimetry (DSC) $\ldots \ldots \ldots \ldots \ldots \ldots$ B-102

B2-88 Tank 241-S-104 Analytical Results: pH Measurement . . . . . . . . . B-104

B2-89 Tank 241-S-104 Analytical Results: Total Organic Carbon (Furnace Oxidation) . . . . . . . . . . . . . . . B-104

B2-90 Tank 241-S-104 Analytical Results: Total Organic Carbon (Furnace Oxidation) . . . . . . . . . . . . . . . . . B-105 


\section{LIST OF TABLES (Continued)}

B2-91 Tank 241-S-104 Analytical Results: Specific Gravity . . . . . . . . . . B-105

B2-92 Tank 241-S-104 Analytical Results: Centrifuged Solids Density . . . . . B-105

B2-93 Tank 241-S-104 Analytical Results: Centrifuged

Supernatant Density . . . . . . . . . . . . . . . . . . B-105

B2-94 Tank 241-S-104 Analytical Results: Density . . . . . . . . . . . . B-106

B2-95 Tank 241-S-104 Analytical Results: Settled Solids . . . . . . . . . . . B-106

B2-96 Tank 241-S-104 Analytical Results: Volume Percent

Centrifuged Solids . . . . . . . . . . . . . . . B-106

B2-97 Tank 241-S-104 Analytical Results: Weight Percent

Centrifuged Solids . . . . . . . . . . . . . . . . B-106

B2-98 Tank 241-S-104 Analytical Results: Weight Percent Solids . . . . . . . . B-107

B2-99 Tank 241-S-104 Analytical Results: Weight Percent Undissolved Solids . . . . . . . . . . . . . . . . . B-107

B2-100 Tank 241-S-104 Analytical Results: Extractible Organic Halides . . . . . . B-107

B2-101 Tank 241-S-104 Analytical Data: Volatile Organic Analyses . . . . . . . B-108

B2-102 Tank 241-S-104 Analytical Results: Dodecane (VOA) . . . . . . . . . . B-109

B2-103 Tank 241-S-104 Analytical Results: Hexamethyl Disiloxane (VOA) . . . . B B-109

B2-104 Tank 241-S-104 Analytical Results: Methoxytrimethyl Silane (VOA) . . . . B-110

B2-105 Tank 241-S-104 Analytical Results: Trimethyl Silanol (VOA) . . . . . . B-110

B2-106 Tank 241-S-104 Analytical Data: Semivolatile

Organic Analyses (SVOA) . . . . . . . . . . . . . B-111

B2-107 Tank 241-S-104 Analytical Results: Dodecane (SVOA) . . . . . . . . B-112

B2-108 Tank 241-S-104 Analytical Results: Pentadecane (SVOA) . . . . . . . B-112

B2-109 Tank 241-S-104 Analytical Results: Tetradecane (SVOA) . . . . . . . . B-112 


\section{LIST OF TABLES (Continued)}

B2-110 Tank 241-S-104 Analytical Results: Tridecane (SVOA) . . . . . . . . B B-113

B3-1 Tank 241-S-104 Comparison of Gross Beta Activities with the

Total of the Individual Activities . . . . . . . . . . . . . B-116

B3-2 Tank 241-S-104 Comparison of Gross Alpha Activities with the Total of the Individual Activities . . . . . . . . . . . . . B-116

B3-3 Cation Mass and Charge Data . . . . . . . . . . . . B-118

B3-4 Anion Mass and Charge Data $\ldots \ldots \ldots \ldots \ldots \ldots$ B-118

B3-5 Mass Balance Totals $\ldots \ldots \ldots \ldots \ldots \ldots \ldots \ldots \ldots$ B-118

B3-6 95 Percent Two-Sided Confidence Interval for the Mean

Concentration for Composite Sample Data . . . . . . . . . . . B-120

B3-7 Analytical-Based Inventory for Composite Sample Data for Tank $241-S-104 \ldots \ldots \ldots \ldots \ldots \ldots$. . . . . . . . . . . . B-124

C1-1 95 Percent Confidence Interval Upper Limits for Total Alpha for Tank $241-S-104 \ldots \ldots \ldots \ldots \ldots$. . . . . . . .

D2-1 Sampling-Based and Hanford Defined Waste-Based Inventory Estimates for Nonradioactive Components in Tank 241-S-104 . . . . . . . . . . . . D-4

D2-2 Sampling and HDW Model Predicted Inventory Estimates for Radioactive Components in Tank 241-S-104 (Radionuclides degraded to February 1994) . D D-5

D3-1 Technical Process Flowsheet and Los Alamos National Laboratory Defined Waste Streams . . . . . . . . . . . . . . D-8

D3-2 Concentrations of Components in REDOX Process Sludges and 241-S-104 Inventory Calculations . . . . . . . . . . . . D D-9

D3-3 Comparison of Selected Component Inventory Estimates for Tank $241-\mathrm{S}-104$ Waste. . . . . . . . . . . . . . . . D-11 


\section{LIST OF TABLES (Continued)}

D4-1 Best-Basis Inventory Estimates for Nonradioactive Components

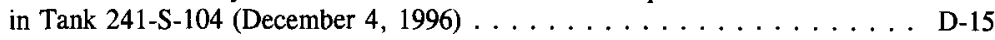

D4-2 Best-Basis Inventory Estimates for Radioactive Components in Tank 241-S-104 (Radionuclides decayed to January 1, 1994) (December 4, 1996) . . . . . . . . . . . . . . . . . . . D-16 


\section{LIST OF TERMS}

\begin{tabular}{|c|c|}
\hline AEA & alpha energy analysis \\
\hline ANOVA & analysis of variance \\
\hline $\mathrm{Btu} / \mathrm{hr}$ & British thermal units per hour \\
\hline $\mathrm{Ci}$ & curies \\
\hline $\mathrm{Ci} / \mathrm{L}$ & curies per liter \\
\hline CVAA & cold vapor atomic absorption spectrometry \\
\hline $\mathrm{cm}$ & centimeter \\
\hline CWR & REDOX cladding waste \\
\hline CWR1 & REDOX cladding waste $1952-60$ \\
\hline df & degrees of freedom \\
\hline DQO & data quality objectives \\
\hline DSC & differential scanning calorimetry \\
\hline $\mathrm{ft}$ & feet \\
\hline $\mathrm{ft} / \mathrm{sec}$ & feet per second \\
\hline $\mathrm{g}$ & gram \\
\hline $\mathrm{gal} / \mathrm{min}$ & gallons per minute \\
\hline GEA & gamma energy analysis \\
\hline $\mathrm{g} / \mathrm{cm}^{3}$ & grams per cubic centimeter \\
\hline $\mathrm{g} / \mathrm{L}$ & grams per liter \\
\hline $\mathrm{g} / \mathrm{mL}$ & grams per milliliter \\
\hline HDW & Hanford defined waste \\
\hline IC & ion chromatography \\
\hline ICP & inductively coupled plasma spectroscopy \\
\hline in. & inch \\
\hline $\mathrm{J} / \mathrm{g}$ & joules per gram \\
\hline $\mathrm{kg}$ & kilogram \\
\hline $\mathrm{kg} / \mathrm{L}$ & kilograms per liter \\
\hline kgal & kilogallon \\
\hline $\mathrm{kL}$ & kiloliter \\
\hline $\mathrm{kW}$ & kilowatt \\
\hline $\mathrm{L}$ & liter \\
\hline $\mathrm{L} / \mathrm{min}$ & liters per minute \\
\hline LEL & lower explosive limit \\
\hline LL & lower limit \\
\hline $\mathrm{m}$ & meter \\
\hline$M$ & moles per liter \\
\hline $\mathrm{mL}$ & milliliters \\
\hline $\mathrm{mL} / \mathrm{L}$ & milliliters per liter \\
\hline $\mathrm{mm}$ & millimeter \\
\hline $\mathrm{m} / \mathrm{sec}$ & meters per second \\
\hline
\end{tabular}




\section{LIST OF TERMS (Continued)}

\begin{tabular}{|c|c|}
\hline $\mathrm{n} / \mathrm{a}$ & not applicable \\
\hline $\mathrm{n} / \mathrm{d}$ & not detected \\
\hline $\mathrm{n} / \mathrm{r}$ & not reported \\
\hline $\mathrm{OH}$ & free hydroxide \\
\hline $\mathrm{Pa}$ & pascals \\
\hline Pa sec & pascal seconds \\
\hline ppm & parts per million \\
\hline ppmv & parts per million volume \\
\hline $\mathrm{pH}$ & hydrogen potential \\
\hline PHMC & Project Hanford Management Contractor \\
\hline QC & quality control \\
\hline $\mathbf{R}$ & REDOX (used to denote various REDOX wastes) \\
\hline $\mathrm{R} 1$ & REDOX waste $1952-57$ \\
\hline $\mathrm{R} 2$ & REDOX waste $1958-66$ \\
\hline REDOX & reduction and oxidation \\
\hline RSltCk & REDOX saltcake \\
\hline SMM & supernatant mixing model \\
\hline SpG & specific gravity \\
\hline SVOA & semivolatile organic analysis \\
\hline TCR & tank characterization report \\
\hline TGA & thermogravimetric analysis \\
\hline TIC & total inorganic carbon \\
\hline TLM & tank layer model \\
\hline TOC & total organic carbon \\
\hline TWRS & Tank Waste Remediation System \\
\hline UL & upper limit \\
\hline VOA & volatile organic analysis \\
\hline $\mathrm{W}$ & watts \\
\hline WSTRS & waste status and transaction record summary \\
\hline wt $\%$ & weight percent \\
\hline$\mu \mathrm{Ci} / \mathrm{g}$ & microcuries per gram \\
\hline$\mu \mathrm{Ci} / \mathrm{gal}$ & microcuries per gallon \\
\hline$\mu \mathrm{Ci} / \mathrm{mL}$ & microcuries per milliliter \\
\hline$\mu \mathrm{eq} / \mathrm{g}$ & microequivalents per gram \\
\hline$\mu \mathrm{g}$ & microgram \\
\hline$\mu \mathrm{g} / \mathrm{g}$ & micrograms per gram \\
\hline$\mu \mathrm{g} / \mathrm{L}$ & micrograms per liter \\
\hline$\mu \mathrm{g} / \mathrm{mL}$ & micrograms per milliliter \\
\hline$\mu \mathrm{m}$ & micrometers \\
\hline${ }^{\circ} \mathrm{C}$ & degrees Celsius \\
\hline${ }^{\circ} \mathrm{F}$ & degrees Fahrenheit \\
\hline
\end{tabular}




\subsection{INTRODUCTION}

One of the major functions of the Tank Waste Remediation System (TWRS) is to characterize wastes in support of waste management and disposal activities at the Hanford Site. Analytical data from sampling and analysis, along with other available information about a tank, are compiled and maintained in a tank characterization report (TCR). This report and its appendixes serve as the TCR for single-shell tank 241-S-104. The objectives of this report are: 1) to use characterization data in response to technical issues associated with 241-S-104 waste; and 2) to provide a standard characterization of this waste in terms of a best-basis inventory estimate. The response to technical issues is summarized in Section 2.0, and the best-basis inventory estimate is presented in Section 3.0. Recommendations regarding safety status and additional sampling needs are provided in Section 4.0. Supporting data and information are contained in the appendixes. This report also supports the requirements of the Hanford Federal Facility Agreement and Consent Order (Ecology et al. 1996) milestone M-44-05.

\subsection{SCOPE}

Characterization information presented in this report originated from sample analyses and known historical sources. While only the results of recent sample events will be used to fulfill the requirements of the data quality objectives (DQOs), other information can be used to support (or question) conclusions derived from these results. Historical information for tank 241-S-104, provided in Appendix A, included surveillance information, records pertaining to waste transfers and tank operations, and expected tank contents derived from a process knowledge model.

The 1992 core sampling and 1996 vapor sampling events are described in Table 1-1. Further sampling and analysis data from these events, as well as data from earlier sampling events, are summarized in Appendix B. The sampling and analyses of 1992 core samples were performed in accordance with Winters et al. (1990) (amended by Hill et al. [1991]), and the results were originally reported in Kocher (1993). The statistical analysis and numerical manipulation of data used in issue resolution are reported in Appendix C. Appendix D contains the evaluation to establish the best basis for the inventory estimate, and the statistical analysis performed for this evaluation. A bibliography that resulted from an in-depth literature search of all known information sources applicable to tank 241-S-104 and its respective waste types is contained in Appendix E. The reports listed in Appendix E may be found in the Lockheed Martin Hanford Corporation Tank Characterization Resource Center. 
Table 1-1. Summary of Recent Sampling.

\begin{tabular}{|c|c|c|c|c|}
\hline thimplotorte & 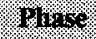 & 18sation & (6.) minnintron. & $8.106014 y$ \\
\hline $\begin{array}{l}\text { Vapor sample } \\
\text { (March 19, 1996) }\end{array}$ & Gas & $\begin{array}{l}\text { Tank headspace, } 6 \mathrm{~m} \\
(20 \mathrm{ft}) \text { below top of } \\
\text { riser }\end{array}$ & $n / a$ & $\mathrm{n} / \mathrm{a}$ \\
\hline $\begin{array}{l}\text { Cores } 42,43, \& 44 \\
\text { (July } 29,1992 \text { to } \\
\text { August } 2,1992 \text { ) }\end{array}$ & Solid & Risers $3,7, \& 2$ & $\begin{array}{l}\text { Segmentation and } \\
\text { composite }\end{array}$ & Good recovery \\
\hline
\end{tabular}

Note:

$$
\text { n/a }=\text { not applicable }
$$

\subsection{TANK BACKGROUND}

Tank 241-S-104, located in the 200 West Area S Tank Farm, was constructed from 1950 to 1951 and went into service in 1953 when it received reduction and oxidation (REDOX) waste from the REDOX Plant. Throughout the service life of the tank, REDOX-process-associated waste made up the majority of the waste received. Tank $241-\mathrm{S}-104$ is the first tank in a cascade with tanks 241-S-105 and 241-S-106 (Brevick et al. 1996). The tank has an operational capacity of $2,870 \mathrm{~kL}(758 \mathrm{kgal})$, and currently contains $1,113 \mathrm{kgal}$ (294 kgal) of non-complexed waste, existing primarily as sludge. Approximately $106 \mathrm{~kL}$ (28 kgal) of drainable interstitial liquid is in the sludge, and $4 \mathrm{~kL}$ (1 kgal) of supernatant remains on top of the sludge. The tank is not classified as a Watch List tank (Public Law 101-510); however, it was declared an assumed leaker in 1968, having lost nearly $90.8 \mathrm{~kL}$ (24 kgal) of waste. The tank was primary stabilized in 1979 and interim stabilized in 1984, and intrusion prevention was completed in 1988. There are no Unreviewed Safety Questions associated with tank 241-S-104. 
Table 1-2. Description of Tank 241-S-104.

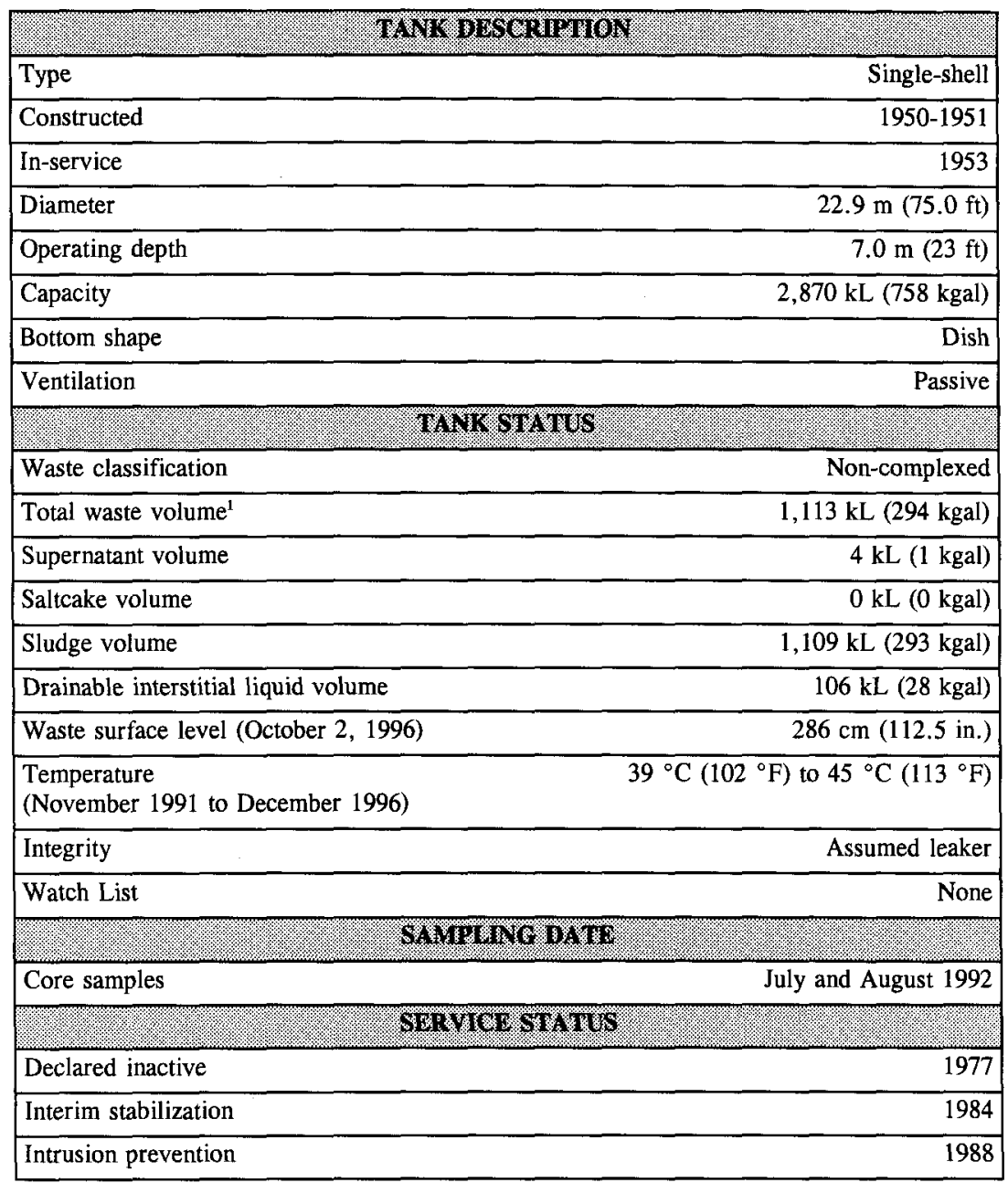

Note:

${ }^{1}$ Waste volume is estimated from surface-level measurements. 
HNF-SD-WM-ER-370 Rev. 1

This page intentionally left blank. 


\subsection{RESPONSE TO TECHNICAL ISSUES}

One technical issue has been identified for tank 241-S-104 (Brown et al. 1996):

- Does the waste pose or contribute to any recognized potential safety problems?

Data from three core samples taken in 1992 and flammability screening of the headspace in 1996 provided the means to partially address this issue. The response is detailed in the following sections. See Appendix B for sample and analysis data for tank 241-S-104.

\subsection{SAFETY SCREENING}

The data needed to screen the waste in tank 241-S-104 for potential safety problems are documented in Tank Safety Screening Data Quality Objective (Dukelow et al. 1995). These potential safety problems are: exothermic conditions in the waste; flammable gases in the waste and/or tank headspace; and criticality conditions in the waste. Each of these conditions is addressed separately below. Because tank 241-S-104 is not a Watch List tank, the safety screening DQO was the only safety-related DQO associated with the data analysis effort.

Even though core sampling of tank 241-S-104 preceded the implementation of the DQO process for addressing tank waste issues, the core sampling was consistent with the guidance of the DQO (two full-length cores from widely spaced risers). However, analysis of the core samples was conducted differently from the guidance of the current DQO. Nevertheless, the data collected can be used to address safety screening issues.

\subsubsection{Exothermic Conditions (Energetics)}

The first requirement outlined in the safety screening DQO (Dukelow et al. 1995) is to ensure that insufficient fuel exists in tank 241-S-104 to pose a safety hazard. The safety screening DQO required that the waste sample profile be tested for energetics every $24 \mathrm{~cm}$ ( 9.5 in.) to determine if the energetics exceed the safety threshold limit. The threshold limit for energetics is $480 \mathrm{~J} / \mathrm{g}$ on a dry weight basis.

Even though the subsampling scheme was not the same as currently prescribed, differential scanning calorimetry (DSC) was run on each segment and core composites. All the segment samples had no exotherms, but the composite sample from core 43 and core 44 had exotherms. The core 43 composite result was $4.5 \mathrm{~J} / \mathrm{g}$ (wet weight) and the rerun showed no evidence of exotherms. The core 44 composite highest result was $74.3 \mathrm{~J} / \mathrm{g}$ (wet weight basis). However, this result is questionable because all the segments from core 44 showed no evidence of exotherms. Furthermore, the thermogravimetric analysis (TGA) water result was 95 percent, indicating that the core 44 composite sample was not a good sample. 
Historically, there is no evidence that any exothermic agent should exist in this waste. Waste transfer records indicate that the major waste type expected to be in the tank is REDOX waste (Agnew et al. 1996a), and the REDOX waste type is expected to have few organic or ferrocyanide constituents. Analysis of a liquid sample taken in 1974 (Wheeler 1974) showed no evidence of exotherms (see Appendix B).

\subsubsection{Flammable Gas}

Vapor phase measurements, taken in the tank headspace on March 19, 1996, indicated that no flammable gas was detected ( 0 percent of the lower flammability limit).

\subsubsection{Criticality}

The safety threshold limit is $1 \mathrm{~g}{ }^{239} \mathrm{Pu}$ per liter of waste. Assuming that all alpha is from ${ }^{239} \mathrm{Pu}$ and assuming a density of $1.64 \mathrm{~g} / \mathrm{mL}, 1 \mathrm{~g} / \mathrm{L}$ of ${ }^{239} \mathrm{Pu}$ is equivalent to $37.5 \mu \mathrm{Ci} / \mathrm{g}$ of alpha activity. Waste samples were tested for total alpha activity for each composite sample. Concentrations in all composite samples ranged between 0.3 and $0.8 \mu \mathrm{Ci} / \mathrm{g}$, well below the limit. Additionally, as required by the DQO, the upper limit of the one-sided 95 percent confidence interval for these results was less than $1 \mathrm{~g} / \mathrm{L}$. The method used to calculate confidence limits is contained in Appendix C.

\subsection{OTHER TECHNICAL ISSUES}

Other factors in assessing tank safety are heat generation and temperature of the waste. Heat is generated in the tanks from radioactive decay. The heat load estimate based on the tank process history was $4,940 \mathrm{~W}(16,900 \mathrm{Btu} / \mathrm{hr}$ ) (Agnew et al. 1996b). The heat load estimate based on the tank headspace temperature was 3,093 W (10,563 Btu/hr) (Kummerer 1995). An estimate of the tank heat load based on the 1992 sample event was 3,910 W $(13,400 \mathrm{Btu} / \mathrm{hr})$. These estimates are well below the limit of $11,700 \mathrm{~W}(40,000 \mathrm{Btu} / \mathrm{hr})$ that separates high- and low-heat-load tanks (Smith 1986).

\subsection{SUMMARY}

The results from all analyses performed, when applied to resolve safety issues, show that no safety decision threshold limits are exceeded. Although the sampling and analysis were not conducted as prescribed in the current DQO (Dukelow et al. 1995), the data are sufficient to declare the tank safe. The analyses results are summarized in Table 2-1. 
Table 2-1. Summary of Safety Screening Results.

\begin{tabular}{|c|c|c|}
\hline Issire: & (3) Silsgue & Mesuli: \\
\hline \multirow[t]{4}{*}{$\begin{array}{l}\text { Safety } \\
\text { screening }\end{array}$} & Energetics & $\begin{array}{l}\text { No exotherms observed in any segment sample. Low } \\
\text { exotherms observed in composite samples. }\end{array}$ \\
\hline & Density & Only one segment measured $(1.64 \mathrm{~g} / \mathrm{mL})$. \\
\hline & Flammable gas & $\begin{array}{l}\text { Vapor measurement reported } 0 \text { percent of lower } \\
\text { flammability limit (combustible gas meter). }\end{array}$ \\
\hline & Criticality & $\begin{array}{l}\text { All analyses were between } 0.3 \text { and } 0.8 \mu \mathrm{Ci} / \mathrm{g} \text {, well } \\
\text { below } 37.5 \mu \mathrm{Ci} / \mathrm{g} \text { total alpha (within } 95 \text { percent } \\
\text { confidence limit on the mean for each sample). }\end{array}$ \\
\hline
\end{tabular}


HNF-SD-WM-ER-370 Rev. 1

This page intentionally left blank. 


\subsection{BEST-BASIS STANDARD INVENTORY ESTIMATE}

Information about the chemical and/or physical properties of tank wastes is used to perform safety analyses, engineering evaluations, and risk assessments associated with waste management activities, as well as to address regulatory issues. Waste management activities include overseeing tank farm operations and identifying, monitoring, and resolving safety issues associated with these operations and with the tank wastes. Disposal activities involve designing equipment, processes, and facilities for retrieving wastes and processing the wastes into a form suitable for long-term storage.

Chemical inventory information generally is derived using two approaches: 1) component inventories are estimated using the results of sample analyses; and 2) component inventories are predicted using a model based on process knowledge and historical information. The most recent model was developed by Los Alamos National Laboratory (Agnew et al. 1996b). Information derived from these two different approaches is often inconsistent.

An effort is underway to provide waste inventory estimates that will serve as standard characterization information for the various waste management activities (Hodgson and LeClair 1996). As part of this effort, an evaluation of available chemical information for tank 241-S-104 was performed that included:

- Data from three push-mode core samples collected in 1992. See Appendix B, Section B2.0 for data.

- Data from pre-1989 analyses, used for informational purposes only

- The inventory estimate for this tank (Agnew et al. 1996) generated from the Hanford defined waste (HDW) model. See Section A3.2 for the model estimate.

- Analytical data from TCRs for tanks with the same REDOX sludge waste types (241-S-104, this TCR), 241-S-107 (Simpson et al. 1996) and 241-S-101 (Kruger et al. 1996). A list of references used in this evaluation is provided at the end of Appendix D (Section D5.0).

Based on this evaluation and available sampling information, a best-basis inventory was developed for tank 241-S-104. For the following reasons, the sampling-based inventory was chosen as the best basis for those analytes for which sampling-based analytical values were available. 
- The engineering assessment supports the assumption that the sampling-based data appear reasonable, and the assessment could not substitute any additional information.

- For those few analytes where no values were available from the sampling-based inventory, the HDW model values were used with notation that they were of lower reliability.

- Investigation of the sample-based data revealed no cause for their rejection.

- The sample-based data were consistent with this tank's process history documentation.

The best-basis inventory for tank $241-\mathrm{S}-104$ is presented in Tables 3-1 and 3-2.

Table 3-1. Best-Basis Inventory Estimates for Nonradioactive Components in Tank 241-S-104 (December 4, 1996). (2 Sheets)

\begin{tabular}{|c|c|c|c|}
\hline : & 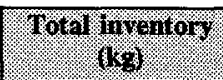 & 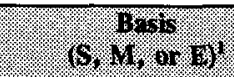 & 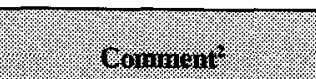 \\
\hline $\mathrm{Al}$ & 214,000 & $S$ & \\
\hline $\mathrm{Bi}$ & $<74.9$ & $\mathbf{S}$ & $\begin{array}{l}\text { Engineering assessment }= \\
90.4\end{array}$ \\
\hline $\mathrm{Ca}$ & 7,700 & $\mathbf{S}$ & \\
\hline$\overline{\mathrm{Cl}}$ & 5,840 & $S$ & \\
\hline $\mathrm{TIC}$ as $\mathrm{CO}_{3}$ & 7,560 & $S$ & \\
\hline$\overline{\mathrm{Cr}}$ & 4,290 & $\mathbf{S}$ & \\
\hline $\bar{F}$ & 292 & $\mathrm{E}$ & \\
\hline $\mathrm{Fe}$ & 3,140 & $\bar{S}$ & \\
\hline $\mathrm{Hg}$ & 74.5 & $\mathbf{M}$ & \\
\hline $\mathrm{K}$ & 548 & $\bar{S}$ & \\
\hline $\mathrm{La}$ & $2 \mathrm{E}-06$ & $\mathbf{M}$ & \\
\hline Mn & 1,890 & $S$ & \\
\hline $\mathrm{Na}$ & 220,000 & $\mathrm{~S}$ & \\
\hline $\mathrm{Ni}$ & 102 & $\bar{S}$ & \\
\hline $\mathrm{NO}_{2}$ & 38,000 & $S$ & \\
\hline $\mathrm{NO}_{3}$ & 349,000 & $\bar{S}$ & \\
\hline $\mathrm{OH}$ & $\mathrm{n} / \mathrm{r}$ & & \\
\hline $\mathrm{Pb}$ & 65.7 & $\mathrm{E}$ & The $M$ value $=2,240$ \\
\hline
\end{tabular}


Table 3-1. Best-Basis Inventory Estimates for Nonradioactive Components in Tank 241-S-104 (December 4, 1996). (2 Sheets)

\begin{tabular}{|c|c|c|c|}
\hline Inile & Tomal inveritomy & 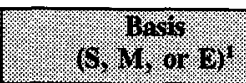 & Gomirion! \\
\hline $\mathrm{P}$ as $\mathrm{PO}_{4}$ & 518 & $S$ & \\
\hline $\mathrm{Si}$ & 2,430 & $\mathrm{~S}$ & \\
\hline $\mathrm{S}$ as $\mathrm{SO}_{4}$ & 4,140 & $S$ & \\
\hline$\overline{\mathrm{Sr}}$ & 774 & $S$ & \\
\hline TOC & 2,770 & $S$ & \\
\hline$\overline{U_{\text {TOTAL }}}$ & 12,200 & S & \\
\hline $\mathrm{Zr}$ & 61.2 & $S$ & \\
\hline
\end{tabular}

Notes:

$\begin{array}{lll}\mathrm{n} / \mathbf{r} & = & \text { not reported } \\ \mathrm{TIC} & = & \text { total inorganic carbon } \\ \mathrm{TOC} & = & \text { total organic carbon }\end{array}$

${ }^{1} \mathrm{~S}=$ Sample-based, $\mathbf{M}=$ HDW model-based, $\mathrm{E}=$ Engineering assessment-based.

${ }^{2}$ See Appendix D

Table 3-2. Best-Basis Inventory Estimates for Radioactive Components in Tank 241-S-104 (December 4, 1996).

\begin{tabular}{|c|c|c|c|}
\hline Arravire & $\begin{array}{l}\text { Totalingentary } \\
(\mathrm{Cl})\end{array}$ & 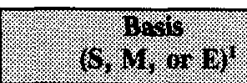 & Coininitint \\
\hline${ }^{3} \mathrm{H}$ & 6.15 & $S$ & \\
\hline${ }^{14} \mathrm{C}$ & 1.64 & $\mathrm{~S}$ & \\
\hline${ }^{90} \mathrm{Sr}$ & 566,000 & $\widehat{S}$ & \\
\hline${ }^{90} \mathrm{Y}$ & 566,000 & S & From ${ }^{90} \mathrm{Sr}$ \\
\hline${ }^{99} \mathrm{Tc}$ & 44.2 & $S$ & \\
\hline${ }^{137} \mathrm{Cs}$ & 114,000 & $S$ & \\
\hline${ }^{137 \mathrm{~m}} \mathrm{Ba}$ & 107,000 & $\mathrm{~S}$ & From ${ }^{137 m} \mathrm{Cs}$ \\
\hline${ }^{239} \mathrm{Pu}$ & 515 & $\bar{S}$ & ${ }^{*}$ includes ${ }^{240} \mathrm{Pu}$ \\
\hline
\end{tabular}

Notes:

$$
{ }^{1} \mathrm{~S}=\text { Sample-based, } \mathrm{M}=\text { HDW model-based, } \mathrm{E}=\text { Engineering assessment-based. }
$$


HNF-SD-WM-ER-370 Rev. 1

This page left blank intentionally. 


\subsection{RECOMMENDATIONS}

Core sampling of tank 241-S-104 occurred prior to implementation of the DQO process for TWRS characterization. Nevertheless, the data collected may be evaluated against the requirements of the current DQO. The current $\mathrm{DQO}$ applicable to the tank is the safety screening DQO (Dukelow et al. 1995). Analytical results for the safety screening DQO were well within the safety notification limits. The data collected from core sampling are sufficient to conclude that the tank is safe with respect to the issues in the safety screening DQO.

Table 4-1 summarizes the status of TWRS Project Hanford Management Contractor (PHMC) Program review and acceptance of the sampling and analysis results reported in this TCR. All DQO issues required to be addressed by sampling and analysis are listed the first column of Table 4-1. The second column indicates with a "Yes" or "No" whether the requirements of the DQO were met by the sampling and analysis activities performed. The third column indicates concurrence and acceptance by the program in TWRS responsible for the DQO that the sampling and analysis activities performed adequately meet the needs of the DQO. A "Yes" or "No" in column three indicates acceptance or disapproval of the sampling and analysis information presented in the TCR.

Table 4-1. Acceptance of Tank 241-S-104 Sampling and Analysis.

\begin{tabular}{|c|c|c|}
\hline V. & 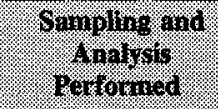 & 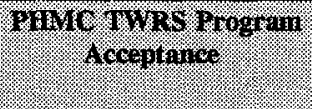 \\
\hline Safety screening DQO & Yes & Yes \\
\hline
\end{tabular}

Table 4-2 summarizes the status of TWRS Program review and acceptance of the evaluations and other characterization information contained in this report. The evaluation specifically outlined in this report is the evaluation to determine whether the tank is safe, conditionally safe, or unsafe. Column one lists the different evaluations performed in this report. Columns two and three are in the same format as Table 4-1. The manner in which concurrence and acceptance are summarized is also the same as that in Table 4-1. 
Table 4-2. Acceptance of Evaluation of Characterization Data and Information for Tank 241-S-104.

\begin{tabular}{|c|c|c|}
\hline 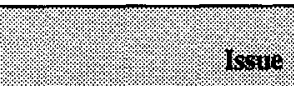 & Bringurar & 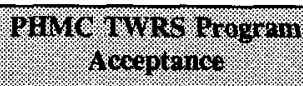 \\
\hline $\begin{array}{l}\text { Safety categorization } \\
\text { (tank is safe) }\end{array}$ & Yes & Yes \\
\hline
\end{tabular}

The waste currently in tank 241-S-104 may continue to be safely stored in the tank without special action. In addition, no additional characterization efforts are needed at this time. 


\subsection{REFERENCES}

Agnew, S. F., R. A. Corbin, T. B. Duran, K. A. Jurgensen, T. P. Ortiz, and B. L. Young, 1996a, Waste Status and Transaction Record Summary for the Northwest Quadrant of the Hanford 200 West Area, WHC-SD-WM-TI-614, Rev. 2, Westinghouse Hanford Company, Richland, Washington.

Agnew, S. F., J. Boyer, R. A. Corbin, T. B. Duran, J. R. Fitzpatrick, K. A. Jurgensen, T. P. Ortiz, and B. L. Young, 1996b, Hanford Tank Chemical and Radionuclide Inventories: HDW Model Rev. 3, LA-UR-96-858, Los Alamos National Laboratory, Los Alamos, New Mexico.

Brevick, C. H., L. A. Gaddis, and W. W. Pickett, 1996, Historical Tank Content Estimate for the Southwest Quadrant of the Hanford 200 West Areas, WHC-SD-WM-ER-352, Rev. OB, Westinghouse Hanford Company, Richland, Washington.

Brown, T. M., S. J. Eberlein, J. W. Hunt, and T. J. Kunthara, 1996, Tank Waste Characterization Basis, WHC-SD-WM-TA-164, Rev. 2, Westinghouse Hanford Company, Richland, Washington.

Dukelow, G. T., J. W. Hunt, H. Babad, and J. E. Meacham, 1995, Tank Safety Screening Data Quality Objective, WHC-SD-WM-SP-004, Rev. 2, Westinghouse Hanford Company, Richland, Washington.

Ecology, EPA, and DOE, 1996, Hanford Federal Facility Agreement and Consent Order, Washington State Department of Ecology, U.S. Environmental Protection Agency, and U.S. Department of Energy, Olympia, Washington.

Hill, J. G., W. I. Winters, B. C. Simpson, J. W. Buck, P. J. Chamberlain, and V. L. Hunter, 1991, Waste Characterization Plan for the Hanford Site Single-Shell Tanks, WHC-EP-0210, Rev. 3, Westinghouse Hanford Company, Richland, Washington.

Hodgson, K. M, and M. D. LeClair, 1996, Work Plan for Defining a Standard Inventory Estimate for Wastes Stored in Hanford Site Underground Tanks, WHC-SD-WM-WP-311, Rev. 1, Lockheed Martin Corporation, Richland, Washington.

Kocher, K. L., 1993, Single-Shell Waste Characterization Tank 241-S-104, Data Package, WHC-SD-WM-DP-031, Rev. 0, Westinghouse Hanford Company, Richland, Washington. 
Kruger, Albert A, B. J. Morris and L. J. Fergestrom, 1996, Tank Characterization Report for Single-Shell Tank 241-S-101, WHC-SD-WM-ER-613, Rev. 0, Westinghouse Hanford Company, Richland, Washington.

Kummerer, M., 1995, Topical Report on Heat Removal Characteristics of Waste Storage Tanks, WHC-SD-WM-SARR-010, Rev. 1, Westinghouse Hanford Company, Richland, Washington.

Public Law 101-510, 1990, "Safety Measures for Waste Tanks at Hanford Nuclear Reservation," Section 3137 of National Defense Authorization Act for Fiscal Year 1991.

Simpson, Brett C., J. G. Field, D. W. Engel and D. S. Daly, 1996, Tank Characterization Report for Single-Shell Tank 241-S-107, WHC-SD-WM-ER-589, Rev. 0, Westinghouse Hanford Company, Richland, Washington.

Smith, D. A., 1986, Single-Shell Tank Isolation Safety Analysis Report, WHC-SD-WM-SAR-006, Rev. 2, Westinghouse Hanford Company, Richland, Washington.

Wheeler, R. E., 1974, Analysis of Tank Farm Samples, Sample T-4184 104-S, (internal letter [number unknown] to R. L. Walser, August 12), Atlantic Richfield Company, Richland, Washington.

Winters, W. I., L. Jensen, L. M. Sasaki, R. L. Weiss, J. F. Keller, A. J. Schmidt, and M. G. Woodruff, 1990, Waste Characterization Plan for the Hanford Site Single-Shell Tanks, WHC-EP-0210, Rev.1, Westinghouse Hanford Company, Richland, 
HNF-SD-WM-ER-370 Rev. 1

\section{APPENDIX A}

HISTORICAL TANK INFORMATION

A-1 
HNF-SD-WM-ER-370 Rev. 1

This page intentionally left blank. 


\section{APPENDIX A}

\section{HISTORICAL TANK INFORMATION}

Appendix A describes tank 241-S-104 based on historical information. For this report, historical information includes any information about the tank's fill history, waste types, surveillance, or modeling data. This information is necessary for providing a balanced assessment of the sampling and analytical results.

This appendix contains the following information:

- Section A1: Current status of the tank, including the current waste levels and the stabilization and isolation status of the tank.

- Section A2: Information about the design of the tank.

- Section A3: Process knowledge of the tank; i.e., the waste transfer history and the estimated contents of the tank based on modeling data.

- Section A4: Surveillance data for tank 241-S-104, including surface-level readings, temperatures, and a description of the waste surface based on photographs.

- Section A5: References for Appendix A.

Historical sampling results (samples obtained prior to 1989) are included in Appendix B.

\section{A1.0 CURRENT TANK STATUS}

As of September 30, 1996, tank 241-S-104 contained 1,113 kL (294 kgal) of waste. The waste volumes were estimated using a manual tape surface level gauge (Hanlon 1996). The tank contents summary is contained in Table A1-1.

Tank 241-S-104 is passively vented to the atmosphere through a breather filter (Bergmann 1991) and is not on the Watch List (Public Law 101-510). All monitoring systems are currently in compliance with documented standards (Hanlon 1996). Current temperature data indicate that the maximum temperature in the tank is $45^{\circ} \mathrm{C}\left(113{ }^{\circ} \mathrm{F}\right)$. Tank 241-S-104 is listed as a low-heat-load tank (Hanlon 1996). 
Table A1-1. Tank Contents Status Summary. ${ }^{1}$

\begin{tabular}{|c|c|}
\hline W: Waste Troo & 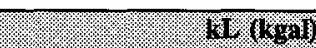 \\
\hline Total waste & $1,113(294)$ \\
\hline Supernatant & $4(1)$ \\
\hline Sludge $^{1}$ & $1,109(293)$ \\
\hline Saltcake ${ }^{1}$ & $0(0)$ \\
\hline Drainable interstitial liquid & $106(28)$ \\
\hline Drainable liquid remaining & $110(29)$ \\
\hline Pumpable liquid remaining & $87(23)$ \\
\hline
\end{tabular}

Notes:

${ }^{1}$ Hanlon (1996)

The current designation of the tank contents is non-complexed waste. This is a general term to describe waste that does not have a high content of carbon complexants or organic carbon. The tank is an assumed leaker, has been interim stabilized, and has undergone intrusion prevention (Hanlon 1996).

\section{A2.0 TANK DESIGN AND BACKGROUND}

Tank 241-S-104 is a carbon steel tank within a reinforced concrete shell and dome. As described in the Historical Tank Content Estimate for the Southwest Quadrant of the Hanford 200 West Area (Brevick et al. 1995), the tank has a diameter of $22.9 \mathrm{~m} \mathrm{(75} \mathrm{ft),} \mathrm{an} \mathrm{operating}$ depth of $7.0 \mathrm{~m}(23 \mathrm{ft})$, and a capacity of $2,870 \mathrm{~kL}(758 \mathrm{kgal})$. The basic design of tank 241-S-104 is shown in Figure A2-1. Instruments access tank 241-S-104 through risers and monitor the pressure, temperature, sludge level, and other bulk tank characteristics (Bell 1994). The positions of these risers are shown in Figure A2-2. The tank 241-S-104 risers and their sizes and general use are listed in Table A2-1.

The 241-S Tank Farm was built in 1950 and 1951. It is located at the southern end of the 200 West Area. Figure A2-3 details the Hanford Site's 200 West Area and the location of the 241-S Tank Farm. Tank 241-S-104 is located on the eastern side of the second row of the 241-S Tank Farm.

Tank 241-S-104 is the first, or primary, tank in a "cascade" connecting it to tanks 241-S-105 and 241-S-106. A cascade is a system in which a number of tanks are connected in 
HNF-SD-WM-ER-370 Rev. 1

Figure A2-1. Tank 241-S-104 Cross Section and Schematic.

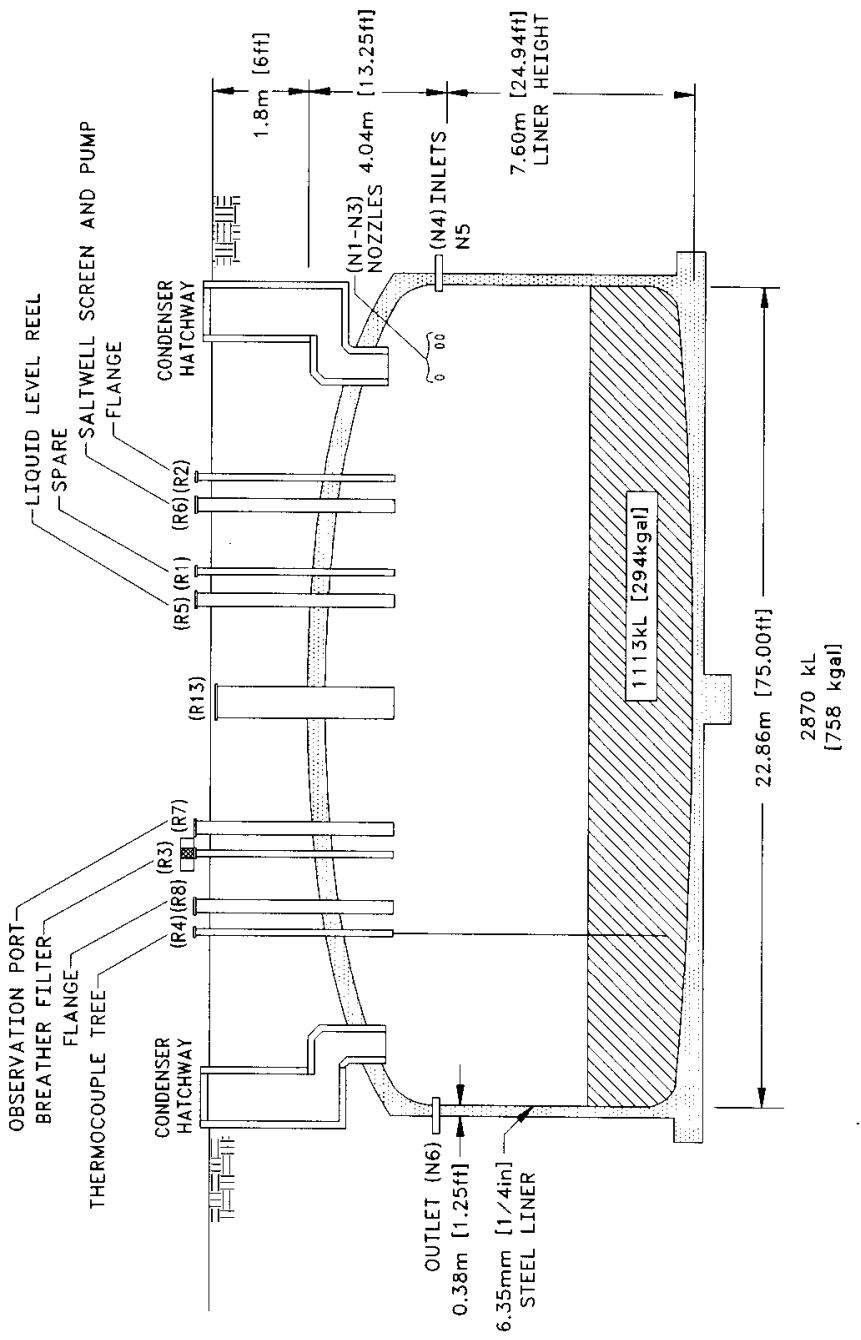


HNF-SD-WM-ER-370 Rev. 1

Figure A2-2. Riser Configuration for Tank 241-S-104.

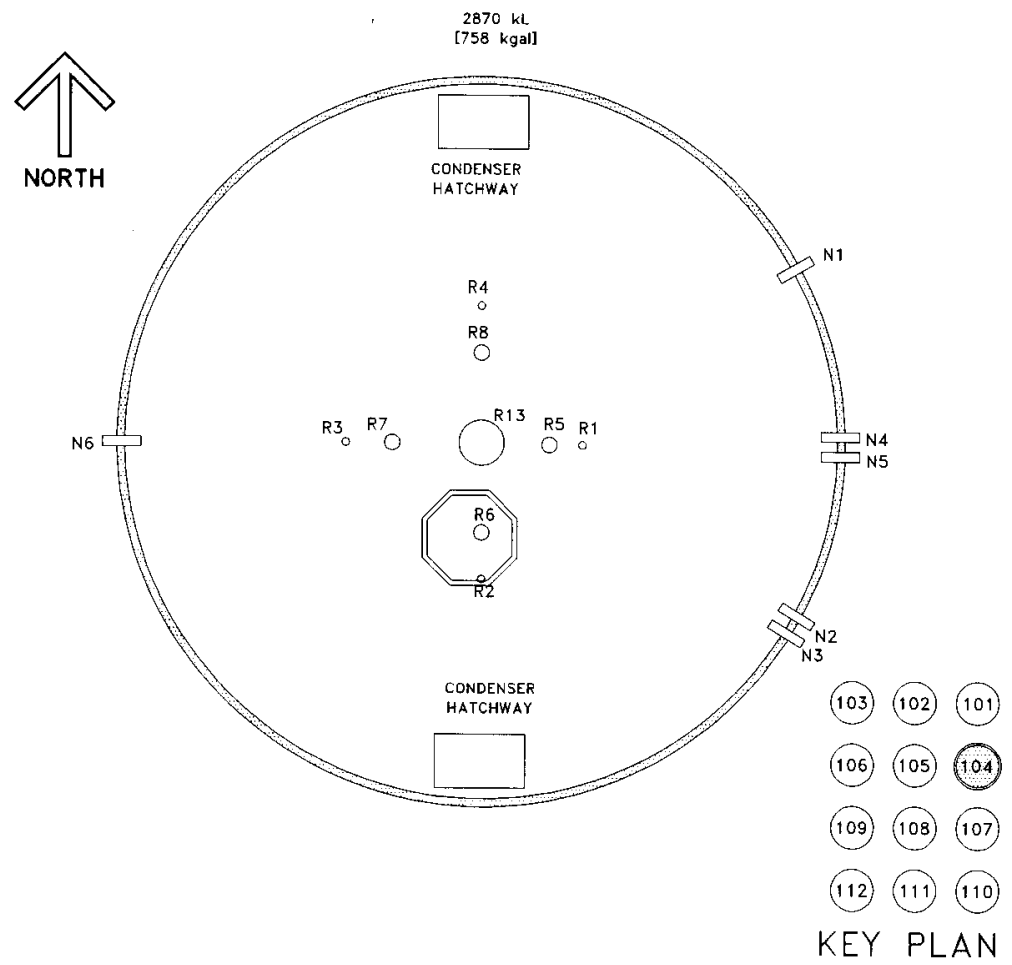


Table A2-1. Tank 241-S-104 Risers. ${ }^{1}$ (2 sheets)

\begin{tabular}{|c|c|c|}
\hline Nimber: & Dianeter: & Meceription ond Comment? \\
\hline $\mathrm{R}^{*}$ * & 4 & Spare (Blank CEO-41057 2/27/87) \\
\hline $\mathrm{R} 2$ & 4 & $\begin{array}{l}\text { Flange (Benchmarked CEO-36908 12/11/86) (Steel LOW } \\
\text { ECN-614180 9/27/94) }\end{array}$ \\
\hline R3* & 4 & $\begin{array}{l}\text { Breather filter (Breather filter CEO-41057 2/27/87) (Breather } \\
\text { filter/vapor sampling assembly ECN-601024 } \\
8 / 10 / 93 \text { ) }\end{array}$ \\
\hline R4 & 4 & Thermocouple tree \\
\hline R5 & 12 & $\begin{array}{l}\text { Liquid level reel (Benchmark CEO-36908 } 12 / 11 / 86 \text { and } \\
\text { ECN-614184 10/31/94) }\end{array}$ \\
\hline R6 & 12 & Saltwell screen and pump \\
\hline $\mathrm{R} 7^{*}$ & 12 & $\begin{array}{l}\text { B-222 observation port (Benchmark CEO-36908 12/11/86) } \\
\text { (Benchmark ECN-614184 10/31/94) }\end{array}$ \\
\hline R8* & 12 & Blind flange \\
\hline R13 & 42 & Pump, weather covered in pit \\
\hline N1 & 3 & Spare nozzle, capped \\
\hline $\mathrm{N} 2$ & 3 & Spare nozzle, capped \\
\hline N3 & 3 & Spare nozzle, capped \\
\hline N4 & 3 & Inlet line V539, sealed in Diversion Box 241-S-151 \\
\hline N5 & 3 & Inlet line V538, sealed in Diversion Box 241-S-151 \\
\hline N6 & 3 & Overflow \\
\hline
\end{tabular}

Notes:

*Denotes risers tentatively available for sampling (Lipnicki 1996).

$\mathrm{CEO}=$ change engineering order

$\mathrm{ECN}=$ engineering change notice

LOW $=$ liquid observation well

${ }^{1}$ Alstad (1993), Lipnicki (1996)

${ }^{2}$ Dates shown in mm/dd/yy format 
series by pipes. The pipes are located at the top of the tanks' working depths. When the cascade system was in use, waste added to the primary tank would flow to the next tank without overfilling the primary tank. By using a cascade, fewer connections needed to be made during waste handling operations. The cascade method reduced waste handling requirements, personnel exposure, and the chance of a loss of tank integrity from waste overflow. Another advantage of using the cascade system was waste volume reduction from the disposal of clarified liquid waste. Entrained solids and precipitates would most likely settle in the primary tank (in this case, tank 241-S-104), and the clarified liquids would flow through the cascade to the secondary tanks (241-S-105 and 241-S-106). Historically, this practice led to the rapid accumulation of solids in the primary tank, and allowed the disposal of clarified liquid from the secondary tanks into cribs.

Tank 241-S-104 went into service in 1953 when it received REDOX process waste (Anderson 1990). This waste was produced during the recovery of plutonium from nuclear fuel. The REDOX waste cascaded to tank 241-S-105 and on to tank 241-S-106. This cascade line was not used after 1956. Waste from tank 241-S-104 has been discharged to various tanks and to cribs. Tank $241-\mathrm{S}-104$ received its last waste additions in 1965 . After losing $90.8 \mathrm{~kL}$ ( $24 \mathrm{kgal}$ ) of waste, the tank was declared an assumed leaker and was taken out of service in 1968 (Brevick et al. 1995). Four dry wells were drilled and most of the supernatant was removed in 1970. A pump was installed in 1974, and salt well pumping was completed in 1976. In 1978, a jet pump was installed (Welty 1988). The tank was primary stabilized in 1979 (Welty 1988), and interim stabilized in December 1984 (Swaney 1994). Primary stabilization involved removal of most of the supernatant and much of the interstitial liquid in the tank. Removing liquids minimizes the risk of waste leaking out of the tank. Interim stabilization, in this case, was an administrative designation with requirements similar to primary stabilization. Intrusion prevention was completed on tank $241-\mathrm{S}-104$ in 1988. Intrusion prevention involves the completion of the physical effort required to minimize the potential for liquids to be inadvertently added to an inactive storage tank.

\section{A3.0 PROCESS KNOWLEDGE}

The sections below: 1) provide information about the transfer history of tank 241-S-104; 2) describe the process wastes that made up the transfers; and 3) give an estimate of the current tank contents based on transfer history.

\section{A3.1 WASTE TRANSFER HISTORY}

Table A3-1 summarizes the waste transfer history of tank 241-S-104 (Agnew et al. 1996a). Tank 241-S-104 began its service life in 1953 when it received REDOX process waste. This waste was produced during the recovery of plutonium and uranium from nuclear fuel. The tank also received small amounts of REDOX-process-associated wastes: salt waste, 
laboratory waste, hot condensate containing moderate levels of radionuclides, coating waste, and centrifuge cake waste in multiple transfers (Anderson 1990). All these wastes were produced at the REDOX Plant. Tank 241-S-104 reached its maximum operating level during the second quarter of 1953 , and further additions caused the waste to cascade to tank 241-S-105.

The wastes in tank 241-S-104 began to self-boil in 1953. In that same year, surface condensers were installed. The surface condensers allowed concentration of wastes by disposing of vapor condensate to cribs. These condensers operated between 1953 and 1956.

Waste from the REDOX Plant continued to be added to tank 241-S-104 until 1955. At that time, use of this cascade system was stopped. Flush water was also added to the tank in 1955. The tank received supernatant waste from tank 241-S-107 in the second quarter of 1965. The tank was assumed to be leaking in 1968. Approximately half of the tank volume was transferred to tank 241-TY-103 in 1970. Additional supernatant was transferred out of the tank to tank 241-S-107 in 1974 and 1975. A graphical waste volume history of tank 241-S-104 is included as Figure A4-1.

Table A3-1. Tank 241-S-104 Major Transfers. ${ }^{1}$

\begin{tabular}{|c|c|c|c|c|c|}
\hline \multirow[b]{2}{*}{ Thourcer. } & \multirow[b]{2}{*}{ Bestimstiving } & \multirow[b]{2}{*}{ Waste The } & \multirow[b]{2}{*}{ Thine Penioa } & \multicolumn{2}{|c|}{ Jatrinated waste volma } \\
\hline & & & & 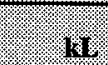 & l.gal: \\
\hline REDOX & $241-S-104$ & R, CWR & 1953 & 8,502 & 2,244 \\
\hline S-104 & 241-S-105 & $\mathrm{R}, \mathrm{CWR}$ & 1953 & 5,610 & 1,482 \\
\hline S-104 & S-003 Crib & Condensate & $1953-1956$ & 2,188 & 578 \\
\hline REDOX & $241-S-104$ & $\overline{R, C W R}$ & $1954-1955$ & 1,768 & $\begin{array}{l}467 \\
\end{array}$ \\
\hline $\begin{array}{l}\text { Miscellaneous } \\
\text { sources }\end{array}$ & $241-S-104$ & Water & 1955 & 136 & 36 \\
\hline S-107 & $241-S-104$ & Supernatant & 1965 & 363 & 96 \\
\hline S-104 & Evaporator & $\overline{R, C W R}$ & 1969 & & 652 \\
\hline Evaporator & $241-S-104$ & $\overline{\text { RSItCk }}$ & 1969 & & 652 \\
\hline S-104 & 241-TY-013 & Supernatant & 1970 & & 474 \\
\hline & $241-S-107$ & Supernatant & 1974 & 30 & 8 \\
\hline
\end{tabular}

Notes:
$\mathrm{R}=$ REDOX (used to denote various REDOX wastes)
RSltCk $=$ REDOX saltcake
CWR = Coating waste from decladding of aluminum clad fuel in the REDOX Plant (REDOX cladding waste)

${ }^{1}$ Agnew (1996) 


\section{A3.2 HISTORICAL ESTIMATION OF TANK CONTENTS}

The historical transfer data used for this estimate are from the following sources:

- Waste Status and Transaction Record Summary for the Southwest Quadrant of the Hanford 200 East Area (WSTRS) (Agnew et al. 1996). The WSTRS is a tank-by-tank quarterly summary spreadsheet of waste transactions.

- Hanford Tank Chemical and Radionuclide Inventories: HDW Model Rev 4 (Agnew et al. 1997). This document contains the HDW list, the supernatant mixing model (SMM), and the tank layer model (TLM).

- Historical Tank Content Estimate for the Southwest Quadrant of the Hanford 200 West Areas (Brevick et al. 1995). This document compiles and summarizes much of the process history, design, and technical information regarding the underground waste storage tanks in the southwest quadrant of the Hanford Site 200 West Area.

- Tank layer model (TLM). The TLM defines the sludge and saltcake layers in each tank using waste composition and waste transfer information.

- Supernatant mixing model (SMM). The SMM is a subroutine within the HDW model that calculates the volume and composition of certain supernatant blends and concentrates.

Using these records, the TLM defines the sludge and saltcake layers in each tank. The SMM uses information from both the WSTRS and the TLM to describe the supernatants and concentrates in each tank. Together the WSTRS, TLM, and SMM determine each tank's inventory estimate. These model predictions are considered estimates that require further evaluation using analytical data.

The major waste types received by tank 241-S-104 were REDOX process waste (R) and REDOX cladding waste (CWR).

Based on the TLM, Figure A3-1 shows a graphical representation of the estimated waste type and volume for the tank layer. The waste types present for this tank are R waste, CWR waste, and R saltcake (RSltCk). RSltCk waste is assumed to be from waste self-concentrating within the tank. R1 waste is REDOX waste generated between 1952 and 1957, and CWR1 waste is REDOX waste with aluminum-clad fuel, generated between 1952 and 1960. 
HNF-SD-WM-ER-370 Rev. 1

Figure A3-1. Tank Layer Model.

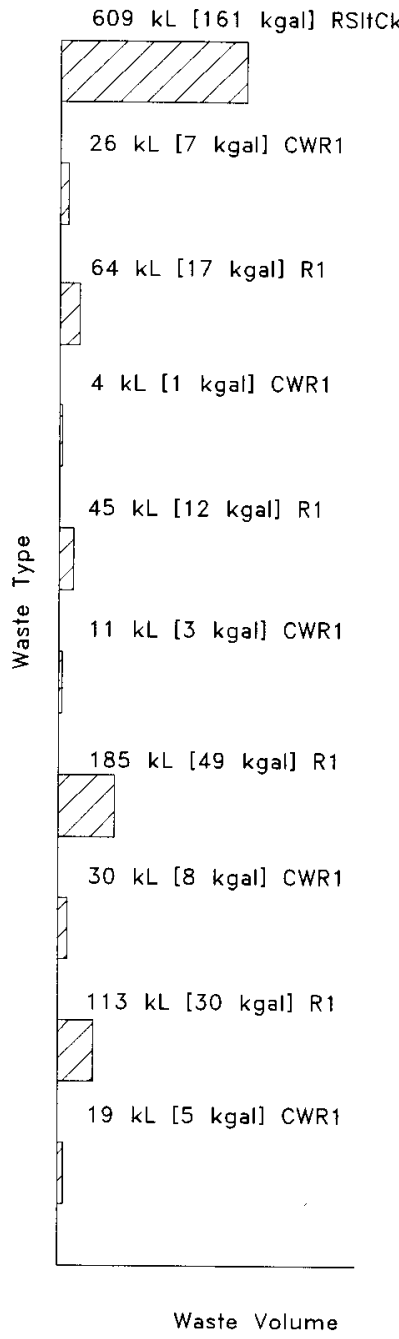


Table A3-2 shows the historical estimate of the expected waste constituents and their concentrations.

Table A3-2. Historical Tank Inventory Estimate. ${ }^{1,2,3}$ (2 sheets)

\begin{tabular}{|c|c|c|c|}
\hline \multirow{2}{*}{\multicolumn{4}{|c|}{ (1) }} \\
\hline & & & \\
\hline \multicolumn{4}{|c|}{ 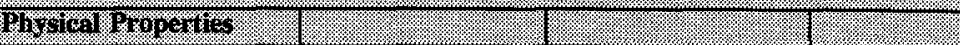 } \\
\hline Total waste & $1.93 \mathrm{E}+06 \mathrm{~kg}$ & (294 kgal) & \\
\hline Heat load & $4.67 \mathrm{~kW}$ & $(1.60 \mathrm{E}+\overline{04} \mathrm{Btu} / \mathrm{hr})$ & \\
\hline Bulk density ${ }^{4}$ & $1.73\left(\mathrm{~g} / \mathrm{cm}^{3}\right)$ & & \\
\hline Water wt \% & 31.1 & & \\
\hline TOC wt\% C (wet) ${ }^{4}$ & $2.86 \mathrm{E}-03$ & & \\
\hline 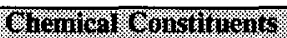 & gr. & 3010 & (1) \\
\hline $\mathrm{Na}+$ & 11.0 & $1.46 \mathrm{E}+05$ & $2.82 \mathrm{E}+05$ \\
\hline$\overline{\mathrm{Al}^{3+}}$ & 5.34 & $8.32 E+04$ & $1 . \overline{60} \mathrm{E}+\overline{05}$ \\
\hline $\mathrm{Fe}^{3+}($ total Fe) & 0.395 & $1.27 \mathrm{E}+04$ & $2.46 \mathrm{E}+04$ \\
\hline $\mathrm{Cr}^{3+}$ & 0.473 & $1.42 \mathrm{E}+04$ & $2 . \overline{74 E+04}$ \\
\hline $\mathrm{Bi}^{3+}$ & $3 . \overline{78 E-06}$ & 0.456 & 0.879 \\
\hline $\mathrm{La}^{3+}$ & $9.31 \mathrm{E}-12$ & $7.47 \mathrm{E}-07$ & $1.44 \mathrm{E}-06$ \\
\hline $\mathrm{Hg}^{2+}$ & $3.34 \mathrm{E}-04$ & 38.6 & 74.5 \\
\hline$\overline{\mathrm{Zr}\left(\text { as } \mathrm{ZrO}(\mathrm{OH})_{2}\right)}$ & $3.77 \mathrm{E}-07$ & $1.99 \mathrm{E}-02$ & $3.83 \mathrm{E}-02$ \\
\hline $\mathrm{Pb}^{2+}$ & $9.70 \mathrm{E}-03$ & $1.16 \mathrm{E}+03$ & $2.24 \mathrm{E}+03$ \\
\hline $\mathrm{Ni}^{2+}$ & $2.70 \mathrm{E}-02$ & 914 & $1.76 \mathrm{E}+03$ \\
\hline $\mathrm{Sr}^{2+}$ & 0 & 0 & 0 \\
\hline $\mathrm{Mn}^{4+}$ & $2.75 \mathrm{E}-05$ & 0.873 & 1.68 \\
\hline $\mathrm{Ca}^{2+}$ & 0.133 & $3.07 \mathrm{E}+03$ & $5.42 \mathrm{E}+03$ \\
\hline $\mathrm{K}^{+}$ & $2.19 \mathrm{E}-02$ & 494 & 951 \\
\hline$\overline{\mathrm{OH}^{-}}$ & $23.1^{4}$ & $2.26 \mathrm{E}+05$ & $4.36 \mathrm{E}+05$ \\
\hline $\mathrm{NO}_{3}^{-}$ & 4.87 & $1.74 \mathrm{E}+05$ & $3.36 \mathrm{E}+05$ \\
\hline $\mathrm{NO}_{2}^{-}$ & 1.64 & $4.36 \mathrm{E}+04$ & $8.41 \mathrm{E}+04$ \\
\hline $\mathrm{CO}_{3}^{2-}$ & 0.135 & $4.69 \mathrm{E}+03$ & $9.04 \mathrm{E}+03$ \\
\hline $\mathrm{PO}_{4}^{3-}$ & $2.45 \mathrm{E}-04$ & $13 . \overline{4}$ & 25.9 \\
\hline $\mathrm{SO}_{4}^{2-}$ & $2.68 \mathrm{E}-02$ & $1.48 \mathrm{E}+03$ & $2.86 \mathrm{E}+03$ \\
\hline $\mathrm{Si}$ (as $\left.\mathrm{SiO}_{3}^{2-}\right)$ & $7.59 \mathrm{E}-02$ & $1.23 \mathrm{E}+03$ & $2.37 \mathrm{E}+03$ \\
\hline $\mathrm{F}^{-}$ & $1.95 \mathrm{E}-04$ & 2.14 & 4.12 \\
\hline
\end{tabular}


HNF-SD-WM-ER-370 Rev. 1

Table A3-2. Historical Tank Inventory Estimate. ${ }^{1,2,3}$ (2 sheets)

\begin{tabular}{|c|c|c|c|}
\hline \multicolumn{4}{|c|}{ 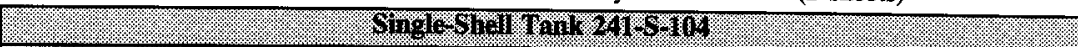 } \\
\hline \multicolumn{4}{|c|}{ 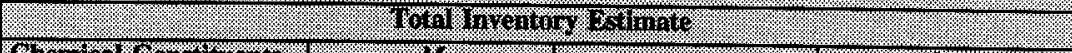 } \\
\hline 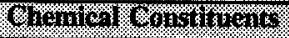 & 4 & 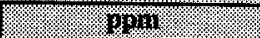 & 12 \\
\hline $\mathrm{Cl}^{-}$ & $9.30 \mathrm{E}-02$ & $1.90 \mathrm{E}+03$ & $3.67 \mathrm{E}+03$ \\
\hline $\mathrm{C}_{6} \mathrm{H}_{5} \mathrm{O}_{7}^{3-}$ & $2.02 \mathrm{E}-04$ & 22.0 & 42.4 \\
\hline EDTA $^{4-}$ & $7.85 \mathrm{E}-06$ & 1.31 & 2.52 \\
\hline HEDTA $^{3-}$ & $6.52 \mathrm{E}-06$ & 1.03 & 1.99 \\
\hline glycolate $^{-}$ & $2.84 \mathrm{E}-04$ & 12.3 & 3.7 \\
\hline acetate & $2.95 \mathrm{E}-05$ & 1.01 & 1.94 \\
\hline oxalate $^{2-}$ & $1.22 \mathrm{E}-11$ & $6.20 \mathrm{E}-07$ & $1.19 \mathrm{E}-06$ \\
\hline$\overline{\mathrm{DBP}}$ & $1.79 \mathrm{E}-04$ & 21.7 & 41.8 \\
\hline butanol & $1.79 \mathrm{E}-04$ & 7.65 & 14.7 \\
\hline $\mathrm{NH}_{3}$ & 0.114 & $1.12 \mathrm{E}+03$ & $2.15 \mathrm{E}+\overline{03}$ \\
\hline $\mathrm{Fe}(\mathrm{CN})_{6}^{4}$ & 0 & 0 & 0 \\
\hline \multicolumn{4}{|l|}{ Rarifilogical Constifuents } \\
\hline $\mathrm{Pu}$ & $5.79 \mathrm{E}-03 \mathrm{~g} / \mathrm{L}$ & & $6.44(\mathrm{~kg})$ \\
\hline $\mathrm{U}$ & $2.29 \mathrm{E}-02(M)$ & $3.15 \mathrm{E}+03(\mu \mathrm{g} / \mathrm{g})$ & $6.07 \mathrm{E}+03(\mathrm{~kg})$ \\
\hline $\mathrm{Cs}$ & $0.199(\mathrm{Ci} / \mathrm{L})$ & $115(\mu \mathrm{Ci} / \mathrm{g})$ & $2.21 \mathrm{E}+05(\mathrm{Ci})$ \\
\hline Sr & $0.485(\mathrm{Ci} / \mathrm{L})$ & $280(\mu \mathrm{Ci} / \mathrm{g})$ & $5.40 \mathrm{E}+05(\mathrm{Ci})$ \\
\hline
\end{tabular}

Notes:

$\begin{array}{lll}\text { DBP } & =\text { dibutyl phosphate } \\ \text { wt } \%= & \text { weight percent }\end{array}$

${ }^{1}$ Unknowns in the tank solids inventory are assigned by the TLM.

${ }^{2}$ Volume average for density, mass average water wt $\%$ and TOC weight percent carbon (wt $\% \mathrm{C}$ ).

${ }^{3}$ Historical tank inventory predictions have not been validated and should be used with caution.

${ }^{4}$ Total $\mathrm{OH}$, not free $\mathrm{OH}$ 


\section{A4.0 SURVEILLANCE DATA}

Tank 241-S-104 surveillance consists of surface-level measurements (liquid and solid), temperature monitoring inside the tank (waste and headspace), and leak detection well (drywell) monitoring for radioactivity outside the tank. Surveillance data provide the basis for determining tank integrity.

Liquid-level measurements can indicate if the tank has a major leak. Solid surface-level measurements provide an indication of physical changes in and consistencies of the solid layers of a tank. Drywells located around the tank perimeter may show increased radioactivity as a result of leaks.

\section{A4.1 SURFACE-LEVEL READINGS}

Tank 241-S-104 is categorized as an assumed leaker. To determine the surface level of the waste, tank $241-\mathrm{S}-104$ is equipped with a manual tape gauge. The manual tape uses a conductivity probe lowered by a hand crank until contact is made with the waste surface and an electric circuit is completed. The measurement is later manually recorded on the Surveillance Analysis Computer System.

Surface-level readings are currently being taken quarterly. A recent manual tape reading was $2.86 \mathrm{~m}$ (112.5 in.), taken October 2, 1996. As is expected with an interim stabilized, out-of-service tank, the waste level in tank $241-\mathrm{S}-104$ has remained very consistent for several years. A level history graph of the volume measurements is presented in Figure A4-1.

\section{A4.2 INTERNAL TANK TEMPERATURES}

To measure local tank temperatures, a probe with 14 thermocouples assembled in a pipe (called a thermocouple tree) is inserted into tank 241-S-104 through riser 4 . The thermocouple on the tree monitors the waste temperatures at various levels in the tank. Data are only available after January 1995 for thermocouples 1 through 6 and 11 .

Temperature readings for tank 241-S-104 since 1991 are plotted in Figure A4-2. Each plotted temperature is the highest of the readings recorded by the thermocouples on the thermocouple tree. The highest temperatures observed in the tank are at 1.5 to $2.3 \mathrm{~m}$ (60 to 90 in.) from the bottom. No temperature readings are available before 1991 , most likely because no temperature readings were taken or because temperature data sheets were misplaced and thus not available when the database was later compiled. Temperatures are taken biannually, and the last available maximum temperature reading for tank 241-S-104 was $41.1{ }^{\circ} \mathrm{C}\left(106^{\circ} \mathrm{F}\right)$, taken on January 13, 1997. Figure A4-2 illustrates that temperatures have been stable since 1991 , ranging between $39^{\circ} \mathrm{C}$ and $45.5^{\circ} \mathrm{C}\left(102^{\circ} \mathrm{F}\right.$ and $\left.114{ }^{\circ} \mathrm{F}\right)$. 


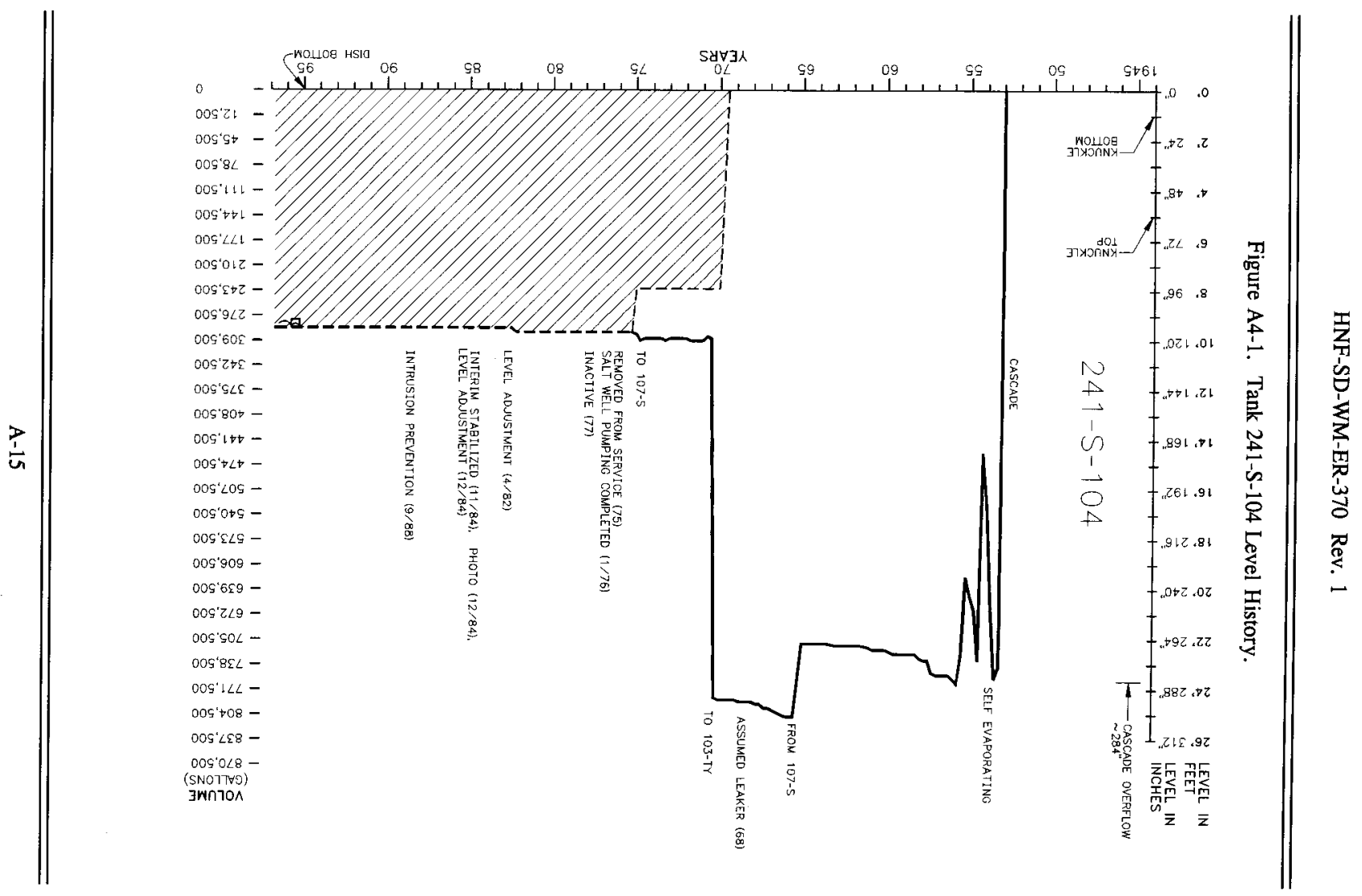


HNF-SD-WM-ER-370 Rev. 1

Figure A4-2. Tank 241-S-104 High Temperature Plot.

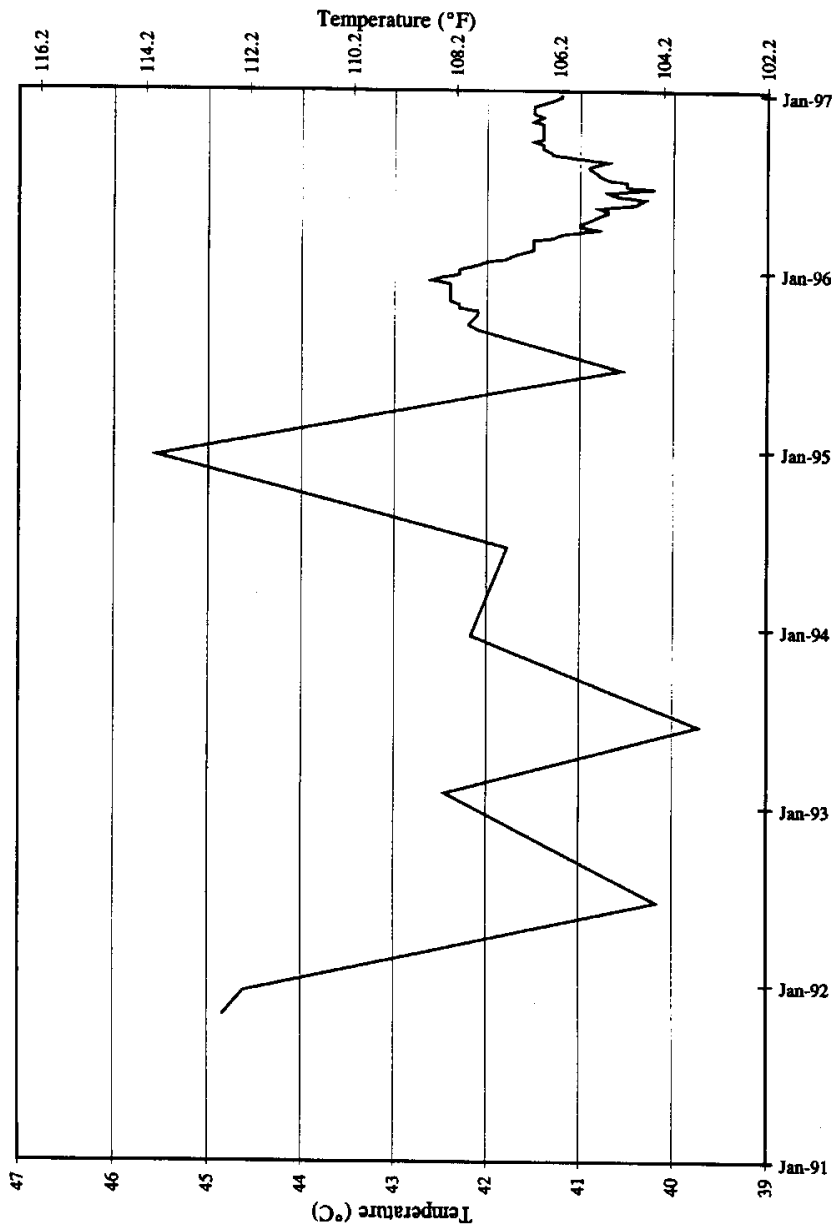




\section{A4.3 TANK 241-S-104 PHOTOGRAPHS}

The tank 241-S-104 photograph shows solid material over the entire tank surface except for a few small, randomly dispersed pools of yellow liquid. From samples taken in 1976 and 1992, the waste was described as gray, with the consistency of mud, dough, or putty. In the photograph, the waste appears brown. A salt well screen penetrates what appears to be the deepest pool of liquid remaining in the tank. A manual tape level measuring device and a temperature probe are also apparent. Because the photograph was taken after the tank was stabilized in 1984, it should represent the current tank conditions. The tank waste level has remained stable at almost $290 \mathrm{~cm}$ (114 in.), which equates to approximately $1,113 \mathrm{~kL}$ (294 kgal). 
HNF-SD-WM-ER-370 Rev. 1

This page left blank intentionally. 


\section{A5.0 APPENDIX A REFERENCES}

Agnew, S. F., R. A. Corbin, T. B. Duran, K. A. Jurgensen, T. P. Ortiz, B. L. Young, 1996, Waste Status and Transaction Record Summary for the Southwest Quadrant of the Hanford 200 West Area, WHC-SD-WM-TI-614, Rev. 1, Westinghouse Hanford Company, Richland, Washington.

Agnew, S. F., J. Boyer, R. A. Corbin, T. B. Duran, J. R. Fitzpatrick, K. A. Jurgensen, T. P. Ortiz, and B. L. Young, 1997, Hanford Tank Chemical and Radionuclide Inventories: HDW Model Rev. 4, LA-UR-96-3860, Los Alamos National Laboratory, Los Alamos, New Mexico.

Alstad, A. T., 1993, Riser Configuration Document for Single-Shell Waste Tanks, WHC-SD-RE-TI-053, Rev. 9, Westinghouse Hanford Company, Richland, Washington.

Anderson, 1990, A History of The 200 Area Tank Farms, WHC-MR-0132, Rev. 0, Westinghouse Hanford Company, Richland, Washington.

Bell, K. E., 1994, Tank Waste Remediation System Tank Waste Analysis Plan, WHC-SD-WM-PLN-077, Rev. 0, Westinghouse Hanford Company, Richland, Washington.

Bergmann, L. M., 1991, Single-Shell Tank Isolation Safety Analysis Report, WHC-SD-WM-SAR-006, Rev. 2, Westinghouse Hanford Company, Richland, Washington.

Brevick, C. H., L. A. Gaddis, and W. W. Pickett, 1995, Historical Tank Content Estimate for the Southwest Quadrant of the Hanford 200 West Areas, WHC-SD-WM-ER-352, Rev. 0A, Westinghouse Hanford Company, Richland, Washington.

Hanion, B. L., 1996, Tank Farm Surveillance and Waste Status Summary Report for Month Ending September 30, 1996, WHC-EP-0182-102, Westinghouse Hanford Company, Richland, Washington.

Lipnicki, J., 1996, Waste Tank Risers Available for Sampling, WHC-SD-WM-TI-710, Rev. 3, Westinghouse Hanford Company, Richland, Washington.

Public Law 101-510, 1990, "Safety Measures for Waste Tanks at Hanford Nuclear Reservation," Section 3137 of National Defense Authorization Act for Fiscal Year 1991.

Swaney, S. L., 1994, Single-Shell Tank Stabilization Record, WHC-SD-RE-TI-178, Rev. 4, Westinghouse Hanford Company, Richland, Washington. 
Welty, R. K., 1988, Waste Storage Tank Status and Leak Detection Criteria, WHC-SD-WM-TI-356, Rev. 2, Westinghouse Hanford Company, Richland, Washington. 
HNF-SD-WM-ER-370 Rev. 1

APPENDIX B

SAMPLING OF TANK 241-S-104

B-1 
HNF-SD-WM-ER-370 Rev. 1

This page intentionally left blank. 


\section{APPENDIX B}

\section{SAMPLING OF TANK 241-S-104}

Appendix B provides sampling and analysis information for each known sampling event for tank 241-S-104 and provides an assessment of the core sample results.

- Section B1: Tank Sampling Overview

- Section B2: Analytical Results

- Section B3: Assessment of Characterization Results

- Section B4: References for Appendix B.

Future sampling of tank 241-S-104 will be appended to the above list.

\section{B1.0 TANK SAMPLING OVERVIEW}

This section describes the July 1992 sampling and analysis events for tank 241-S-104 core samples. These events were conducted as part of an overall plan to characterize the wastes in all underground storage tanks on the Hanford Site. The results of these analyses provide support for Tank Farm Operations and various other safety programs, aid in design of retrieval, pretreatment and disposal systems, and fulfill milestones contained in the Tri-Party Agreement (Bell 1994). Analytical data are available from two historical sampling events. The first sample was taken from tank 241-S-104 in 1974 (Wheeler 1974) and the second in was taken in 1976 (Horton 1976). These sample events are discussed in Section B1.4.

\section{B1.1 DESCRIPTION OF SAMPLING EVENT}

Samples were collected by push mode core sampling on July 29 and 30,1992 from riser 3 (core 42), July 31 from riser 7 (core 43), and August 2 from riser 2 (core 44). Each core contained 6 segments. An additional segment, 6R, was taken for core 42. Normal paraffin hydrocarbon was used as the hydrostatic head fluid. For a diagram of riser locations, refer to Figure A2-2. Table B1-1 lists tank farm sample numbers, with the dates and sampling locations.

The core samples from tank 241-S-104 were obtained using a core sampling truck that has sampling equipment mounted on a rotating platform. A stainless-steel sampler was used to obtain a 48-cm (19-in.)-long and 2.5-cm (1-in.)-diameter core of waste (maximum volume of 
$187 \mathrm{~mL}$ ). When the segment was captured within the sampler, it was sealed in a stainless-steel liner within a shipping cask to prevent sample liquid from being lost.

Although DQOs had not been formulated prior to this sampling event, the sampling locations and numbers would meet the requirements of the current DQOs. The sampling riser locations were separated radially to the maximum extent possible, and a full vertical profile of the waste was obtained from all three cores.

Table B1-1. Tank 241-S-104 Sample Numbers and Locations.

\begin{tabular}{|c|c|c|c|c|c|c|}
\hline 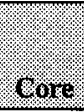 & $\mathrm{nH}_{\mathrm{S}}$ & 6. & 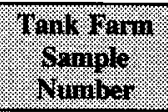 & 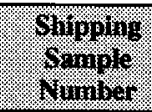 & ton. & Dois oringled \\
\hline 42 & 3 & 1 & $92-033$ & S92-018 & $1001 \mathrm{C}$ & $7-29-92$ \\
\hline 42 & 3 & 2 & $92-034$ & S92-018 & $\mathrm{C} 1053$ & $7-29-92$ \\
\hline 42 & 3 & 3 & $92-035$ & S92-018 & C1017 & $7-29-92$ \\
\hline 42 & 3 & 4 & $92-036$ & S92-019 & $1012 \mathrm{C}$ & $7-29-92$ \\
\hline 42 & 3 & 5 & $92-037$ & S92-019 & $\mathrm{C} 1042$ & $7-29-92$ \\
\hline 42 & 3 & 6 & $92-038$ & \$92-019 & $1003 \mathrm{C}$ & $7-30-92$ \\
\hline 42 & 3 & 6R & 92-038R & S92-020 & $\mathrm{C} 1046$ & $7-30-92$ \\
\hline 43 & 7 & 1 & $92-039$ & S92-016 & $\mathrm{C} 1047$ & $7-31-92$ \\
\hline 43 & 7 & 2 & $92-040$ & S92-016 & $\mathrm{C} 1033$ & $7-31-92$ \\
\hline 43 & 7 & 3 & $92-041$ & S92-016 & C1049 & $7-31-92$ \\
\hline 43 & 7 & 4 & $92-042$ & S92-017 & $1009 \mathrm{C}$ & $7-31-92$ \\
\hline 43 & 7 & 5 & $92-043$ & S92-017 & $\mathrm{C} 1024$ & $7-31-92$ \\
\hline 43 & 7 & 6 & $92-044$ & S92-017 & C1032 & $7-31-92$ \\
\hline 44 & 2 & 1 & $92-045$ & S92-013 & C1019 & $8-02-92$ \\
\hline 44 & 2 & 2 & $92-046$ & \$92-013 & $\mathrm{C} 1027$ & $8-02-92$ \\
\hline 44 & 2 & 3 & $92-047$ & S92-013 & $\mathrm{C} 1025$ & $8-02-92$ \\
\hline 44 & 2 & 4 & $92-048$ & S92-014 & $1013 C$ & $8-02-92$ \\
\hline 44 & 2 & 5 & $92-049$ & S92-014 & $1011 \mathrm{C}$ & $8-02-92$ \\
\hline 44 & 2 & 6 & $92-050$ & S92-014 & $\mathrm{C} 1030$ & $8-02-92$ \\
\hline \multicolumn{4}{|c|}{ Water samples } & S92-015 & $1005 \mathrm{C}$ & \\
\hline
\end{tabular}




\section{B1.2 SAMPLE HANDLING}

Each sampler segment was remotely removed from the drill string, sealed within a stainless-steel liner, and placed inside a lead-shielded shipping cask. The segment number was recorded and the casks were transported to the 222-S Laboratory. All the segments were received by the laboratory on August 6 and 7, 1992. A chain-of-custody form was completed for each segment.

The samples were extruded at the 222-S Laboratory between August 11 and September 11, 1992 in preparation for inorganic and radiochemical analyses.

The samples obtained from core sampling activities in tank 241-S-104 were a mixture of air, liquids, and solids. After extrusion from the sampler, photographs were taken of the sample with the appropriate jar numbers and color chart showing in the same photograph. Visual characteristics of extruded samples were recorded in the appropriate log book, and careful attention was paid to sample volume, liquid/solid ratio, color, consistency, and homogeneity. Table B1-2 contains a description of the contents of each core segment (Kocher 1993).

Twenty-seven composite and segment samples were shipped to the Pacific Northwest National Laboratory for organic analysis. The samples received included subsamples of the composites, segments from the three cores, a field blank, and a 222-S Hot Cell blank.

Tables B1-3 and B1-4 show the Westinghouse Hanford Company's 222-S Laboratory and Pacific Northwest Laboratory sample numbers that correspond to the various composite and segment sample numbers. In Table B1-3, the heading "Percent Water" is included because the samples were used exclusively for the percent water determination. Whereas most other physical analyses were performed prior to homogenization, percent water was determined after homogenization and prior to separation of the sample into the solid and liquid fractions in preparation for performing the metal, ion, and radionuclide analyses. 
HNF-SD-WM-ER-370 Rev. 1

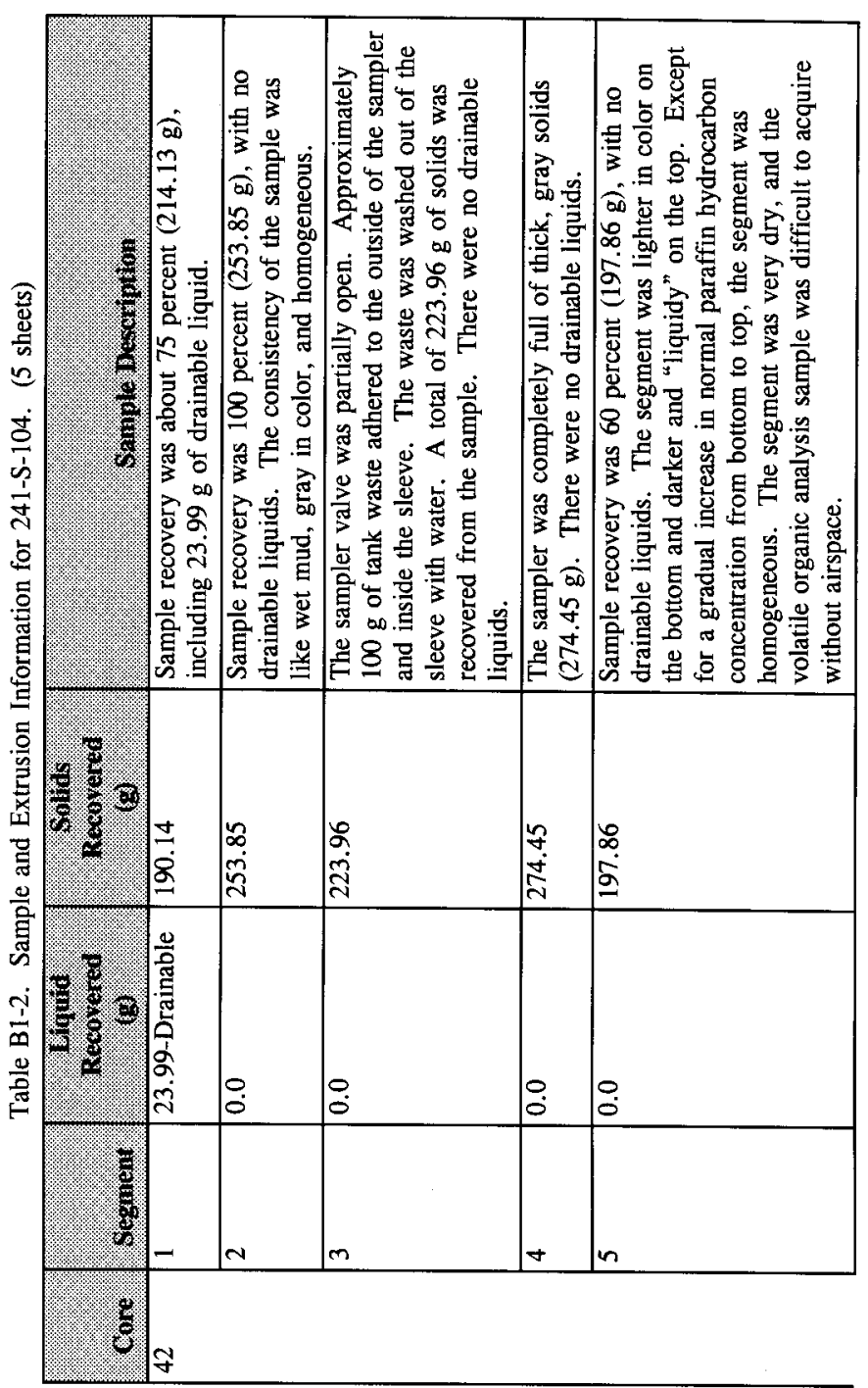


Table B1-2. Sample and Extrusion Information for 241-S-104. (5 sheets)

\begin{tabular}{|c|c|c|c|c|}
\hline Core & Segment & $\begin{array}{l}\text { Whing } \\
\text { Reconvered } \\
(0)\end{array}$ & $\begin{array}{l}\text { Solides } \\
\text { Recoverted } \\
\text { (a) }\end{array}$ & Sample Dacrofiption. \\
\hline & 6 & 0.0 & 96.95 & $\begin{array}{l}\text { The sampler valve was left open. The sample was } \\
1 / 3 \text { full of light gray solids ( } 96.95 \mathrm{~g} \text { ). There were no } \\
\text { drainable liquids. After sampling for weight percent } \\
\text { water, segment } 6 \text { was blended with } 6 \mathrm{R} \text { (below). }\end{array}$ \\
\hline \begin{tabular}{|l|}
42 \\
(Cont'd)
\end{tabular} & $6 \bar{R}$ & 0.0 & 60.07 & $\begin{array}{l}\text { Sampler recovery was about } 10 \text { percent }(60.07 \mathrm{~g}) \text {, with } \\
\text { no drainable liquids. The solids were a light gray, very } \\
\text { thick, and slightly moist. The waste was homogeneous, } \\
\text { though with more normal paraffin hydrocarbon at the top } \\
\text { of the segment. Approximately } 100 \mathrm{~mL} \text { of liner liquid, } \\
\text { which appeared to be normal paraffin hydrocarbon, was } \\
\text { collected and discarded. }\end{array}$ \\
\hline \multirow[t]{2}{*}{43} & 1 & 32.93 & 154.32 & $\begin{array}{l}\text { Sample recovery was } 75 \text { percent }(187.25 \mathrm{~g}) \text { and } \\
\text { contained about } 30 \mathrm{~mL} \text { of drainable liquids }(32.93 \mathrm{~g}) \text {. } \\
\text { Approximately } 25 \mathrm{~g} \text { of solids were at the surface, } \\
\text { followed by approximately } 50 \mathrm{~mL} \text { of liquid. After this, } \\
\text { there were solids to the top of the sample. Solids were } \\
\text { liquidy, especially in the middle. A differential scanning } \\
\text { calorimeter/thermogravimetric analysis was taken from } \\
\text { the solids at the top. The solids possessed the } \\
\text { consistency of butter and were gray-brown in color. }\end{array}$ \\
\hline & 2 & 0.0 & 266.58 & $\begin{array}{l}\text { Sample recovery was } 100 \text { percent }(266.58 \mathrm{~g}) \text {, with no } \\
\text { drainable liquids. The waste was gray, thicker at the } \\
\text { bottom than at the top, appeared to be completely } \\
\text { homogeneous, and possessed the consistency of wet mud. } \\
\text { Gas bubbles accounted for about } 2 \text { percent of the total } \\
\text { volume. }\end{array}$ \\
\hline
\end{tabular}


HNF-SD-WM-ER-370 Rev. 1

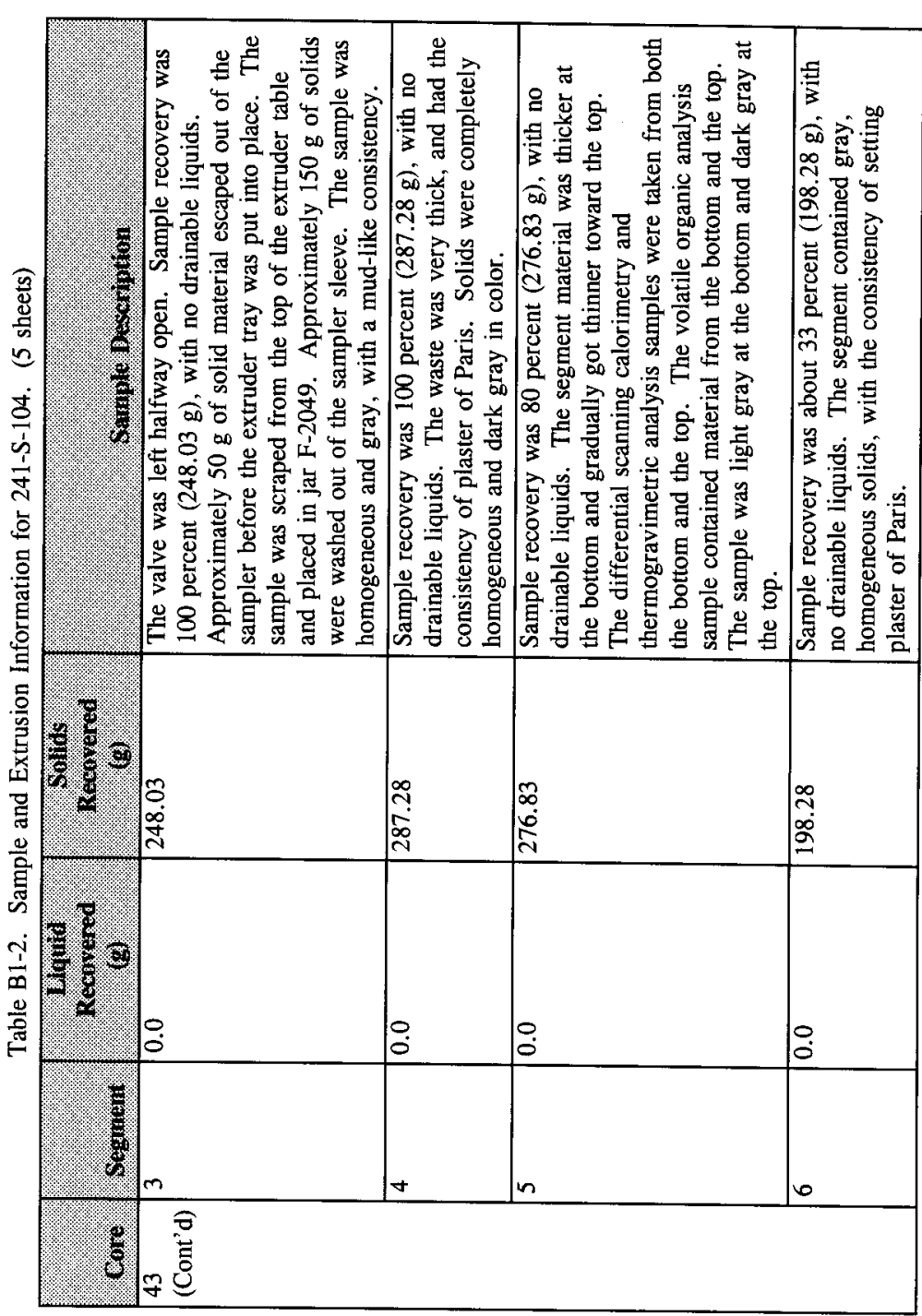




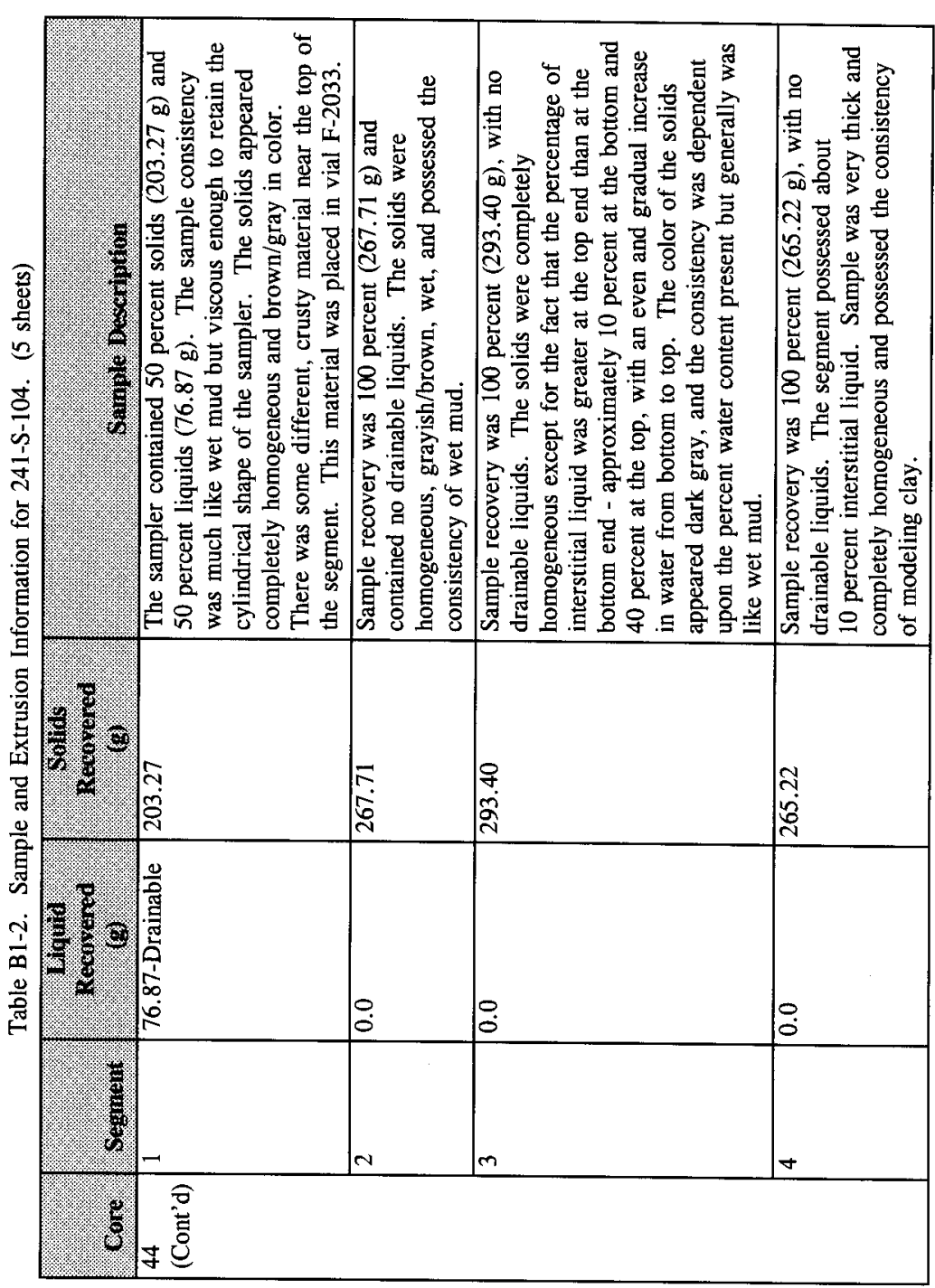


Table B1-2. Sample and Extrusion Information for 241-S-104. (5 sheets)

\begin{tabular}{|c|c|c|c|c|}
\hline (6ore: & Segrisur: & $\begin{array}{l}\text { Giguid } \\
\text { Treavered } \\
(\mathrm{g})\end{array}$ & $\begin{array}{l}\text { Soldis: } \\
\text { Recovered } \\
(1) \\
(1)\end{array}$ & Somal Bescin tiun \\
\hline \multirow[t]{2}{*}{$\begin{array}{l}44 \\
\text { (Cont'd) }\end{array}$} & 5 & 0.0 & 176.58 & $\begin{array}{l}\text { Sample recovery was about } 33 \text { percent }(176.58 \mathrm{~g}) \text { and } \\
\text { contained no drainable liquids. The sample was } \\
\text { homogeneous, gray, and very thick, like modeling clay. }\end{array}$ \\
\hline & 6 & 0.0 & 172.22 & $\begin{array}{l}\text { Sample recovery was about } 50 \text { percent }(172.22 \mathrm{~g}) \text {, with } \\
\text { no drainable liquids. Solids appeared to contain about } \\
12 \text { percent moisture. The material was light brown/tan, } \\
\text { crackly, and rigid like plaster of Paris, but not as } \\
\text { adhesive. There were light and dark areas on the surface } \\
\text { of the solids. While the light and dark areas were not } \\
\text { very pronounced, the solids were not perfectly } \\
\text { homogeneous. There was a } 23-\mathrm{cm} \text { (9-in.) void at the } \\
\text { bottom of the sampler. }\end{array}$ \\
\hline
\end{tabular}


Table B1-3. Tank 241-S-104 Composite and Liquid Tracking Numbers from the 222-S Laboratory.

\begin{tabular}{|c|c|c|c|}
\hline & \$ollo & Wroto & porocin \\
\hline Core 42 Composite 1 & F2171 & F2247 & F2199 \\
\hline Core 42 Composite 2 & F2172 & & F2201 \\
\hline Core 43 Composite 1 & F2175 & F2249 & $\mathrm{F} 2203$ \\
\hline Core 43 Composite 2 & F2176 & & $\mathrm{F} 2205$ \\
\hline Core 44 Composite 1 & $\mathrm{~F} 2177$ & $F 2248$ & \\
\hline Core 44 Composite 2 & F2178 & & $\mathrm{F} 2210$ \\
\hline
\end{tabular}

Table B1-4. Tank 241-S-104 Sample Numbers from Pacific Northwest Laboratory. (2 sheets)

\begin{tabular}{|c|c|c|}
\hline . & 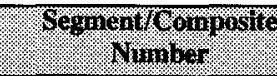 & 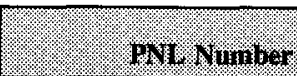 \\
\hline \multirow[t]{8}{*}{42} & Segment 1 & $93-01071$ \\
\hline & Segment 2 & $93-01072$ \\
\hline & Segment 3 & $93-01073$ \\
\hline & Segment 4 & 93-01753 \\
\hline & Segment 5 & 93-01074 \\
\hline & Segment 6R & $93-01075$ \\
\hline & Composite I & $93-01756$ \\
\hline & Composite 2 & $93-01076$ \\
\hline \multirow[t]{9}{*}{$\overline{43}$} & Segment 1 & $93-01750$ \\
\hline & Segment 2 & $93-01751$ \\
\hline & Segment 3 & 93-01068 \\
\hline & Segment 4 & 93-01752 \\
\hline & Segment 5 & $93-01069$ \\
\hline & Segment 6 & $93-01070$ \\
\hline & Segment 6R & $93-01755$ \\
\hline & Composite 1 & 93-01757 \\
\hline & Composite 2 & $93-01758$ \\
\hline
\end{tabular}


Table B1-4. Tank 241-S-104 Sample Numbers from Pacific Northwest Laboratory. (2 sheets)

\begin{tabular}{|c|c|c|}
\hline corr Vuniner. & $\begin{array}{l}\text { Segmentrlo oinposite } \\
\text { number }\end{array}$ & MH. Numuer \\
\hline \multirow[t]{10}{*}{44} & Segment 1 & $93-01067$ \\
\hline & Segment 2 & 93-01066 \\
\hline & Segment 3 & $93-01065$ \\
\hline & Segment 5 & 93-01064 \\
\hline & Segment 6 & 93-01815 \\
\hline & Segment 6R & $93-01754$ \\
\hline & Composite 1 & 93-01759 \\
\hline & Composite 2 & $93-01760$ \\
\hline & Hot cell blank & 93-01077 \\
\hline & Field blank & $93-01078$ \\
\hline
\end{tabular}

\section{B1.3 SAMPLE ANALYSES}

The requested analytes from the 222-S Laboratory are listed in Table B1-5. From the Pacific Northwest Laboratory, the requested analyses were volatile organic analysis, rheology, $\mathrm{Pu}$ and $U$ isotopic, extractable halides, and semi-volatile analysis. These samples and the requested analyses are shown below (Kocher 1993).

Volatile organic analysis:

Core 42, Segments 1, 3, 5

Core 43, Segments 1, 2, 3, 4, 5, 6

Core 44, Segments 1, 2, 3, 5, 6 .

Semi-volatile organic analysis and extractable organic halides:

Core 42, Composites 1, 2

Core 43, Composites 1,2

Core 44, Composites 1, 2.

Pu and $U$ isotopic:

Core 42, Composites 1,2 and segment $6 \mathrm{R}$

Core 43, Composites 1, 2 and segment $6 R$

Core 44, Composites 1, 2 and segment 6R. 
Volatile and semi-volatile organic analyses:

Hot cell blank

Field blank.

Rheology and physical:

Core 42, Segments 2, 4 .

Table B1-5. Tank 241-S-104 Samples and Requested Analytes.

\begin{tabular}{|c|c|}
\hline 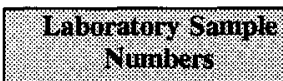 & hor \\
\hline $\begin{array}{l}\text { F2247, F2249, F2248, } \\
\text { F2199, F2201, F2203, } \\
\text { F22-05, F2210 }\end{array}$ & $\begin{array}{l}\mathrm{Al}, \mathrm{Sb}, \mathrm{As}, \mathrm{Ba}, \mathrm{Be}, \mathrm{Bi}, \mathrm{B}, \mathrm{Cd}, \mathrm{Ca}, \mathrm{Ce}, \mathrm{Cr}, \mathrm{Co}, \mathrm{Cu}, \mathrm{Fe}, \mathrm{La} \text {, } \\
\mathrm{Pb}, \mathrm{Mg}, \mathrm{Mn}, \mathrm{Ni}, \mathrm{P}, \mathrm{K}, \mathrm{Se}, \mathrm{Si}, \mathrm{Ag}, \mathrm{Na}, \mathrm{Sr}, \mathrm{S}, \mathrm{Sn}, \mathrm{Ti}, \mathrm{Zn}, \mathrm{Zr} \text {, } \\
\mathrm{NH}_{3}, \mathrm{CO}_{3}{ }^{2-}, \mathrm{Cl}^{-} \mathrm{CN}^{-}, \mathrm{F}^{-}, \mathrm{NO}_{3}^{-}, \mathrm{NO}_{2}^{-}, \mathrm{PO}_{4}{ }^{3-}, \mathrm{SO}_{4}{ }^{2-},{ }^{241} \mathrm{Am},{ }^{137} \mathrm{Cs} \text {, } \\
{ }^{60} \mathrm{Co},{ }^{154} \mathrm{Eu},{ }^{155} \mathrm{Eu},{ }^{239 / 240} \mathrm{Pu},{ }^{79} \mathrm{Se},{ }^{90} \mathrm{Sr} \text {, Total alpha, Total beta, } \% \\
\text { Water, } \mathrm{pH}, \mathrm{TGA}, \mathrm{TOC}, \mathrm{DSC}, \mathrm{OH}, \mathrm{SpG}\end{array}$ \\
\hline $\begin{array}{l}\mathrm{F} 2171, \mathrm{~F} 2172, \mathrm{~F} 2175, \\
\mathrm{~F} 2176, \mathrm{~F} 2177, \mathrm{~F} 2178\end{array}$ & $\begin{array}{l}\mathrm{Al}, \mathrm{Sb}, \mathrm{As}, \mathrm{Ba}, \mathrm{Be}, \mathrm{Bi}, \mathrm{B}, \mathrm{Cd}, \mathrm{Ca}, \mathrm{Ce}, \mathrm{Cr}, \mathrm{Co}, \mathrm{Cu}, \mathrm{Fe}, \mathrm{La}, \\
\mathrm{Pb}, \mathrm{Mg}, \mathrm{Mn}, \mathrm{Hg}, \mathrm{Ni}, \mathrm{P}, \mathrm{K}, \mathrm{Se}, \mathrm{Si}, \mathrm{Ag}, \mathrm{Na}, \mathrm{Sr}, \mathrm{S}, \mathrm{Sn}, \mathrm{Ti}, \mathrm{U}, \\
\mathrm{Zn}, \mathrm{Zr}, \mathrm{NH}_{3}, \mathrm{CO}_{3}^{2-}, \mathrm{Cl}^{-} \mathrm{CN}, \mathrm{F}^{-}, \mathrm{NO}_{3}^{-}, \mathrm{NO}_{2}^{-}, \mathrm{PO}_{4}^{3-}, \mathrm{SO}_{4}^{2-} \\
{ }^{241} \mathrm{Am},{ }^{14} \mathrm{C},{ }^{137} \mathrm{Cs},{ }^{60} \mathrm{Co},{ }^{154} \mathrm{Eu},{ }^{155} \mathrm{Eu},{ }^{129} 1,{ }^{237} \mathrm{~Np},{ }^{238} \mathrm{Pu},{ }^{239 / 240} \mathrm{Pu} \text {, } \\
{ }^{79} \mathrm{Se},{ }^{90} \mathrm{Sr},{ }^{99} \mathrm{Tc},{ }^{3} \mathrm{H} \text {, Total alpha, Total beta, pH, TGA, TOC }\end{array}$ \\
\hline
\end{tabular}

Notes:

$\begin{array}{lll}\mathrm{OH} & = & \text { free hydroxide } \\ \mathrm{pH} & = & \text { hydrogen potential } \\ \mathrm{SpG} & = & \text { specific gravity }\end{array}$

\section{B1.3.1 Sample Preparation}

When a sample contained more than $25 \mathrm{~mL}$ of drainable liquid, the liquid was analyzed separately from the solids. When the volume of the liquid was less than $25 \mathrm{~mL}$, a determination was made whether the liquid sample was actually normal paraffin hydrocarbon. When it was found to be normal paraffin hydrocarbon, it was drained off. When the liquid was not normal paraffin hydrocarbon, it was retained with the sample for eventual homogenization. For a further discussion of sample preparation procedures, see the Tank Characterization Reference Guide (De Lorenzo et al. 1994). 


\section{B1.3.2 Analytical Methods}

This section lists the analytes and the respective analytical procedures that were used to characterize the waste in tank 241-S-104. Procedures for physical, and rheological analyses are listed in Table B1-6. Procedures for inorganic and radiochemical analyses are listed in Table B1-7. Procedures for organic analyses are listed in Table B1-8. Two composites from each core were analyzed in accordance with the complete baseline case core composite scenario detailed in Winters et al. (1990) and as amended by Hill (1991). Several of the analytical tests performed on the composites were also done on the segments, but only for those analytes of importance to a program. Because the drainable liquids obtained were not enough to perform all the analyses requested, only highest priority analyses were performed and no duplicate analyses were run on the liquid composite.

Table B1-6. Analytical Methods for Physical and Rheological Tests.

\begin{tabular}{|l|l|}
\hline Shear strength & \\
\hline Shear stress/shear rate & PNL-ALO-501 \\
\hline Weight percent solids & PNL-ALO-501/502 \\
\hline Particle size & PNL-ALO-504 \\
\hline TGA & T044-A-01712F \\
\hline DSC & LA-560-112 \\
\hline SpG & LA-514-113 \\
\hline Weight percent water & LA-510-112 \\
\hline pH & LA-564-101 \\
\hline Settling velocity & LA-212-103 \\
\hline Settling behavior & PNL-ALO-501 \\
\hline
\end{tabular}

Table B1-7. Analytical Methods for Chemical and Radiochemical Analyses. (2 sheets)

\begin{tabular}{|l|l|l|}
\hline & & Troediure \\
\hline $\mathrm{F}^{-} \mathrm{Cl}^{-}, \mathrm{NO}_{2}^{-}, \mathrm{NO}_{3}{ }^{-}, \mathrm{PO}_{4}{ }^{-2}, \mathrm{SO}_{4}{ }^{2-}$ & Ion chromatography & LA-533-105 \\
\hline $\mathrm{NO}_{2}^{-}$ & Spectrophotometry & LA-645-001 \\
\hline $\mathrm{NH}_{3}$ & Kjeldahl & LA-634-102 \\
\hline $\mathrm{OH}^{-}$ & Titration & LA-212-103 \\
\hline
\end{tabular}


Table B1-7. Analytical Methods for Chemical and Radiochemical Analyses. (2 sheets)

\begin{tabular}{|c|c|c|}
\hline \%ngle & Wow10\% & $10 \% 0010$ \\
\hline $\mathrm{CN}^{-}$ & Distillation/spectrophotometric & LA-695-102 \\
\hline As, $\mathrm{Se}$ & GHAA $^{2}$ & LA-355-131 \\
\hline $\mathrm{Hg}$ & CVAA $^{3}$ & LA-325-102 \\
\hline Total metals & $\overline{\mathrm{ICP}} / \mathrm{AES}$ & LA-505-151 \\
\hline$\overline{\mathrm{U}}$ & Laser fluorimetry & LA-925-106 \\
\hline${ }^{60} \mathrm{Co},{ }^{137} \mathrm{Cs},{ }^{154} \mathrm{Eu},{ }^{155} \mathrm{Eu},{ }^{241} \mathrm{Am}$ & Gamma energy analysis & LA-548-121 \\
\hline${ }^{238} \mathrm{Pu},{ }^{239 / 240} \mathrm{Pu},{ }^{241} \mathrm{Am}$ & Separation/Alpha/AEA & LA-503-156 \\
\hline $\begin{array}{l}{ }^{14} \mathrm{C} \\
{ }^{3} \mathrm{H} \\
{ }^{79} \mathrm{Se} \\
{ }^{99} \mathrm{Tc}\end{array}$ & Liquid scintillation & $\begin{array}{l}\text { LA-348-104 } \\
\text { LA-218-113 } \\
\text { LA-365-132 } \\
\text { LA-438-101 }\end{array}$ \\
\hline${ }^{90} \mathrm{Sr}$ & Separation $/$ beta $^{2}$ & LA-220-101 \\
\hline${ }^{129} I$ & Gamma energy analysis & LA-378-101 \\
\hline${ }^{237} \mathrm{~Np}$ & Alpha proportional counting & LA-933-141 \\
\hline${ }^{244} \mathrm{Cm}$ & Separation/alpha/AEA ${ }^{3}$ & LA-508-051 \\
\hline Total alpha & Proportional counting & LA-508-101 \\
\hline $\mathrm{CO}_{3}^{-2} / \mathrm{C}$ & Total inorganic carbon & LA-622-102 \\
\hline TOC & Total organic carbon & LA-344-105 \\
\hline Pu Isotopic & Fusion/mass spectrometry & $\begin{array}{l}\text { PNL-ALO-423 } \\
\text { PNL-MA-597 }\end{array}$ \\
\hline U Isotopic & Mass spectrometry & PNL-ALO-445 \\
\hline Total beta & Proportional counting & LA-508-101 \\
\hline
\end{tabular}

Notes:
AEA $=$ alpha energy analysis
AES $=$ atomic emission spectroscopy
CVAA $=$ cold vapor atomic absorption spectrometry
ICP $=$ inductively coupled plasma
GHAA = gaseous hydride atomic absorption spectrometry

'Ammonia analysis by caustic addition, distillation, and capture in a boric acid solution

${ }^{2}$ Chemical separation along with total beta proportional counting

${ }^{3}$ Chemical separation along with alpha proportional counting and alpha energy analysis. 
Table B1-8. Analytical Methods for Organic Analyses.

\begin{tabular}{|c|c|c|}
\hline 1nabris & Metbod & Prosedine. \\
\hline Volatile organic & Gas chromatography/mass spectrometry & PNL-ALO-335 \\
\hline Semi-volatile organic & Gas chromatography/mass spectrometry & PNL-ALO-345 \\
\hline Extractable organic halides & Microcoulometric titration & PNL-ALO-320.2 \\
\hline Total organic halides & Microcoulometric titration & PNL-ALO-321 \\
\hline
\end{tabular}

\section{B1.3.3 Physical and Rheological Tests}

Physical and rheological tests were conducted at the Pacific Northwest National Laboratory on segments 2 and 4 of core 42 of tank 241-S-104 core samples. The rheological testing on these samples included shear strength and shear stress, both as a function of shear rate. Physical properties measured settling behavior, density, weight percent solids and weight percent dissolved solids. Settling behavior measurements included volume percent settled solids and both weight percent and volume percent centrifuged solids. The settling velocity and volume percent settled solids measurements were performed on 1:1 and 3:1 water:sample dilutions.

Physical tests completed at 222-S Laboratory included particle size analysis, TGA, DSC, $\mathrm{SpG}$, and percent water analyses. Table B1-6 lists the analytical methods used for physical and rheological properties.

\section{B1.3.4 Chemical and Radionuclide Constituent Analysis}

Chemical and radionuclide analyses were performed at the 222-S Laboratory and at the Pacific Northwest National Laboratory. Duplicate analyses were performed on every sample. Table B1-7 lists the analytical methods used.

Quality control procedures were conducted in accordance with the requirements listed in Bell (1994). In summary, those requirements are:

- One laboratory control standard per analytical batch

- One blank per batch

- One matrix spike per core per matrix

- 100 percent duplicates on all homogenization test samples and core composite samples 
- One duplicate per analytical batch for direct segment samples

- A duplicate to verify each detected exotherm for DSC analysis.

Exceptions are allowed for specific analytes or procedures:

- Percent water is always run in duplicate

- $\quad{ }^{90} \mathrm{Sr},{ }^{79} \mathrm{Se},{ }^{99} \mathrm{Tc},{ }^{129} \mathrm{I}, \mathrm{Pu}$, and Am have a tracer or carrier added to each sample; no additional matrix spikes are required

- Gamma energy analysis and $\mathrm{pH}$ do not require a spike

- A matrix spike for $\mathrm{Np}$ is requested on each sample.

\section{B1.3.5 Organic Constituent Analysis}

All organic analyses of the samples from tank 241-S-104 were performed at the Pacific Northwest National Laboratory. A U.S. Environmental Protection Agency Contract Laboratory Procedure-type organics speciation analysis was performed on the core composites. The organic analyses performed were volatile, semi-volatile organic, and extractable organic halides. Duplicates were performed for all of these analyses. Table B1-8 lists the analyses and procedure numbers, and Table B1-4 lists the core and segment numbers used for the organic analyses.

\section{B1.4 DESCRIPTION OF HISTORICAL SAMPLING EVENT}

Sample T-4184, taken in 1974, was described as yellow in color, and contained 10 percent solids (Wheeler 1974). It appears to be a supernatant sample. No information was available regarding sample handling for this sampling event. Sludge sampling data for tank 241-S-104 have been obtained for one sample and were reported on February 24, 1976 (Horton 1976). The sample was reported as being the texture of a stiff dough or putty, with a tendency to be sticky, and was grayish in color. No information was available regarding sample handling for this sampling event.

The data are presented in Section B2.8. Pre-1989 analytical data have not been validated and should be used with caution. 


\section{B2.0 ANALYTICAL RESULTS}

\section{B2.1 OVERVIEW}

The chemical, radiochemical, and physical results associated with tank 241-S-104 are presented in this document as indicated in Table B2-1. The samples from which these results were derived were collected from July 29, 1992 through August 2, 1992. This sampling event was the most recent regarding tank $241-S-104$ and reflects the most accurate characterization of the tank waste available at the present time.

Table B2-1. Analytical Data Presentation Tables.

\begin{tabular}{|l|l|}
\hline Metals & Tlablor \\
\hline Anions & Tables B2-8 through B2-42 \\
\hline Radionuclides & Tables B2-46 through B2-54 \\
\hline Physical properties and miscellaneous chemical data & Tables B2-85 through B2-94 \\
\hline Volatile organics & Tables B2-101 through B2-105 \\
\hline Semivolatile organics & Tables B2-106 through B2-110 \\
\hline
\end{tabular}

The projected tank inventory value for tank $241-S-104$ was calculated by multiplying the mean analyte concentration by the volume of solid phase waste. The appropriate conversion factors were included in the calculations to obtain the reported units. The supernatant liquid was not included in the tank inventory estimate because of its small ( 0.34 percent) contribution to the waste volume.

\section{B2.2 METALS}

Sodium was the major metal constituent in the liquid phase of the waste and exhibited a concentration of $1.55 \mathrm{E}+05 \mu \mathrm{g} / \mathrm{g}$; aluminum and chromium concentrations exceeded $1,000 \mu \mathrm{g} / \mathrm{g}$ and were relatively high compared to other metals. Although analyzed, the following elements were not detected in the liquid portion of the tank waste: $\mathrm{As}, \mathrm{Ba}, \mathrm{Bi}, \mathrm{Ce}$, $\mathrm{Ni}, \mathrm{Se}, \mathrm{Ag}, \mathrm{Ti}$, and $\mathrm{Zr}$.

In the solid samples from tank 241-S-104, $\mathrm{Al}, \mathrm{Ca}, \mathrm{Cr}, \mathrm{Fe}, \mathrm{Mn}, \mathrm{Ni}, \mathrm{Si}, \mathrm{Na}$, and $\mathrm{U}$ were all detected in concentrations exceeding $1,000 \mu \mathrm{g} / \mathrm{g}$; however, of these, sodium and aluminum were by far the most abundant. Of the evaluated analytes, only $\mathrm{Be}, \mathrm{Bi}, \mathrm{La}$, and $\mathrm{Hg}$ were not 
detected in the solid samples. This is consistent with what is known about REDOX process chemistry and the transfer activity of this tank. The sample results for anions and other chemicals are given in Tables B2-8 through B2-42.

\section{B2.3 ANIONS}

The most abundant anion in both the liquid and solid phases of the waste was reported to be nitrate. However, judging from the liquid phase hydroxide concentration and the historical data, it is reasonable to assume that the solid phase contains a substantial amount of hydroxide salts, and possibly oxides as well. Ammonia was not present in the tank above detection limits. The sample results for anions and other chemicals are given in Tables B2-46 through B2-54.

\section{B2.4 RADIONUCLIDES}

\section{B2.4.1 Alpha Activity}

Analyses for total alpha activity were performed on the samples recovered from tank 241-S-104. The samples were analyzed according to procedure LA-508-101. The highest result determined was $0.957 \mu \mathrm{Ci} / \mathrm{g}$. The sample results for total alpha are given in Table B2-79 and Table B2-80, and the results are compared to the sum of the individual alpha isotopes in Table B2-81.

Separation and alpha energy analysis (AEA) were used to determine the ${ }^{238} \mathrm{Pu}$ and ${ }^{239 / 240} \mathrm{Pu}$ ratios for $\mathrm{Pu}$ and the ${ }^{241} \mathrm{Am}$ and ${ }^{243 / 244} \mathrm{Cm}$ ratios for $\mathrm{Am}$. These ratios were then used to report separate activities for each of the isotopes.

\section{B2.4.2 Mass Spectrometry}

Thermal ionization mass spectrometry was used to determine the presence of all isotopes of $\mathrm{Pu}$ and $\mathrm{U}$. Uranium and plutonium values were consistent with typical fuel burnup.

\section{B2.4.3 Total Beta Activity}

Analysis of the total beta activity was performed on the composite samples from cores after a fusion digestion. The total beta values were determined by drying a small aliquot of each solution and counting in a beta proportional counter. Tables B2-82 through B2-84 display the data for the total beta results for drainable liquid and solid composites and compare the beta results to the sum of individual beta-emitting isotopes. 


\section{B2.4.4 Gamma Energy Analysis}

A gamma energy analysis (GEA) was performed on core composite samples and homogenization test samples after fusion digestion. Results were obtained for ${ }^{241} \mathrm{Am},{ }^{60} \mathrm{Co}$, ${ }^{137} \mathrm{Cs},{ }^{154} \mathrm{Eu}$, and ${ }^{155} \mathrm{Eu}$. Not all of the listed radionuclides were measured in every sample. Tables B2-55 and B2-58 through B2-67 present the GEA data. ${ }^{129} \mathrm{I}$ is determined by separation and counting on a low-energy gamma system separate from other gamma isotopes.

\section{B2.4.5 Liquid Scintillation Counting}

Tritium was measured on core composite samples. Table B2-74 presents the tritium results. Liquid scintillation counting was also used to determine the concentration of ${ }^{79} \mathrm{Se}$. The ${ }^{79} \mathrm{Se}$ results are presented in Table B2-71. The ${ }^{14} \mathrm{C}$ and ${ }^{99} \mathrm{Tc}$ samples were counted with a scintillation counter. Results from this analysis are shown in Table B2-57 and B2-73, respectively.

\section{B2.5 PHYSICAL ANALYSES}

The physical measurements were primarily performed on core 42 , segments 2 and 4 . Results of the physical measurements are presented in Table B2-2. Particle size analysis was performed on cores 42,43 and 44 . Some physical properties were not measured on segment 4 because an accurate volume could not be measured on the centrifuged sample and no centrifuged supernatant was obtained.

Table B2-2. Tank 241-S-104, Core 42 Physical Measurements.

\begin{tabular}{|c|c|c|c|}
\hline 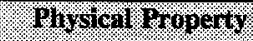 & & Qtgineni 2 & Seginenil 1 \\
\hline \multirow[t]{3}{*}{ Density $(\mathrm{g} / \mathrm{mL})$} & Sample & 1.64 & $\mathrm{n} / \mathrm{a}$ \\
\hline & Centrifuged supernatant & 1.28 & $\mathrm{n} / \mathrm{a}$ \\
\hline & Centrifuged solid & 1.71 & $\mathrm{n} / \mathrm{a}$ \\
\hline \multirow[t]{3}{*}{ Settled solids } & \multirow[t]{3}{*}{ Vol\% } & 100 (no dilution) & 100 (no dilution) \\
\hline & & 88 ( $1: 1$ dilution) & 100 (1:1 dilution) \\
\hline & & 60 (3:1 dilution) & 80 (3:1 dilution) \\
\hline \multirow[t]{2}{*}{ Centrifuged solids } & wt \% solids & 62.3 & 67.7 \\
\hline & wt \% undissolved solids & 55.4 & $n / a$ \\
\hline
\end{tabular}

Note:

'Kocher (1993) 


\section{B2.5.1 Density and Percent Solids}

The density measurement was performed on segment 2 only. The overall sample density was $1.64 \mathrm{~g} / \mathrm{mL}$. The centrifuged supernatant density was determined to be $1.28 \mathrm{~g} / \mathrm{mL}$ and the centrifuged solid density was $1.71 \mathrm{~g} / \mathrm{mL}$.

The volume percent settled solids measured on the as-received segments did not exhibit settling over a 3-day period. Two dilutions (1:1 and 3:1 water to sample) were prepared for each of the segments. No settling was observed for the $1: 1$ dilution of segment 4 . The $3: 1$ dilution of segment 4 settled to a final volume percent of 80 . Segment 2 dilutions of $1: 1$ and $3: 1$ reached a final volume percent settled solids of 88 and 60 , respectively.

Weight percent of solids and undissolved solids was performed on the centrifuged samples. For wt \% solids segment 2 was 62.3 percent and segment 4 was 67.7 percent. Only segment 2 was measured for weight percent undissolved solids at 55.4 percent.

\section{B2.5.2 Particle Size}

Particle size analysis was performed using a particle size analyzer. The acquisition range was 0.5 to 150 microns. Table B2-3 summarizes the results of the analysis. The analysis reveals that 92 percent of the particles are between 0.5 to 2.0 microns in diameter and 83 percent of the particle volume is comprised of particles 2 to 150 microns in diameter.

Table B2-3. Summary of Particle Size Distribution for Tank 241-S-104.

\begin{tabular}{|c|c|c|c|c|}
\hline 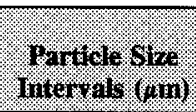 & Mondo & 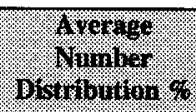 & 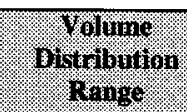 & \% \\
\hline $0.5-1.0$ & $52.2-86$ & 72.9 & $0-11.2$ & 3.53 \\
\hline $1-2$ & $11.2-27.6$ & 18.77 & $0-12.2$ & 6.24 \\
\hline $2-5$ & $0.8-10.3$ & 5.83 & $2.2-42.4$ & 23.14 \\
\hline $5-10$ & $0.6-5.4$ & 2.06 & $1.4-33.6$ & 15.23 \\
\hline $10-20$ & $2-3$ & 0.38 & $1.4-32.6$ & 15.23 \\
\hline $20-50$ & 0 & 0 & $5-30$ & 15.09 \\
\hline $50-150$ & 0 & 0 & $0-80$ & 14.58 \\
\hline
\end{tabular}




\section{B2.5.3 Rheology}

Shear stress as a function of shear rate was measured for $1: 1,1.3: 1$, and 3:1 dilutions of samples from core 42, segments 2 and 4. All dilutions for both segments exhibited yield psuedoplastic behavior, and their flow properties are presented in Table B2-4. Table B2-5 shows the power law curve fit parameters.

Table B2-4. Flow Properties. (2 sheets)

\begin{tabular}{|c|c|c|c|c|c|c|c|}
\hline & & & & & (2) & Yrofical & \\
\hline Ge.joner & $\begin{array}{l}\text { Gilition } \\
\text { Wuler } \\
\text { Sampile }\end{array}$ & $\int_{0}^{T a n g}$ & Ruin & $\begin{array}{l}\text { Thyer } \\
\text { Bhaneters } \\
\text { ang (19) }\end{array}$ & 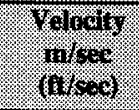 & 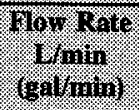 & $\begin{array}{l}\text { Qeynofids. } \\
\text { Number. }\end{array}$ \\
\hline 2 & $1: 1$ & 30 & 1 & $5.08(2)$ & $1.16(3.8)$ & $148(39)$ & 6,400 \\
\hline & & & & $7.62(3)$ & $1.04(3.4)$ & $295(78)$ & 7,600 \\
\hline & & & 2 & $5.08(2)$ & $1.07(3.5)$ & $140(37)$ & 7,200 \\
\hline & & & & $7.62(3)$ & $0.098(3.2)$ & $276(73)$ & 8,800 \\
\hline & & 95 & 3 & $5.08(2)$ & $0.88(2.9)$ & $114(30)$ & 7,900 \\
\hline & & & & $7.62(3)$ & $0.79(2.6)$ & $227(60)$ & 10,100 \\
\hline & & & 4 & $5.08(2)$ & $0.85(2.8)$ & $110(29)$ & 9,300 \\
\hline & & & & $7.62(3)$ & $0.76(2.5)$ & $220(58)$ & 11,500 \\
\hline & & 28 & 5 & $5.08(2)$ & $7.19(23.6)$ & $935(247)$ & 2,800 \\
\hline & & & & $7.62(3)$ & $6.07(19.9)$ & $1730(458)$ & 3,100 \\
\hline & & & 7 & $5.08(2)$ & $4.66(15.3)$ & $605(160)$ & 2,900 \\
\hline & & & & $7.62(3)$ & $4.08(13.4)$ & $1170(308)$ & 3,200 \\
\hline 4 & $1.3: 1$ & 30 & 1 & $5.08(2)$ & $2.59(8.5)$ & $337(89)$ & 31,100 \\
\hline & & & & $7.62(3)$ & $2.35(7.7)$ & $670(177)$ & 40,800 \\
\hline & & & 2 & $5.08(2)$ & $2.32(7.6)$ & $303(80)$ & 18,600 \\
\hline & & & & $7.62(3)$ & $2.10(6.9)$ & $598(158)$ & 24,600 \\
\hline & & 95 & 1 & $5.08(2)$ & $1.74(5.7)$ & $227(60)$ & 9,300 \\
\hline & & & & $7.62(3)$ & $1.55(5.1)$ & $447(118)$ & 11,900 \\
\hline & & & 2 & $5.08(2)$ & $1.58(5.2)$ & $204(54)$ & 11,100 \\
\hline & & & & $7.62(3)$ & $1.43(4.7)$ & $405(107)$ & 14,100 \\
\hline
\end{tabular}


HNF-SD-WM-ER-370 Rev. 1

Table B2-4. Flow Properties. (2 sheets)

\begin{tabular}{|c|c|c|c|c|c|c|c|}
\hline & & & & 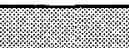 & 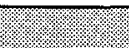 & Critiral & \\
\hline Szginent & 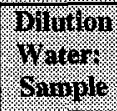 & 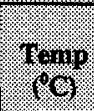 & Kian & 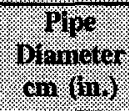 & 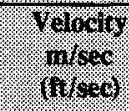 & $\begin{array}{l}\text { Thor Rate } \\
\text { I/min } \\
\text { griming }\end{array}$ & 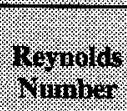 \\
\hline 2 & $3: 1$ & 30 & 1 & $5.08(2)$ & $0.73(2.4)$ & $95(25)$ & 6,600 \\
\hline & & & & $7.62(3)$ & $0.64(2.1)$ & $185(49)$ & 8,000 \\
\hline & & & 2 & $5.08(2)$ & $0.70(2.3)$ & $91(24)$ & 6,800 \\
\hline & & & & $7.62(3)$ & $0.64(2.1)$ & $182(48)$ & 8,400 \\
\hline & & 95 & 3 & $5.08(2)$ & $0.67(2.2)$ & $87(23)$ & 10,100 \\
\hline & & & & $7.62(3)$ & $0.61(2.0)$ & $174(46)$ & 13,300 \\
\hline & & & 4 & $5.08(2)$ & $0.67(2.2)$ & $87(23)$ & 10,400 \\
\hline & & & & $7.62(3)$ & $0.61(2.0)$ & $174(46)$ & 13,800 \\
\hline 4 & $3: 1$ & 30 & 1 & $5.08(2)$ & $1.37(4.5)$ & $178(47)$ & 6,200 \\
\hline & & & & $7.62(3)$ & $1.25(4.1)$ & $356(94)$ & 7,400 \\
\hline & & & 2 & $5.08(2)$ & $1.37(4.5)$ & $178(47)$ & 6,500 \\
\hline & & & & $7.62(3)$ & $1.25(4.1)$ & $356(94)$ & 7,700 \\
\hline & & 95 & 1 & $5.08(2)$ & $1.25(4.1)$ & \begin{tabular}{|l|}
$159(42)$ \\
\end{tabular} & 9,600 \\
\hline & & & & $7.62(3)$ & $1.10(3.6)$ & $314(83)$ & 12,500 \\
\hline & & & 2 & $5.08(2)$ & $1.22(4.0)$ & $155(41)$ & 6,900 \\
\hline & & & & $7.62(3)$ & $1.10(3.6)$ & $310(82)$ & 8,300 \\
\hline
\end{tabular}


Table B2-5. Power Law Curve Fit Parameters.

\begin{tabular}{|c|c|c|c|c|c|c|}
\hline Segrient & 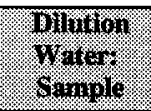 & $\begin{array}{l}\text { Temis } \\
(7 \%)\end{array}$ & irin & 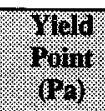 & 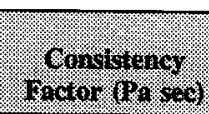 & $\begin{array}{l}\text { Goor: } \\
\text { Benuriox } \\
\text { mindox }\end{array}$ \\
\hline \multirow[t]{4}{*}{2} & \multirow[t]{4}{*}{ 1: 1} & \multirow[t]{2}{*}{30} & 1 & 3.60 & $4.07 \times 10^{-2}$ & 0.741 \\
\hline & & & 2 & 3.45 & $2.39 \times 10^{-2}$ & 0.810 \\
\hline & & \multirow[t]{2}{*}{95} & 3 & $\overline{2.42}$ & $1.01 \times 10^{-2}$ & 0.927 \\
\hline & & & 4 & 2.73 & $1.25 \times 10^{-2}$ & 0.834 \\
\hline \multirow[t]{6}{*}{4} & \multirow[t]{2}{*}{$1: 1$} & \multirow[t]{2}{*}{28} & 5 & 32.0 & $6.55 \times 10^{-1}$ & 0.792 \\
\hline & & & 7 & 14.1 & $9.26 \times 10^{-1}$ & 0.649 \\
\hline & \multirow[t]{4}{*}{$1.3: 1$} & \multirow[t]{2}{*}{30} & 1 & 17.2 & $9.96 \times 10^{-2}$ & 0.760 \\
\hline & & & 2 & 15.5 & $4.74 \times 10^{-2}$ & 0.842 \\
\hline & & \multirow[t]{2}{*}{95} & 3 & 10.4 & $1.66 \times 10^{-2}$ & 0.933 \\
\hline & & & 4 & 10.2 & $1.46 \times 10^{-2}$ & 0.902 \\
\hline \multirow[t]{4}{*}{2} & \multirow[t]{4}{*}{$3: 1$} & \multirow[t]{2}{*}{30} & 1 & 1.26 & $1.45 \times 10^{-2}$ & 0.812 \\
\hline & & & 2 & 1.26 & $1.23 \times 10^{-2}$ & 0.838 \\
\hline & & \multirow[t]{2}{*}{95} & 3 & 1.55 & $4.20 \times 10^{-3}$ & 0.981 \\
\hline & & & 4 & 1.59 & $3.78 \times 10^{-3}$ & 1.00 \\
\hline \multirow[t]{4}{*}{4} & \multirow[t]{4}{*}{$3: 1$} & \multirow[t]{2}{*}{30} & 1 & 4.35 & $4.26 \times 10^{-2}$ & 0.762 \\
\hline & & & 2 & 4.54 & $4.07 \times 10^{-2}$ & $0 . \overline{761}$ \\
\hline & & \multirow[t]{2}{*}{95} & 3 & 4.83 & $8.37 \times 10^{-3}$ & 0.974 \\
\hline & & & 4 & 3.77 & $2.97 \times 10^{-2}$ & 0.779 \\
\hline
\end{tabular}

\section{B2.5.4 Thermogravimetric Analysis}

Thermogravimetric analysis measures the mass of a sample while its temperature is increased at a constant rate. Nitrogen is passed over the sample during heating to remove any released gases. Any decrease in the weight of a sample during TGA represents a loss of gaseous matter from the sample, either through evaporation or through a reaction that forms gas phase products. The moisture content is estimated by assuming that all TGA sample weight loss up to a certain temperature (typically 150 to $200^{\circ} \mathrm{C}$ [300 to $\left.390{ }^{\circ} \mathrm{F}\right]$ ) is the result of water evaporation. The temperature limit for moisture loss is chosen by the operator at an inflection point on the TGA plot. Other volatile matter fractions can often be differentiated by inflection points as well. 
Tank 241-S-104 samples were analyzed by TGA using procedure LA-514-112, and the results are presented in Table B2-85. The weight percent water values for the segment samples were between 7.66 and 53.8. However, the weight percent water values for the core 44 composite samples were between 93.8 and 95.2 . The results from the core 44 composites are questionable because segment results were between 21.6 and 42.3 percent.

\section{B2.5.5 Differential Scanning Calorimetry}

In a DSC analysis, heat absorbed or emitted by the sample is measured while the sample is heated at a constant rate. Nitrogen is passed over the sample material to remove any gases being released. The onset temperature for an endothermic or exothermic event is determined graphically.

The DSC analyses for tank 241-S-104 were performed using procedure LA-514-313. No segment sample exceeded the safety screening DQO decision criteria of $-480 \mathrm{~J} / \mathrm{g}$. All the segment samples had no exotherms. However, the composite samples from cores 43 and 44 had exotherms. The core 43 composite result was $4.5 \mathrm{~J} / \mathrm{g}$ (wet weight basis), and the rerun showed no evidence of exotherms. The highest core 44 composite result was $74.3 \mathrm{~J} / \mathrm{g}$ (wet weight basis). However, this result is questionable because all the segments from core 44 showed no exotherms. Furthermore, the TGA water results for the core 44 composite were approximately 95 percent, which indicates that the analytical results from the core 44 composites are questionable.

\section{B2.6 ORGANIC CONSTITUENTS}

None of the target analytes associated with the volatile and semi-volatile organic analyses were detected, as indicated by Tables B2-101 and B2-110, during the evaluation of samples from tank 241-S-104. Because of their volatile nature and relatively small contribution to the waste as indicated by the historical records, the appearance of these compounds was not expected. The appearance of several normal paraffin hydrocarbons was reported by the laboratory as tentatively identified compounds, but these constituents may be the result of hydrostatic fluid contamination from the sampling process. Several silicone derivatives were also detected during the sample analyses. These compounds were most likely column degradation products, caused by the high $\mathrm{pH}$ of the sample matrix.

\section{B2.7 VAPOR PHASE MEASUREMENT}

A vapor phase measurement was taken on March 19, 1996 for tank 241-S-104. This measurement supported the safety screening DQO (Dukelow et al. 1995). The vapor phase screening was taken for flammability issues. The vapor phase measurements were taken $6 \mathrm{~m}$ 
(20 ft) below a riser in the headspace of the tank and results were obtained in the field (i.e., no gas sample was sent to the laboratory for analysis). The results of the vapor phase measurements are provided in Table B2-6.

Table B2-6. Results of Vapor Phase Measurements of Tank 241-S-104.

\begin{tabular}{|c|c|}
\hline & I. Result \\
\hline Mengirieninil. & 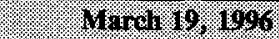 \\
\hline Total organic carbon (TOC) & $0 \mathrm{ppm}$ \\
\hline Lower explosive limit (LEL) & $0.0 \%$ of LEL \\
\hline Oxygen & $n / a$ \\
\hline Ammonia & $25 \mathrm{ppmv}$ \\
\hline
\end{tabular}

\section{B2.8 HISTORICAL SAMPLE RESULTS}

Analytical data from two historical sampling events of tank 241-S-104 are available. Sample T-4184, taken in 1974, was described as yellow with 10 percent solids (Wheeler 1974), and appears to be a supernatant sample. The results of the 1974 sample are shown in Table B2-7. Because supernatant was removed from tank 241-S-104 in transfers and salt well pumping after 1974 , this sample is likely not representative of the sludge that makes up nearly all of the tank waste. The analytical data for Sample T-4184 will thus not be further discussed in this report.

A sludge sampling from 1976 resulted in the sludge in tank 241-S-104 being described as grayish in color and sticky, with the consistency of stiff dough or putty (Horton 1976). These observations are consistent with contemporary observations. The results of the 1976 sample are shown in Table B2-7. These data have not been validated and should be used with caution. 
HNF-SD-WM-ER-370 Rev. 1

Table B2-7. Historical Sample. ${ }^{1}$

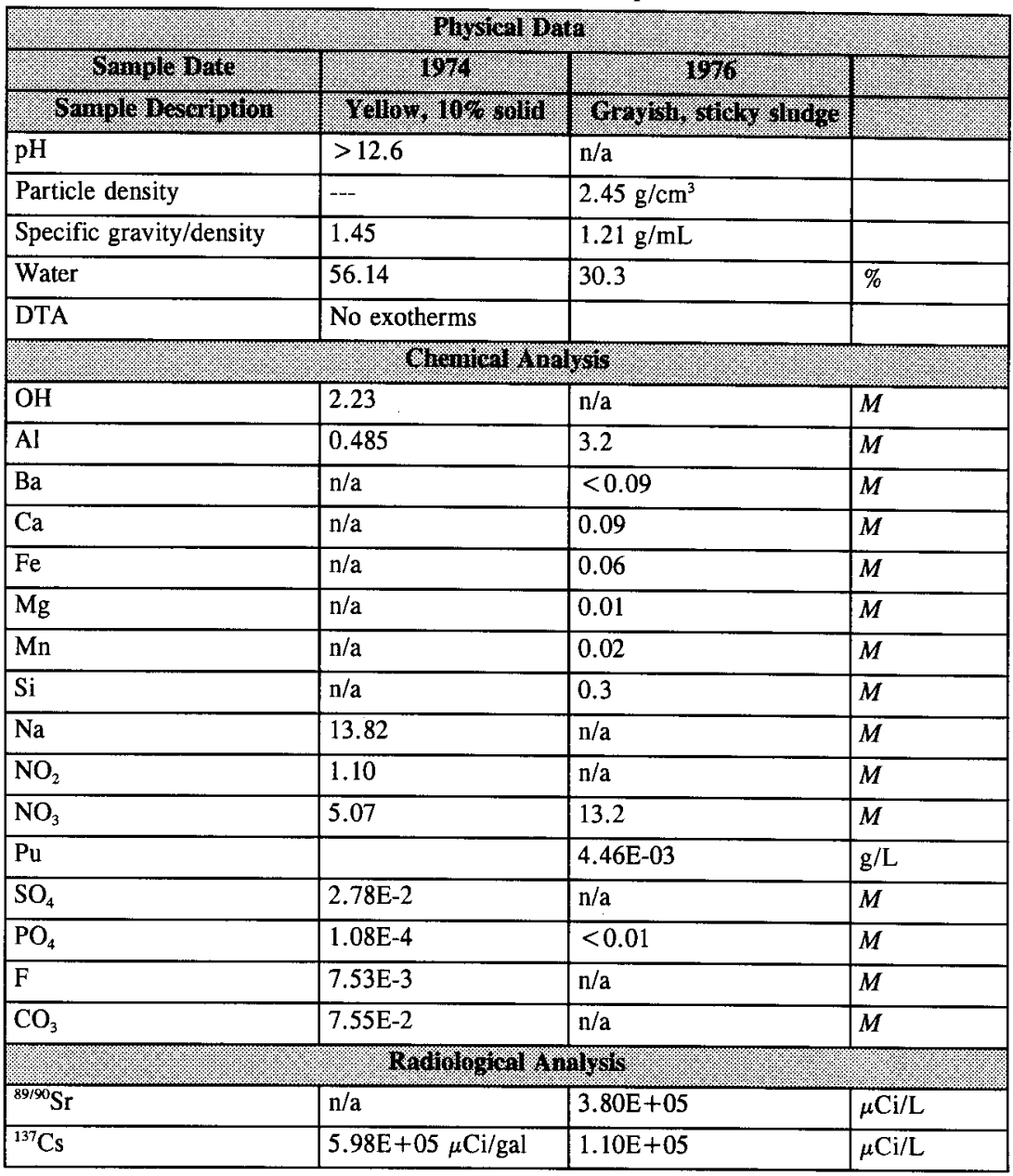

Notes:

DTA $=$ differential thermal analysis

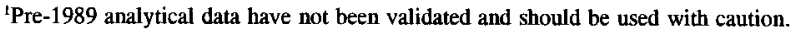




\section{B2.9 ANALYTICAL DATA TABLES}

For most analytes (except for some physical and rheological measurements), the data tables consist of six columns. The first column lists the sample number. Note that for each primary/duplicate pair, the sample number is for the primary result. The second column lists the core from which the samples were derived. The third column lists the sample portion from with the aliquots were taken. The final three columns display the primary and duplicate analytical values and a mean for each sample/duplicate pair.

Quality control $(\mathrm{QC})$ footnotes:

- a -- indicates that the standard recovery was below the $\mathrm{QC}$ range.

- $\quad b-$ indicates that the standard recovery was above the $\mathrm{QC}$ range.

- $\quad c$-- indicates that the spike recovery was below the QC range.

- $\quad d$-- indicates that the spike recovery was above the QC range.

- $\quad \mathrm{e}--$ indicates that the relative percent difference was greater than the $\mathrm{QC}$ limit range.

- $\quad f$-- indicates that there was blank contamination.

Table B2-8. Tank 241-S-104 Analytical Results: Aluminum (ICP). (2 sheets)

\begin{tabular}{|c|c|c|c|c|c|}
\hline $\begin{array}{l}\text { Sample } \\
\text { Yromber }\end{array}$ & $\begin{array}{l}\text { Sumple } \\
\text { I roerion }\end{array}$ & $\begin{array}{l}\text { Sample } \\
\text { Prortion }\end{array}$ & Rerait & Dupllarite & Maro \\
\hline 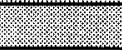 & \multicolumn{2}{|c|}{ 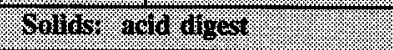 } & 1486 & 14968 & 1884 \\
\hline 2088 & \multirow[t]{2}{*}{ 43: 2} & Homogenized Test 1 & 20,400 & 18,800 & $19,600^{\mathrm{QC}: c}$ \\
\hline 2089 & & Homogenized Test 2 & 18,600 & 24,100 & $21,350^{\mathrm{oc}: \mathrm{c}}$ \\
\hline 2092 & \multirow[t]{2}{*}{$43: 4$} & Homogenized Test 1 & 35,700 & 72,400 & $54,050^{\mathrm{QC: \textrm {c }}}$ \\
\hline 2093 & & Homogenized Test 2 & 84,200 & 52,800 & $68,500^{\mathrm{QC}: c}$ \\
\hline 2096 & \multirow[t]{2}{*}{ 43: 6} & Homogenized Test 1 & 51,800 & 49,900 & $50,850^{\mathrm{CC}: c}$ \\
\hline 2097 & & Homogenized Test 2 & 49,300 & 55,900 & $52,600^{Q C: c}$ \\
\hline 2171 & \multirow[t]{2}{*}{ Core 42} & Solid composite & 42,300 & 30,000 & $36,150^{\mathrm{QC:c}}$ \\
\hline 2172 & & Solid composite & 42,900 & 58,200 & $50,550^{\mathrm{QC}: c}$ \\
\hline 2175 & \multirow[t]{2}{*}{ Core 43} & Solid composite & 21,400 & 22,200 & $21,800^{\mathrm{QC:c}}$ \\
\hline 2176 & & Solid composite & 29,400 & 26,800 & $28,100^{\mathrm{QC:c}}$ \\
\hline 2177 & \multirow[t]{2}{*}{ Core 44} & Solid composite & 63,100 & 61,500 & $62,300^{\mathrm{QC:c}}$ \\
\hline 2178 & & Solid composite & 34,900 & 33,800 & $34,350^{\mathrm{QC}: \mathrm{c}}$ \\
\hline
\end{tabular}


Table B2-8. Tank 241-S-104 Analytical Results: Aluminum (ICP). (2 sheets)

\begin{tabular}{|c|c|c|c|c|c|}
\hline $\begin{array}{l}\text { Suriplor } \\
\text { Niminer }\end{array}$ & 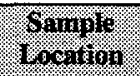 & $\begin{array}{l}\text { Sample } \\
\text { Rorition }\end{array}$ & $\mathrm{R}(2)$ & Duplicate & Mear \\
\hline & Solis: & Minion: & 1.965 & 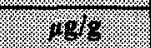 & $106 \%$ \\
\hline 2171 & \multirow[t]{2}{*}{ Core 42} & Solid composite & $1.160 \mathrm{E}+05$ & $1.110 \mathrm{E}+05$ & $1.135 \mathrm{E}+05^{\mathrm{QC}: \mathrm{c}}$ \\
\hline 2172 & & Solid composite & $1.190 \mathrm{E}+05$ & $1.130 \mathrm{E}+05$ & $1.160 \mathrm{E}+05^{\mathrm{QC}: c}$ \\
\hline 2175 & \multirow[t]{2}{*}{ Core 43} & Solid composite & $1.190 \mathrm{E}+05$ & $1.220 \mathrm{E}+05$ & $1.205 \mathrm{E}+05$ \\
\hline 2176 & & Solid composite & $1.220 \mathrm{E}+05$ & $1.140 \mathrm{E}+05$ & $1.180 \mathrm{E}+05$ \\
\hline 2177 & \multirow[t]{2}{*}{ Core 44} & Solid composite & $1.150 \mathrm{E}+05$ & $1.230 \mathrm{E}+05$ & $1.190 \mathrm{E}+05$ \\
\hline 2178 & & Solid composite & $1.170 \mathrm{E}+05$ & $1.130 \mathrm{E}+05$ & $1.150 \mathrm{E}+05$ \\
\hline . & \multicolumn{2}{|c|}{ Soldot Y Vater digest } & 1.98 & 1068 & 4.6 .968 \\
\hline 2171 & \multirow[t]{2}{*}{ Core 42} & Solid composite & 6,670 & 6,310 & 6,490 \\
\hline 2172 & & Solid composite & 6,540 & 5,930 & 6,235 \\
\hline 2175 & \multirow[t]{2}{*}{ Core 43} & Solid composite & 6,080 & 6,070 & $6,075^{\mathrm{QC:c}}$ \\
\hline 2176 & & Solid composite & 5,980 & 6,300 & $6,140^{\overline{\mathrm{eC}: c}}$ \\
\hline 2177 & \multirow[t]{2}{*}{ Core 44} & Solid composite & 1,190 & 1,890 & 1,540 \\
\hline 2178 & & Solid composite & 1,930 & 1,260 & 1,595 \\
\hline \multicolumn{3}{|c|}{ 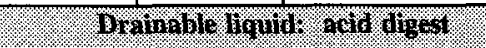 } & 1982 & 1895 & 1898 \\
\hline 2247 & 42: 1 & Drainable liquid & $9,687.5$ & & $9,687.5$ \\
\hline 2249 & 43: 1 & Drainable liquid & $8,593.75$ & & $8,593.75$ \\
\hline 2248 & $44: 1$ & Drainable liquid & $9,765.62$ & & $9,765.62$ \\
\hline (1) & \multicolumn{2}{|c|}{ Wuer divinion } & 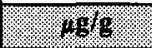 & 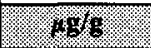 & 1.98 \\
\hline 2005 & $44: 6$ & Water dilution & 5,120 & 4,940 & 5,030 \\
\hline 2006 & $44: 6$ & Water dilution & 5,100 & 5,300 & 5,200 \\
\hline 2007 & $44: 6$ & Water dilution & 4,740 & 4,760 & 4,750 \\
\hline 2008 & $44: 6$ & Water dilution & 5,490 & 5,230 & 5,360 \\
\hline 2010 & $44: 6$ & Water dilution & 1,860 & 1,980 & 1,920 \\
\hline
\end{tabular}


Table B2-9. Tank 241-S-104 Analytical Results: Antimony (ICP). (2 sheets)

\begin{tabular}{|c|c|c|c|c|c|}
\hline Thompling & Somple & 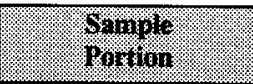 & in $(1)=$ & 8upterte & Hequin \\
\hline 率 & \multicolumn{2}{|c|}{ 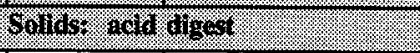 } & 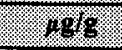 & 1884 & 198 \\
\hline 2088 & \multirow[t]{2}{*}{$43: 2$} & Homogenized Test 1 & $<14.5$ & 22 & $<18.25$ \\
\hline 2089 & & Homogenized Test 2 & $<14.8$ & $<14.5$ & $<14.65$ \\
\hline 2092 & \multirow[t]{2}{*}{$43: 4$} & Homogenized Test 1 & 35 & $<34.5$ & $<34.75$ \\
\hline 2093 & & Homogenized Test 2 & $<35$ & 41.3 & $<38.15$ \\
\hline 2096 & \multirow[t]{2}{*}{$43: 6$} & Homogenized Test 1 & $<36.3$ & $<34.5$ & $<35.4$ \\
\hline 2097 & & Homogenized Test 2 & $<53.1$ & 52.6 & $<52.85$ \\
\hline 2171 & \multirow[t]{2}{*}{ Core 42} & Solid composite & $<35.1$ & $<35.4$ & $<35.25$ \\
\hline 2172 & & Solid composite & $<36.2$ & $<35$ & $<35.6$ \\
\hline 2175 & \multirow[t]{2}{*}{ Core 43} & Solid composite & $<34.4$ & $\overline{34}$ & $<34.2$ \\
\hline 2176 & & Solid composite & $<34.9$ & $<35.1$ & $<35$ \\
\hline 2177 & \multirow[t]{2}{*}{ Core 44} & Solid composite & 35.8 & 38.1 & 36.95 \\
\hline 2178 & & Solid composite & $<34.5$ & 40.5 & $<37.5$ \\
\hline & \multicolumn{2}{|c|}{ 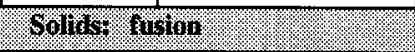 } & 15 & 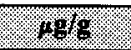 & . \\
\hline 2171 & \multirow[t]{2}{*}{ Core 42} & Solid composite & $<183$ & $<183$ & $<183$ \\
\hline 2172 & & Solid composite & $<180$ & $<182$ & $<181$ \\
\hline 2175 & \multirow[t]{2}{*}{ Core 43} & Solid composite & $<75.5$ & $<75.1$ & $<75.3$ \\
\hline 2176 & & Solid composite & $<74.5$ & $<74.2$ & $<74.35$ \\
\hline 2177 & \multirow[t]{2}{*}{ Core 44} & Solid composite & $<176$ & $<178$ & $<177$ \\
\hline 2178 & & Solid composite & $<176$ & $<177$ & $<176.5$ \\
\hline & \multicolumn{2}{|c|}{ 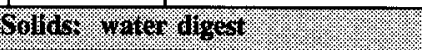 } & $1 \% \mathrm{~g}$ & 1096 & 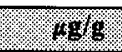 \\
\hline 2171 & \multirow[t]{2}{*}{ Core 42} & Solid composite & $<37.2$ & $<37$ & $<37.1$ \\
\hline 2172 & & Solid composite & $<37.2$ & $<37.3$ & $<37.25$ \\
\hline 2175 & \multirow[t]{2}{*}{ Core 43} & Solid composite & $<35.6$ & $<35.6$ & $<35.6$ \\
\hline 2176 & & Solid composite & $<36$ & $<36$ & $<36$ \\
\hline 2177 & \multirow[t]{2}{*}{ Core 44} & Solid composite & $<36.2$ & $<36.3$ & $<36.25$ \\
\hline 2178 & & Solid composite & $<36.2$ & $<36.3$ & $<36.25$ \\
\hline
\end{tabular}


Table B2-9. Tank 241-S-104 Analytical Results: Antimony (ICP). (2 sheets)

\begin{tabular}{|c|c|c|c|c|c|}
\hline $\begin{array}{l}\text { Oninilo } \\
\text { Wninger }\end{array}$ & 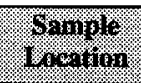 & Poriton & nesull & Buplioging & Mean \\
\hline \multicolumn{3}{|c|}{ 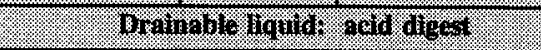 } & 18 & $153 \%$ & 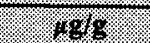 \\
\hline 2247 & 42: 1 & Drainable liquid & 6.07812 & & $6.08^{\mathrm{QC}: f}$ \\
\hline 2249 & 43: 1 & Drainable liquid & $<5.84375$ & & $<5.84$ \\
\hline 2248 & 44: 1 & Drainable liquid & $<8.04688$ & & $<8.05$ \\
\hline \multicolumn{3}{|c|}{ 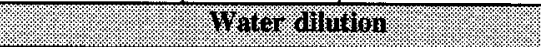 } & 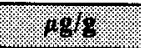 & 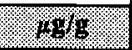 & $3 \%$ \\
\hline 2005 & $44: 6$ & Water dilution & $<29.6$ & $<36.6$ & $<33.1$ \\
\hline 2006 & & Water dilution & $<37$ & $<37.1$ & $<37.05$ \\
\hline 2007 & & Water dilution & $<36.9$ & $<36.7$ & $<36.8$ \\
\hline 2008 & & Water dilution & $<34.7$ & $<34.9$ & $<34.8$ \\
\hline 2010 & & Water dilution & $<14.9$ & $<15$ & $<14.95^{\mathrm{QC}: \mathrm{f}}$ \\
\hline
\end{tabular}

Table B2-10. Tank 241-S-104 Analytical Results: Arsenic (ICP). (2 sheets)

\begin{tabular}{|c|c|c|c|c|c|}
\hline $\begin{array}{l}\text { Shinjur } \\
\text { Minnor }\end{array}$ & onanor & 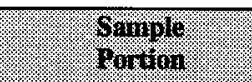 & aresulis & Puplisarse & Menin \\
\hline & \multicolumn{2}{|c|}{ Q1014 } & $10 \%$ & 4 & . \\
\hline 2088 & \multirow[t]{2}{*}{ 43: 2} & Homogenized Test 1 & $<3.73$ & $<3.73$ & $<3.73$ \\
\hline 2089 & & Homogenized Test 2 & $<3.79$ & $<3.71$ & $<3.75$ \\
\hline 2092 & \multirow[t]{2}{*}{$43: 4$} & Homogenized Test 1 & $<2.84$ & $<3$ & $<2.92$ \\
\hline 2093 & & Homogenized Test 2 & $<3.05$ & $<3.1$ & $<3.075$ \\
\hline 2096 & \multirow[t]{2}{*}{$43: 6$} & Homogenized Test 1 & $<2.97$ & $<2.82$ & $<2.90$ \\
\hline 2097 & & Homogenized Test 2 & $<4.62$ & 6.32 & $<5.47$ \\
\hline 2171 & \multirow[t]{2}{*}{ Core 42} & Solid composite & $<2.87$ & $<2.9$ & $<2.88$ \\
\hline 2172 & & Solid composite & $<2.97$ & $<2.87$ & $<2.92$ \\
\hline 2175 & \multirow[t]{2}{*}{ Core 43} & Solid composite & $<2.99$ & $<2.96$ & $<2.98$ \\
\hline 2176 & & Solid composite & $<3.04$ & $<3.06$ & $<3.05$ \\
\hline 2177 & \multirow[t]{2}{*}{ Core 44} & Solid composite & $<3.05$ & $<2.98$ & $<3.02$ \\
\hline 2178 & & Solid composite & 5.08 & 5.83 & 5.46 \\
\hline
\end{tabular}


Table B2-10. Tank 241-S-104 Analytical Results: Arsenic (ICP). (2 sheets)

\begin{tabular}{|c|c|c|c|c|c|}
\hline Oaniol & \%ormove & $\begin{array}{l}\mid \text { Sample } \\
\text { Vortion }\end{array}$ & Pissuli: & Bisiligite & 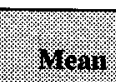 \\
\hline & tortide. & rosion & $\sqrt[196]{196}$ & $.169 \mathrm{~g}$ & 1486 \\
\hline 2171 & \multirow[t]{2}{*}{ Core 42} & Solid composite & $<15$ & $<15$ & $<15$ \\
\hline 2172 & & Solid composite & $<14.8$ & $<14.9$ & $<14.85$ \\
\hline 2175 & \multirow[t]{2}{*}{ Core 43} & Solid composite & $<19.4$ & $<19.3$ & $<19.35$ \\
\hline 2176 & & Solid composite & $<19.1$ & $<19$ & $<19.05$ \\
\hline 2177 & \multirow[t]{2}{*}{ Core 44} & Solid composite & $<15.3$ & $<15.5$ & $<15.4$ \\
\hline 2178 & & Solid composite & $<15.3$ & $<15.4$ & $<15.35$ \\
\hline & \multicolumn{2}{|c|}{ Sollows: Inter diger: } & 1968 & 1.968 & $.49 / 6$ \\
\hline 2171 & \multirow[t]{2}{*}{ Core 42} & Solid composite & $<3.05$ & $<3.03$ & $<3.04$ \\
\hline 2172 & & Solid composite & $<3.05$ & $<3.06$ & $<3.06$ \\
\hline 2175 & \multirow[t]{2}{*}{ Core 43} & Solid composite & $<3.1$ & $<3.1$ & $<3.1$ \\
\hline 2176 & & Solid composite & $<3.14$ & $<3.13$ & $<3.14$ \\
\hline 2177 & \multirow[t]{2}{*}{ Core 44} & Solid composite & $<3.16$ & $<3.16$ & $<3.16$ \\
\hline 2178 & & Solid composite & $<3.16$ & $<3.16$ & $<3.16$ \\
\hline 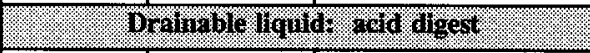 & \multicolumn{2}{|c|}{ 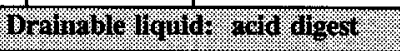 } & 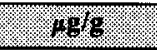 & 1996 & (1989.8. \\
\hline 2247 & 42: 1 & Drainable liquid & $<0.761719$ & & $<0.76$ \\
\hline 2249 & 43: 1 & Drainable liquid & $<0.304688$ & & $<0.30$ \\
\hline 2248 & 44: 1 & Drainable liquid & $<0.304688$ & & $<0.30$ \\
\hline & \multicolumn{2}{|c|}{ Water dilution } & $4 \mathrm{~g} / \mathrm{g}$ & 10.6\% & 1928. \\
\hline 2005 & \multirow[t]{6}{*}{ 44: 6} & Water dilution & 8.48 & 8.44 & 8.46 \\
\hline 2006 & & Water dilution & 14.5 & 14 & $14.25^{\mathrm{QC:f}}$ \\
\hline 2007 & & Water dilution & $<3.02$ & $<3.01$ & $<3.02$ \\
\hline 2008 & & Water dilution & $<2.84$ & $<2.86$ & $<2.85$ \\
\hline \multirow[t]{2}{*}{2010} & & Water dilution & $<3.81$ & $<3.85$ & $<3.83$ \\
\hline & & Water dilution & 3.74 & 4.59 & 4.17 \\
\hline
\end{tabular}


Table B2-11. Tank 241-S-104 Analytical Results: Arsenic (Atomic Absorption).

\begin{tabular}{|c|c|c|c|c|c|}
\hline 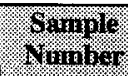 & 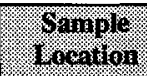 & (1) & tesili & Borlionto & yeshis \\
\hline \% & Yols & & \% & 14.19 & 40 \\
\hline 2171 & \multirow[t]{2}{*}{ Core 42} & Solid composite & $<0.25$ & $<0.25$ & $<0.25$ \\
\hline 2172 & & Solid composite & $<0.25$ & $<0.25$ & $<0.25$ \\
\hline 2175 & \multirow[t]{2}{*}{ Core 43} & Solid composite & $<0.25$ & $<0.25$ & $<0.25$ \\
\hline 2176 & & Solid composite & $<0.25$ & $<0.25$ & $<0.25$ \\
\hline 2177 & \multirow[t]{2}{*}{ Core 44} & Solid composite & $<0.25$ & $<0.25$ & $<0.25$ \\
\hline 2178 & & Solid composite & $<0.25$ & $<0.25$ & $<0.25$ \\
\hline
\end{tabular}

Table B2-12. Tank 241-S-104 Analytical Results: Barium (ICP). (2 sheets)

\begin{tabular}{|c|c|c|c|c|c|}
\hline Womplo & 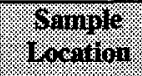 & (6) & 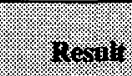 & 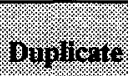 & 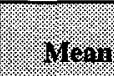 \\
\hline & \multicolumn{2}{|c|}{ oflins, } & $4 \%$ & 40 & $1 \%$ \\
\hline 2088 & \multirow[t]{2}{*}{$43: 2$} & Homogenized Test 1 & 16.1 & 17 & 16.55 \\
\hline 2089 & & Homogenized Test 2 & 16.9 & 17.3 & 17.1 \\
\hline 2092 & \multirow[t]{2}{*}{$43: 4$} & Homogenized Test 1 & 34.7 & 36.6 & 35.65 \\
\hline 2093 & & Homogenized Test 2 & 38.2 & 33.8 & 36 \\
\hline 2096 & \multirow[t]{2}{*}{$43: 6$} & Homogenized Test 1 & 18.3 & 22.1 & 20.2 \\
\hline 2097 & & Homogenized Test 2 & 21.9 & 20.6 & 21.25 \\
\hline 2171 & \multirow[t]{2}{*}{ Core 42} & Solid composite & 20.8 & 20 & 20.4 \\
\hline 2172 & & Solid composite & 22.1 & 22.9 & 22.5 \\
\hline 2175 & \multirow[t]{2}{*}{ Core 43} & Solid composite & 20.5 & 19.2 & 19.85 \\
\hline 2176 & & Solid composite & 20.4 & 19.4 & 19.9 \\
\hline 2177 & \multirow[t]{2}{*}{ Core 44} & Solid composite & 25.9 & 25.8 & 25.85 \\
\hline 2178 & & Solid composite & 21.4 & 20.3 & 20.85 \\
\hline & \multicolumn{2}{|c|}{ 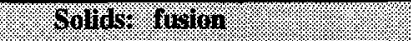 } & 9.98. & 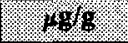 & 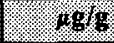 \\
\hline 2171 & \multirow[t]{2}{*}{ Core 42} & Solid composite & 29.3 & 26.9 & 28.1 \\
\hline 2172 & & Solid composite & 31.5 & 30.6 & 31.05 \\
\hline
\end{tabular}


Table B2-12. Tank 241-S-104 Analytical Results: Barium (ICP). (2 sheets)

\begin{tabular}{|c|c|c|c|c|c|}
\hline mover & 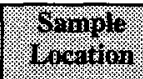 & Ganplo & $\mathrm{R}_{2}=411$ & Bulligate & Mrin \\
\hline & \multicolumn{2}{|c|}{$6010 \%$ r f } & 189 & (10) & $4 \% 8$ \\
\hline 2175 & \multirow[t]{2}{*}{ Core 43} & Solid composite & 33.4 & 34.3 & 33.85 \\
\hline 2176 & & Solid composite & 35.1 & 34.1 & 34.6 \\
\hline 2177 & \multirow[t]{2}{*}{ Core 44} & Solid composite & 33.6 & 38.8 & 36.2 \\
\hline 2178 & & Solid composite & 36.7 & 33.3 & $\overline{35}$ \\
\hline & \multicolumn{2}{|c|}{ 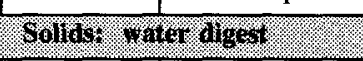 } & 148 & 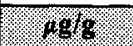 & 148 \\
\hline 2171 & \multirow[t]{2}{*}{ Core 42} & Solid composite & $<0.305$ & 1.61 & $<0.96$ \\
\hline 2172 & & Solid composite & $<0.305$ & $<0.306$ & $<0.31$ \\
\hline 2175 & \multirow[t]{2}{*}{ Core 43} & Solid composite & 0.314 & $<0.3$ & $<0.31$ \\
\hline 2176 & & Solid composite & $<0.304$ & 0.319 & $<0.31$ \\
\hline 2177 & \multirow[t]{2}{*}{ Core 44} & Solid composite & $<0.305$ & $<0.306$ & $<\overline{0.31}$ \\
\hline 2178 & & Solid composite & 0.329 & $<0.306$ & $<\overline{0.32}$ \\
\hline \multicolumn{3}{|c|}{ 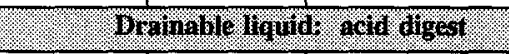 } & 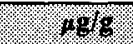 & 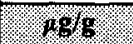 & 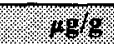 \\
\hline 2247 & 42: 1 & Drainable liquid & $<0.078$ & & $<0.078$ \\
\hline 2249 & 43: 1 & Drainable liquid & $3.12 \mathrm{E}-04$ & & $3.12 \mathrm{E}-04$ \\
\hline 2248 & $44: 1$ & Drainable liquid & 0.031 & & 0.031 \\
\hline & \multicolumn{2}{|c|}{ 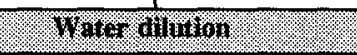 } & 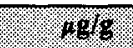 & 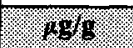 & Why \\
\hline 2005 & \multirow[t]{5}{*}{$44: 6$} & Water dilution & $<0.24$ & $<0.3$ & $<0.27$ \\
\hline 2006 & & Water dilution & 0.30 & $<0.304$ & $<0 . \overline{30}$ \\
\hline 2007 & & Water dilution & 0.41 & $<0.301$ & $<0.36$ \\
\hline 2008 & & Water dilution & $<0.28$ & $<0.286$ & $<0.28$ \\
\hline 2010 & & Water dilution & $<0.39$ & $<0.395$ & $<0.39$ \\
\hline
\end{tabular}


Table B2-13. Tank 241-S-104 Analytical Results: Beryllium (ICP). (2 sheets)

\begin{tabular}{|c|c|c|c|c|c|}
\hline Whinger & $4.2 \% 10$ & . 6.9019 & Prosuli & byillicita & 18. \\
\hline \multicolumn{3}{|c|}{ ow } & \%to & $48 \%$ & $14 \%$ \\
\hline 2088 & \multirow[t]{2}{*}{ 43: 2} & Homogenized Test 1 & $<0.29$ & $<0.29$ & $<0.29$ \\
\hline 2089 & & Homogenized Test 2 & 0.44 & $<0.28$ & $<0.36$ \\
\hline 2092 & \multirow[t]{2}{*}{$43: 4$} & Homogenized Test 1 & $<0.27$ & $<0.29$ & $<0.28$ \\
\hline 2093 & & Homogenized Test 2 & $<0.30$ & $<0.3$ & $<0.30$ \\
\hline 2096 & \multirow[t]{2}{*}{$43: 6$} & Homogenized Test 1 & $<0.30$ & $<0.28$ & $<0.29$ \\
\hline 2097 & & Homogenized Test 2 & $<0.45$ & $<0.39$ & $<0.42$ \\
\hline 2171 & \multirow[t]{2}{*}{ Core 42} & Solid composite & $<0.29$ & $<0.29$ & $<0.29$ \\
\hline 2172 & & Solid composite & $<0.230$ & $<0.29$ & $<0.29$ \\
\hline 2175 & \multirow[t]{2}{*}{ Core 43} & Solid composite & $<0.29$ & $<0.29$ & $<0.29$ \\
\hline 2176 & & Solid composite & $<0.29$ & $<0.30$ & $<0.30$ \\
\hline 2177 & \multirow[t]{2}{*}{ Core 44} & Solid composite & $<0.30$ & $<0.29$ & $<0.29$ \\
\hline 2178 & & Solid composite & $<0.29$ & $<0.29$ & $<0 . \overline{29}$ \\
\hline & \multicolumn{2}{|c|}{ 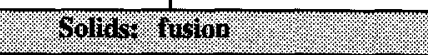 } & 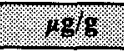 & 1010. & $16 \mathrm{~d}$ \\
\hline 2171 & \multirow[t]{2}{*}{ Core 42} & Solid composite & $<1.5$ & $<1.5$ & $<1.5$ \\
\hline 2172 & & Solid composite & $<1.48$ & $<1.49$ & $<1.485$ \\
\hline 2175 & \multirow[t]{2}{*}{ Core 43} & Solid composite & $<1.49$ & $<1.48$ & $<1.485$ \\
\hline 2176 & & Solid composite & $<1.47$ & $<1.46$ & $<1.465$ \\
\hline 2177 & \multirow[t]{2}{*}{ Core 44} & Solid composite & $<1.48$ & $<1.5$ & $<1.49$ \\
\hline 2178 & & Solid composite & $<1.49$ & $<1.49$ & $<1.49$ \\
\hline & \multicolumn{2}{|c|}{ oglow } & 48 & 189 & 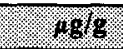 \\
\hline 2171 & \multirow[t]{2}{*}{ Core 42} & Solid composite & $<0.305$ & $<0.303$ & $<0.304$ \\
\hline 2172 & & Solid composite & $<0.305$ & $<0.306$ & $<0.3055$ \\
\hline 2175 & \multirow[t]{2}{*}{ Core 43} & Solid composite & $<0.3$ & $<0.3$ & $<0.3$ \\
\hline 2176 & & Solid composite & $<0.304$ & $<0.303$ & $<0.3035$ \\
\hline 2177 & \multirow[t]{2}{*}{ Core 44} & Solid composite & $<\overline{0.305}$ & $<0.306$ & $<0.3055$ \\
\hline 2178 & & Solid composite & $<0.305$ & $<0.306$ & $<0.3055$ \\
\hline
\end{tabular}


Table B2-13. Tank 241-S-104 Analytical Results: Beryllium (ICP). (2 sheets)

\begin{tabular}{|c|c|c|c|c|c|}
\hline 6rition & 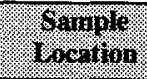 & - romplo & kevily & Bupllogte & Mlern \\
\hline \multicolumn{3}{|c|}{ 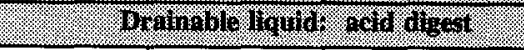 } & 180 & 140. & $4 \%$ \\
\hline 2247 & 42: 1 & Drainable liquid & 0.17 & & 0.17 \\
\hline 2249 & 43: 1 & Drainable liquid & 0.13 & & 0.13 \\
\hline 2248 & 44: 1 & Drainable liquid & 0.14 & & 0.14 \\
\hline \multicolumn{3}{|c|}{ Worominon } & 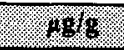 & $18 \%$ & 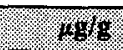 \\
\hline 2005 & \multirow[t]{6}{*}{$44: 6$} & Water dilution & $<0.24$ & $<0.3$ & $<0.27$ \\
\hline 2006 & & Water dilution & $<0.30$ & $<0.30$ & $<0.30$ \\
\hline 2007 & & Water dilution & $<0.30$ & $<0.30$ & $<0.30$ \\
\hline 2008 & & Water dilution & $<0.28$ & $<0.29$ & $<0.29$ \\
\hline \multirow[t]{2}{*}{2010} & & Water dilution & $<0.29$ & $<0.30$ & $<0.29$ \\
\hline & & Water dilution & $<0.30$ & $<0.31$ & $\begin{array}{c}<0.31 \\
0.3055^{\text {QC:f }}\end{array}$ \\
\hline
\end{tabular}

Table B2-14. Tank 241-S-104 Analytical Results: Bismuth (ICP).

( 2 sheets)

\begin{tabular}{|c|c|c|c|c|c|}
\hline Yarmore & orangen & f. & Resuln. & Ounlisate & Mran \\
\hline & Woulu & artory & $\% \mathrm{~g}$ & 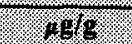 & 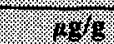 \\
\hline 2088 & \multirow[t]{2}{*}{ 43:2 } & Homogenized Test 1 & $<8.8$ & $<8.8$ & $<8.8$ \\
\hline 2089 & & Homogenized Test 2 & $<8.94$ & $<8.75$ & $<8.845$ \\
\hline 2092 & \multirow[t]{2}{*}{$43: 4$} & Homogenized Test 1 & $<7.79$ & $<8.23$ & $<8.01$ \\
\hline 2093 & & Homogenized Test 2 & $<8.35$ & $<8.5$ & $<8.425$ \\
\hline 2096 & \multirow[t]{2}{*}{$43: 6$} & Homogenized Test 1 & $<5.75$ & $<5.46$ & $<5.605$ \\
\hline 2097 & & Homogenized Test 2 & $<12.7$ & $<11$ & $<11.85$ \\
\hline 2171 & \multirow[t]{2}{*}{ Core 42} & Solid composite & $<5.56$ & $<5.61$ & $<5.585$ \\
\hline 2172 & & Solid composite & $<5.74$ & $<5.55$ & $<5.645$ \\
\hline 2175 & \multirow[t]{2}{*}{ Core 43} & Solid composite & $<8.2$ & $<8.1$ & $<8.15$ \\
\hline 2176 & & Solid composite & $<8.33$ & $<8.38$ & $<8.355$ \\
\hline 2177 & \multirow[t]{2}{*}{ Core 44} & Solid composite & $<8.37$ & $<8.17$ & $<8.27$ \\
\hline 2178 & & Solid composite & $<8.23$ & $<8.09$ & $<8.16$ \\
\hline
\end{tabular}


Table B2-14. Tank 241-S-104 Analytical Results: Bismuth (ICP).

( 2 sheets)

\begin{tabular}{|c|c|c|c|c|c|}
\hline ofaninge & (6) & (1). & ocsinil & 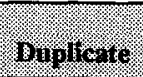 & 16an \\
\hline \multicolumn{3}{|c|}{ \%1\% } & (1) & $\%$ & . 101 \\
\hline 2171 & \multirow[t]{2}{*}{ Core 42} & Solid composite & $<29$ & $<29$ & $<29$ \\
\hline 2172 & & Solid composite & $<28.6$ & $<28.8$ & $<28.7$ \\
\hline 2175 & \multirow[t]{2}{*}{ Core 43} & Solid composite & $<45.7$ & $<45.5$ & $<45.6$ \\
\hline 2176 & & Solid composite & $<45.1$ & $<44.9$ & $<45$ \\
\hline 2177 & \multirow[t]{2}{*}{ Core 44} & Solid composite & $<41.9$ & $<42.5$ & $<42.2$ \\
\hline 2178 & & Solid composite & $<42.1$ & $<42.2$ & $<42.15$ \\
\hline & \multicolumn{2}{|c|}{ 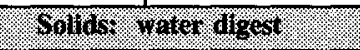 } & 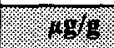 & 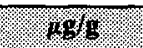 & 1048 \\
\hline 2171 & \multirow[t]{2}{*}{ Core 42} & Solid composite & $<5.89$ & $<5.86$ & $<5.875$ \\
\hline 2172 & & Solid composite & $<5.89$ & $<5.92$ & $<5.905$ \\
\hline 2175 & \multirow[t]{2}{*}{ Core 43} & Solid composite & $<8.5$ & $<8.5$ & $<8.5$ \\
\hline 2176 & & Solid composite & $<8.6$ & $<8.58$ & $<8.59$ \\
\hline 2177 & \multirow[t]{2}{*}{ Core 44} & Solid composite & $<8.65$ & $<8.67$ & $<8.66$ \\
\hline 2178 & & Solid composite & $<8.65$ & $<8.66$ & $<8.655$ \\
\hline \multicolumn{3}{|c|}{ 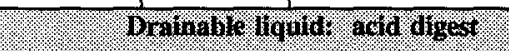 } & $1 \%$ g: & 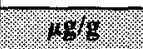 & $49 \%$ \\
\hline 2249 & 43:1 & Drainable liquid & 0.72 & & $0.72^{\mathrm{QC}: \mathrm{f}}$ \\
\hline 2248 & $44: 1$ & Drainable liquid & 0.72 & & $0.72^{\mathrm{QC}: \mathrm{f}}$ \\
\hline & \multicolumn{2}{|c|}{ What inition: } & (x) & 40 & 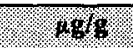 \\
\hline 2005 & \multirow[t]{5}{*}{$44: 6$} & Water dilution & $<4.7$ & $<5.8$ & $<5.25$ \\
\hline 2006 & & Water dilution & $<5.87$ & $<5.88$ & $<5.88$ \\
\hline 2007 & & Water dilution & $<5.85$ & $<5.81$ & $<5.83$ \\
\hline 2008 & & Water dilution & $<5.5$ & $<5.53$ & $<5.52$ \\
\hline 2010 & & Water dilution & $<8.99$ & $<9.09$ & $<9.04^{\mathrm{QC}: \mathrm{f}}$ \\
\hline
\end{tabular}


HNF-SD-WM-ER-370 Rev. 1

Table B2-15. Tank 241-S-104 Analytical Results: Boron (ICP). (2 sheets)

\begin{tabular}{|c|c|c|c|c|c|}
\hline . Oanple & Gormor & . & ingsing & 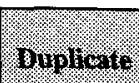 & Wron \\
\hline \multicolumn{3}{|c|}{ 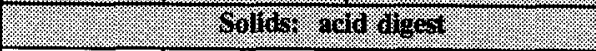 } & $16 \%$ & 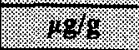 & 49 \\
\hline 2088 & \multirow[t]{2}{*}{$43: 2$} & Homogenized Test 1 & 14.6 & 14.8 & 14.7 \\
\hline 2089 & & Homogenized Test 2 & 12.1 & $\overline{14.6}$ & 13.35 \\
\hline 2092 & \multirow[t]{2}{*}{$43: 4$} & Homogenized Test 1 & 26 & 22.4 & 24.2 \\
\hline 2093 & & Homogenized Test 2 & 17.5 & 7.39 & 12.44 \\
\hline 2096 & \multirow[t]{2}{*}{$43: 6$} & Homogenized Test 1 & 9.71 & 10.6 & 10.15 \\
\hline 2097 & & Homogenized Test 2 & 16.4 & 18.5 & 17.45 \\
\hline 2171 & \multirow[t]{2}{*}{ Core 42} & Solid composite & 10.5 & 13.5 & 12 \\
\hline 2172 & & Solid composite & 8.82 & 10.5 & 9.66 \\
\hline 2175 & \multirow[t]{2}{*}{ Core 43} & Solid composite & 9.13 & 9.48 & $9 . \overline{305}$ \\
\hline 2176 & & Solid composite & 15.5 & 9.95 & 12.72 \\
\hline 2177 & \multirow[t]{2}{*}{ Core $\overline{44}$} & Solid composite & 21.6 & 17.5 & 19.55 \\
\hline 2178 & & Solid composite & 21.2 & 25.3 & 23.25 \\
\hline
\end{tabular}


Table B2-15. Tank 241-S-104 Analytical Results: Boron (ICP). (2 sheets)

\begin{tabular}{|c|c|c|c|c|c|}
\hline Ginol & 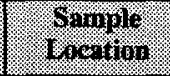 & \%orpil & nesilin & 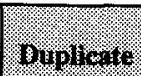 & 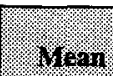 \\
\hline 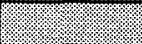 & \%oly & $1916 \%$ & 48 & . & 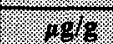 \\
\hline 2171 & \multirow[t]{2}{*}{ Core 42} & Solid composite & $<5$ & $<5$ & $<5$ \\
\hline 2172 & & Solid composite & $<4.93$ & $<4.96$ & $<4.945$ \\
\hline 2175 & \multirow[t]{2}{*}{ Core 43} & Solid composite & 40.5 & 29.9 & 35.2 \\
\hline 2176 & & Solid composite & 165 & 20 & 92.5 \\
\hline 2177 & \multirow[t]{2}{*}{ Core 44} & Solid composite & $<9.37$ & 10.6 & $<9.985$ \\
\hline 2178 & & Solid composite & 10.2 & 14.1 & 12.15 \\
\hline & \multicolumn{2}{|c|}{ 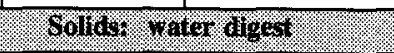 } & 169 & 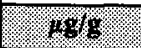 & 1018 \\
\hline 2171 & \multirow[t]{2}{*}{ Core 42} & Solid composite & 10.9 & 10.8 & 10.85 \\
\hline 2172 & & Solid composite & 9.2 & 9.33 & 9.265 \\
\hline 2175 & \multirow[t]{2}{*}{ Core 43} & Solid composite & 10 & 11 & 10.5 \\
\hline 2176 & & Solid composite & 10.9 & 10.7 & 10.8 \\
\hline 2177 & \multirow[t]{2}{*}{ Core 44} & Solid composite & 5.62 & 7.92 & 6.77 \\
\hline 2178 & & Solid composite & 7.35 & 5.27 & 6.31 \\
\hline \multicolumn{3}{|c|}{ 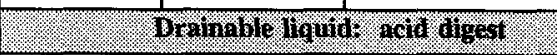 } & 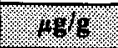 & 1690 & Ho \\
\hline 2247 & 42: 1 & Drainable liquid & 6.390 & & 6.39 \\
\hline 2249 & 43: 1 & Drainable liquid & $<4.023$ & & $<4.02$ \\
\hline 2248 & 44: 1 & Drainable liquid & $<4.91$ & & $<4.91$ \\
\hline \multicolumn{3}{|c|}{ Hor } & 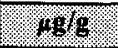 & 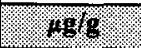 & 684 \\
\hline 2005 & \multirow[t]{5}{*}{$44: 6$} & Water dilution & 10.4 & 10.3 & $10.35^{\mathrm{QC}: \mathrm{f}}$ \\
\hline 2006 & & \begin{tabular}{|l} 
Water dilution \\
\end{tabular} & 12.9 & 13.2 & $13.05^{\mathrm{QC:f}}$ \\
\hline 2007 & & Water dilution & 26 & 26.4 & $26.2^{\mathrm{QC}: \mathrm{f}}$ \\
\hline 2008 & & Water dilution & 14.3 & 12.1 & $13.2^{\mathrm{QC:f}}$ \\
\hline 2010 & & Water dilution & 3.43 & 3.08 & 3.25 \\
\hline
\end{tabular}


Table B2-16. Tank 241-S-104 Analytical Results: Cadmium (ICP). (2 sheets)

\begin{tabular}{|c|c|c|c|c|c|}
\hline 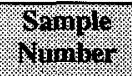 & 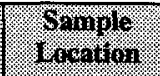 & 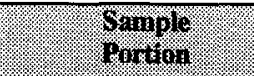 & To8411: & $(8)+1)=$ & Mean \\
\hline & \multicolumn{2}{|c|}{ oflor } & $18 \%$ & $4 \%$ & $1 \%$ \\
\hline 2088 & \multirow[t]{2}{*}{$43: 2$} & Homogenized Test 1 & $<0.67$ & $<0.67$ & $<0.67$ \\
\hline 2089 & & Homogenized Test 2 & 0.826 & 2.41 & 1.618 \\
\hline 2092 & \multirow[t]{2}{*}{$43: 4$} & Homogenized Test 1 & $<0.642$ & $<0.678$ & $<0.66$ \\
\hline 2093 & & Homogenized Test 2 & 0.745 & $<0.7$ & $<0.7225$ \\
\hline 2096 & \multirow[t]{2}{*}{$43: 6$} & Homogenized Test 1 & $<0.694$ & 0.888 & $<0.791$ \\
\hline 2097 & & Homogenized Test 2 & 1.25 & 1.26 & 1.255 \\
\hline $21 \overline{71}$ & \multirow[t]{2}{*}{ Core 42} & Solid composite & $<0.67$ & $<0.677$ & $<0.6735$ \\
\hline 2172 & & Solid composite & 0.735 & $<0.67$ & $<0.7025$ \\
\hline 2175 & \multirow[t]{2}{*}{ Core 43} & Solid composite & $<0.676$ & $<0.667$ & $<0.6715$ \\
\hline 2176 & & Solid composite & $<0.686$ & $<0.69$ & $<0.688$ \\
\hline 2177 & \multirow[t]{2}{*}{ Core 44} & Solid composite & 0.754 & 0.917 & 0.8355 \\
\hline 2178 & & Solid composite & $0 . \overline{687}$ & 0.937 & 0.812 \\
\hline & \multicolumn{2}{|c|}{ 6.017\%, fuston } & 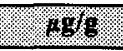 & . 19 & 1.418 \\
\hline 2171 & \multirow[t]{2}{*}{ Core 42} & Solid composite & $<3.5$ & $<3.5$ & $<3.5$ \\
\hline 2172 & & Solid composite & $<3.45$ & $<3.47$ & $<3.46$ \\
\hline 2175 & \multirow[t]{2}{*}{ Core 43} & Solid composite & 3.93 & 3.57 & 3.75 \\
\hline 2176 & & Solid composite & $<3.43$ & 3.58 & $<3.505$ \\
\hline 2177 & \multirow[t]{2}{*}{ Core 44} & Solid composite & $<3.45$ & $<3.5$ & $<3.475$ \\
\hline 2178 & & Solid composite & $<3.47$ & $<3.47$ & $<3.47$ \\
\hline 媇 & \multicolumn{2}{|c|}{ Soliter, $4 \%$ \% } & $18 \%$ & . $/ 89 \mathrm{~g}$ & 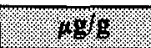 \\
\hline 2171 & \multirow[t]{2}{*}{ Core 42} & Solid composite & $<0.711$ & 0.9 & $<0.8055$ \\
\hline 2172 & & Solid composite & $<0.711$ & $<0.714$ & $<0.7125$ \\
\hline 2175 & \multirow[t]{2}{*}{ Core 43} & Solid composite & $<0.7$ & $<0.7$ & $<0.7$ \\
\hline 2176 & & Solid composite & $<0.708$ & $<0.707$ & $<0.7075$ \\
\hline 2177 & \multirow[t]{2}{*}{ Core 44} & Solid composite & $<0.713$ & $<0.714$ & $<0.7135$ \\
\hline 2178 & & Solid composite & $<0.713$ & $<0.713$ & $<0.713$ \\
\hline & \multicolumn{2}{|c|}{ 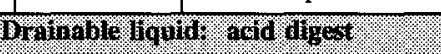 } & $.79 \mathrm{~g}$ & $1+x_{3}$ & 1.648 \\
\hline 2247 & 42: 1 & Drainable liquid & $<0.14$ & & $<0.14$ \\
\hline 2249 & 43: 1 & Drainable liquid & $<0.060$ & & $<0.060^{\mathrm{QC}: \mathrm{f}}$ \\
\hline 2248 & 44: 1 & Drainable liquid & $<0.070$ & & $<0.070^{\mathrm{QC}: \mathrm{f}}$ \\
\hline
\end{tabular}


Table B2-16. Tank 241-S-104 Analytical Results: Cadmium (ICP). (2 sheets)

\begin{tabular}{|c|c|c|c|c|c|}
\hline $\begin{array}{l}\text { Samples } \\
\text { Noniber }\end{array}$ & $\begin{array}{l}\text { Sample. } \\
\text { Eoca don }\end{array}$ & Simple & $63-319$ & Ouplicure & Mrean \\
\hline & \multicolumn{2}{|c|}{ 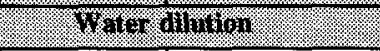 } & 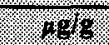 & (4) & 2408 \\
\hline 2005 & \multirow[t]{5}{*}{$44: 6$} & Water dilution & $<0.57$ & $<0.7$ & $<0.63$ \\
\hline 2006 & & Water dilution & $<0.71$ & $<0.71$ & $<0.71$ \\
\hline 2007 & & Water dilution & $<0.71$ & $<0 . \overline{70}$ & $<0.70$ \\
\hline 2008 & & Water dilution & $<0.66$ & $<0.67$ & $<0.67$ \\
\hline 2010 & & Water dilution & $<0.68$ & $<0.69$ & $<0.69$ \\
\hline
\end{tabular}

Table B2-17. Tank 241-S-104 Analytical Results: Calcium (ICP). (2 sheets)

\begin{tabular}{|c|c|c|c|c|c|}
\hline $\begin{array}{l}\text { Srmpolo } \\
\text { Number }\end{array}$ & STringle & \begin{tabular}{|l|l} 
Single \\
jortion
\end{tabular} & Resin: & Byilicite & nerin \\
\hline & \multicolumn{2}{|c|}{ 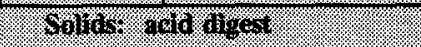 } & $48 \%$ & .898 & 486 \\
\hline 2088 & \multirow[t]{2}{*}{ 43: 2} & Homogenized Test 1 & 241 & 272 & 256.5 \\
\hline 2089 & & Homogenized Test 2 & 206 & 265 & 235.5 \\
\hline 2092 & \multirow[t]{2}{*}{$43: 4$} & Homogenized Test 1 & 222 & 221 & 221.5 \\
\hline 2093 & & Homogenized Test 2 & 225 & 215 & 220 \\
\hline 2096 & \multirow[t]{2}{*}{$43: 6$} & Homogenized Test 1 & 339 & 271 & $305^{\mathrm{QC:b}}$ \\
\hline 2097 & & Homogenized Test 2 & 331 & 314 & 322.5 \\
\hline 2171 & \multirow[t]{2}{*}{ Core 42} & Solid composite & 196 & 178 & 187 \\
\hline 2172 & & Solid composite & 213 & 202 & 207.5 \\
\hline 2175 & \multirow[t]{2}{*}{ Core 43} & Solid composite & 327 & 330 & $328.5^{\mathrm{QC}: \mathrm{b}}$ \\
\hline 2176 & & Solid composite & 269 & 203 & $236^{\mathrm{QC}: \mathrm{b}}$ \\
\hline 2177 & \multirow[t]{2}{*}{ Core 44} & Solid composite & 277 & 265 & 271 \\
\hline 2178 & & Solid composite & 264 & 236 & 250 \\
\hline
\end{tabular}


HNF-SD-WM-ER-370 Rev. 1

Table B2-17. Tank 241-S-104 Analytical Results: Calcium (ICP). (2 sheets)

\begin{tabular}{|c|c|c|c|c|c|}
\hline (1) & 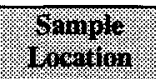 & : Ghimply & resuif & Bipliterio & Wear \\
\hline \multicolumn{3}{|c|}{ 6016\% } & 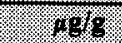 & 48 & 48 \\
\hline 2171 & \multirow[t]{2}{*}{ Core 42} & Solid composite & 972 & 423 & 697.5 \\
\hline 2172 & & Solid composite & 555 & 530 & 542.5 \\
\hline 2175 & \multirow[t]{2}{*}{ Core 43} & Solid composite & 833 & 696 & 764.5 \\
\hline 2176 & & Solid composite & 1,910 & 888 & 1,399 \\
\hline 2177 & \multirow[t]{2}{*}{ Core 44} & Solid composite & 4,050 & 3,450 & 3,750 \\
\hline 2178 & & Solid composite & 31,600 & 4,820 & 18,210 \\
\hline & \multicolumn{2}{|c|}{ 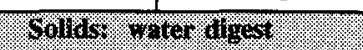 } & 489 & 18\% & $104 \%$ \\
\hline 2171 & \multirow{2}{*}{ Core 42} & Solid composite & 121 & 747 & 434 \\
\hline 2172 & & Solid composite & 67.2 & 148 & 107.6 \\
\hline 2175 & \multirow[t]{2}{*}{ Core 43} & Solid composite & 102 & 128 & 115 \\
\hline 2176 & & Solid composite & 108 & 90.9 & 99.45 \\
\hline 2177 & \multirow[t]{2}{*}{ Core 44} & Solid composite & 115 & 92.3 & 103.65 \\
\hline 2178 & & Solid composite & 78.9 & 67.8 & 73.35 \\
\hline 2247 & 42: 1 & Drainable liquid & 3.03 & & $3.03^{\mathrm{QC:f}}$ \\
\hline 2249 & 43: 1 & Drainable liquid & 0.039 & & 0.039 \\
\hline 2248 & 44: 1 & Drainable liquid & 0.039 & & 0.039 \\
\hline & \multicolumn{2}{|c|}{ Witer filfiro } & 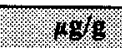 & 408 & 898 \\
\hline 2005 & \multirow[t]{6}{*}{$44: 6$} & Water dilution & 71.1 & 75.4 & $73.25^{\text {QC:f }}$ \\
\hline 2006 & & Water dilution & 521 & 73.9 & $297.45^{\text {QC:f }}$ \\
\hline 2007 & & Water dilution & 116 & 113 & $114.5^{\text {QC:f }}$ \\
\hline 2008 & & Water dilution & 72.6 & 90.5 & $81.55^{\text {QC:f }}$ \\
\hline \multirow[t]{2}{*}{2010} & & Water dilution & 180 & 164 & $172^{\mathrm{QC}: \mathrm{f}}$ \\
\hline & & Water dilution & 81.7 & 74.3 & $78^{Q C: f}$ \\
\hline
\end{tabular}


Table B2-18. Tank 241-S-104 Analytical Results: Cerium (ICP). (2 sheets)

\begin{tabular}{|c|c|c|c|c|c|}
\hline ( hinglo & Gonger & $\begin{array}{l}\text { Ganole } \\
\text { 8\%orion }\end{array}$ & Recili & Byignte & Mean \\
\hline \multicolumn{3}{|c|}{ 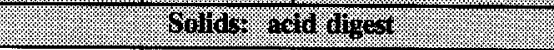 } & 188 & 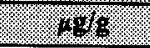 & 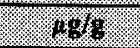 \\
\hline 2088 & \multirow[t]{2}{*}{ 43:2 } & Homogenized Test 1 & $<12.2$ & $<12.2$ & $<12.2$ \\
\hline 2089 & & Homogenized Test 2 & $<12.4$ & 15.3 & $<13.85$ \\
\hline 2092 & \multirow[t]{2}{*}{$43: 4$} & Homogenized Test 1 & 25.1 & 27.5 & 26.3 \\
\hline 2093 & & \begin{tabular}{|l|} 
Homogenized Test 2 \\
\end{tabular} & 33.6 & 26.6 & 30.1 \\
\hline 2096 & \multirow[t]{2}{*}{ 43: 6} & Homogenized Test 1 & 23.3 & 24.1 & 23.7 \\
\hline 2097 & & Homogenized Test 2 & 20.7 & 19 & 19.85 \\
\hline 2171 & \multirow[t]{2}{*}{ Core 42} & Solid composite & 20.4 & 18.4 & 19.4 \\
\hline 2172 & & \begin{tabular}{|l|} 
Solid composite \\
\end{tabular} & 25.1 & 23 & 24.05 \\
\hline 2175 & \multirow[t]{2}{*}{ Core 43} & Solid composite & 29.3 & 25.8 & 27.55 \\
\hline 2176 & & Solid composite & 21.8 & 19.9 & 20.85 \\
\hline 2177 & \multirow[t]{2}{*}{ Core 44} & \begin{tabular}{|l|} 
Solid composite \\
\end{tabular} & 20.3 & 25.3 & 22.8 \\
\hline 2178 & & Solid composite & 16.5 & 19.5 & 18 \\
\hline 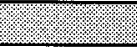 & Sollows & forion: & 2.88 & 988 & $.189 \%$ \\
\hline 2171 & \multirow[t]{2}{*}{ Core 42} & Solid composite & $<49$ & $<49$ & $<49$ \\
\hline 2172 & & \begin{tabular}{|l|} 
Solid composite \\
\end{tabular} & $<48.3$ & $<48.6$ & $<48.45$ \\
\hline 2175 & \multirow[t]{2}{*}{ Core 43} & \begin{tabular}{|l|} 
Solid composite \\
\end{tabular} & $<63.6$ & $<63.2$ & $<63.4$ \\
\hline 2176 & & \begin{tabular}{|l} 
Solid composite \\
\end{tabular} & $<62.7$ & $<62.5$ & $<62.6$ \\
\hline 2177 & \multirow[t]{2}{*}{ Core 44} & \begin{tabular}{|l|} 
Solid composite \\
\end{tabular} & $<42.4$ & $<43$ & $<42.7$ \\
\hline 2178 & & Solid composite & $<42.6$ & $<42.7$ & $<42.65$ \\
\hline & \multicolumn{2}{|c|}{ Sollows r reter olgert } & $2.18 \mathrm{~g} / \mathrm{s}$ & 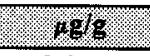 & asf \\
\hline 2171 & \multirow[t]{2}{*}{ Core 42} & Solid composite & $<9.96$ & $<9.9$ & $<9.93$ \\
\hline 2172 & & Solid composite & $<9.96$ & $<10$ & $<9.98$ \\
\hline 2175 & \multirow[t]{2}{*}{ Core 43} & \begin{tabular}{|l|} 
Solid composite \\
\end{tabular} & $<8.6$ & $<8.6$ & $<8.6$ \\
\hline 2176 & & \begin{tabular}{|l|} 
Solid composite \\
\end{tabular} & $<8.7$ & $<8.69$ & $<8.70$ \\
\hline 2177 & \multirow[t]{2}{*}{ Core 44} & \begin{tabular}{|l|} 
Solid composite \\
\end{tabular} & $<8.75$ & $<8.77$ & $<8.76$ \\
\hline 2178 & & Solid composite & $<8.75$ & $<8.76$ & $<8.76$ \\
\hline \multicolumn{3}{|c|}{ Drainals liginity acid digest } & 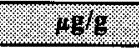 & . 196 & $.99 \mathrm{~g}$ \\
\hline 2247 & 42: 1 & Drainable liquid & $<2.5$ & & $<2.5$ \\
\hline 2249 & 43: 1 & \begin{tabular}{|l|} 
Drainable liquid \\
\end{tabular} & 1 & & 1 \\
\hline 2248 & $44: 1$ & Drainable liquid & 1 & & 1 \\
\hline
\end{tabular}


Table B2-18. Tank 241-S-104 Analytical Results: Cerium (ICP). (2 sheets)

\begin{tabular}{|c|c|c|c|c|c|}
\hline Wompror & 6rand & . & Tesint & OHow & 64011 \\
\hline \multicolumn{3}{|c|}{ 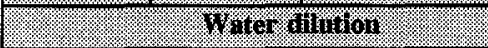 } & (4) & 1496 & $1 \% 8$ \\
\hline 2005 & \multirow[t]{6}{*}{$44: 6$} & Water dilution & $<7.93$ & $<9.8$ & $<8.865$ \\
\hline 2006 & & Water dilution & $<9.92$ & $<9.94$ & $<9.93$ \\
\hline 2007 & & Water dilution & $<9.88$ & $<9.82$ & $<9.85$ \\
\hline 2008 & & Water dilution & $<9.29$ & $<9.34$ & $<9.315$ \\
\hline \multirow[t]{2}{*}{2010} & & Water dilution & $<12.5$ & $<12.7$ & $<12.6$ \\
\hline & & Water dilution & $<8.75$ & $<8.76$ & $<8.755$ \\
\hline
\end{tabular}

Table B2-19. Tank 241-S-104 Analytical Results: Chromium (ICP). (2 sheets)

\begin{tabular}{|c|c|c|c|c|c|}
\hline 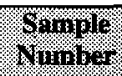 & 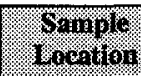 & (6) & titonit & Biplenate. & Hensa \\
\hline & \multicolumn{2}{|c|}{ 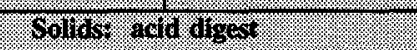 } & 1498 & r. & (40) \\
\hline 2088 & \multirow[t]{2}{*}{$43: 2$} & Homogenized Test 1 & 1,950 & 2,070 & 2,010 \\
\hline 2089 & & Homogenized Test 2 & 2,060 & 2,060 & 2,060 \\
\hline 2092 & \multirow[t]{2}{*}{$43: 4$} & Homogenized Test 1 & 2,510 & 2,450 & $2,480^{\overline{Q C: c}}$ \\
\hline 2093 & & Homogenized Test 2 & 2,340 & 2,250 & $2,295^{\mathrm{QC:c}}$ \\
\hline 2096 & \multirow[t]{2}{*}{$43: 6$} & Homogenized Test 1 & 2,140 & 2,350 & $2,245^{\mathrm{QC:c}}$ \\
\hline 2097 & & Homogenized Test 2 & 2,920 & 2,330 & $2,625^{\mathrm{QC:c}}$ \\
\hline 1171 & \multirow[t]{2}{*}{ Core 42} & Solid composite & 2,550 & 2,490 & $2,520^{\mathrm{QC:c}}$ \\
\hline 2172 & & Solid composite & 2,500 & 2,370 & $2,435^{\mathrm{QC:c}}$ \\
\hline 2175 & \multirow[t]{2}{*}{ Core 43} & Solid composite & 2,290 & 2,190 & 2,240 \\
\hline 2176 & & Solid composite & 2,280 & 2,390 & 2,335 \\
\hline 2177 & \multirow[t]{2}{*}{ Core 44} & Solid composite & 2,170 & 2,200 & 2,185 \\
\hline 2178 & & Solid composite & 2,450 & 2,330 & $2,390^{\mathrm{QC:c}}$ \\
\hline
\end{tabular}


Table B2-19. Tank 241-S-104 Analytical Results: Chromium (ICP). (2 sheets)

\begin{tabular}{|c|c|c|c|c|c|}
\hline $\begin{array}{l}\text { Sampio: } \\
\text { Tianber }\end{array}$ & S.propro & $\begin{array}{l}\text { Sampile } \\
\text { Pontion }\end{array}$ & resiut & Buplicate & Mear. \\
\hline & \multicolumn{2}{|c|}{ 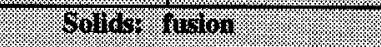 } & 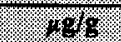 & r. & 4898 \\
\hline 2171 & \multirow[t]{2}{*}{ Core 42} & Solid composite & 2,530 & 2,470 & $2,500^{\mathrm{QC:c}}$ \\
\hline 2172 & & Solid composite & 2,620 & 2,460 & $2,540^{\mathrm{QC}: c}$ \\
\hline 2175 & \multirow[t]{2}{*}{ Core 43} & Solid composite & 2,300 & 2,400 & 2,350 \\
\hline 2176 & & Solid composite & 2,300 & 2,300 & 2,300 \\
\hline 2177 & \multirow[t]{2}{*}{ Core 44} & Solid composite & 2,100 & 2,270 & 2,185 \\
\hline 2178 & & Solid composite & 2,200 & 2,290 & 2,245 \\
\hline 3.2 & \multicolumn{2}{|c|}{ Soline water diget } & 498 & $108 \%$ & $1098 \%$ \\
\hline 2171 & \multirow[t]{2}{*}{ Core 42} & Solid composite & 2,700 & 2,550 & 2,625 \\
\hline 2172 & & Solid composite & 2,680 & 2,420 & 2,550 \\
\hline 2175 & \multirow[t]{2}{*}{ Core 43} & Solid composite & 2,440 & 2,530 & $2,485^{\mathrm{QC:c}}$ \\
\hline 2176 & & Solid composite & 2,540 & 2,610 & $2,575^{\mathrm{QC}: c}$ \\
\hline 2177 & \multirow[t]{2}{*}{ Core 44} & Solid composite & 439 & 724 & 581.5 \\
\hline 2178 & & Solid composite & 685 & 438 & 561.5 \\
\hline \multicolumn{3}{|c|}{ 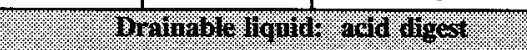 } & 1884 & 198 & 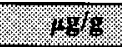 \\
\hline 2247 & 42: 1 & Drainable liquid & 2,800 & & 2,800 \\
\hline 2249 & 43: 1 & Drainable liquid & 2,390 & & 2,390 \\
\hline 2248 & 44: 1 & Drainable liquid & 2,730 & & 2,730 \\
\hline & \multicolumn{2}{|c|}{ Werer divinion } & 198\% & $\mu g(g)$ & $109 / 8$ \\
\hline 2005 & \multirow[t]{5}{*}{ 44: 6} & Water dilution & 2,870 & 2,790 & 2,830 \\
\hline 2006 & & Water dilution & 2,730 & 2,820 & 2,775 \\
\hline 2007 & & Water dilution & 2,730 & 2,780 & 2,755 \\
\hline 2008 & & Water dilution & 3,210 & 2,970 & 3,090 \\
\hline 2010 & & Water dilution & 1,100 & 1,160 & 1,130 \\
\hline
\end{tabular}


Table B2-20. Tank 241-S-104 Analytical Results: Hexavalent Chromium $(\mathrm{Cr}+6)$.

\begin{tabular}{|c|c|c|c|c|c|}
\hline $\begin{array}{l}\text { Samping } \\
\text { Aummber }\end{array}$ & 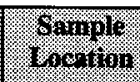 & $\begin{array}{l}\text { Sarrople } \\
\text { Portions }\end{array}$ & Resul: & Buplicate & Mesn \\
\hline 㳖 & \multicolumn{2}{|c|}{ Mater rifingion } & 1.496 & refg & 1.969 \\
\hline 2012 & \multirow[t]{6}{*}{$44: 6$} & Water dilution & 2,690 & 2,600 & 2,645 \\
\hline 2035 & & Water dilution & 2,420 & 2,540 & 2,480 \\
\hline 2155 & & Water dilution & 2,320 & 2,400 & 2,360 \\
\hline 2212 & & Water dilution & 2,440 & 2,400 & 2,420 \\
\hline 2236 & & Water dilution & 960 & 1,180 & 1,070 \\
\hline 2237 & & Water dilution & 3,840 & 4,350 & 4,095 \\
\hline
\end{tabular}

Table B2-21. Tank 241-S-104 Analytical Results: Cobalt (ICP). (2 sheets)

\begin{tabular}{|c|c|c|c|c|c|}
\hline $\begin{array}{l}\text { Shample } \\
\text { Nimina }\end{array}$ & Squplo & $\begin{array}{l}\text { Soingle } \\
\text { remenon }\end{array}$ & nesula & Muplenics & Menal \\
\hline & \multicolumn{2}{|c|}{ 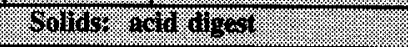 } & $1.8 \%$ & 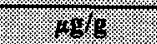 & M.: \\
\hline 2088 & \multirow[t]{2}{*}{$43: 2$} & Homogenized Test 1 & $<1.82$ & 1.97 & $<1.895$ \\
\hline 2089 & & Homogenized Test 2 & $<1.85$ & $<1.81$ & $<1.83$ \\
\hline 2092 & \multirow[t]{2}{*}{$43: 4$} & Homogenized Test 1 & 2.6 & 2.95 & 2.775 \\
\hline 2093 & & Homogenized Test 2 & 2.96 & 2.36 & 2.66 \\
\hline 2096 & \multirow[t]{2}{*}{$43: 6$} & Homogenized Test 1 & 1.89 & 2.66 & 2.28 \\
\hline 2097 & & Homogenized Test 2 & 2.46 & $\overline{3.06}$ & 2.76 \\
\hline 2171 & \multirow[t]{2}{*}{ Core 42} & \begin{tabular}{|l|} 
Solid composite \\
\end{tabular} & 2.62 & 2.49 & 2.56 \\
\hline 2172 & & Solid composite & 3.15 & 2.53 & 2.84 \\
\hline 2175 & \multirow[t]{2}{*}{ Core 43} & Solid composite & 3.03 & 2.3 & 2.67 \\
\hline 2176 & & Solid composite & 2.81 & 2.57 & 2.69 \\
\hline 2177 & \multirow[t]{2}{*}{ Core 44} & Solid composite & 1.8 & 2.1 & 1.95 \\
\hline 2178 & & Solid composite & 2.17 & 2.7 & 2.44 \\
\hline & 6ollors & Hor 101 & 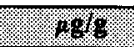 & 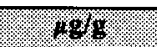 & 1886 \\
\hline 2171 & \multirow[t]{2}{*}{ Core 42} & Solid composite & $<5$ & $<5$ & $<5$ \\
\hline 2172 & & Solid composite & $<4.93$ & $<4.96$ & $<4.95$ \\
\hline 2175 & \multirow[t]{2}{*}{ Core 43} & Solid composite & $<9.44$ & $<9.39$ & $<9.42$ \\
\hline 2176 & & Solid composite & $<9.31$ & $<9.28$ & $<9.30$ \\
\hline 2177 & \multirow[t]{2}{*}{ Core 44} & \begin{tabular}{|l|} 
Solid composite \\
\end{tabular} & $<5.92$ & $<6$ & $<5.96$ \\
\hline 2178 & & Solid composite & $<5.94$ & 7.34 & $<6.64$ \\
\hline
\end{tabular}


HNF-SD-WM-ER-370 Rev. 1

Table B2-21. Tank 241-S-104 Analytical Results: Cobalt (ICP). (2 sheets)

\begin{tabular}{|c|c|c|c|c|c|}
\hline $\begin{array}{l}\text { Sirmple } \\
\text { Nrimier }\end{array}$ & Winging & 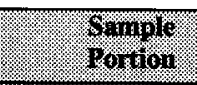 & 2esail & Boplinate & nemin \\
\hline & \multicolumn{2}{|c|}{ 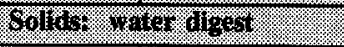 } & (1) 4010 & 1848 & 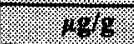 \\
\hline 2171 & \multirow[t]{2}{*}{ Core 42} & Solid composite & $<1.02$ & $<1.01$ & $<1.015$ \\
\hline 2172 & & Solid composite & $<1.02$ & $<1.02$ & $<1.02$ \\
\hline 2175 & \multirow[t]{2}{*}{ Core 43} & Solid composite & $<1.2$ & $<1.2$ & $<1.2$ \\
\hline 2176 & & Solid composite & $<1.21$ & $<1.21$ & $<1.21$ \\
\hline 2177 & \multirow[t]{2}{*}{ Core 44} & Solid composite & $<1.36$ & $<1.22$ & $<1.29$ \\
\hline 2178 & & Solid composite & $<1.22$ & $<1.22$ & $<1 . \overline{22}$ \\
\hline \multicolumn{3}{|c|}{ 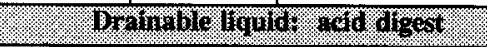 } & 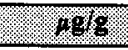 & 488 & 1.989 \\
\hline 2247 & $42: 1$ & Drainable liquid & $<0.37$ & & $<0.37$ \\
\hline 2249 & $43: 1$ & Drainable liquid & 0.17 & & $0.17^{\mathrm{QC:f}}$ \\
\hline 2248 & 44: 1 & Drainable liquid & 0.18 & & $0.18^{\mathrm{QC:f}}$ \\
\hline & \multicolumn{2}{|c|}{ Water divingen } & .096 & (1696 & 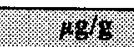 \\
\hline 2005 & \multirow[t]{5}{*}{$44: 6$} & Water dilution & 1.27 & $<1$ & $<1.135$ \\
\hline 2006 & & Water dilution & $<1.01$ & 1.55 & $<1.28$ \\
\hline 2007 & & Water dilution & $<1.01$ & $<1$ & $<1.00$ \\
\hline 2008 & & Water dilution & $<0.95$ & 1.18 & $<1.06^{\mathrm{QCff}}$ \\
\hline 2010 & & Water dilution & $<1.86$ & $<1.88$ & $<1.87$ \\
\hline
\end{tabular}

Table B2-22. Tank 241-S-104 Analytical Results: Copper (ICP). (2 sheets)

\begin{tabular}{|c|c|c|c|c|c|}
\hline $\begin{array}{l}\text { Strmple } \\
\text { Niminger }\end{array}$ & Sample & $\begin{array}{l}\text { Sample } \\
\text { Portion }\end{array}$ & Ienilly & Muringare & Mranin \\
\hline & \multicolumn{2}{|c|}{ 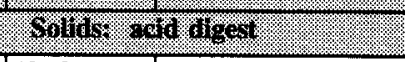 } & 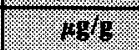 & 486 & 148 \\
\hline 2088 & \multirow[t]{2}{*}{$43: 2$} & Homogenized Test 1 & 10.9 & 11.7 & 11.3 \\
\hline 2089 & & Homogenized Test 2 & 12.3 & 11.4 & 11.85 \\
\hline 2092 & \multirow[t]{2}{*}{$43: 4$} & Homogenized Test 1 & 19.4 & 18.9 & 19.15 \\
\hline 2093 & & Homogenized Test 2 & 21.1 & 19.3 & 20.2 \\
\hline 2096 & \multirow[t]{2}{*}{$43: 6$} & Homogenized Test 1 & 13.2 & 15.9 & 14.55 \\
\hline 2097 & & Homogenized Test 2 & 21.1 & 16.4 & 18.75 \\
\hline 2171 & \multirow[t]{2}{*}{ Core 42} & Solid composite & 31.5 & 31.3 & 31.4 \\
\hline 2172 & & Solid composite & 33.9 & 32.9 & 33.4 \\
\hline
\end{tabular}


Table B2-22. Tank 241-S-104 Analytical Results: Copper (ICP). (2 sheets)

\begin{tabular}{|c|c|c|c|c|c|}
\hline $\begin{array}{l}\text { Gampole. } \\
\text { Yumber }\end{array}$ & $\begin{array}{l}\text { Sample: } \\
\text { fecation. }\end{array}$ & $\begin{array}{l}\text { Seranplos } \\
\text { fortion }\end{array}$ & Resilit & Buplicite & : Vhern. \\
\hline & \multicolumn{2}{|c|}{ 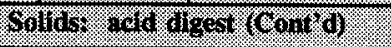 } & 1 & 160 & (6) \\
\hline 2175 & \multirow[t]{2}{*}{ Core 43} & Solid composite & 13.5 & 12.4 & 12.95 \\
\hline 2176 & & Solid composite & 12.5 & 12.2 & 12.35 \\
\hline 2177 & \multirow[t]{2}{*}{ Core 44} & Solid composite & 13.5 & 13.9 & 13.7 \\
\hline 2178 & & Solid composite & 13 & 12.5 & 12.75 \\
\hline & Solvor & 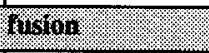 & $\sqrt{1086}$ & 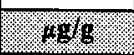 & 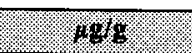 \\
\hline 2171 & \multirow[t]{2}{*}{ Core 42} & Solid composite & 56.7 & 61.9 & 59.3 \\
\hline 2172 & & Solid composite & 37 & 110 & 73.5 \\
\hline 2175 & \multirow[t]{2}{*}{ Core 43} & Solid composite & 85.4 & 37.7 & 61.55 \\
\hline 2176 & & Solid composite & 32.8 & 30.3 & 31.55 \\
\hline 2177 & \multirow[t]{2}{*}{ Core 44} & Solid composite & 63.1 & 80.4 & 71.75 \\
\hline 2178 & & Solid composite & 35.7 & 25.7 & 30.7 \\
\hline & \multicolumn{2}{|c|}{ Solids: yater digesi } & $1.48 \%$ & 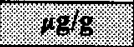 & 1980. \\
\hline 2171 & \multirow[t]{2}{*}{ Core 42} & Solid composite & 0.832 & 8.88 & 4.856 \\
\hline 2172 & & Solid composite & 1.35 & 1.32 & 1.335 \\
\hline 2175 & \multirow[t]{2}{*}{ Core 43} & Solid composite & 0.691 & $<0.6$ & $<0.65$ \\
\hline 2176 & & Solid composite & 0.621 & $<0.606$ & $<0.61$ \\
\hline 2177 & \multirow[t]{2}{*}{ Core 44} & Solid composite & $<0.611$ & $<0.612$ & $<0.61$ \\
\hline 2178 & & Solid composite & 0.945 & $<0.611$ & $<0.78$ \\
\hline$\overline{1}$ & \multicolumn{2}{|c|}{ 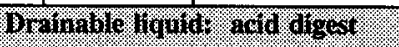 } & 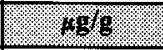 & 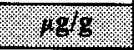 & . $48 / 6$ \\
\hline 2247 & 42: 1 & Drainable liquid & $<0.117188$ & & $<0.117188^{\mathrm{QC}: \mathrm{f}}$ \\
\hline 2249 & 43: 1 & Drainable liquid & 0.247656 & & $0.247656^{\mathrm{QC}: \mathrm{f}}$ \\
\hline 2248 & $44: 1$ & Drainable liquid & 0.142187 & & $0.142187^{\text {QC:f }}$ \\
\hline \multicolumn{3}{|c|}{ Worar difition } & 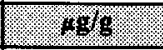 & 2.096 & $10 \%$ \\
\hline 2005 & \multirow[t]{5}{*}{$44: 6$} & Water dilution & $<0.324$ & $<0.4$ & $<0.36$ \\
\hline 2006 & & Water dilution & $<0.405$ & $<0.406$ & $<0.41$ \\
\hline 2007 & & Water dilution & $<0.403$ & $<0.401$ & $<0.40$ \\
\hline 2008 & & Water dilution & $<0.379$ & $<0.381$ & $<0.38$ \\
\hline 2010 & & Water dilution & $<0.586$ & $<0.593$ & $<0.59^{\mathrm{QC}: \mathrm{f}}$ \\
\hline
\end{tabular}


Table B2-23. Tank 241-S-104 Analytical Results: Iron (ICP). (2 sheets)

\begin{tabular}{|c|c|c|c|c|c|}
\hline $\begin{array}{l}\text { Sumple } \\
\text { Nimimer }\end{array}$ & 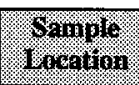 & $\begin{array}{l}\text { Sarngie: } \\
\text { Eotion }\end{array}$ & Resulit: & Buplicito & Mean \\
\hline & \multicolumn{2}{|c|}{ Siller jerd nigest } & 1096 & 198 & 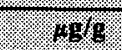 \\
\hline 2088 & \multirow[t]{2}{*}{$43: 2$} & Homogenized Test 1 & 1,590 & 1,580 & $1,590^{\mathrm{OC}: \mathrm{c}}$ \\
\hline 2089 & & Homogenized Test 2 & 1,400 & 712 & $1,060^{\mathrm{QC}: \mathrm{c}}$ \\
\hline 2092 & \multirow[t]{2}{*}{ 43: 4} & Homogenized Test 1 & 1,100 & 1,470 & $1,290^{\mathrm{QC}: \mathrm{c}}$ \\
\hline 2093 & & Homogenized Test 2 & 1,660 & 1,230 & $1,450^{\mathrm{QC}: \mathrm{c}}$ \\
\hline 2096 & \multirow[t]{2}{*}{$43: 6$} & Homogenized Test 1 & 751 & 1,010 & 880 \\
\hline 2097 & & Homogenized Test 2 & 758 & 849 & 803 \\
\hline 2171 & \multirow[t]{2}{*}{ Core 42} & Solid composite & 755 & 617 & 686 \\
\hline 2172 & & Solid composite & 850 & 958 & 904 \\
\hline 2175 & \multirow[t]{2}{*}{ Core 43} & Solid composite & 617 & 639 & 628 \\
\hline 2176 & & Solid composite & 656 & 620 & 638 \\
\hline 2177 & \multirow[t]{2}{*}{ Core 44} & Solid composite & 1,030 & 1,080 & 1,060 \\
\hline 2178 & & Solid composite & 740 & 686 & 713 \\
\hline
\end{tabular}


Table B2-23. Tank 241-S-104 Analytical Results: Iron (ICP). (2 sheets)

\begin{tabular}{|c|c|c|c|c|c|}
\hline $\begin{array}{l}\text { Simple } \\
\text { Nimber }\end{array}$ & $\begin{array}{l}\text { Sormpite } \\
\text { Yocation }\end{array}$ & $\begin{array}{l}\text { Sarigite } \\
\text { rention }\end{array}$ & Terait & Duplicate & Urai: \\
\hline & Solligy & figron & 486 & . & whe \\
\hline 2171 & \multirow[t]{2}{*}{ Core 42} & Solid composite & 1,560 & 1,450 & $1,505^{\mathrm{QC}: \mathrm{c}}$ \\
\hline 2172 & & Solid composite & 1,900 & 1,630 & $1,765^{\mathrm{QC}: \mathrm{c}}$ \\
\hline 2175 & \multirow[t]{2}{*}{ Core 43} & Solid composite & 1,740 & 1,810 & 1,775 \\
\hline 2176 & & Solid composite & 1,760 & 1,690 & 1,725 \\
\hline 2177 & \multirow[t]{2}{*}{ Core 44} & Solid composite & 1,660 & 1,850 & 1,755 \\
\hline 2178 & & Solid composite & 1,670 & 1,860 & 1,765 \\
\hline 斻 & \multicolumn{2}{|c|}{ Sollots: water digert } & 486 & $148 \%$ & 4.968 \\
\hline 2171 & \multirow[t]{2}{*}{ Core 42} & Solid composite & 4.18 & 106 & 55.09 \\
\hline 2172 & & Solid composite & 3.26 & 13.5 & 8.38 \\
\hline 2175 & \multirow[t]{2}{*}{ Core 43} & Solid composite & 3.76 & $\overline{<2}$ & $<2.88$ \\
\hline 2176 & & Solid composite & 4.59 & 3.24 & 3.915 \\
\hline 2177 & \multirow[t]{2}{*}{ Core 44} & Solid composite & $<2.04$ & $<2.04$ & $<2.04$ \\
\hline 2178 & & Solid composite & $<2.04$ & $<2.04$ & $<2.04$ \\
\hline \multicolumn{3}{|c|}{ 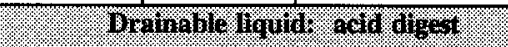 } & 1986 & 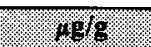 & 488 \\
\hline 2247 & 42:1 & Drainable liquid & 3.18 & & $3.18^{\mathrm{OC}: \mathrm{f}}$ \\
\hline 2248 & 43: 1 & Drainable liquid & 2.22 & & 2.22 \\
\hline 2249 & $44: 1$ & Drainable liquid & 3.45 & & 3.45 \\
\hline 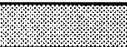 & \multicolumn{2}{|c|}{ Wheralingin } & $178 / \mathrm{s}$ & $9.96 \%$ & $1.89 \mathrm{~g}$ \\
\hline 2005 & \multirow[t]{5}{*}{ 44: 6} & Water dilution & $<1.21$ & $<1.5$ & $<1.36$ \\
\hline 2006 & & Water dilution & $<1.52$ & $<1.52$ & $<1.52$ \\
\hline 2007 & & Water dilution & 1.99 & $<1.5$ & $<1.75^{\text {QC:f }}$ \\
\hline 2008 & & Water dilution & $<1.42$ & $<1.43$ & $<1.43$ \\
\hline 2010 & & Water dilution & 1.66 & $<1.58$ & $<1.62$ \\
\hline
\end{tabular}


Table B2-24. Tank 241-S-104 Analytical Results: Lanthanum (ICP).

(2 sheets)

\begin{tabular}{|c|c|c|c|c|c|}
\hline . & 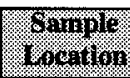 & 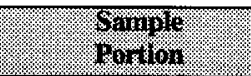 & isesul & 9indicare & $462 n$ \\
\hline & \multicolumn{2}{|c|}{ 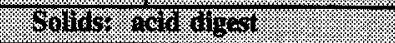 } & \% & V.if & $6 \mathrm{so}$ \\
\hline 2088 & \multirow[t]{2}{*}{$43: 2$} & Homogenized Test 1 & $<1.91$ & $<1.91$ & $<1.91$ \\
\hline 2089 & & Homogenized Test 2 & $<1.94$ & $<1.9$ & $<1.92$ \\
\hline 2092 & \multirow[t]{2}{*}{$43: 4$} & Homogenized Test 1 & $<1.92$ & $<2.03$ & $<1.975$ \\
\hline 2093 & & Homogenized Test 2 & $<2.06$ & $<2.1$ & $<2.08$ \\
\hline 2096 & \multirow[t]{2}{*}{$43: 6$} & Homogenized Test 1 & $<1.59$ & $<1.51$ & $<1.55$ \\
\hline 2097 & & Homogenized Test 2 & $<3.13$ & $<2.71$ & $<2.92$ \\
\hline 2171 & \multirow[t]{2}{*}{ Core 42} & Solid composite & $<1.53$ & $<1.55$ & $<1.54$ \\
\hline 2172 & & Solid composite & $<1.58$ & $<1.53$ & $<1.555$ \\
\hline $217 \overline{5}$ & \multirow[t]{2}{*}{ Core 43} & Solid composite & $<2.03$ & $<2$ & $<2.02$ \\
\hline 2176 & & Solid composite & $<2.06$ & $<2.07$ & $<2.07$ \\
\hline 2177 & \multirow[t]{2}{*}{ Core 44} & Solid composite & $<2.07$ & $<2.02$ & $<2.05$ \\
\hline 2178 & & Solid composite & $<2.03$ & $<2$ & $<2.02$ \\
\hline & \multicolumn{2}{|c|}{ 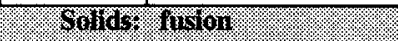 } & (16) & 485 & W. \\
\hline 2171 & \multirow[t]{2}{*}{ Core 42} & Solid composite & $<8$ & $<8$ & $<8$ \\
\hline 2172 & & Solid composite & $<7.89$ & $<7.94$ & $<7.92$ \\
\hline 2175 & \multirow[t]{2}{*}{ Core 43} & Solid composite & $<9.94$ & $<9.88$ & $<9.91$ \\
\hline 2176 & & Solid composite & $<9.8$ & $<9.77$ & $<9.79$ \\
\hline 2177 & \multirow[t]{2}{*}{ Core 44} & Solid composite & $<10.4$ & $<10.5$ & $<10.45$ \\
\hline 2178 & & Solid composite & $<10.4$ & $<10.4$ & $<10.4$ \\
\hline & \multicolumn{2}{|c|}{ 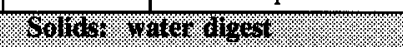 } & 189 & 188 & 108 \\
\hline 2171 & \multirow[t]{2}{*}{ Core 42} & Solid composite & $<1.63$ & $<1.62$ & $<1.63$ \\
\hline 2172 & & Solid composite & $<1.63$ & $<1.63$ & $<1.63$ \\
\hline 2175 & \multirow[t]{2}{*}{ Core 43} & Solid composite & $<2.1$ & $<2.1$ & $<2.1$ \\
\hline 2176 & & Solid composite & $<2.12$ & $<2.12$ & $<2.12$ \\
\hline 2177 & \multirow[t]{2}{*}{ Core 44} & Solid composite & $<2.14$ & $<2.14$ & $<2.14$ \\
\hline 2178 & & Solid composite & $<2.14$ & $<2.14$ & $<2.14$ \\
\hline \multicolumn{3}{|c|}{ 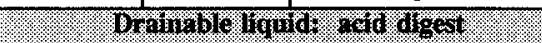 } & 149 & $x_{5}$ & , m \\
\hline 2247 & $42: 1$ & Drainable liquid & $<0.39$ & & $<0.39$ \\
\hline 2249 & 43: 1 & Drainable liquid & 0.21 & & 0.21 \\
\hline 2248 & $44: 1$ & Drainable liquid & 0.19 & & 0.19 \\
\hline
\end{tabular}


Table B2-24. Tank 241-S-104 Analytical Results: Lanthanum (ICP). (2 sheets)

\begin{tabular}{|c|c|c|c|c|c|}
\hline $\begin{array}{l}\text { ormingle } \\
\text { Number. }\end{array}$ & Sowringe & $\begin{array}{l}\text { Siriupio } \\
\text { Portion }\end{array}$ & Ressill & Duplicare. & Near \\
\hline 1. & \multicolumn{2}{|c|}{ Whor oriluron } & $6 \%$ & m86 & Feger \\
\hline 2005 & \multirow[t]{5}{*}{$44: 6$} & Water dilution & $<1.3$ & $<1.6$ & $<1.45$ \\
\hline 2006 & & Water dilution & $<1.62$ & $<1.62$ & $<1.62$ \\
\hline 2007 & & Drainable liquid & $<1.61$ & $<1.6$ & $<1.61$ \\
\hline 2008 & & Water dilution & $<1.52$ & $<1.53$ & $<1.53$ \\
\hline 2010 & & Water dilution & $<1.95$ & $<1.98$ & $<1.96$ \\
\hline
\end{tabular}

Table B2-25. Tank 241-S-104 Analytical Results: Lead (ICP). (2 sheets)

\begin{tabular}{|c|c|c|c|c|c|}
\hline $\begin{array}{l}\text { Sample: } \\
\text { tumber. }\end{array}$ & $\begin{array}{l}\text { Simple } \\
\text { Uroution }\end{array}$ & $\begin{array}{l}\text { Sample } \\
\text { Inotion }\end{array}$ & resinin & $84010 \% 14$ & 148. \\
\hline ?.: & \multicolumn{2}{|c|}{ Solmis. \% cit org ar } & 1486 & 1.86 & 4818 \\
\hline 2088 & \multirow[t]{2}{*}{$43: 2$} & Homogenized Test 1 & 19.4 & 25.5 & 22.45 \\
\hline 2089 & & Homogenized Test 2 & 20.1 & 19.6 & 19.85 \\
\hline 2092 & \multirow[t]{2}{*}{$43: 4$} & Homogenized Test 1 & 45.2 & $<8.23$ & $<26.72$ \\
\hline 2093 & & Homogenized Test 2 & $<8.35$ & $<8.5$ & $<8.43$ \\
\hline 2096 & \multirow[t]{2}{*}{ 43: 6} & Homogenized Test 1 & $<7.04$ & $<6.69$ & $<6.87$ \\
\hline 2097 & & Homogenized Test 2 & 29.9 & $<11$ & $<20.45$ \\
\hline 2171 & \multirow[t]{2}{*}{ Core 42} & Solid composite & 37.3 & 43.6 & 40.45 \\
\hline 2172 & & Solid composite & 42.6 & 16.3 & $29 . \overline{45}$ \\
\hline 2175 & \multirow[t]{2}{*}{ Core 43} & Solid composite & 36.6 & 52.1 & 44.35 \\
\hline 2176 & & Solid composite & 11.9 & 15.6 & 13.75 \\
\hline 2177 & \multirow[t]{2}{*}{ Core 44} & Solid composite & $<8.37$ & $<8.17$ & $<8.27$ \\
\hline 2178 & & Solid composite & 21.4 & 18.1 & 19.75 \\
\hline
\end{tabular}


Table B2-25. Tank 241-S-104 Analytical Results: Lead (ICP). (2 sheets)

\begin{tabular}{|c|c|c|c|c|c|}
\hline 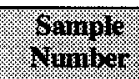 & $\begin{array}{l}\text { Gamplo } \\
\text { frocesion }\end{array}$ & $\begin{array}{l}\text { Spariple } \\
\text { Tomthor }\end{array}$ & Megull & Buplicist & yigin \\
\hline 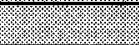 & Sollo & Usion & 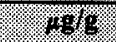 & 896 & 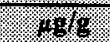 \\
\hline 2171 & \multirow[t]{2}{*}{ Core 42} & Solid composite & $<35.5$ & $<35.5$ & $<35.5$ \\
\hline 2172 & & Solid composite & $<35$ & $<35.2$ & $<35.1$ \\
\hline 2175 & \multirow[t]{2}{*}{ Core 43} & Solid composite & $<38.8$ & $<38.5$ & $<38.65$ \\
\hline 2176 & & Solid composite & $<38.2$ & $<38.1$ & $<38.15$ \\
\hline 2177 & \multirow[t]{2}{*}{ Core 44} & Solid composite & $<41.9$ & $<42.5$ & $<42.2$ \\
\hline 2178 & & Solid composite & $<42.1$ & $<42.2$ & $<42.15$ \\
\hline ? & \multicolumn{2}{|c|}{ Soldos wathe digest } & 488 & 1808 & 1898 \\
\hline 2171 & \multirow[t]{2}{*}{ Core 42} & Solid composite & $<7.21$ & $<7.17$ & $<7.19$ \\
\hline 2172 & & Solid composite & $<7.21$ & $<7.24$ & $<7.225$ \\
\hline 2175 & \multirow[t]{2}{*}{ Core 43} & Solid composite & $<8.5$ & $<8.5$ & $<8.5$ \\
\hline 2176 & & Solid composite & $<8.6$ & $<8.58$ & $<8.59$ \\
\hline 2177 & \multirow[t]{2}{*}{ Core 44} & Solid composite & $<8.65$ & $<8.67$ & $<8.66$ \\
\hline 2178 & & Solid composite & $<8.65$ & $<8.66$ & $<8.66$ \\
\hline & \multicolumn{2}{|c|}{ Brainuble liguide acid diges) } & 198\% & $48 \times$ & 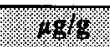 \\
\hline 2247 & 42: 1 & Drainable liquid & 13.52 & & 13.52 \\
\hline 2248 & 43: 1 & Drainable liquid & 7.59 & & $7.59^{\mathrm{QC}: \mathrm{f}}$ \\
\hline 2249 & 44: 1 & Drainable liquid & 9.61 & & $9.61^{\mathrm{QC}: \mathrm{f}}$ \\
\hline \multicolumn{3}{|c|}{ 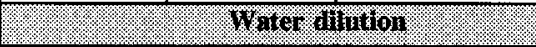 } & 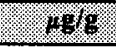 & $48 \%$ & (4) \\
\hline 2005 & \multirow[t]{5}{*}{$44: 6$} & Water dilution & $<5.75$ & $<7.1$ & $<6.43$ \\
\hline 2006 & & Water dilution & $<7.18$ & $<7.2$ & $<7.19$ \\
\hline 2007 & & Water dilution & $<7.16$ & $<7.11$ & $<7.14$ \\
\hline 2008 & & Water dilution & $<6.73$ & $<6.77$ & $<6.75$ \\
\hline 2010 & & Water dilution & $<7.62$ & $<7.71$ & $<7.67$ \\
\hline
\end{tabular}


Table B2-26. Tank 241-S-104 Analytical Results: Magnesium (ICP). (2 sheets)

\begin{tabular}{|c|c|c|c|c|c|}
\hline 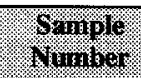 & Whanio & Gomplo & 92.111 & Bropleyso & . \\
\hline & \multicolumn{2}{|c|}{ 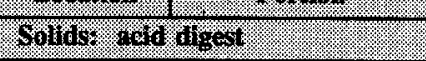 } & 48 & 28 & 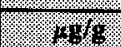 \\
\hline 2088 & \multirow[t]{2}{*}{ 43: 2} & Homogenized Test 1 & 44.7 & 46.7 & 45.7 \\
\hline 2089 & & Homogenized Test 2 & 40.8 & 67.6 & 54.2 \\
\hline 2092 & \multirow[t]{2}{*}{$43: 4$} & Homogenized Test 1 & 65.3 & 73.8 & 69.55 \\
\hline 2093 & & Homogenized Test 2 & 73.5 & 64.6 & 69.05 \\
\hline 2096 & \multirow[t]{2}{*}{$43: 6$} & Homogenized Test 1 & 27.4 & 32.9 & 30.15 \\
\hline 2097 & & Homogenized Test 2 & 30.3 & 28.8 & 29.55 \\
\hline 2171 & \multirow[t]{2}{*}{ Core 42} & Solid composite & 33.7 & 33.9 & 33.8 \\
\hline 2172 & & Solid composite & 36.3 & 39.4 & 37.85 \\
\hline 2175 & \multirow[t]{2}{*}{ Core 43} & Solid composite & 38.4 & 35.1 & 36.75 \\
\hline 2176 & & Solid composite & 45.2 & 39.8 & 42.5 \\
\hline 2177 & \multirow[t]{2}{*}{ Core 44} & Solid composite & 58.7 & 58.3 & 58.5 \\
\hline 2178 & & Solid composite & 51.6 & 42.9 & 47.25 \\
\hline & \multicolumn{2}{|c|}{ 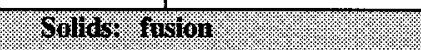 } & ity & 8\% & 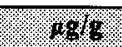 \\
\hline 2171 & \multirow[t]{2}{*}{ Core 42} & Solid composite & 80.5 & 69.4 & 74.95 \\
\hline 2172 & & Solid composite & 79.3 & 76.1 & 77.7 \\
\hline 2175 & \multirow[t]{2}{*}{ Core 43} & Solid composite & 92.5 & 91.4 & 91.95 \\
\hline 2176 & & Solid composite & 109 & 89.9 & 99.45 \\
\hline 2177 & \multirow[t]{2}{*}{ Core 44} & Solid composite & 150 & 149 & 149.5 \\
\hline 2178 & & Solid composite & 709 & 185 & 447 \\
\hline & \multicolumn{2}{|c|}{ Golings yoter digest } & 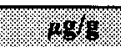 & 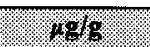 & $8 \mathrm{~s}$ \\
\hline 2171 & \multirow[t]{2}{*}{ Core 42} & Solid composite & 2.44 & 44.5 & 23.47 \\
\hline 2172 & & Solid composite & 1.89 & 5.76 & 3.83 \\
\hline 2175 & \multirow[t]{2}{*}{ Core 43} & Solid composite & 6.39 & 7.99 & 7.19 \\
\hline 2176 & & Solid composite & 6.15 & 6.1 & 6.13 \\
\hline 2177 & \multirow[t]{2}{*}{ Core 44} & Solid composite & 4.93 & 5.09 & 5.01 \\
\hline 2178 & & Solid composite & 5.11 & 3.74 & 4.43 \\
\hline \multicolumn{2}{|c|}{ Branjule Haull } & arologor & 9618 & 18: & . \\
\hline 2247 & $42: 1$ & Drainable liquid & 0.69 & & $0.69^{\mathrm{Qcf}}$ \\
\hline 2249 & 43: 1 & Drainable liquid & 0.17 & & 0.17 \\
\hline 2248 & 44: 1 & Drainable liquid & $<0.34$ & & $<0.34$ \\
\hline
\end{tabular}


HNF-SD-WM-ER-370 Rev. 1

Table B2-26. Tank 241-S-104 Analytical Results: Magnesium (ICP). (2 sheets)

\begin{tabular}{|c|c|c|c|c|c|}
\hline $\begin{array}{l}\text { Simine: } \\
\text { furnter. }\end{array}$ & $\begin{array}{l}\text { Shimple } \\
\text { Tocmion }\end{array}$ & $\begin{array}{l}\text { Sample } \\
\text { Sortion }\end{array}$ & Resull & Dopllesise & Hero \\
\hline & \multicolumn{2}{|c|}{ Wate divirion } & 1786 & $40 \% 8$ & 140 4 \\
\hline 2005 & \multirow[t]{5}{*}{ 44: 6} & Water dilution & 2.23 & 2.97 & $2.6^{\text {QC:f }}$ \\
\hline 2006 & & Water dilution & 22.9 & 2.63 & $12.77^{\mathrm{QC:f}}$ \\
\hline 2007 & & Water dilution & 2.86 & 2.85 & $2.86^{\mathrm{QC}: \mathrm{f}}$ \\
\hline 2008 & & Water dilution & 2.04 & 1.99 & $2.02^{\text {oC:f }}$ \\
\hline 2010 & & Water dilution & 6.25 & 5.94 & $6.10^{\mathrm{QC:f}}$ \\
\hline
\end{tabular}

Table B2-27. Tank 241-S-104 Analytical Results: Manganese (ICP). (2 sheets)

\begin{tabular}{|c|c|c|c|c|c|}
\hline 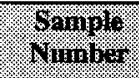 & $\begin{array}{l}\text { Sumple } \\
\text { Eorition }\end{array}$ & $\begin{array}{l}\text { Semplo } \\
\text { Partion }\end{array}$ & Resintit & Grollemes: & Miean \\
\hline 2 & \multicolumn{2}{|c|}{ 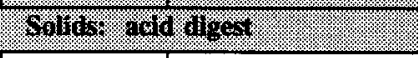 } & (18) & . $\mathrm{ggh}$ & 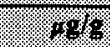 \\
\hline 2088 & \multirow[t]{2}{*}{$43: 2$} & Homogenized Test 1 & 1,030 & 1,100 & 1,065 \\
\hline 2089 & & Homogenized Test 2 & 1,100 & 1,090 & 1,095 \\
\hline 2092 & \multirow[t]{2}{*}{ 43: 4} & Homogenized Test 1 & 2,320 & 2,280 & $2,300^{\mathrm{eC:c}}$ \\
\hline 2093 & & Homogenized Test 2 & 2,310 & 2,170 & $2,240^{\mathrm{QC}: \mathrm{c}}$ \\
\hline 2096 & \multirow[t]{2}{*}{$43: 6$} & Homogenized Test 1 & 28.7 & 34.1 & 31.4 \\
\hline 2097 & & Homogenized Test 2 & 72.1 & 28 & 50 \\
\hline 2171 & \multirow[t]{2}{*}{ Core 42} & Solid composite & 681 & 905 & 793 \\
\hline 2172 & & Solid composite & 813 & 760 & 787 \\
\hline 2175 & \multirow[t]{2}{*}{ Core 43} & Solid composite & 835 & 710 & $773^{\mathrm{OC} ; \mathrm{c}}$ \\
\hline 2176 & & Solid composite & 838 & 783 & $811^{\mathrm{QC}: \mathrm{c}}$ \\
\hline 2177 & \multirow[t]{2}{*}{ Core 44} & Solid composite & 1,340 & 1,310 & $1,330^{\mathrm{QC:c}}$ \\
\hline 2178 & & Solid composite & 1,100 & 1,050 & 1,080 \\
\hline
\end{tabular}


HNF-SD-WM-ER-370 Rev. 1

Table B2-27. Tank 241-S-104 Analytical Results: Manganese (ICP). (2 sheets)

\begin{tabular}{|c|c|c|c|c|c|}
\hline $\begin{array}{l}\text { Saringle } \\
\text { Numoloet }\end{array}$ & $\begin{array}{l}\text { Sample } \\
\text { Losation }\end{array}$ & $\begin{array}{l}\text { Simple } \\
\text { Portion. }\end{array}$ & resuif & Buplicale & Mean \\
\hline l, & \multicolumn{2}{|c|}{ Golder Tysion } & $94 / 8$ & 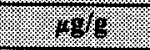 & 1084 \\
\hline 2171 & \multirow[t]{2}{*}{ Core 42} & Solid composite & 815 & 1,090 & $953^{\mathrm{QC}: \mathrm{c}}$ \\
\hline 2172 & & Solid composite & 1,220 & 1,130 & $1,180^{\mathrm{QC}: \mathrm{c}}$ \\
\hline 2175 & \multirow[t]{2}{*}{ Core 43} & Solid composite & 1,070 & 990 & 1,030 \\
\hline 2176 & & Solid composite & 653 & 583 & 618 \\
\hline 2177 & \multirow[t]{2}{*}{ Core 44} & Solid composite & 1,520 & 1,960 & 1,740 \\
\hline 2178 & & Solid composite & 1,290 & 1,480 & 1,390 \\
\hline & \multicolumn{2}{|c|}{ 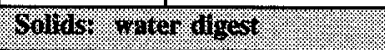 } & 2868 & $48 \mathrm{~s} / \mathrm{s}$ & 1.968 \\
\hline 2171 & \multirow[t]{2}{*}{ Core 42} & Solid composite & $<0.31$ & 2.58 & $<1.44$ \\
\hline 2172 & & Solid composite & $<0.31$ & 0.51 & $<0.41$ \\
\hline 2175 & \multirow[t]{2}{*}{ Core 43} & Solid composite & $<0.3$ & $<0.3$ & $<0.3$ \\
\hline 2176 & & Solid composite & $<0.30$ & $<0.3$ & $<0.30$ \\
\hline 2177 & \multirow[t]{2}{*}{ Core 44} & Solid composite & $<0.31$ & $<0.31$ & $<0.31$ \\
\hline 2178 & & Solid composite & $<0.31$ & $<0.31$ & $<0.31$ \\
\hline 放 & \multicolumn{2}{|c|}{ 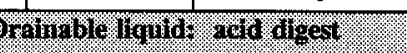 } & 1886 & 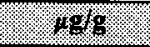 & 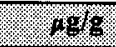 \\
\hline 2247 & 42: 1 & Drainable liquid & $<0.059$ & & $<0.059$ \\
\hline 2249 & $43: 1$ & Drainable liquid & $<0.031$ & & $<0.031$ \\
\hline 2248 & 44: 1 & Drainable liquid & $<0.023$ & & $<0.023$ \\
\hline & \multicolumn{2}{|c|}{ Wraer dilliguron } & $1 \times 8 / 8$ & 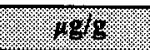 & 498 \\
\hline 2005 & \multirow[t]{5}{*}{ 44: 6} & Water dilution & $<0.24$ & $<0.3$ & $<0.27$ \\
\hline 2006 & & Water dilution & 0.74 & $<0.30$ & $<0.52$ \\
\hline 2007 & & Water dilution & $<0.30$ & $<0.30$ & $<0.30$ \\
\hline 2008 & & Water dilution & $<0.28$ & $<0.29$ & $<0.29$ \\
\hline 2010 & & Water dilution & $<0.29$ & $<0.30$ & $<0.29$ \\
\hline
\end{tabular}


Table B2-28. Tank 241-S-104 Analytical Results: Mercury (CVAA).

\begin{tabular}{|c|c|c|c|c|c|}
\hline Ganiplo & 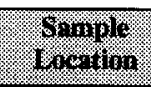 & $\begin{array}{l}\text { Sample } \\
\text { Portion. }\end{array}$ & Resull & Buplicure & Yeran \\
\hline 2.8. & Solg & (2) & 4.18 & (4) & $8 \%$ \\
\hline 2171 & \multirow[t]{2}{*}{ Core 42} & Solid composite & $<0.123$ & $<0.126$ & $<0.1245$ \\
\hline 2172 & & Solid composite & $<0.126$ & $<0.121$ & $<0.1235$ \\
\hline 2175 & \multirow[t]{2}{*}{ Core 43} & Solid composite & $<0.125$ & $<0.125$ & $<0.125$ \\
\hline 2176 & & Solid composite & $<0.125$ & $<0.125$ & $<0.125$ \\
\hline 2177 & \multirow[t]{2}{*}{\begin{tabular}{|l} 
Core 44 \\
\end{tabular}} & Solid composite & $<0.125$ & $<0.125$ & $<0.125$ \\
\hline 2178 & & Solid composite & $<0.125$ & $<0.125$ & $<0.125$ \\
\hline
\end{tabular}

Table B2-29. Tank 241-S-104 Analytical Results: Nickel (ICP). (2 sheets)

\begin{tabular}{|c|c|c|c|c|c|}
\hline $\begin{array}{l}\text { Sample } \\
\text { Number }\end{array}$ & $\begin{array}{l}\text { Sample } \\
\text { Sosation }\end{array}$ & $\begin{array}{l}\text { Shanple } \\
\text { Iontuon }\end{array}$ & Ienain & Hiplicati: & Mean \\
\hline & \multicolumn{2}{|c|}{ 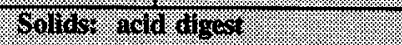 } & 189 & 48 & 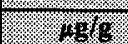 \\
\hline 2088 & \multirow[t]{2}{*}{$43: 2$} & Homogenized Test 1 & 38.5 & 41 & 39.75 \\
\hline 2089 & & Homogenized Test 2 & 41.7 & 41.3 & 41.5 \\
\hline 2092 & \multirow[t]{2}{*}{$43: 4$} & Homogenized Test 1 & 93.3 & 94.7 & 94 \\
\hline 2093 & & Homogenized Test 2 & 97.8 & 88 & 92.9 \\
\hline 2096 & \multirow[t]{2}{*}{$43: 6$} & Homogenized Test 1 & 43.5 & 55.2 & 49.35 \\
\hline 2097 & & \begin{tabular}{|l|} 
Homogenized Test 2 \\
\end{tabular} & 47.5 & 50.8 & 49.15 \\
\hline 2171 & \multirow[t]{2}{*}{ Core 42} & Solid composite & 52 & 50.3 & 51.15 \\
\hline 2172 & & Solid composite & 57.3 & 58.5 & 57.9 \\
\hline 2175 & \multirow[t]{2}{*}{ Core 43} & Solid composite & 52 & 47.9 & 49.95 \\
\hline 2176 & & Solid composite & 55.3 & 55.8 & 55.55 \\
\hline 2177 & \multirow[t]{2}{*}{ Core 44} & \begin{tabular}{|l|} 
Solid composite \\
\end{tabular} & 65.6 & 68.7 & 67.15 \\
\hline 2178 & & Solid composite & 56.7 & 52.1 & 54.4 \\
\hline 9. & \multicolumn{2}{|c|}{ 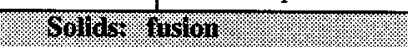 } & 1486 & $1.6 \% 8$ & 1898 \\
\hline 2171 & \multirow[t]{2}{*}{ Core 42} & Solid composite & 4,260 & 5,350 & $4,805^{\mathrm{QC:c}}$ \\
\hline 2172 & & Solid composite & 5,160 & 4,580 & $4,870^{\mathrm{QC:c}}$ \\
\hline 2175 & \multirow[t]{2}{*}{ Core 43} & Solid composite & 5,910 & 5,190 & 5,550 \\
\hline 2176 & & Solid composite & 5,420 & 4,310 & 4,865 \\
\hline 2177 & \multirow[t]{2}{*}{ Core 44} & Solid composite & 5,750 & 2,880 & 4,315 \\
\hline 2178 & & Solid composite & 2,800 & 8,460 & 5,630 \\
\hline
\end{tabular}


Table B2-29. Tank 241-S-104 Analytical Results: Nickel (ICP). (2 sheets)

\begin{tabular}{|c|c|c|c|c|c|}
\hline 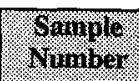 & ong & 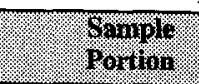 & Iesinil & B11011\%,o & Men \\
\hline & \multicolumn{2}{|c|}{ 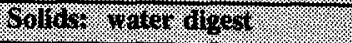 } & 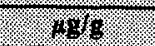 & $48 \%$ & 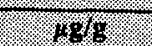 \\
\hline 2171 & \multirow[t]{2}{*}{ Core 42} & Solid composite & $<1.42$ & 1.78 & $<1.6$ \\
\hline $21 \overline{72}$ & & Solid composite & $<1.42$ & 1.61 & $<1.52$ \\
\hline $2 \overline{175}$ & \multirow[t]{2}{*}{ Core 43} & Solid composite & $<1.8$ & $<1.8$ & $<1.8$ \\
\hline 2176 & & Solid composite & $<1.82$ & $<1.82$ & $<1.82$ \\
\hline 2177 & \multirow[t]{2}{*}{ Core $4 \overline{4}$} & Solid composite & $<\overline{1.83}$ & $<1.84$ & $<1.84$ \\
\hline 2178 & & Solid composite & $<1.83$ & $<1.83$ & $<1.83$ \\
\hline \multicolumn{3}{|c|}{ 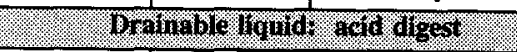 } & $16 \%$ & 486 & $\% 8$ \\
\hline 2247 & $42: 1$ & Drainable liquid & $<0.292969$ & & $<0.292969$ \\
\hline 2249 & 43: 1 & Drainable liquid & 0.12 & & 0.12 \\
\hline 2248 & 44: 1 & Drainable liquid & 0.12 & & 0.12 \\
\hline & \multicolumn{2}{|c|}{ 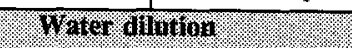 } & Ho & 486 & 184 \\
\hline 2005 & \multirow[t]{5}{*}{$44: 6$} & Water dilution & $<1.13$ & $<1.4$ & $<1.265$ \\
\hline 2006 & & Water dilution & $<1.42$ & $<1 . \overline{42}$ & $<1.42$ \\
\hline 2007 & & Water dilution & $<1.41$ & $<1.4$ & $<1.41$ \\
\hline 2008 & & Water dilution & $<1.33$ & $<1.33$ & $<1.33$ \\
\hline 2010 & & Water dilution & $<1.47$ & $<1.48$ & $<1.48^{\mathrm{QC}: \mathrm{f}}$ \\
\hline
\end{tabular}

Table B2-30. Tank 241-S-104 Analytical Results: Phosphorus (ICP). (2 sheets)

\begin{tabular}{|c|c|c|c|c|c|}
\hline Kampir & Spriplo & 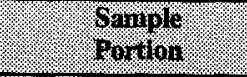 & resulin & 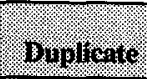 & ntan \\
\hline \multicolumn{3}{|c|}{ (6) } & $18 \%$ & 48 & $18 \%$ \\
\hline 2088 & \multirow[t]{2}{*}{ 43: 2} & Homogenized Test 1 & 16.5 & 17.2 & 16.85 \\
\hline 2089 & & Homogenized Test 2 & 19.4 & 16.6 & 18 \\
\hline 2092 & \multirow[t]{2}{*}{$43: 4$} & Homogenized Test 1 & 22.4 & 24.3 & 23.35 \\
\hline 2093 & & Homogenized Test 2 & 25.6 & 25.1 & 25.35 \\
\hline 2096 & \multirow[t]{2}{*}{$43: 6$} & Homogenized Test 1 & 13.2 & 18.8 & 16 \\
\hline 2097 & & Homogenized Test 2 & 20.8 & 26.1 & 23.45 \\
\hline 2171 & \multirow[t]{2}{*}{ Core 42} & Solid composite & 25.2 & 25 & 25.1 \\
\hline 2172 & & Solid composite & 19.2 & 20.8 & 20 \\
\hline
\end{tabular}


Table B2-30. Tank 241-S-104 Analytical Results: Phosphorus (ICP). (2 sheets)

\begin{tabular}{|c|c|c|c|c|c|}
\hline 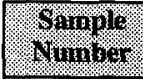 & 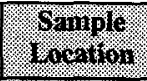 & . & 285.11 & Hoplogro & Hein \\
\hline V. & \multicolumn{2}{|c|}{ 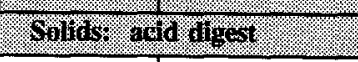 } & 408 & .88 & $1 \%$ \\
\hline 2175 & \multirow[t]{2}{*}{ Core 43} & Solid composite & 18.2 & 22.4 & 20.3 \\
\hline 2176 & & Solid composite & 13.1 & 19.3 & 16.2 \\
\hline 2177 & \multirow[t]{2}{*}{ Core 44} & Solid composite & 21.6 & 20.8 & 21.2 \\
\hline 2178 & & Solid composite & 22.8 & 25.7 & 24.25 \\
\hline & \multicolumn{2}{|c|}{ Golnst Mus } & 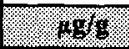 & $.1 \%$ & 1804 \\
\hline 2171 & \multirow[t]{2}{*}{ Core 42} & Solid composite & 147 & 73.6 & 110.3 \\
\hline 2172 & & Solid composite & 119 & 87.2 & 103.1 \\
\hline 2175 & \multirow[t]{2}{*}{ Core 43} & Solid composite & 102 & 56.5 & 79.25 \\
\hline 2176 & & Solid composite & 74.1 & 115 & 94.55 \\
\hline 2177 & \multirow[t]{2}{*}{ Core 44} & Solid composite & 61.4 & 109 & 85.2 \\
\hline 2178 & & Solid composite & 74.5 & 97.6 & 86.05 \\
\hline & \multicolumn{2}{|c|}{ 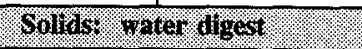 } & 1.49 & $8.96 \%$ & . \\
\hline 2171 & \multirow[t]{2}{*}{ Core 42} & Solid composite & $<10.1$ & 16 & $<13.05$ \\
\hline 2172 & & Solid composite & $<10.1$ & $<10.1$ & $<10.1$ \\
\hline 2175 & \multirow[t]{2}{*}{ Core 43} & Solid composite & 8.44 & $<8$ & $<8.22$ \\
\hline 2176 & & Solid composite & 9.67 & $<8.08$ & $<8.88$ \\
\hline 2177 & \multirow[t]{2}{*}{ Core 44} & Solid composite & $<8.14$ & $<8.16$ & $<8.15$ \\
\hline 2178 & & Solid composite & $<8.14$ & $<8.15$ & $<8.15$ \\
\hline \multicolumn{3}{|c|}{ 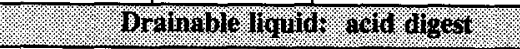 } & 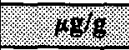 & 169 & 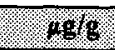 \\
\hline 2247 & 42:1 & Drainable liquid & 7.03906 & & 7.03 \\
\hline 2249 & 43: 1 & Drainable liquid & 5.95312 & & $5.95^{Q \mathrm{C}: \mathrm{f}}$ \\
\hline 2248 & 44: 1 & Drainable liquid & 5.80469 & & $5.80^{\mathrm{QC}: \mathrm{f}}$ \\
\hline 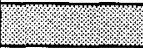 & \multicolumn{2}{|c|}{ Wus o anjton } & 48 & $1 \%$ & 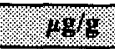 \\
\hline 2005 & \multirow[t]{6}{*}{$44: 6$} & Water dilution & $<8.01$ & $<9.9$ & $<9.0$ \\
\hline 2006 & & Water dilution & 17.2 & 24.4 & 20.8 \\
\hline 2007 & & Water dilution & 10.1 & $<9.92$ & $<10.01$ \\
\hline 2008 & & Water dilution & $<9.38$ & $<9.44$ & $<9.41$ \\
\hline \multirow[t]{2}{*}{2010} & & Water dilution & $<6.84$ & $<6.92$ & $<6.88$ \\
\hline & & Water dilution & $<8.14$ & $<8.15$ & $<8.145$ \\
\hline
\end{tabular}


HNF-SD-WM-ER-370 Rev. 1

Table B2-31. Tank 241-S-104 Analytical Results: Potassium (ICP).

\begin{tabular}{|c|c|c|c|c|c|}
\hline Shingly & 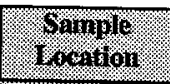 & Spomplou & resiut & Guplicite & 16 \\
\hline 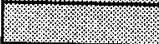 & \multicolumn{2}{|c|}{ 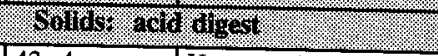 } & 48 & 1708 & $188 \mathrm{~g}$ \\
\hline 2092 & \multirow[t]{2}{*}{$43: 4$} & Homogenized Test 1 & 303 & 302 & 301 \\
\hline 2093 & & Homogenized Test 2 & 300 & 277 & 289 \\
\hline 2096 & \multirow[t]{2}{*}{ 43: 6} & Homogenized Test 1 & 200 & 216 & 208 \\
\hline 2097 & & Homogenized Test 2 & 268 & 213 & 241 \\
\hline 2171 & \multirow[t]{2}{*}{ Core 42} & Solid composite & 357 & 361 & 359 \\
\hline 2172 & & Solid composite & 355 & 353 & 354 \\
\hline 2175 & \multirow[t]{2}{*}{ Core $\overline{43}$} & Solid composite & 279 & 257 & 268 \\
\hline 2176 & & Solid composite & 267 & 274 & 271 \\
\hline 2177 & \multirow[t]{2}{*}{ Core 44} & Solid composite & 253 & 264 & 259 \\
\hline 2178 & & Solid composite & 289 & 288 & 289 \\
\hline 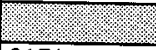 & \multicolumn{2}{|c|}{ Solidy forer Thert } & 1.96 & 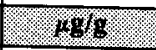 & 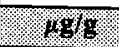 \\
\hline 2171 & \multirow[t]{2}{*}{ Core 42} & Solid composite & 336 & 351 & 344 \\
\hline 2172 & & Solid composite & 321 & 313 & 317 \\
\hline 2175 & \multirow[t]{2}{*}{ Core 43} & Solid composite & 326 & 311 & $319^{\mathrm{QC:c}}$ \\
\hline 2176 & & Solid composite & 287 & 317 & $302^{\mathrm{QC:c}}$ \\
\hline 2177 & \multirow[t]{2}{*}{ Core 44} & Solid composite & 108 & 119 & 114 \\
\hline 2178 & & Solid composite & 139 & 102 & 121 \\
\hline ?.1. & \multicolumn{2}{|c|}{ 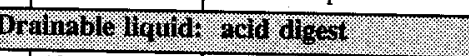 } & 986 & 10y9. & 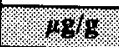 \\
\hline 2247 & $42: 1$ & Drainable liquid & 519 & & 519 \\
\hline 2249 & 43: 1 & Drainable liquid & $<\overline{641}$ & & $<641$ \\
\hline 2248 & $44: 1$ & Drainable liquid & $<740$ & & $<740$ \\
\hline ( & \multicolumn{2}{|c|}{ Water itivition } & . & 1898 & .489 \\
\hline 2005 & \multirow[t]{5}{*}{$44: 6$} & Water dilution & 242 & 223 & 233 \\
\hline 2006 & & Water dilution & 256 & 264 & 260 \\
\hline 2007 & & Water dilution & 270 & 288 & 279 \\
\hline 2008 & & Water dilution & 304 & 307 & 306 \\
\hline 2010 & & Water dilution & 177 & 181 & $179^{Q C: f}$ \\
\hline
\end{tabular}


Table B2-32. Tank 241-S-104 Analytical Results: Selenium (ICP). (2 sheets)

\begin{tabular}{|c|c|c|c|c|c|}
\hline Wimoser & \%981010 & . Sortion & Resiul & Duplacate & Yleari \\
\hline & \multicolumn{2}{|c|}{ 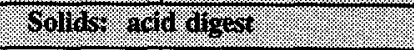 } & 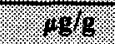 & $19 \%$ & 410 \\
\hline 2088 & \multirow[t]{2}{*}{$43: 2$} & Homogenized Test 1 & $<13.5$ & $<13.5$ & $<13.5$ \\
\hline 2089 & & Homogenized Test 2 & $<13.7$ & $<13.4$ & $<13.55$ \\
\hline 2092 & \multirow[t]{2}{*}{$43: 4$} & Homogenized Test 1 & $<12$ & $<12.7$ & $<12.35$ \\
\hline 2093 & & Homogenized Test 2 & $<12.9$ & $<13.1$ & $<13$ \\
\hline 2096 & \multirow[t]{2}{*}{$43: 6$} & Homogenized Test 1 & $\overline{25.8}$ & 31.8 & 28.8 \\
\hline 2097 & & Homogenized Test 2 & 84.7 & 58.7 & 71.7 \\
\hline 2171 & \multirow[t]{2}{*}{ Core 42} & Solid composite & $<7.95$ & $<8.03$ & $<7.99$ \\
\hline 2172 & & Solid composite & $<8.22$ & $<7.94$ & $<8.08$ \\
\hline 2175 & \multirow[t]{2}{*}{ Core 43} & Solid composite & $<12.6$ & $<12.5$ & $<12.55$ \\
\hline 2176 & & Solid composite & $<12.8$ & $<12.9$ & $<12.85$ \\
\hline 2177 & \multirow[t]{2}{*}{ Core 44} & Solid composite & 16.2 & $<12.6$ & $<14.4$ \\
\hline 2178 & & Solid composite & 91.8 & 58.3 & 75.05 \\
\hline
\end{tabular}


Table B2-32. Tank 241-S-104 Analytical Results: Selenium (ICP). (2 sheets)

\begin{tabular}{|c|c|c|c|c|c|}
\hline W1910\% & Tyanor & Symor & Revili: & Bulligate & Meani \\
\hline \multicolumn{3}{|c|}{ What $+1,10 n$} & 149 & $18+8$ & $30 \%$ \\
\hline 2171 & \multirow[t]{2}{*}{ Core 42} & Solid composite & $<41.5$ & $<41.5$ & $<41.5$ \\
\hline 2172 & & Solid composite & $<40.9$ & $<41.2$ & $<41.05$ \\
\hline 2175 & \multirow[t]{2}{*}{ Core 43} & Solid composite & $<70.1$ & $<69.7$ & $<69.9$ \\
\hline 2176 & & Solid composite & $<69.1$ & $<68.8$ & $<68.95$ \\
\hline 2177 & \multirow[t]{2}{*}{ Core 44} & Solid composite & $<64.6$ & $<65.5$ & $<65.05$ \\
\hline 2178 & & Solid composite & $<64.9$ & $<65$ & $<64.95$ \\
\hline 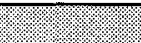 & \multicolumn{2}{|c|}{ 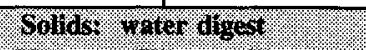 } & 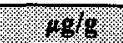 & .098 & 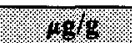 \\
\hline 2171 & \multirow[t]{2}{*}{ Core 42} & Solid composite & $<8.43$ & $<8.38$ & $<8.405$ \\
\hline 2172 & & Solid composite & $<8.43$ & $<8.47$ & $<8.45$ \\
\hline 2175 & \multirow[t]{2}{*}{ Core 43} & Solid composite & $<13.1$ & $<13.1$ & $<13.1$ \\
\hline 2176 & & Solid composite & $<13.3$ & $<13.2$ & $<13.25$ \\
\hline 2177 & \multirow[t]{2}{*}{ Core 44} & Solid composite & 26.6 & 48.3 & 37.45 \\
\hline 2178 & & Solid composite & 32.2 & 19.8 & 26 \\
\hline \multicolumn{3}{|c|}{ 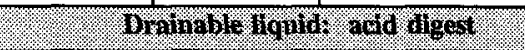 } & 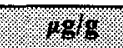 & 198 & 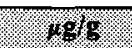 \\
\hline 2247 & 42: 1 & Drainable liquid & $<2.75$ & & $<2.75$ \\
\hline 2249 & 43: 1 & Drainable liquid & $<1.10$ & & $<1.10^{\mathrm{QC}: \mathrm{f}}$ \\
\hline 2248 & 44: 1 & Drainable liquid & $<1.10$ & & $<1.10^{\mathrm{oc}: f}$ \\
\hline \multicolumn{3}{|c|}{ Her $1110 \%$} & 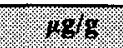 & 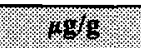 & 198 \\
\hline 2005 & \multirow[t]{5}{*}{$44: 6$} & Water dilution & 739 & 696 & 718 \\
\hline 2006 & & Water dilution & 925 & 937 & 931 \\
\hline 2007 & & Water dilution & $<8.37$ & $<8.32$ & $<8.34$ \\
\hline 2008 & & Water dilution & $<7.87$ & $<7.91$ & $<7.89^{\mathrm{QC}: \mathrm{f}}$ \\
\hline 2010 & & Water dilution & 90.7 & 109 & 99.85 \\
\hline
\end{tabular}


Table B2-33. Tank 241-S-104 Analytical Results: Selenium (Atomic Absorption).

\begin{tabular}{|c|c|c|c|c|c|}
\hline $\begin{array}{l}\text { Sample: } \\
\text { Numbler }\end{array}$ & $\begin{array}{l}\text { Simplo } \\
\text { Eecation }\end{array}$ & $\begin{array}{l}\text { Sinnole } \\
\text { Portion. }\end{array}$ & Mesull: & Byolicare. & Mean \\
\hline 2 & \multicolumn{2}{|c|}{ 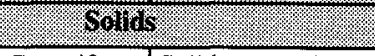 } & 2.896 & 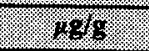 & .2868 \\
\hline 2171 & \multirow[t]{2}{*}{ Core 42} & Solid composite & $<2.5 \mathrm{E}-04$ & $<0.25$ & $<0.13$ \\
\hline 2172 & & Solid composite & $<0.25$ & $<0.25$ & $<0 . \overline{25}$ \\
\hline 2175 & \multirow[t]{2}{*}{ Core 43} & Solid composite & $<0.25$ & $<0.25$ & $<0.25$ \\
\hline 2176 & & Solid composite & $<0.25$ & $<0.25$ & $<0.25$ \\
\hline 2177 & \multirow[t]{2}{*}{ Core 44} & Solid composite & $<0.25$ & $<0.25$ & $<0.25$ \\
\hline 2178 & & Solid composite & 0.30 & $<0.25$ & $<0.27$ \\
\hline & \multicolumn{2}{|c|}{ Sollols. } & tefriol & 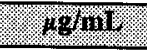 & 196rin \\
\hline 2231 & Core 44 & Solid composite & 1.34 & & 1.34 \\
\hline
\end{tabular}

Table B2-34. Tank 241-S-104 Analytical Results: Silicon (ICP). (2 sheets)

\begin{tabular}{|c|c|c|c|c|c|}
\hline $\begin{array}{l}\text { Samplo. } \\
\text { Number }\end{array}$ & $\begin{array}{l}\text { Somple } \\
\text { Eocritions }\end{array}$ & $\begin{array}{l}\text { Sample } \\
\text { Sartion }\end{array}$ & fresulti: & Miplising & Mreng \\
\hline ?: & \multicolumn{2}{|c|}{ Sollos: ang angest } & 6.86 & 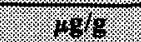 & 4098 \\
\hline 2088 & \multirow[t]{2}{*}{ 43: 2} & Homogenized Test 1 & 212 & 211 & $211.5^{\mathrm{QCC} ; \mathrm{c}}$ \\
\hline 2089 & & Homogenized Test 2 & 206 & 159 & $182.5^{\mathrm{OC} ; \mathrm{e}}$ \\
\hline 2092 & \multirow[t]{2}{*}{ 43: 4} & Homogenized Test 1 & 287 & 80.6 & 183.8 \\
\hline 2093 & & Homogenized Test 2 & $<2.26$ & 107 & $<54.63$ \\
\hline 2096 & \multirow[t]{2}{*}{$43: 6$} & Homogenized Test 1 & 103 & 61.1 & 82.05 \\
\hline 2097 & & Homogenized Test 2 & 199 & 193 & 196 \\
\hline 2171 & \multirow[t]{2}{*}{ Core 42} & Solid composite & 160 & 175 & 167.5 \\
\hline 2172 & & Solid composite & 165 & 145 & 155 \\
\hline 2175 & \multirow[t]{2}{*}{ Core 43} & Solid composite & 167 & 189 & 178 \\
\hline 2176 & & Solid composite & 202 & 196 & 199 \\
\hline 2177 & \multirow[t]{2}{*}{ Core 44} & Solid composite & 301 & 209 & 255 \\
\hline 2178 & & Solid composite & 205 & 187 & 196 \\
\hline
\end{tabular}


HNF-SD-WM-ER-370 Rev. 1

Table B2-34. Tank 241-S-104 Analytical Results: Silicon (ICP). (2 sheets)

\begin{tabular}{|c|c|c|c|c|c|}
\hline Ooningor & 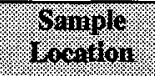 & . & iesply. & Byplinive & Mearu \\
\hline \multicolumn{3}{|c|}{ 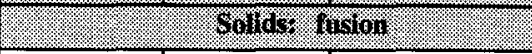 } & 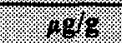 & 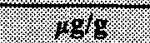 & Herk \\
\hline 2171 & \multirow[t]{2}{*}{ Core 42} & Solid composite & 1,030 & 1,040 & 1,035 \\
\hline 2172 & & Solid composite & 1,180 & 1,090 & 1,135 \\
\hline 2175 & \multirow[t]{2}{*}{ Core 43} & Solid composite & 1,230 & 1,130 & 1,180 \\
\hline 2176 & & Solid composite & 2,310 & 947 & 1,630 \\
\hline 2177 & \multirow[t]{2}{*}{ Core 44} & Solid composite & 1,440 & 1,400 & 1,420 \\
\hline 2178 & & Solid composite & 1,570 & 1,550 & 1,560 \\
\hline & \multicolumn{2}{|c|}{ 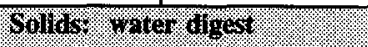 } & $198 \%$ & 48 & 486 \\
\hline 2171 & \multirow[t]{2}{*}{ Core 42} & Solid composite & 44.6 & 146 & 95.3 \\
\hline 2172 & & Solid composite & 55.8 & $\overline{43.4}$ & 49.6 \\
\hline 2175 & \multirow[t]{2}{*}{ Core 43} & Solid composite & 46.6 & 21.6 & 34.1 \\
\hline 2176 & & Solid composite & 27.7 & 29.6 & 28.65 \\
\hline 2177 & \multirow[t]{2}{*}{ Core 44} & Solid composite & 15.2 & 18.1 & 16.65 \\
\hline 2178 & & Solid composite & 16.7 & 12.7 & 14.7 \\
\hline \multicolumn{3}{|c|}{ 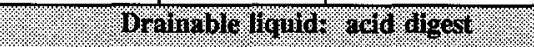 } & 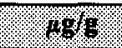 & 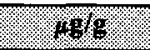 & W \\
\hline 2247 & 42: 1 & Drainable liquid & 41 & & $41^{\text {QC: }}$ \\
\hline 2249 & 43: 1 & Drainable liquid & $<11$ & & $<11$ \\
\hline 2248 & 44: 1 & Drainable liquid & 7.45 & & 7.45 \\
\hline \multicolumn{3}{|c|}{ 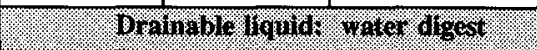 } & 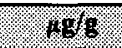 & (610 & . \\
\hline 2005 & \multirow[t]{6}{*}{ 44: 1} & Drainable liquid & $<3.48$ & $<4.3$ & $<3.89^{\text {oC:f }}$ \\
\hline 2006 & & Drainable liquid & 32 & 20.6 & $26.3^{\overline{Q C: f}}$ \\
\hline 2007 & & Drainable liquid & 23.3 & 24.8 & $24.05^{\mathrm{QC}: \mathrm{f}}$ \\
\hline 2008 & & Drainable liquid & 18.3 & $<4.1$ & $<11.2^{\mathrm{QC:f}}$ \\
\hline \multirow[t]{2}{*}{2010} & & Drainable liquid & 10.5 & 8.41 & $9.46^{\text {QC:f }}$ \\
\hline & & Drainable liquid & 10.7 & 16.6 & $13.65^{\mathrm{QC}: \mathrm{f}}$ \\
\hline
\end{tabular}


Table B2-35. Tank 241-S-104 Analytical Results: Silver (ICP). (2 sheets)

\begin{tabular}{|c|c|c|c|c|c|}
\hline 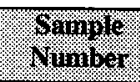 & 6omplo & 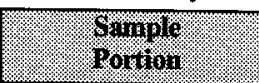 & resill & Buplicino & Menir \\
\hline & \multicolumn{2}{|c|}{ 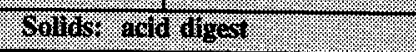 } & 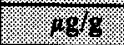 & 19 & 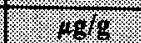 \\
\hline 2088 & \multirow[t]{2}{*}{ 43: 2} & Homogenized Test 1 & $<0.86$ & $<0.86$ & $<0.86$ \\
\hline 2089 & & Homogenized Test 2 & $<0.88$ & $<0.86$ & $<0.87$ \\
\hline 2092 & \multirow[t]{2}{*}{$43: 4$} & Homogenized Test 1 & $<0.92$ & $<0.97$ & $<0.94$ \\
\hline 2093 & & Homogenized Test 2 & $<0.98$ & $<1$ & $<0.99$ \\
\hline 2096 & \multirow[t]{2}{*}{$43: 6$} & Homogenized Test 1 & $<0.99$ & $<0.94$ & $<0.97$ \\
\hline 2097 & & Homogenized Test 2 & $<1.49$ & $<1.29$ & $<1.39$ \\
\hline 2171 & \multirow[t]{2}{*}{ Core 42} & Solid composite & $<0.96$ & $<0.97$ & $<0.96$ \\
\hline 2172 & & Solid composite & $<0.99$ & $<0.96$ & $<0.97$ \\
\hline 2175 & \multirow[t]{2}{*}{ Core 43} & Solid composite & $<0.97$ & $<0.95$ & $<0.96$ \\
\hline 2176 & & Solid composite & $<0.98$ & $<0.97$ & $<0.98$ \\
\hline 2177 & \multirow[t]{2}{*}{ Core 44} & Solid composite & $<0.98$ & $<0.96$ & $<0.97$ \\
\hline 2178 & & Solid composite & $<0.97$ & $<\overline{0.95}$ & $<0.96$ \\
\hline & \multicolumn{2}{|c|}{ Sollds. Huror } & (1.969. & 8.48 & r. \\
\hline 2171 & \multirow[t]{2}{*}{ Core 42} & Solid composite & $<5$ & $<5$ & $<5$ \\
\hline 2172 & & Solid composite & $<4.93$ & $<4.96$ & $<4.95$ \\
\hline 2175 & \multirow[t]{2}{*}{ Core 43} & Solid composite & $<4.47$ & $<4.45$ & $<4.46$ \\
\hline 2176 & & Solid composite & $<\overline{4.41}$ & $<4.39$ & $<4.4$ \\
\hline 2177 & \multirow[t]{2}{*}{ Core 44} & Solid composite & $<4.93$ & $<5$ & $<4.97$ \\
\hline 2178 & & Solid composite & $<4.95$ & $<4.96$ & $<4.96$ \\
\hline & \multicolumn{2}{|c|}{ Solvert water digert } & $19 / 8$ & $\% 98$ & 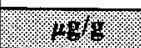 \\
\hline 2171 & \multirow[t]{2}{*}{ Core 42} & Solid composite & 1.43 & 2.03 & 1.73 \\
\hline 2172 & & Solid composite & $<1.02$ & $<1.02$ & $<1.02$ \\
\hline 2175 & \multirow[t]{2}{*}{ Core 43} & Solid composite & 1.42 & $<1$ & $<1.21$ \\
\hline 2176 & & Solid composite & $<1.01$ & $<1.01$ & $<1.01$ \\
\hline 2177 & \multirow[t]{2}{*}{ Core 44} & Solid composite & $<1.02$ & $<1.02$ & $<1.02$ \\
\hline 2178 & & Solid composite & $<1.02$ & $<1.02$ & $<1.02$ \\
\hline \multicolumn{3}{|c|}{ 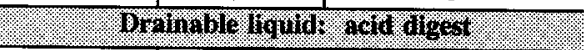 } & $28 \%$ & 68 & 1.18 \\
\hline 2247 & $42: 1$ & Drainable liquid & $<0.18$ & & $<0.18^{\mathrm{QC}: \mathrm{f}}$ \\
\hline 2249 & 43: 1 & Drainable liquid & 0.0703 & & $0.070^{\mathrm{QC}: \mathrm{f}}$ \\
\hline 2248 & $44: 1$ & Drainable liquid & 0.0703 & & $0.070^{\mathrm{QC}: \mathrm{F}}$ \\
\hline
\end{tabular}


Table B2-35. Tank 241-S-104 Analytical Results: Silver (ICP). (2 sheets)

\begin{tabular}{|c|c|c|c|c|c|}
\hline 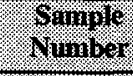 & (5) & oromp & (3) & Buplegite & Nom \\
\hline \multicolumn{3}{|c|}{ 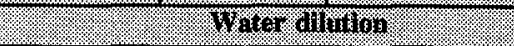 } & 48 & 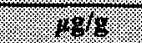 & 896 \\
\hline 2005 & \multirow[t]{5}{*}{$44: 6$} & Water dilution & $<0.81$ & $<1$ & $<0.90$ \\
\hline 2006 & & Water dilution & $<1.01$ & $<1.01$ & $<1.01$ \\
\hline 2007 & & Water dilution & $<1.01$ & $<1$ & $<1.00^{\mathrm{QC}: \mathrm{f}}$ \\
\hline 2008 & & Water dilution & $<0.95$ & $<0.95$ & $<0.95$ \\
\hline 2010 & & Water dilution & $<0.88$ & $<0.89$ & $<0.88^{\mathrm{QC} . \mathrm{f}}$ \\
\hline
\end{tabular}

Table B2-36. Tank 241-S-104 Analytical Results: Sodium (ICP). (2 sheets)

\begin{tabular}{|c|c|c|c|c|c|}
\hline Wanger & S.mol & 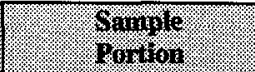 & Irenillo & Ouplosicis & Wora \\
\hline & \multicolumn{2}{|c|}{ W10\%, } & 46 & 148 & $18 \times \mathrm{s}$ \\
\hline 2088 & \multirow[t]{2}{*}{ 43: 2} & Homogenized Test 1 & $1.22 \mathrm{E}+05$ & $1.18 \mathrm{E}+05$ & $1.20 \mathrm{E}+05^{\mathrm{QC}: \mathrm{c}}$ \\
\hline 2089 & & Homogenized Test 2 & $1.19 \mathrm{E}+05$ & $1.17 \mathrm{E}+05$ & $1.18 \mathrm{E}+05^{\mathrm{QC}: c}$ \\
\hline 2092 & \multirow[t]{2}{*}{$43: \overline{4}$} & Homogenized Test 1 & $1.16 \mathrm{E}+05$ & $1.18 \mathrm{E}+05$ & $1.17 \mathrm{E}+05^{\overline{\mathrm{QC}: \mathrm{e}}}$ \\
\hline 2093 & & Homogenized Test 2 & $1.11 \mathrm{E}+05$ & $1.06 \mathrm{E}+05$ & $1.08 \mathrm{E}+05^{\mathrm{QC}: \mathrm{c}}$ \\
\hline 2096 & \multirow[t]{2}{*}{$43: 6$} & Homogenized Test 1 & $1.41 \mathrm{E}+05$ & $1.29 \mathrm{E}+05$ & $1.35 \mathrm{E}+05^{\mathrm{QC}: \mathrm{d}}$ \\
\hline 2097 & & Homogenized Test 2 & $1.29 \mathrm{E}+05$ & $1.45 \mathrm{E}+05$ & $1.37 \mathrm{E}+05^{\mathrm{QC}: \mathrm{d}}$ \\
\hline 2171 & \multirow[t]{2}{*}{ Core 42} & Solid composite & $1.32 \mathrm{E}+05$ & $1.30 \mathrm{E}+05$ & $1.31 \mathrm{E}+05^{\mathrm{QC}: \mathrm{c}}$ \\
\hline 2172 & & Solid composite & $1.17 \mathrm{E}+05$ & $1.21 \mathrm{E}+05$ & $1.19 \mathrm{E}+05^{\mathrm{QC}: c}$ \\
\hline 2175 & \multirow[t]{2}{*}{ Core 43} & Solid composite & $1.18 \mathrm{E}+05$ & $1.16 \mathrm{E}+05$ & $1.17 \mathrm{E}+05$ \\
\hline 2176 & & Solid composite & $1.15 \mathrm{E}+05$ & $1.20 \mathrm{E}+05$ & $1.17 \mathrm{E}+05$ \\
\hline 2177 & \multirow[t]{2}{*}{ Core 44} & Solid composite & $1.14 \mathrm{E}+05$ & $1.22 \mathrm{E}+05$ & $1.18 \mathrm{E}+05$ \\
\hline 2178 & & Solid composite & $1.20 \mathrm{E}+05$ & $1.23 \mathrm{E}+05$ & $1.21 \mathrm{E}+05^{\mathrm{QC}: \mathrm{d}}$ \\
\hline & \multicolumn{2}{|c|}{ oblot yon } & 186 & 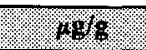 & 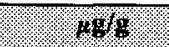 \\
\hline 2171 & \multirow[t]{2}{*}{ Core 42} & Solid composite & $1.24 \mathrm{E}+05$ & $1.25 \mathrm{E}+05$ & $1.24 \mathrm{E}+05^{\mathrm{QC}: \mathrm{c}}$ \\
\hline 2172 & & Solid composite & $1.16 \mathrm{E}+05$ & $1.19 \mathrm{E}+05$ & $1.17 \mathrm{E}+05^{\mathrm{QC}: \mathrm{c}}$ \\
\hline 2175 & \multirow[t]{2}{*}{ Core 43} & Solid composite & $1.19 \mathrm{E}+05$ & $1.20 \mathrm{E}+05$ & $1.19 \mathrm{E}+05$ \\
\hline 2176 & & Solid composite & $1.16 \mathrm{E}+05$ & $1.19 \mathrm{E}+05$ & $1.17 \mathrm{E}+05$ \\
\hline 2177 & \multirow[t]{2}{*}{ Core 44} & Solid composite & $1.14 \mathrm{E}+05$ & $1.13 \mathrm{E}+05$ & $1.13 \mathrm{E}+05$ \\
\hline 2178 & & Solid composite & $1.15 \mathrm{E}+05$ & $1.19 \mathrm{E}+05$ & $1.17 \mathrm{E}+05$ \\
\hline
\end{tabular}


Table B2-36. Tank 241-S-104 Analytical Results: Sodium (ICP). (2 sheets)

\begin{tabular}{|c|c|c|c|c|c|}
\hline 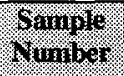 & 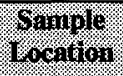 & (6) & iresuit & Ouplolisate. & ycan \\
\hline & \multicolumn{2}{|c|}{ 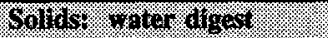 } & 48 & 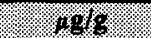 & 60 \\
\hline 2171 & \multirow[t]{2}{*}{ Core 42} & Solid composite & $1.16 \mathrm{E}+05$ & $1.20 \mathrm{E}+05$ & $1.18 \mathrm{E}+05$ \\
\hline 2172 & & Solid composite & $1.18 \mathrm{E}+05$ & $1.24 \mathrm{E}+05$ & $1.21 \mathrm{E}+05$ \\
\hline 2175 & \multirow[t]{2}{*}{ Core 43} & Solid composite & $1.18 \mathrm{E}+05$ & $1.20 \mathrm{E}+05$ & $1.19 \mathrm{E}+05$ \\
\hline 2176 & & Solid composite & $1.21 \mathrm{E}+05$ & $1.17 \mathrm{E}+05$ & $1.19 \mathrm{E}+05$ \\
\hline 2177 & \multirow[t]{2}{*}{ Core 44} & Solid composite & 28,000 & 45,500 & 36,750 \\
\hline 2178 & & Solid composite & 44,300 & 33,300 & 38,800 \\
\hline \multicolumn{3}{|c|}{ 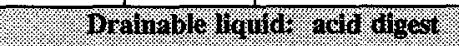 } & 1018 & $0.8 \%$ & $18 \%$ \% \\
\hline 2247 & 42: 1 & Drainable liquid & $1.61 \mathrm{E}+05$ & & $1.61 \mathrm{E}+05$ \\
\hline 2249 & 43: 1 & Drainable liquid & $1.51 \mathrm{E}+05$ & & $1.51 \mathrm{E}+05$ \\
\hline 2248 & 44: 1 & Drainable liquid & $1.52 \mathrm{E}+05$ & & $1.52 \mathrm{E}+05$ \\
\hline \multicolumn{3}{|c|}{ Watc) difutron } & 48 & 1868 & $1,88 \%$ \\
\hline 2005 & \multirow[t]{4}{*}{$44: 6$} & Water dilution & $1.150 \mathrm{E}+05$ & $1.280 \mathrm{E}+05$ & $1.22 \mathrm{E}+05$ \\
\hline 2006 & & Water dilution & $1.160 \mathrm{E}+05$ & $1.140 \mathrm{E}+05$ & $1.150 \mathrm{E}+05$ \\
\hline 2007 & & Water dilution & $1.380 \mathrm{E}+05$ & $1.370 \mathrm{E}+05$ & $1.38 \mathrm{E}+05$ \\
\hline 2010 & & Water dilution & 78,400 & 61,000 & $69,700^{\mathrm{QC:c}}$ \\
\hline
\end{tabular}

Table B2-37. Tank 241-S-104 Analytical Results: Strontium (ICP). (2 sheets)

\begin{tabular}{|c|c|c|c|c|c|}
\hline 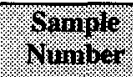 & 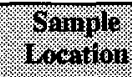 & Whole & nic-in & Yuplogita. & Mara \\
\hline \multicolumn{3}{|c|}{ 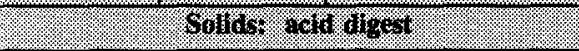 } & 4.98. & $48 \%$ & $48 \%$ \\
\hline 2088 & \multirow[t]{2}{*}{$43: 2$} & Homogenized Test 1 & 173 & 183 & 178 \\
\hline 2089 & & Homogenized Test 2 & 183 & 185 & 184 \\
\hline 2092 & \multirow[t]{2}{*}{$43: 4$} & Homogenized Test 1 & 405 & 423 & 414 \\
\hline 2093 & & Homogenized Test 2 & 434 & 391 & 412.5 \\
\hline 2096 & \multirow[t]{2}{*}{$43: 6$} & Homogenized Test 1 & 359 & 386 & 372.5 \\
\hline 2097 & & Homogenized Test 2 & 455 & 406 & 430.5 \\
\hline 2171 & \multirow[t]{2}{*}{ Core 42} & Solid composite & 338 & 296 & 317 \\
\hline 2172 & & Solid composite & 368 & 358 & 363 \\
\hline
\end{tabular}


Table B2-37. Tank 241-S-104 Analytical Results: Strontium (ICP). (2 sheets)

\begin{tabular}{|c|c|c|c|c|c|}
\hline $\begin{array}{l}\text { Sample: } \\
\text { Number. }\end{array}$ & $\begin{array}{l}\text { Sarnple } \\
\text { Yesalion }\end{array}$ & 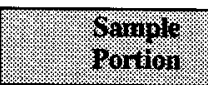 & 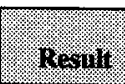 & Buplierie. & Meari: \\
\hline 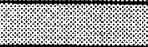 & \multicolumn{2}{|c|}{ 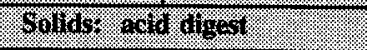 } & 198\% & 6858: & 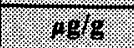 \\
\hline 2175 & \multirow[t]{2}{*}{ Core 43} & Solid composite & 327 & 328 & 327.5 \\
\hline 2176 & & Solid composite & 345 & 350 & 347.5 \\
\hline 2177 & \multirow[t]{2}{*}{ Core 44} & Solid composite & 321 & 329 & 325 \\
\hline 2178 & & Solid composite & 283 & 264 & 273.5 \\
\hline 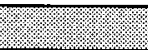 & \multicolumn{2}{|c|}{ Sollats Thion } & 1089 & $108 \mathrm{~g}$ & 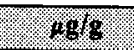 \\
\hline 2171 & \multirow[t]{2}{*}{ Core 42} & Solid composite & 416 & 401 & 408.5 \\
\hline 2172 & & Solid composite & 434 & 399 & 416.5 \\
\hline 2175 & \multirow[t]{2}{*}{ Core 43} & Solid composite & 415 & 440 & 427.5 \\
\hline 2176 & & Solid composite & 503 & 474 & 488.5 \\
\hline 2177 & \multirow[t]{2}{*}{ Core 44} & Solid composite & 371 & 488 & 429.5 \\
\hline 2178 & & Solid composite & 372 & 373 & 372.5 \\
\hline & \multicolumn{2}{|c|}{ Solids: winer itigest } & $100 \%$ & $.10 \mathrm{E}$ & . 1858 \\
\hline 2171 & \multirow[t]{2}{*}{ Core 42} & Solid composite & $<0.406$ & 1.08 & $<0.743$ \\
\hline 2172 & & Solid composite & $<0.406$ & $<0.408$ & $<0.407$ \\
\hline 2175 & \multirow[t]{2}{*}{ Core 43} & Solid composite & 0.777 & 0.927 & 0.852 \\
\hline 2176 & & Solid composite & 0.695 & 0.833 & 0.764 \\
\hline 2177 & \multirow[t]{2}{*}{ Core 44} & Solid composite & 0.688 & $<0.612$ & $<0.65$ \\
\hline 2178 & & Solid composite & 0.824 & $<0.611$ & $<0.7175$ \\
\hline 1. & \multicolumn{2}{|c|}{ Braingble liguide fert digest } & $40 / 2$ & . $19 \mathrm{~g}$ & 1.8\% \\
\hline 2247 & $42: 1$ & Drainable liquid & $<0.059$ & & $<0.059$ \\
\hline 2249 & 43: 1 & Drainable liquid & 0.023 & & $0.023^{\mathrm{QC}: \mathrm{f}}$ \\
\hline 2248 & $44: 1$ & Drainable liquid & 0.037 & & $0.037^{\mathrm{QC:f}}$ \\
\hline & \multicolumn{2}{|c|}{ Wigureritinon } & 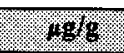 & 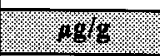 & $148 / \mathrm{g}$ \\
\hline 2005 & \multirow[t]{5}{*}{$44: 6$} & Water dilution & $<0.32$ & $<0.4$ & $<0.362$ \\
\hline 2006 & & Water dilution & 2.11 & 0.53 & 1.32 \\
\hline 2007 & & Water dilution & 4.47 & 0.68 & 2.58 \\
\hline 2008 & & Water dilution & $<0.38$ & 0.61 & $<0.50$ \\
\hline 2010 & & Water dilution & 0.73 & 0.74 & $0.74^{\mathrm{QC}: \mathrm{f}}$ \\
\hline
\end{tabular}


Table B2-38. Tank 241-S-104 Analytical Results: Sulfur (ICP). (2 sheets)

\begin{tabular}{|c|c|c|c|c|c|}
\hline Simile: & $\begin{array}{l}\text { Sumples } \\
\text { 1Ercobion }\end{array}$ & 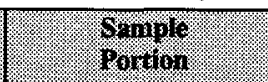 & iresing & (0)isicate. & 18 equ \\
\hline & \multicolumn{2}{|c|}{ 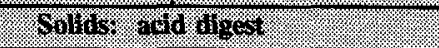 } & $48 / 8$ & $1 \% 8 \%$ & 4.18 \\
\hline 2088 & \multirow[t]{2}{*}{ 43: 2} & Homogenized Test 1 & 324 & 347 & 335.5 \\
\hline 2089 & & Homogenized Test 2 & 347 & 338 & 342.5 \\
\hline 2092 & \multirow[t]{2}{*}{$43: 4$} & Homogenized Test 1 & 366 & 366 & $\overline{366}$ \\
\hline 2093 & & Homogenized Test 2 & 382 & 394 & 388 \\
\hline 2096 & \multirow[t]{2}{*}{$43: 6$} & Homogenized Test 1 & 400 & 437 & 418.5 \\
\hline 2097 & & Homogenized Test 2 & $\overline{476}$ & 380 & 428 \\
\hline 2171 & \multirow[t]{2}{*}{ Core 42} & Solid composite & 418 & 445 & 431.5 \\
\hline 2172 & & Solid composite & 415 & 404 & 409.5 \\
\hline 2175 & \multirow[t]{2}{*}{ Core 43} & Solid composite & 435 & 389 & 412 \\
\hline 2176 & & Solid composite & 414 & 388 & 401 \\
\hline 2177 & \multirow[t]{2}{*}{ Core 44} & Solid composite & 350 & 347 & 348.5 \\
\hline 2178 & & Solid composite & 367 & 359 & 363 \\
\hline & \multirow{3}{*}{$\begin{array}{l}\text { Soldos } \\
\text { Core } 42\end{array}$} & finsion : & $18 \%$ & 1868 & 1.968 \\
\hline 2171 & & Solid composite & 464 & 467 & 465.5 \\
\hline 2172 & & Solid composite & 473 & 462 & 467.5 \\
\hline 2175 & \multirow[t]{2}{*}{ Core 43} & Solid composite & 463 & 482 & 472.5 \\
\hline 2176 & & Solid composite & 449 & 430 & 439.5 \\
\hline 2177 & \multirow[t]{2}{*}{ Core 44} & Solid composite & 439 & 459 & $449^{\mathrm{OC:c}}$ \\
\hline 2178 & & Solid composite & 615 & 461 & $538^{\mathrm{QC:c}}$ \\
\hline s, & \multicolumn{2}{|c|}{ Solldes: viter digest } & $4 \mathrm{~g} / \mathrm{s}$ & $4 \mathrm{E} / 8$ & 40 \\
\hline 2171 & \multirow[t]{2}{*}{ Core 42} & Solid composite & 478 & 470 & 474 \\
\hline 2172 & & Solid composite & 467 & 431 & 449 \\
\hline 2175 & \multirow[t]{2}{*}{ Core 43} & Solid composite & 445 & 455 & $450^{\mathrm{QC:c}}$ \\
\hline 2176 & & Solid composite & 459 & 480 & $469.5^{\mathrm{QC}: c}$ \\
\hline 2177 & \multirow[t]{2}{*}{ Core 44} & Solid composite & 74.9 & 123 & 98.95 \\
\hline 2178 & & Solid composite & 121 & 77.1 & 99.05 \\
\hline & \multicolumn{2}{|c|}{ 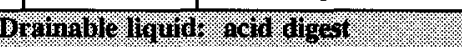 } & 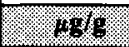 & $=1096$ & 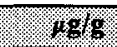 \\
\hline 2247 & 42: 1 & Drainable liquid & 424 & & 424 \\
\hline 2249 & 43: 1 & Drainable liquid & 383 & & 383 \\
\hline 2248 & $44: 1$ & Drainable liquid & 423 & & 423 \\
\hline
\end{tabular}


Table B2-38. Tank 241-S-104 Analytical Results: Sulfur (ICP). (2 sheets)

\begin{tabular}{|c|c|c|c|c|c|}
\hline 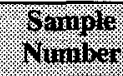 & 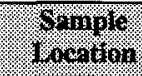 & ( ogmole & orim & Toblowate & Hean \\
\hline 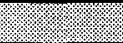 & \multicolumn{2}{|c|}{ 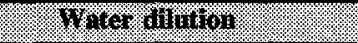 } & 4869 & 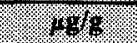 & 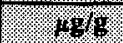 \\
\hline 2005 & \multirow[t]{5}{*}{$44: 6$} & Water dilution & 487 & 462 & 474.5 \\
\hline 2006 & & Water dilution & 494 & 525 & 509.5 \\
\hline 2007 & & Water dilution & 469 & 480 & 474.5 \\
\hline 2008 & & Water dilution & 488 & 471 & 479.5 \\
\hline 2010 & & Water dilution & 191 & 199 & 195 \\
\hline
\end{tabular}

Table B2-39. Tank 241-S-104 Analytical Results: Tin (ICP). (2 sheets)

\begin{tabular}{|c|c|c|c|c|c|}
\hline 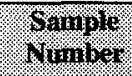 & 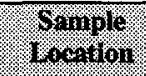 & 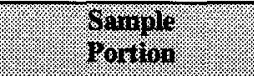 & iresint & 8910110.10 & Hena \\
\hline & \multicolumn{2}{|c|}{ 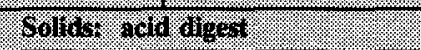 } & 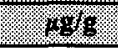 & 48 & 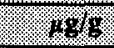 \\
\hline 2088 & \multirow[t]{2}{*}{ 43: 2} & Homogenized Test 1 & 4.95 & 2.65 & 3.8 \\
\hline 2089 & & Homogenized Test 2 & 4.18 & 3.68 & 3.93 \\
\hline 2092 & \multirow[t]{2}{*}{$43: 4$} & Homogenized Test 1 & $<1.47$ & $<1.55$ & $<1.51$ \\
\hline 2093 & & Homogenized Test 2 & $<1.57$ & $<1.6$ & $<1.585$ \\
\hline 2096 & \multirow[t]{2}{*}{$43: 6$} & Homogenized Test 1 & $<2.28$ & $<2.17$ & $<2.225$ \\
\hline 2097 & & Homogenized Test 2 & $<2.38$ & $<2.06$ & $<2.22$ \\
\hline 2171 & \multirow[t]{2}{*}{ Core 42} & Solid composite & $<2.2$ & $<2.22$ & $<2.21$ \\
\hline 2172 & & Solid composite & $<2.28$ & $<2.2$ & $<2.24$ \\
\hline 2175 & \multirow[t]{2}{*}{ Core 43} & Solid composite & $<1.54$ & $<1.53$ & $<1.535$ \\
\hline 2176 & & Solid composite & $<1.57$ & 1.84 & $<1.705$ \\
\hline 2177 & \multirow[t]{2}{*}{ Core 44} & Solid composite & $<1.57$ & $<1.54$ & $<1.555$ \\
\hline 2178 & & Solid composite & 1.77 & $<1.52$ & $<1.645$ \\
\hline \multicolumn{3}{|c|}{601165,6910} & 48 & 48 & 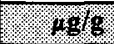 \\
\hline 2171 & \multirow[t]{2}{*}{ Core 42} & Solid composite & $<11.5$ & $<11.5$ & $<11.5$ \\
\hline 2172 & & Solid composite & $<11.3$ & $<11.4$ & $<11.35$ \\
\hline 2175 & \multirow[t]{2}{*}{ Core 43} & Solid composite & $<8.95$ & $<8.89$ & $<8.92$ \\
\hline 2176 & & Solid composite & $<8.82$ & $<8.79$ & $<8.805$ \\
\hline 2177 & \multirow[t]{2}{*}{ Core 44} & Solid composite & $<7.89$ & $<8$ & $<7.945$ \\
\hline 2178 & & Solid composite & $<7.92$ & $<7.94$ & $<7.93$ \\
\hline
\end{tabular}


Table B2-39. Tank 241-S-104 Analytical Results: Tin (ICP). (2 sheets)

\begin{tabular}{|c|c|c|c|c|c|}
\hline Mannor & 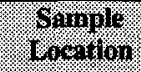 & anole & rysur & Byolscase & 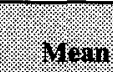 \\
\hline & \multicolumn{2}{|c|}{ 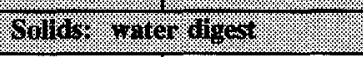 } & 48 & 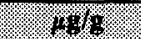 & $48 \%$ \\
\hline 2171 & \multirow[t]{2}{*}{ Core 42} & Solid composite & 2.51 & $<2.32$ & $<2.415$ \\
\hline 2172 & & Solid composite & $<2.34$ & $<2.35$ & $<2.345$ \\
\hline 2175 & \multirow[t]{2}{*}{ Core 43} & Solid composite & 3.98 & 2.27 & 3.125 \\
\hline 2176 & & Solid composite & 2.52 & 3.17 & 2.845 \\
\hline 2177 & \multirow[t]{2}{*}{ Core 44} & Solid composite & $<1.63$ & $<1.63$ & $<1.63$ \\
\hline 2178 & & Solid composite & $<1.63$ & $<1.63$ & $<1.63$ \\
\hline \multicolumn{3}{|c|}{ 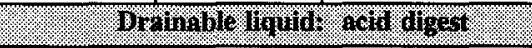 } & 1018 & 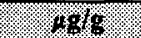 & 40 \\
\hline 2247 & 42: 1 & Drainable liquid & 2.57 & & 2.57 \\
\hline 2249 & 43: 1 & Drainable liquid & $<2.23$ & & $<2.23$ \\
\hline 2248 & 44: 1 & Drainable liquid & 2.63 & & 2.63 \\
\hline & \multicolumn{2}{|c|}{ Water ofivinon } & 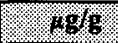 & 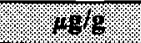 & $18.8 / 8$ \\
\hline 2005 & \multirow[t]{5}{*}{$44: 6$} & Water dilution & $<1.86$ & $<2.3$ & $<2.08$ \\
\hline 2006 & & Water dilution & $<2.33$ & $<2.33$ & $<2.33$ \\
\hline 2007 & & Water dilution & 2.6 & $<2.3$ & $<2.45$ \\
\hline 2008 & & Water dilution & $<2.18$ & $<2.19$ & $<2.19$ \\
\hline 2010 & & Water dilution & $<1.76$ & $<1.78$ & $<1.77$ \\
\hline
\end{tabular}

Table B2-40. Tank 241-S-104 Analytical Results: Titanium (ICP). (3 sheets)

\begin{tabular}{|c|c|c|c|c|c|}
\hline Whinger & Wrinop & 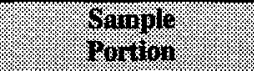 & 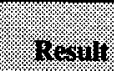 & Buplonsto & 48 \\
\hline 椾 & \multicolumn{2}{|c|}{ 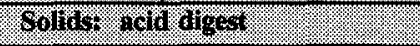 } & 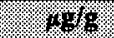 & 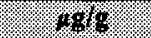 & 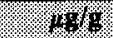 \\
\hline 2088 & \multirow[t]{2}{*}{ 43: 2} & Homogenized Test 1 & 3.89 & 4.46 & 4.175 \\
\hline 2089 & & Homogenized Test 2 & 3.86 & 4.04 & 3.95 \\
\hline 2092 & \multirow[t]{2}{*}{$43: 4$} & Homogenized Test 1 & 6.44 & 7.23 & 6.835 \\
\hline 2093 & & Homogenized Test 2 & 7.69 & 6.43 & 7.06 \\
\hline 2096 & \multirow[t]{2}{*}{$43: 6$} & Homogenized Test 1 & 3.39 & 3.9 & 3.645 \\
\hline 2097 & & Homogenized Test 2 & 4.4 & 4.32 & 4.36 \\
\hline 2171 & \multirow[t]{2}{*}{ Core 42} & Solid composite & 4.84 & 5.16 & 5 \\
\hline 2172 & & Solid composite & 6.42 & 5.79 & 6.105 \\
\hline
\end{tabular}


Table B2-40. Tank 241-S-104 Analytical Results: Titanium (ICP). (3 sheets)

\begin{tabular}{|c|c|c|c|c|c|}
\hline Mnuve & \%prom & . & $1+2=11$ & Mubliane & $6+2 \ln$ \\
\hline & \multicolumn{2}{|c|}{ 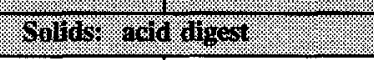 } & 186 & 68 & 48 \\
\hline 2175 & \multirow[t]{2}{*}{ Core 43} & Solid composite & 4.04 & 3.56 & 3.8 \\
\hline 2176 & & Solid composite & 4.09 & 3.93 & 4.01 \\
\hline 2177 & \multirow[t]{2}{*}{ Core 44} & Solid composite & 9.02 & 8.63 & 8.825 \\
\hline 2178 & & Solid composite & 10.7 & 9.97 & 10.335 \\
\hline \multicolumn{3}{|c|}{ 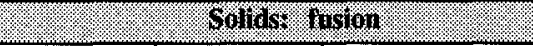 } & (48) & 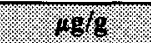 & 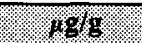 \\
\hline 2171 & \multirow[t]{2}{*}{ Core 42} & Solid composite & 3.5 & $<2$ & $<2.75$ \\
\hline 2172 & & Solid composite & 4.45 & 3.46 & 3.955 \\
\hline 2175 & \multirow[t]{2}{*}{ Core 43} & Solid composite & 11.5 & 8.68 & 10.09 \\
\hline 2176 & & Solid composite & 6.98 & 6.6 & 6.79 \\
\hline 2177 & \multirow[t]{2}{*}{ Core 44} & Solid composite & 10.1 & 7.18 & 8.64 \\
\hline 2178 & & Solid composite & 11.7 & 13.9 & 12.8 \\
\hline \multicolumn{3}{|c|}{ 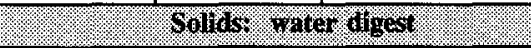 } & 48 & $.28 \mathrm{~g}$ & 189 \\
\hline 2171 & \multirow[t]{2}{*}{ Core 42} & Solid composite & $<0.41$ & 3.48 & $<1.94$ \\
\hline 2172 & & Solid composite & $<0 . \overline{41}$ & $<0.41$ & $<0.41$ \\
\hline 2175 & \multirow[t]{2}{*}{ Core 43} & Solid composite & 0.784 & $<0.5$ & $<0.64$ \\
\hline 2176 & & Solid composite & $<0.51$ & $<0.51$ & $<0.51$ \\
\hline 2177 & \multirow[t]{2}{*}{ Core 44} & Solid composite & $<0.51$ & $<0.51$ & $<0.51$ \\
\hline 2178 & & Solid composite & $<0.51$ & $<0.51$ & $<0.51$ \\
\hline \multicolumn{3}{|c|}{ 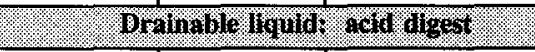 } & 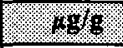 & 49 & $1.6 \%$ \\
\hline 2247 & 42: 1 & Drainable liquid & $<0.14$ & & $<0.14$ \\
\hline 2249 & 43: 1 & Drainable liquid & $<0.055$ & & $<0.055$ \\
\hline 2248 & 44: 1 & Drainable liquid & $<0.059$ & & $<0.059$ \\
\hline & \multicolumn{2}{|c|}{ Wher mintion } & 1898 & 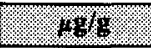 & 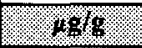 \\
\hline 2005 & \multirow[t]{5}{*}{$44: 6$} & Water dilution & $<0.32$ & $<0.4$ & $<0.362$ \\
\hline 2006 & & Water dilution & $<0.41$ & $<0.41$ & $<0.41$ \\
\hline 2007 & & Water dilution & $<0.40$ & $<0.40$ & $<0.40$ \\
\hline 2008 & & Water dilution & $<0.38$ & $<0.38$ & $<0.38$ \\
\hline 2010 & & Water dilution & $<0.68$ & $<0.69$ & $<0.69^{\mathrm{oc}: \mathrm{f}}$ \\
\hline
\end{tabular}


Table B2-40. Tank 241-S-104 Analytical Results: Titanium (ICP). (3 sheets)

\begin{tabular}{|c|c|c|c|c|c|}
\hline 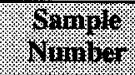 & 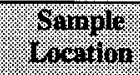 & 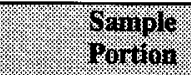 & 8,514 & Buplate & 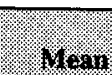 \\
\hline \multicolumn{3}{|c|}{ Kolids } & $18 \%$ & $10 \%$ & $14 \mathrm{cls}$ \\
\hline 2171 & \multirow[t]{2}{*}{ Core 42} & Solid composite & 7,100 & 6,510 & 6,805 \\
\hline 2172 & & Solid composite & 6,900 & 7,270 & 7,085 \\
\hline 2175 & \multirow[t]{2}{*}{ Core 43} & Solid composite & 7,060 & 6,520 & 6,790 \\
\hline 2176 & & Solid composite & 7,530 & 7,510 & 7,520 \\
\hline 2177 & \multirow[t]{2}{*}{ Core 44} & Solid composite & 6,140 & 6,210 & 6,175 \\
\hline 2178 & & Solid composite & 5,150 & 6,320 & 5,735 \\
\hline
\end{tabular}

Table B2-41. Tank 241-S-104 Analytical Results: Zinc (ICP). (2 sheets)

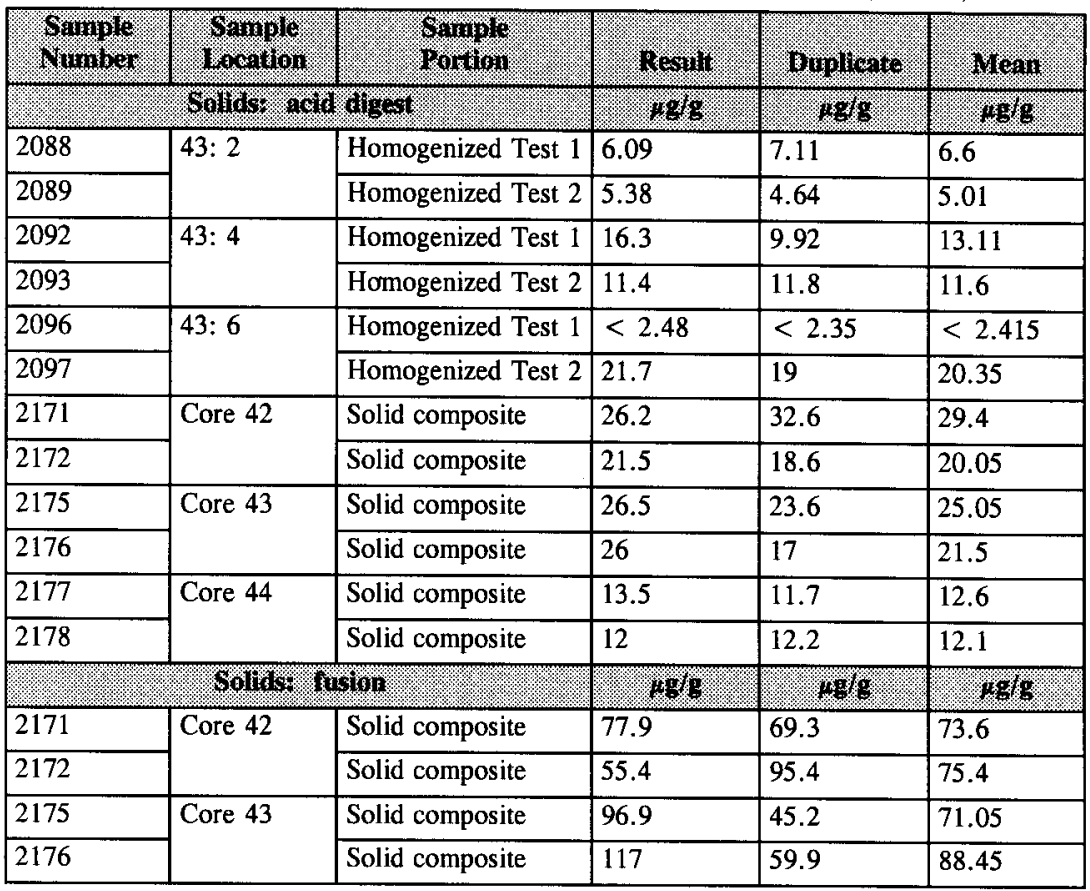


HNF-SD-WM-ER-370 Rev. 1

Table B2-41. Tank 241-S-104 Analytical Results: Zinc (ICP). (2 sheets)

\begin{tabular}{|c|c|c|c|c|c|}
\hline Wompos & \%oming & Wornol & Hesilit. & Bypligite & Hearis \\
\hline \multicolumn{3}{|c|}{ 90\% } & 46. & 168 & $8 \mathrm{~s}$ \\
\hline 2177 & \multirow[t]{2}{*}{ Core 44} & Solid composite & 234 & 206 & 220 \\
\hline 2178 & & Solid composite & 1,370 & 263 & 816.5 \\
\hline & \multicolumn{2}{|c|}{ 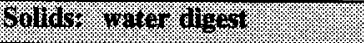 } & 49 & $18 \%$ & 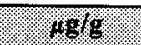 \\
\hline 2171 & \multirow[t]{2}{*}{ Core 42} & Solid composite & 19.5 & 44.6 & 32.05 \\
\hline 2172 & & Solid composite & 19.4 & 18.2 & 18.8 \\
\hline 2175 & \multirow[t]{2}{*}{ Core 43} & Solid composite & 13.9 & 13.9 & 13.9 \\
\hline 2176 & & Solid composite & 11.9 & 11.9 & 11.9 \\
\hline 2177 & \multirow[t]{2}{*}{ Core 44} & Solid composite & $<2.54$ & $<2.55$ & $<2.545$ \\
\hline 2178 & & Solid composite & 7.12 & $<2.55$ & $<4.835$ \\
\hline \multicolumn{3}{|c|}{ 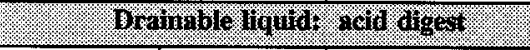 } & $10 \% 1 \%$ & 48: & $18 \%$ \\
\hline 2247 & 42: 1 & Drainable liquid & 7 & & $7^{\text {QC:f }}$ \\
\hline 2249 & 43: 1 & Drainable liquid & $<6.66406$ & & $<6.66406$ \\
\hline 2248 & 44: 1 & Drainable liquid & $<3.64844$ & & $<3.64844$ \\
\hline \multicolumn{3}{|c|}{ 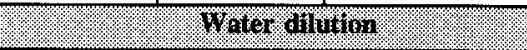 } & . 1879 & yeg & $14 \%$ \\
\hline 2005 & \multirow[t]{5}{*}{ 44: 6} & Water dilution & $<2.02$ & $<2.5$ & $<2.26$ \\
\hline 2006 & & Water dilution & 11.4 & $<2.53$ & $<6.965$ \\
\hline 2007 & & Water dilution & $<2.52$ & $<2.5$ & $<2.51$ \\
\hline 2008 & & Water dilution & 5.4 & 4.82 & 5.11 \\
\hline 2010 & & Water dilution & 4.45 & 1.43 & $2.94^{\mathrm{QC}: f}$ \\
\hline
\end{tabular}


Table B2-42. Tank 241-S-104 Analytical Results: Zirconium (ICP). (2 sheets)

\begin{tabular}{|c|c|c|c|c|c|}
\hline $\begin{array}{l}\text { Sample } \\
\text { Yumbor }\end{array}$ & $\begin{array}{l}\text { Somple: } \\
\text { Erontion }\end{array}$ & $\begin{array}{l}\text { Saraple } \\
\text { Yortion }\end{array}$ & Prosini: & Drulligrie & Mran \\
\hline 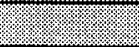 & \multicolumn{2}{|c|}{ Solings } & 180/: & $.19 \mathrm{~g}$ & 196 \\
\hline 2088 & \multirow[t]{2}{*}{$43: 2$} & Homogenized Test 1 & 24.2 & 25.8 & 25 \\
\hline 2089 & & Homogenized Test 2 & 25.6 & 26 & 25.8 \\
\hline 2092 & \multirow[t]{2}{*}{$43: 4$} & Homogenized Test 1 & 47 & \begin{tabular}{|l|}
46.4 \\
\end{tabular} & 46.7 \\
\hline 2093 & & Homogenized Test 2 & 46.8 & 44.8 & 45.8 \\
\hline 2096 & \multirow[t]{2}{*}{$43: 6$} & Homogenized Test 1 & 33.1 & 34.2 & 33.65 \\
\hline 2097 & & Homogenized Test 2 & 42 & 35.8 & 38.9 \\
\hline 2171 & \multirow[t]{2}{*}{ Core 42} & Solid composite & 32.3 & 30.9 & 31.6 \\
\hline 2172 & & Solid composite & 37 & 34.5 & 35.75 \\
\hline 2175 & \multirow[t]{2}{*}{ Core 43} & \begin{tabular}{|l|} 
Solid composite \\
\end{tabular} & 34.8 & 33.6 & 34.2 \\
\hline 2176 & & Solid composite & 34.3 & 35.5 & 34.9 \\
\hline 2177 & \multirow[t]{2}{*}{ Core 44} & Solid composite & 34.5 & 35.5 & 35 \\
\hline 2178 & & Solid composite & 31.5 & 29.3 & 30.4 \\
\hline$v_{2}$ & Sollus: & dusion : & 1482 & 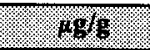 & 1096 \\
\hline 2171 & \multirow[t]{2}{*}{ Core 42} & Solid composite & 13.1 & 8.63 & 10.865 \\
\hline 2172 & & Solid composite & 4.85 & 12.5 & 8.675 \\
\hline 2175 & \multirow[t]{2}{*}{ Core 43} & Solid composite & 26 & 28.3 & 27.15 \\
\hline 2176 & & Solid composite & 29.7 & 37.9 & 33.8 \\
\hline 2177 & \multirow[t]{2}{*}{ Core 44} & Solid composite & 22.9 & 20.3 & 21.6 \\
\hline 2178 & & Solid composite & 20.9 & 29.4 & 25.15 \\
\hline & \multicolumn{2}{|c|}{ Sollidy forer agest: } & 989 & 1498 & $48 / 8$ \\
\hline 2171 & \multirow[t]{2}{*}{ Core 42} & Solid composite & $<0.813$ & $<0.808$ & $<0.8105$ \\
\hline 2172 & & Solid composite & $<0.813$ & $<0.816$ & $<0.8145$ \\
\hline 2175 & \multirow[t]{2}{*}{ Core 43} & Solid composite & $<1.1$ & $<1.1$ & $<1.1$ \\
\hline 2176 & & Solid composite & $<1.11$ & $<1.11$ & $<1.11$ \\
\hline 2177 & \multirow[t]{2}{*}{ Core 44} & Solid composite & $<1.12$ & $<1.12$ & $<1.12$ \\
\hline 2178 & & Solid composite & 1.2 & $<1.12$ & $<1.16$ \\
\hline
\end{tabular}


Table B2-42. Tank 241-S-104 Analytical Results: Zirconium (ICP). (2 sheets)

\begin{tabular}{|c|c|c|c|c|c|}
\hline $\begin{array}{l}\text { Gimple } \\
\text { Almimen }\end{array}$ & $\begin{array}{l}\text { Sumplo } \\
\text { Uncaton }\end{array}$ & $\begin{array}{l}\text { Somingle } \\
\text { Portibu }\end{array}$ & lesinil & Dupilicits & Vean \\
\hline \multicolumn{3}{|c|}{ 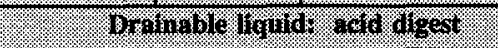 } & as/g: & 2018 & 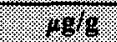 \\
\hline 2247 & 42: 1 & Drainable liquid & $<0.234375$ & & $\begin{array}{l}< \\
0.234375\end{array}$ \\
\hline 2249 & $43: 1$ & Drainable liquid & 0.094 & & $0.094^{\mathrm{QC}: \mathrm{f}}$ \\
\hline$\overline{2248}$ & $44: 1$ & Drainable liquid & 0.094 & & $0.094^{\mathrm{QC}: \mathrm{f}}$ \\
\hline \multicolumn{3}{|c|}{ 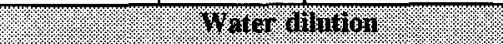 } & 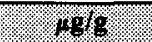 & 48 & 1886 \\
\hline 2005 & \multirow[t]{5}{*}{ 44: 6} & Water dilution & $<0.648$ & $<0.8$ & $<0.724$ \\
\hline 2006 & & Water dilution & $<0.809$ & $<0.811$ & $<0.81$ \\
\hline 2007 & & Water dilution & $<0.806$ & $<0.802$ & $<0.804$ \\
\hline 2008 & & Water dilution & $<0.76$ & $<0.76$ & $<0.76$ \\
\hline 2010 & & Water dilution & $<1.17$ & $<1.19$ & $<1.18$ \\
\hline
\end{tabular}

Table B2-43. Tank 241-S-104 Analytical Results: Ammonium (Distillation (NH3).

\begin{tabular}{|c|c|c|c|c|c|}
\hline $\begin{array}{l}\text { Shmple? } \\
\text { Number }\end{array}$ & $\begin{array}{l}\text { Simingle } \\
\text { Goconilon }\end{array}$ & $\begin{array}{l}\text { Shingle } \\
\text { Rontion }\end{array}$ & itesuit) & Oyiligane & Meran \\
\hline & Brananle & Wid & $10 \%$ & ifes & 185 \\
\hline 2245 & 42: 1 & Drainable liquid & 31.25 & & 31.25 \\
\hline 2245 & 43: 1 & Drainable liquid & $<31.25$ & & $<31.25$ \\
\hline 2245 & $44: 1$ & Drainable liquid & $<31.25$ & & $<31.25$ \\
\hline
\end{tabular}

Table B2-44. Tank 241-S-104 Analytical Results: Ammonium (Distillation).

\begin{tabular}{|c|c|c|c|c|c|}
\hline Shample & somplo & $\begin{array}{l}\text { Sarinple } \\
\text { roftion }\end{array}$ & Resiln & Buplicate & nean \\
\hline IS & \multicolumn{2}{|c|}{ SWiliner varer abest } & 7878 & 998 & 1088 \\
\hline 2171 & \multirow[t]{2}{*}{ Core 42} & Solid composite & $<4,500$ & $<4,500$ & $<4,500$ \\
\hline 2172 & & Solid composite & $<4,500$ & $<4,500$ & $<4,500$ \\
\hline 2175 & \multirow[t]{2}{*}{ Core 43} & Solid composite & $<4,500$ & $<4,500$ & $<4,500$ \\
\hline 2176 & & Solid composite & $<4,500$ & $<4,500$ & $<4,500$ \\
\hline 2177 & \multirow[t]{2}{*}{ Core 44} & Solid composite & $<9,000$ & $<9,000$ & $<9,000$ \\
\hline 2178 & & Solid composite & $<9,000$ & $<9,000$ & $<9,000$ \\
\hline
\end{tabular}


Table B2-45. Tank 241-S-104 Analytical Results: Carbonate (TIC).

\begin{tabular}{|c|c|c|c|c|c|}
\hline $\begin{array}{l}\text { Sample } \\
\text { Tumber: }\end{array}$ & 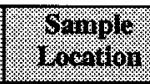 & $\begin{array}{l}\text { Somples } \\
\text { Portion }\end{array}$ & Resinit & Duplicale & Mear \\
\hline \multicolumn{3}{|c|}{ 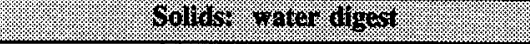 } & \% 8 & $.106 \mathrm{~g}$ & 1868 \\
\hline 2171 & \multirow[t]{2}{*}{ Core 42} & Solid composite & 2,490 & 3,020 & 2,755 \\
\hline 2172 & & Solid composite & 4,980 & 4,150 & 4,565 \\
\hline 2175 & \multirow[t]{2}{*}{ Core 43} & Solid composite & 3,330 & 3,180 & 3,255 \\
\hline 2176 & & Solid composite & 3,280 & 4,650 & 3,965 \\
\hline 2177 & \multirow[t]{2}{*}{ Core 44} & Solid composite & 3,540 & 2,390 & 2,965 \\
\hline 2178 & & Solid composite & 7,550 & 7,140 & 7,345 \\
\hline & \multicolumn{2}{|c|}{ Drotinable riquid } & 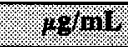 & ighini & 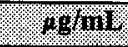 \\
\hline 2247 & 42: 1 & Drainable liquid & 1,370 & & $1,370^{\mathrm{QC}: \mathrm{f}}$ \\
\hline 2249 & 43: 1 & Drainable liquid & 1,030 & & $1,030^{\mathrm{QC}: \mathrm{f}}$ \\
\hline 2248 & 44: 1 & Drainable liquid & 922 & & $922^{\overline{Q C: f}}$ \\
\hline
\end{tabular}

Table B2-46. Tank 241-S-104 Analytical Results: Chloride (IC). (2 sheets)

\begin{tabular}{|c|c|c|c|c|c|}
\hline $\begin{array}{l}\text { Saruplo } \\
\text { Yurnber }\end{array}$ & $\begin{array}{l}\text { Siminple } \\
\text { Coctition }\end{array}$ & $\begin{array}{l}\text { Simple } \\
\text { romion. }\end{array}$ & Tesilit: & Muplowie. & Mean \\
\hline \multicolumn{3}{|c|}{ Bromable liguid } & 1848 & 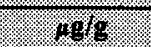 & $\mu b / 8$ \\
\hline 2247 & 42: 1 & Drainable liquid & 4,625 & & 4,625 \\
\hline 2249 & 43: 1 & Drainable liquid & 4,476 & & $4, \overline{476}$ \\
\hline 2248 & $44: 1$ & Drainable liquid & 5,875 & & 5,875 \\
\hline \multicolumn{3}{|c|}{ 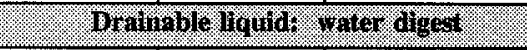 } & 1986. & 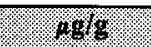 & 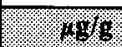 \\
\hline 2012 & \multirow[t]{6}{*}{$44: 1$} & Drainable liquid & 2,730 & 2,540 & 2,635 \\
\hline 2035 & & Drainable liquid & 172 & 158 & 165 \\
\hline 2181 & & Drainable liquid & 2,610 & 2,630 & 2,620 \\
\hline 2212 & & Drainable liquid & 3,210 & 3,100 & 3,155 \\
\hline 2235 & & Drainable liquid & 2,160 & 2,230 & 2,195 \\
\hline 2237 & & Drainable liquid & 3,620 & 4,340 & 3,980 \\
\hline
\end{tabular}


Table B2-46. Tank 241-S-104 Analytical Results: Chloride (IC). (2 sheets)

\begin{tabular}{|c|c|c|c|c|c|}
\hline $\begin{array}{l}\text { Simiple. } \\
\text { Number }\end{array}$ & $\begin{array}{c}\text { Sample } \\
\text { I cantor }\end{array}$ & $\begin{array}{l}\text { Sharnple } \\
\text { portion }\end{array}$ & Itenull & Oopticiro: & Viegn \\
\hline (17) & \multicolumn{2}{|c|}{ Solfur water disers } & $1=198$ & $1=184$ & 1. $19 \mathrm{~g}$ \\
\hline 2009 & $44: 6$ & $\begin{array}{l}\text { Final } 15 \mathrm{~cm} \\
(6 \text { in. })\end{array}$ & 2,160 & 2,230 & 2,195 \\
\hline 2171 & \multirow[t]{2}{*}{ Core 42} & Solid composite & 3,220 & 3,080 & 3,150 \\
\hline 2172 & & Solid composite & 3,130 & 3,100 & 3,115 \\
\hline 2175 & \multirow[t]{2}{*}{ Core 43} & Solid composite & 3,140 & 3,000 & 3,070 \\
\hline 2176 & & Solid composite & 2,950 & 3,220 & 3,085 \\
\hline 2177 & \multirow[t]{2}{*}{ Core 44} & Solid composite & 3,340 & 3,420 & 3,380 \\
\hline 2178 & & Solid composite & 3,260 & 3,520 & 3,390 \\
\hline
\end{tabular}

Note:

IC $=$ ion chromatography

Table B2-47. Tank 241-S-104 Analytical Results: Cyanide.

\begin{tabular}{|c|c|c|c|c|c|}
\hline $\begin{array}{l}\text { Sample } \\
\text { Number }\end{array}$ & $\begin{array}{l}\text { Shample. } \\
\text { Section. }\end{array}$ & $\begin{array}{l}\text { Somple } \\
\text { Portion. }\end{array}$ & Resull: & Bipleatis & 106 \\
\hline 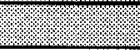 & Sol10 & & 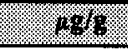 & 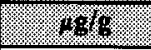 & 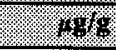 \\
\hline 2171 & \multirow[t]{2}{*}{ Core 42} & Solid composite & 3.96 & 4.12 & 4.04 \\
\hline 2172 & & Solid composite & 2.98 & 2.72 & 2.85 \\
\hline 2175 & \multirow[t]{2}{*}{ Core 43} & Solid composite & 4.15 & 3.84 & 3.995 \\
\hline 2176 & & Solid composite & 4.08 & 3.74 & 3.91 \\
\hline 2177 & \multirow[t]{2}{*}{ Core 44} & Solid composite & 4.3 & 3.94 & 4.12 \\
\hline 2178 & & Solid composite & 3.21 & 3.4 & 3.305 \\
\hline F & \multicolumn{2}{|c|}{ Girarnoble fiquin } & 1828 & 1089 & 4.896 \\
\hline 2247 & $42: 1$ & Drainable liquid & 2.14 & & 2.14 \\
\hline 2249 & 43: 1 & Drainable liquid & 2.09 & & 2.09 \\
\hline 2248 & 44: 1 & Drainable liquid & 2.06 & & 2.06 \\
\hline
\end{tabular}


Table B2-48. Tank 241-S-104 Analytical Results: Fluoride (IC).

\begin{tabular}{|c|c|c|c|c|c|}
\hline $\begin{array}{l}\text { Sample } \\
\text { Number }\end{array}$ & Goraiple & 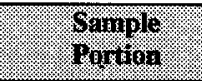 & pesill & Uuplicate & Wean \\
\hline \multicolumn{3}{|c|}{ Trangure iquir } & 14818 & remg & 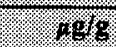 \\
\hline 2247 & $42: 1$ & Drainable liquid & 1,453 & & 1,453 \\
\hline 2249 & 43: 1 & Drainable liquid & 2,125 & & 2,125 \\
\hline 2248 & 44: 1 & Drainable liquid & 3,336 & & 3,336 \\
\hline \multicolumn{3}{|c|}{ Dranable liguiry vorer gegest } & 4848 & $188 \%$ & 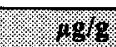 \\
\hline 2012 & 44: 1 & Drainable liquid & $<7.94$ & $<9.79$ & $<8.865$ \\
\hline 2035 & & Drainable liquid & $<109$ & $<109$ & $<109$ \\
\hline 2181 & & Drainable liquid & $<9.87$ & $<9.82$ & $<9.845$ \\
\hline 2212 & & Drainable liquid & $<9.29$ & $<9.34$ & $<9.315$ \\
\hline 2235 & & Drainable liquid & $<9.97$ & $<9.99$ & $<9.98$ \\
\hline \multicolumn{3}{|c|}{ Soldos: water dipest. } & $=188 / 5$ & woglo & 1286 \\
\hline 2009 & 44: 6 & $\begin{array}{l}\text { Final } 15 \mathrm{~cm} \\
(6 \text { in. })\end{array}$ & $<9.97$ & $<9.99$ & $<9.98$ \\
\hline 2171 & Core 42 & Solid composite & $<110$ & $<109$ & $<109.5$ \\
\hline 2172 & & Solid composite & $<110$ & $<110$ & $<110$ \\
\hline 2175 & Core 43 & Solid composite & $<108$ & $<108$ & $<108$ \\
\hline 2176 & & Solid composite & $<109$ & $<109$ & $<109$ \\
\hline 2177 & Core 44 & Solid composite & $<216$ & $<219$ & $<217.5$ \\
\hline 2178 & & Solid composite & $<219$ & $<218$ & $<218.5$ \\
\hline
\end{tabular}

Table B2-49. Tank 241-S-104 Analytical Results: Hydroxide (OH Automatic).

\begin{tabular}{|c|c|c|c|c|c|}
\hline $\begin{array}{l}\text { Simple } \\
\text { Tumber. }\end{array}$ & $\begin{array}{l}\text { Sanple } \\
\text { Gocation }\end{array}$ & $\begin{array}{l}\text { Samples } \\
\text { Tontion }\end{array}$ & 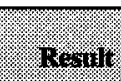 & Byoligit, & Mrosin. \\
\hline 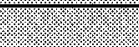 & \multicolumn{2}{|c|}{ Grairable ilguid } & (48) & Hinil: & Hof IVI \\
\hline 2247 & 42: 1 & Drainable liquid & 51,200 & & 51,200 \\
\hline 2249 & $43: 1$ & Drainable liquid & 40,500 & & 40,500 \\
\hline 2248 & $44: 1$ & Drainable liquid & 41,100 & & 41,100 \\
\hline
\end{tabular}


HNF-SD-WM-ER-370 Rev. 1

Table B2-50. Tank 241-S-104 Analytical Results: Nitrate (IC).

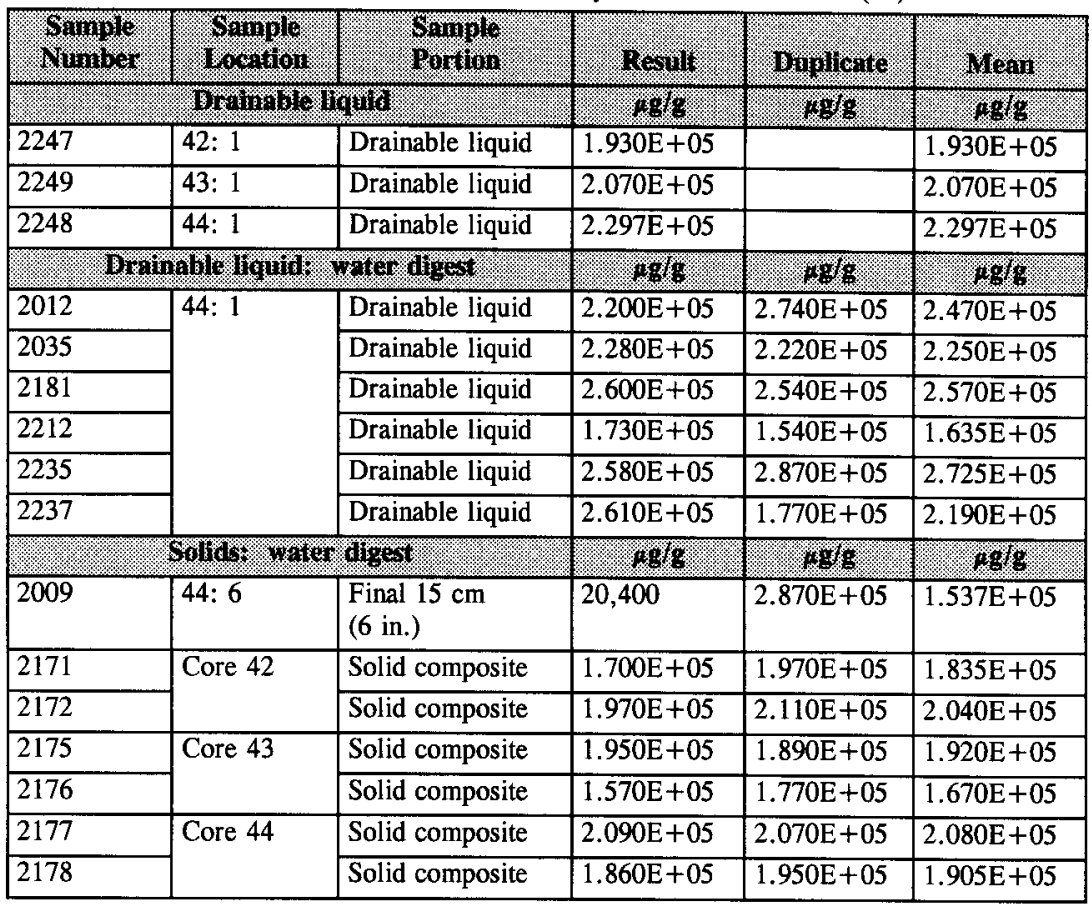

Table B2-51. Tank 241-S-104 Analytical Results: Nitrite (IC). (2 sheets)

\begin{tabular}{|c|c|c|c|c|c|}
\hline $\begin{array}{l}\text { Saringle } \\
\text { Nurnber. }\end{array}$ & $\begin{array}{l}\text { Sariplo } \\
\text { Location }\end{array}$ & $\begin{array}{l}\text { Siriple: } \\
\text { Fortion }\end{array}$ & Resuil: & Buplycalo & Nean \\
\hline \multicolumn{3}{|c|}{ 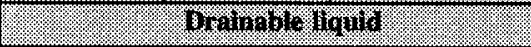 } & 180 & \%ts & 49 \\
\hline 2247 & 42: 1 & Drainable liquid & 34,375 & & 34,375 \\
\hline 2249 & 43: 1 & Drainable liquid & $<27,578.1$ & & $<27,578.1$ \\
\hline 2248 & 44: 1 & Drainable liquid & $27,656.2$ & & $27,656.2$ \\
\hline
\end{tabular}


HNF-SD-WM-ER-370 Rev. 1

Table B2-51. Tank 241-S-104 Analytical Results: Nitrite (IC). (2 sheets)

\begin{tabular}{|c|c|c|c|c|c|}
\hline . & \% & 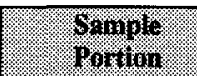 & osenil & Biglicate & Shan \\
\hline \multicolumn{3}{|c|}{ 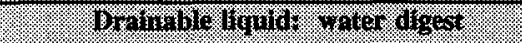 } & $4 \%$ & 86 & 80 \\
\hline 2012 & \multirow[t]{6}{*}{ 44: 1} & Drainable liquid & 10,400 & 10,500 & 10,450 \\
\hline 2035 & & Drainable liquid & 20,000 & 20,800 & 20,400 \\
\hline 2181 & & Drainable liquid & 23,000 & 23,400 & 23,200 \\
\hline 2212 & & Drainable liquid & 23,800 & 23,500 & 23,650 \\
\hline 2235 & & Drainable liquid & 20,400 & 20,800 & 20,600 \\
\hline 2237 & & Drainable liquid & 37,400 & 41,800 & 39,600 \\
\hline \multicolumn{3}{|c|}{ 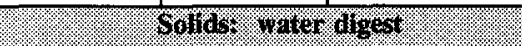 } & $8 y$ & $49 \%$ & 40 \\
\hline 2009 & $44: 6$ & $\begin{array}{l}\text { Final } 15 \mathrm{~cm} \\
(6 \text { in. })\end{array}$ & 2,580 & 20,800 & 11,690 \\
\hline 2171 & \multirow[t]{2}{*}{ Core 42} & Solid composite & 22,100 & 20,600 & 21,350 \\
\hline 2172 & & Solid composite & 19,800 & 19,900 & 19,850 \\
\hline 2175 & \multirow[t]{2}{*}{ Core 43} & Solid composite & 19,200 & 16,600 & 17,900 \\
\hline 2176 & & Solid composite & 17,700 & 19,300 & 18,500 \\
\hline 2177 & \multirow[t]{2}{*}{ Core 44} & Solid composite & 22,800 & 22,700 & 22,750 \\
\hline 2178 & & Solid composite & 23,300 & 25,700 & 24,500 \\
\hline
\end{tabular}

Table B2-52. Tank 241-S-104 Analytical Results: Nitrite (Spectrophotometric). (2 sheets)

\begin{tabular}{|c|c|c|c|c|c|}
\hline 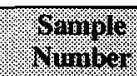 & 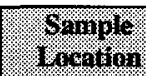 & 191191 & Besull & Oupiofic & Merin \\
\hline \multicolumn{3}{|c|}{ 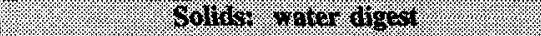 } & 80 & 88 & 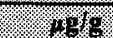 \\
\hline 2171 & \multirow[t]{2}{*}{ Core 42} & Solid composite & 28,400 & 25,800 & 27,100 \\
\hline 2172 & & Solid composite & 26,100 & 24,800 & 25,450 \\
\hline 2175 & \multirow[t]{2}{*}{ Core 43} & Solid composite & 29,800 & 26,600 & 28,200 \\
\hline 2176 & & Solid composite & 20,400 & 21,200 & 20,800 \\
\hline 2177 & \multirow[t]{2}{*}{ Core 44} & Solid composite & 26,500 & 26,700 & 26,600 \\
\hline 2178 & & Solid composite & 24,800 & 29,400 & 27,100 \\
\hline
\end{tabular}


HNF-SD-WM-ER-370 Rev. 1

Table B2-52. Tank 241-S-104 Analytical Results: Nitrite (Spectrophotometric). (2 sheets)

\begin{tabular}{|c|c|c|c|c|c|}
\hline 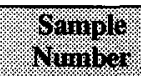 & a & 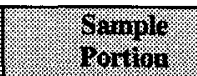 & Keruil & 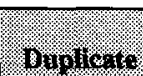 & Mean \\
\hline \multicolumn{2}{|c|}{ 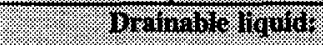 } & 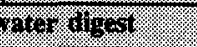 & 1048 & $1 \%$ & (1) \\
\hline 2012 & \multirow[t]{6}{*}{ 44: 1} & Drainable liquid & 24,000 & 22,100 & 23,050 \\
\hline 2035 & & Drainable liquid & 28,000 & 25,500 & 26,750 \\
\hline 2181 & & Drainable liquid & 23,700 & 23,300 & 23,500 \\
\hline 2212 & & Drainable liquid & 26,500 & 26,600 & 26,550 \\
\hline 2235 & & Drainable liquid & 21,000 & 21,500 & 21,250 \\
\hline 2237 & & Drainable liquid & 31,400 & 38,900 & 35,150 \\
\hline
\end{tabular}

Table B2-53. Tank 241-S-104 Analytical Results: Phosphate (IC).

\begin{tabular}{|c|c|c|c|c|c|}
\hline (4omplo & Wompol & 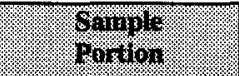 & Irovil & 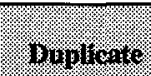 & $1+2=1$ \\
\hline \multicolumn{3}{|c|}{ 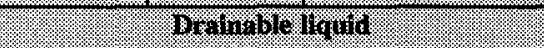 } & 48 & 48\% & 48 \\
\hline 2247 & 42: 1 & Drainable liquid & $<0.78$ & & $<0.78$ \\
\hline 2249 & 43: 1 & Drainable liquid & 0.78 & & $0 . \overline{78}$ \\
\hline 2248 & $44: 1$ & Drainable liquid & $<0.78$ & & $<0.78$ \\
\hline \multicolumn{2}{|c|}{ 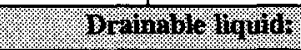 } & trater. 619 & .496 & 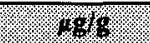 & 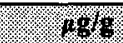 \\
\hline 2012 & \multirow{6}{*}{$44: 1$} & Drainable liquid & $<79.4$ & $<97.9$ & $<88.65$ \\
\hline 2035 & & Drainable liquid & $<1,090$ & $<1,090$ & $<1,090$ \\
\hline 2181 & & Drainable liquid & $<98.9$ & $<98.2$ & $<98.55$ \\
\hline 2212 & & Drainable liquid & $<92.9$ & $<93.4$ & $<93.15$ \\
\hline 2235 & & Drainable liquid & $<99.7$ & $<99.9$ & $<99.8$ \\
\hline 2237 & & Drainable liquid & $<95.5$ & $<96.9$ & $<\overline{96.2}$ \\
\hline \multicolumn{3}{|c|}{ 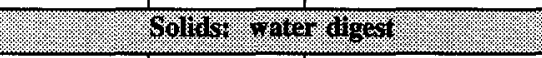 } & 1998 & 48 & 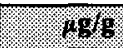 \\
\hline 2009 & $44: 6$ & Final $15 \mathrm{~cm}(6$ in. $)$ & $<99.7$ & $<99.9$ & $<99.8$ \\
\hline 2171 & \multirow[t]{2}{*}{ Core 42} & Solid composite & $<1,100$ & $<1,090$ & $<1,095$ \\
\hline 2172 & & Solid composite & $<1,100$ & $<1,100$ & $<1,100$ \\
\hline 2175 & \multirow[t]{2}{*}{ Core 43} & Solid composite & $<1,080$ & $<1,080$ & $<1,080$ \\
\hline 2176 & & Solid composite & $<1,090$ & $<1,090$ & $<1,090$ \\
\hline 2177 & \multirow[t]{2}{*}{ Core 44} & Solid composite & $<2,160$ & $<2,190$ & $<2,175$ \\
\hline 2178 & & Solid composite & $<2,190$ & $<2,180$ & $<2,185$ \\
\hline
\end{tabular}


HNF-SD-WM-ER-370 Rev. 1

Table B2-54. Tank 241-S-104 Analytical Results: Sulfate (IC).

\begin{tabular}{|c|c|c|c|c|c|}
\hline $\begin{array}{l}\text { Simple: } \\
\text { Niminer: }\end{array}$ & 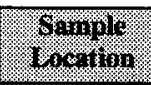 & $\begin{array}{l}\text { Simigle } \\
\text { Surtion }\end{array}$ & pesting & Hulisive & vera \\
\hline \multicolumn{3}{|c|}{ 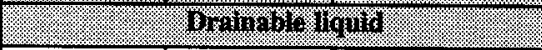 } & 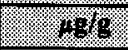 & 48.9 & 1908. \\
\hline 2247 & 42: 1 & Drainable liquid & 4,940 & & 4,940 \\
\hline 2249 & 43: 1 & Drainable liquid & 10,000 & & 10,000 \\
\hline 2248 & 44: 1 & Drainable liquid & 41,560 & & 41,560 \\
\hline \multicolumn{3}{|c|}{ 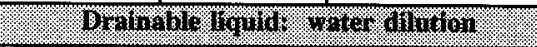 } & 1480 & 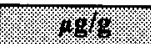 & $1.60 \mathrm{~g}$ \\
\hline 2012 & \multirow[t]{6}{*}{$44: 1$} & Drainable liquid & 1,640 & 1,420 & 1,530 \\
\hline 2035 & & Drainable liquid & 1,790 & 1,830 & 1,810 \\
\hline 2181 & & Drainable liquid & $1, \overline{500}$ & 1,510 & 1,505 \\
\hline 2212 & & Drainable liquid & 1,860 & 1,800 & 1,830 \\
\hline 2235 & & Drainable liquid & 1,670 & 1,680 & 1,675 \\
\hline 2237 & & Drainable liquid & 3,000 & 3,180 & 3,090 \\
\hline 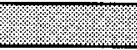 & \multicolumn{2}{|c|}{ Soldo: yoter digest } & 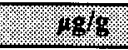 & 1408 & 1896 \\
\hline 2009 & $44: 6$ & $\begin{array}{l}\text { Final } 15 \mathrm{~cm} \\
(6 \text { in.) }\end{array}$ & 1,670 & 1,630 & 1,650 \\
\hline 2171 & \multirow[t]{2}{*}{\begin{tabular}{|l|} 
Core 42 \\
\end{tabular}} & Solid composite & 2,520 & 2,250 & 2,385 \\
\hline 2172 & & Solid composite & 2,520 & 2,270 & 2,395 \\
\hline 2175 & \multirow[t]{2}{*}{ Core 43} & Solid composite & 2,410 & 2,010 & 2,210 \\
\hline 2176 & & Solid composite & 2,370 & 2,240 & 2,305 \\
\hline 2177 & \multirow[t]{2}{*}{ Core 44} & Solid composite & 2,200 & 2,170 & 2,185 \\
\hline 2178 & & Solid composite & 2,170 & 2,160 & 2,165 \\
\hline
\end{tabular}


Table B2-55. Tank 241-S-104 Analytical Results: Americium-241 (GEA).

\begin{tabular}{|c|c|c|c|c|c|}
\hline $\begin{array}{l}\text { Samines. } \\
\text { Number: }\end{array}$ & 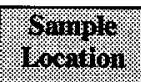 & 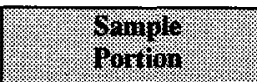 & Resalin & Thpisase & Mitan \\
\hline & \multicolumn{2}{|c|}{ 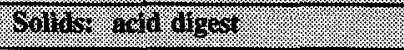 } & 1.119 & rew: & $10 \%$ \\
\hline 2088 & \multirow[t]{2}{*}{ 43: 2} & Homogenized Test 1 & $<0.703$ & $<0.717$ & $<0.71$ \\
\hline 2089 & & Homogenized Test 2 & $<0.732$ & $<0.722$ & $<0.727$ \\
\hline 2092 & \multirow[t]{2}{*}{$43: 4$} & Homogenized Test 1 & $<0.269$ & $<0.262$ & $<0.2655$ \\
\hline 2093 & & Homogenized Test 2 & $<0.125$ & $<0.124$ & $<0.1245$ \\
\hline 2096 & \multirow[t]{2}{*}{$43: 6$} & Homogenized Test 1 & $<0.163$ & $<0.169$ & $<0.166$ \\
\hline 2097 & & Homogenized Test 2 & $<0.171$ & $<0.179$ & $<0.175$ \\
\hline & Soritis. & Horion & 10\%, & \% W & 1018 \\
\hline 2171 & \multirow[t]{2}{*}{ Core 42} & Solid composite & $<0.699$ & $<0.679$ & $<0.689$ \\
\hline 2172 & & Solid composite & $<0.695$ & $<0.69$ & $<0.6925$ \\
\hline 2175 & \multirow[t]{2}{*}{ Core 43} & Solid composite & $<0.434$ & $<0.432$ & $<0.433$ \\
\hline 2176 & & Solid composite & $<0.439$ & $<0.424$ & $<0.4315$ \\
\hline 2177 & \multirow[t]{2}{*}{ Core 44} & Solid composite & $<0.267$ & $<0.266$ & $<0.2665$ \\
\hline 2178 & & Solid composite & $<0.258$ & $<0.262$ & $<0.26$ \\
\hline & \multicolumn{2}{|c|}{ Jrinable liguido } & FGIm) & (1) 1 mor. & COHin \\
\hline 2247 & $42: 1$ & Drainable liquid & $<0.105$ & & $<0.105$ \\
\hline 2249 & 43: 1 & Drainable liquid & $<0.105$ & & $<0.105$ \\
\hline 2248 & $44: 1$ & Drainable liquid & $<0.11$ & & $<0.11$ \\
\hline
\end{tabular}


Table B2-56. Tank 241-S-104 Analytical Results: Americium-241 (Alpha Spectrometry).

\begin{tabular}{|c|c|c|c|c|c|}
\hline Squing & Goning & $40 \% 1818$ & I $=2 ; 01 \%$ & Byolusate & 166 \\
\hline \multicolumn{3}{|c|}{ 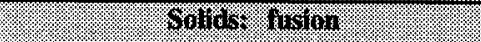 } & H 13 & 8\% & KY) \\
\hline 2171 & \multirow[t]{2}{*}{ Core 42} & Solid composite & 0.111 & 0.111 & 0.111 \\
\hline 2172 & & Solid composite & 0.118 & 0.116 & 0.117 \\
\hline 2175 & \multirow[t]{2}{*}{ Core 43} & Solid composite & 0.12 & 0.12 & 0.12 \\
\hline 2176 & & Solid composite & 0.14 & 0.12 & 0.13 \\
\hline 2177 & \multirow[t]{2}{*}{ Core 44} & Solid composite & 0.117 & 0.129 & 0.123 \\
\hline 2178 & & Solid composite & 0.109 & 0.113 & 0.111 \\
\hline \multicolumn{3}{|c|}{ 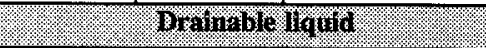 } & \%ONII & WOIII & WOH \\
\hline 2247 & 42: 1 & Drainable liquid & $<8.150 \mathrm{E}-05$ & & $<8.150 \mathrm{E}-05$ \\
\hline 2249 & 43: 1 & Drainable liquid & $<7.490 \mathrm{E}-05$ & & $<7.490 \mathrm{E}-05$ \\
\hline 2248 & $44: 1$ & Drainable liquid & $<6.720 \mathrm{E}-05$ & & $<6.720 \mathrm{E}-05$ \\
\hline
\end{tabular}

Table B2-57. Tank 241-S-104 Analytical Results: Carbon-14.

\begin{tabular}{|c|c|c|c|c|c|}
\hline SOM & \% & 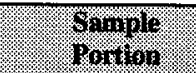 & $14=11$ & Myerloro & 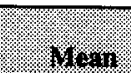 \\
\hline \multicolumn{3}{|c|}{ (6) $14.6 \%$} & roy & 46 & is. \\
\hline 2171 & \multirow[t]{2}{*}{ Core 42} & Solid composite & 0.001 & $6.900 \mathrm{E}-05$ & $5.345 \mathrm{E}-04$ \\
\hline 2172 & & Solid composite & $9.070 \mathrm{E}-04$ & 0.00112 & 0.0010135 \\
\hline 2175 & \multirow[t]{2}{*}{ Core 43} & Solid composite & $5.080 \mathrm{E}-04$ & $6.150 \mathrm{E}-04$ & $5.615 \mathrm{E}-04$ \\
\hline 2176 & & Solid composite & 0.00108 & $9.580 \mathrm{E}-04$ & 0.001019 \\
\hline 2177 & \multirow[t]{2}{*}{ Core 44} & Solid composite & 0.00102 & 0.00118 & 0.0011 \\
\hline 2178 & & Solid composite & 0.00114 & 0.00122 & 0.00118 \\
\hline
\end{tabular}


Table B2-58. Tank 241-S-104 Analytical Results: Cesium-137 (GEA).

\begin{tabular}{|c|c|c|c|c|c|}
\hline $\begin{array}{l}\text { Somple } \\
\text { Sumper }\end{array}$ & 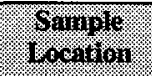 & $\begin{array}{l}\text { Shmplo } \\
\text { : }\end{array}$ & Tesill: & Bouilsate. & (10.in \\
\hline \multicolumn{3}{|c|}{ 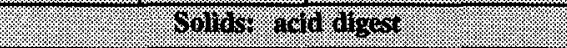 } & $\mathrm{ACIb}$ & "Crlg & 7018 \\
\hline 2088 & \multirow[t]{2}{*}{$43: 2$} & Homogenized Test 1 & 52.9 & 53.7 & 53.3 \\
\hline 2089 & & Homogenized Test 2 & 52.9 & 54.2 & 53.55 \\
\hline 2092 & \multirow[t]{2}{*}{$43: 4$} & Homogenized Test 1 & 63.5 & 61.1 & 62.3 \\
\hline 2093 & & Homogenized Test 2 & 51.5 & 49.6 & 50.55 \\
\hline 2096 & \multirow[t]{2}{*}{$43: 6$} & Homogenized Test 1 & 47.1 & 53.6 & 50.35 \\
\hline 2097 & & Homogenized Test 2 & 53.9 & 59 & 56.45 \\
\hline 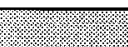 & Sorlids? & ferion & $1 / 01 \%$ & Werive & 1.14\% \\
\hline 2171 & \multirow[t]{2}{*}{ Core 42} & Solid composite & 67.5 & 62 & 64.75 \\
\hline 2172 & & Solid composite & 66.1 & 62.6 & 64.35 \\
\hline 2175 & \multirow[t]{2}{*}{ Core 43} & Solid composite & 60.2 & 60.3 & 60.25 \\
\hline 2176 & & Solid composite & 58.3 & 55.7 & 57 \\
\hline 2177 & \multirow[t]{2}{*}{ Core 44} & Solid composite & 63.1 & 64 & 63.55 \\
\hline 2178 & & Solid composite & 63.9 & 64 & 63.95 \\
\hline & \multicolumn{2}{|c|}{ Drainable Iquiro } & 1\% VIring. & moni. & r. \\
\hline 2247 & 42: 1 & Drainable liquid & 78 & & 78 \\
\hline 2249 & 43: 1 & Drainable liquid & 78.1 & & $<78.1$ \\
\hline 2248 & 44: 1 & Drainable liquid & 86.5 & & 86.5 \\
\hline
\end{tabular}


Table B2-59. Tank 241-S-104 Analytical Results: Cobalt-60 (GEA).

\begin{tabular}{|c|c|c|c|c|c|}
\hline Sarmple & $\begin{array}{l}\text { Sornolo: } \\
\text { rocation. }\end{array}$ & $\begin{array}{l}\text { Semple } \\
\text { Portion }\end{array}$ & kesili & Mopligife. & 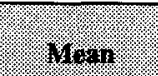 \\
\hline 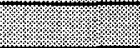 & \multicolumn{2}{|c|}{ Gollh } & 1016 & 10 & merc \\
\hline 2088 & \multirow[t]{2}{*}{$43: 2$} & Homogenized Test 1 & $<0.0446$ & $<0.0383$ & $<0.04145$ \\
\hline 2089 & & Homogenized Test 2 & $<0.0478$ & $<0.0442$ & $<0.046$ \\
\hline 2092 & \multirow[t]{2}{*}{$43: 4$} & Homogenized Test 1 & $<0.0143$ & $<0.013$ & $<0.01365$ \\
\hline 2093 & & Homogenized Test 2 & $<0.00394$ & $<0.0455$ & $<0.02472$ \\
\hline 2096 & \multirow[t]{2}{*}{$43: 6$} & Homogenized Test 1 & $<0.00689$ & $<0.0069$ & $<0.006895$ \\
\hline 2097 & & Homogenized Test 2 & $<0.0059$ & $<0.00594$ & $<0.00592$ \\
\hline (1) & \multicolumn{2}{|c|}{ Sollider fusting } & 1996 & . 14 & . $101 / 6$ \\
\hline 2171 & \multirow[t]{2}{*}{ Core 42} & Solid composite & $<0.063$ & $<0.084$ & $<0.0735$ \\
\hline 2172 & & Solid composite & $<0.062$ & $<0.07$ & $<0.06605$ \\
\hline 2175 & \multirow[t]{2}{*}{ Core 43} & Solid composite & $<0.0325$ & $<0.0333$ & $<0.0329$ \\
\hline 2176 & & Solid composite & $<0.032$ & $<0.034$ & $<0.033$ \\
\hline 2177 & \multirow[t]{2}{*}{ Core 44} & Solid composite & $<0.0135$ & $<0.0137$ & $<0.0136$ \\
\hline 2178 & & Solid composite & $<0.0143$ & $<0.0138$ & $<0.01405$ \\
\hline 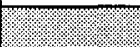 & \multicolumn{2}{|c|}{ Dramalle liquiro } & PCrmI & (4. & Horint \\
\hline 2247 & $42: 1$ & Drainable liquid & $<0.0025$ & & $<0.0025$ \\
\hline 2249 & 43: 1 & Drainable liquid & 0.00257 & & 0.00257 \\
\hline 2248 & $44: 1$ & Drainable liquid & $<0.00246$ & & $<0.00246$ \\
\hline
\end{tabular}

Table B2-60. Tank 241-S-104 Analytical Results: Europium-154 (GEA). (2 sheets)

\begin{tabular}{|c|c|c|c|c|c|}
\hline $\begin{array}{l}\text { Thample } \\
\text { Number }\end{array}$ & $\begin{array}{l}\text { Sample: } \\
\text { Eoration }\end{array}$ & $\begin{array}{l}\text { Samplo } \\
\text { Iortan }\end{array}$ & Resull & Buplicus? & Mrean. \\
\hline & \multirow{3}{*}{$\frac{0.0136}{43: 2}$} & 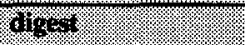 & mety & TC: & HOtr: \\
\hline 2088 & & Homogenized Test 1 & $<0.174$ & $<0.15$ & $<0.162$ \\
\hline 2089 & & Homogenized Test 2 & $<0.122$ & $<0.132$ & $<0.127$ \\
\hline 2092 & \multirow[t]{2}{*}{$43: 4$} & Homogenized Test 1 & $<0.03$ & $<0.0353$ & $<0.03265$ \\
\hline 2093 & & Homogenized Test 2 & $<0.15$ & $<0.169$ & $<0.1595$ \\
\hline 2096 & \multirow[t]{2}{*}{ 43: 6} & Homogenized Test 1 & 0.095 & 0.121 & 0.108 \\
\hline 2097 & & Homogenized Test 2 & 0.12 & 0.107 & 0.1135 \\
\hline
\end{tabular}


Table B2-60. Tank 241-S-104 Analytical Results: Europium-154 (GEA). (2 sheets)

\begin{tabular}{|c|c|c|c|c|c|}
\hline $\begin{array}{l}\text { Sarmole } \\
\text { Number. }\end{array}$ & $\begin{array}{l}\text { Simingle } \\
\text { Eocontion }\end{array}$ & 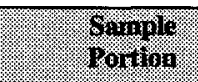 & $x=311$ & 8) & Viran \\
\hline & \multicolumn{2}{|c|}{ Soldas re rision } & HOF & 14 & 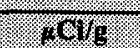 \\
\hline 2171 & \multirow[t]{2}{*}{ Core 42} & Solid composite & $<0.237$ & $<0.317$ & $<0.277$ \\
\hline 2172 & & Solid composite & $<0.269$ & $<0.235$ & $<0.252$ \\
\hline 2175 & \multirow[t]{2}{*}{ Core 43} & Solid composite & $<0.0821$ & $<0.0984$ & $<0.09025$ \\
\hline 2176 & & Solid composite & $<0.085$ & $<0.093$ & $<0.089$ \\
\hline 2177 & \multirow[t]{2}{*}{ Core 44} & Solid composite & $<0.0379$ & $<0.0411$ & $<0.0395$ \\
\hline 2178 & & Solid composite & $<0.0372$ & $<0.0433$ & $<0.04025$ \\
\hline & \multicolumn{2}{|c|}{ 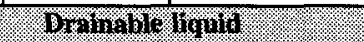 } & HOWnit & 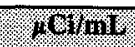 & ACWII. \\
\hline 2247 & $42: 1$ & Drainable liquid & $<0.00967$ & & $<0.00967$ \\
\hline 2249 & $43: 1$ & Drainable liquid & $<0.00834$ & & $<0.00834$ \\
\hline 2248 & $44: 1$ & Drainable liquid & $<0.00948$ & & $<0.00948$ \\
\hline
\end{tabular}

Table B2-61. Tank 241-S-104 Analytical Results: Europium-155 (GEA). (2 sheets)

\begin{tabular}{|c|c|c|c|c|c|}
\hline $\begin{array}{l}\text { Sample } \\
\text { Number }\end{array}$ & Sariplo & $\begin{array}{l}\text { Sumple } \\
\text { Eortion }\end{array}$ & ILsinil: & $84016=0 \%$ & 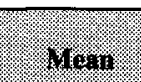 \\
\hline ?t: & Soller : & oritoly & 1908. & $409 \mathrm{~g}$ & 4019. \\
\hline 2088 & \multirow{2}{*}{$43: 2$} & Homogenized Test 1 & $<0.332$ & $<0.33$ & $<0.331$ \\
\hline 2089 & & Homogenized Test 2 & $<0.328$ & $<0.322$ & $<0.325$ \\
\hline 2092 & \multirow[t]{2}{*}{$43: 4$} & Homogenized Test 1 & $<0.116$ & $<0.114$ & $<0.115$ \\
\hline 2093 & & Homogenized Test 2 & $<0.2$ & $<0.2$ & $<0.2$ \\
\hline 2096 & \multirow[t]{2}{*}{$43: 6$} & Homogenized Test 1 & $<0.0712$ & $<0.0736$ & $<0.0724$ \\
\hline 2097 & & Homogenized Test 2 & $<0.0745$ & $<0.0782$ & $<0.07635$ \\
\hline & Soltivis & firision & (c)igs & $10 \%$ & $14 \mathrm{dr} / \mathrm{g}$ \\
\hline 2171 & \multirow[t]{2}{*}{ Core 42} & Solid composite & $<0.461$ & $<0.447$ & $<0.454$ \\
\hline 2172 & & Solid composite & $<0.463$ & $<0.454$ & $<0.4585$ \\
\hline 2175 & \multirow[t]{2}{*}{ Core 43} & Solid composite & $<0.186$ & $<0.188$ & $<0.187$ \\
\hline 2176 & & Solid composite & $<0.188$ & $<0.184$ & $<0.186$ \\
\hline 2177 & \multirow[t]{2}{*}{ Core 44} & Solid composite & $<0.115$ & $<0.116$ & $<0.1155$ \\
\hline 2178 & & Solid composite & $<0.113$ & $<0.115$ & $<0.114$ \\
\hline
\end{tabular}


HNF-SD-WM-ER-370 Rev. 1

Table B2-61. Tank 241-S-104 Analytical Results: Europium-155 (GEA). (2 sheets)

\begin{tabular}{|c|c|c|c|c|c|}
\hline Wentor & 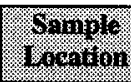 & 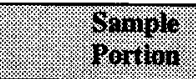 & (rosil) & Buplitos & Lean \\
\hline \multicolumn{3}{|c|}{ B) } & 64111 & $\%$ & (X) \\
\hline 2247 & 42: 1 & Drainable liquid & $<0.0449$ & & $<0.0449$ \\
\hline 2249 & 43: 1 & Drainable liquid & $<0.0449$ & & $<0.0449$ \\
\hline 2248 & 44: 1 & Drainable liquid & $<0.047$ & & $<0.047$ \\
\hline
\end{tabular}

Table B2-62. Tank 241-S-104 Analytical Results: Iodine-129.

\begin{tabular}{|c|c|c|c|c|c|}
\hline Ninglof & ong & 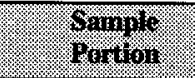 & Wesint & Ouinilgate & $41+211$ \\
\hline \multicolumn{3}{|c|}{ Wolf } & \% & 10. & (1) \\
\hline 2171 & \multirow[t]{2}{*}{ Core 42} & Solid composite & $<0.0196$ & $<0.0196$ & $<0.0196$ \\
\hline 2172 & & Solid composite & $<0.0125$ & $<0.0244$ & $<0.01845$ \\
\hline 2175 & \multirow[t]{2}{*}{ Core 43} & Solid composite & $<0.0172$ & $<0.0132$ & $<0.0152$ \\
\hline 2176 & & Solid composite & $<0.0143$ & $<0.0136$ & $<0.01395$ \\
\hline 2177 & \multirow[t]{2}{*}{ Core 44} & Solid composite & $<0.0162$ & $<0.0214$ & $<0.0188$ \\
\hline 2178 & & Solid composite & $<0.0334$ & $<0.0154$ & $<0.0244$ \\
\hline
\end{tabular}

Table B2-63. Tank 241-S-104 Analytical Results: Neptunium-237.

\begin{tabular}{|c|c|c|c|c|c|}
\hline \%ั1 & S401010 & 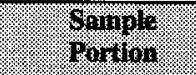 & mositi: & Hollindt= & Herin \\
\hline \multicolumn{3}{|c|}{$0016 \%$ Hor } & 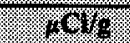 & 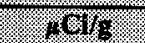 & (1) \\
\hline 2171 & \multirow[t]{2}{*}{ Core 42} & Solid composite & $<0.0216$ & $<0.0216$ & $<0.0216$ \\
\hline 2172 & & Solid composite & $<0.021$ & $<0.0080$ & $<0.015$ \\
\hline 2175 & \multirow[t]{2}{*}{ Core 43} & Solid composite & $<0.0215$ & $<0.0214$ & $<0.02145$ \\
\hline 2176 & & Solid composite & $<0.021$ & $<0.021$ & $<0.0212$ \\
\hline 2177 & \multirow[t]{2}{*}{ Core 44} & Solid composite & $<0.021$ & $<0.022$ & $<0.021$ \\
\hline 2178 & & Solid composite & $<0.0107$ & $<0.0107$ & $<0.0107$ \\
\hline
\end{tabular}


Table B2-64. Tank 241-S-104 Analytical Results: Plutonium-238 (Alpha Spectrometry).

\begin{tabular}{|c|c|c|c|c|c|}
\hline (6) & 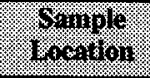 & f. & Mrsyix & Pyoteris & Wear \\
\hline \multicolumn{3}{|c|}{ ofolido } & W/ $/{ }_{1}$ & 46 & 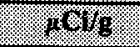 \\
\hline 2168 & $42: 6$ & $\begin{array}{l}\text { Final } 15 \mathrm{~cm} \\
(6 \text { in. })\end{array}$ & $<0.009$ & $<0.00898$ & $<0.00899$ \\
\hline 2166 & $43: 6$ & $\begin{array}{l}\text { Final } 15 \mathrm{~cm} \\
(6 \text { in. })\end{array}$ & $<0.0045$ & $<0.0045$ & $<0.00445$ \\
\hline 2162 & $44: 6$ & $\begin{array}{l}\text { Final } 15 \mathrm{~cm} \\
(6 \text { in. })\end{array}$ & $<0.00893$ & $<0.00892$ & $<0.00893$ \\
\hline \multicolumn{3}{|c|}{ 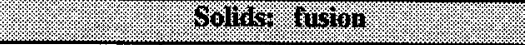 } & no. & 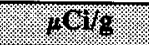 & (2) \\
\hline 2171 & \multirow[t]{2}{*}{ Core 42} & Solid composite & $<0.00901$ & $<0.00901$ & $<0.00901$ \\
\hline 2172 & & Solid composite & $<0.0089$ & $<0.0090$ & $<0.0089$ \\
\hline 2175 & \multirow[t]{2}{*}{ Core 43} & Solid composite & $<0.018$ & $<0.018$ & $<0.018$ \\
\hline 2176 & & Solid composite & $<0.018$ & $<0.018$ & $<0.018$ \\
\hline 2177 & \multirow[t]{2}{*}{ Core 44} & Solid composite & $<0.018$ & $<0.018$ & $<0.0179$ \\
\hline 2178 & & Solid composite & $<0.018$ & $<0.018$ & $<0.018$ \\
\hline
\end{tabular}

Table B2-65. Tank 241-S-104 Analytical Results: Plutonium-238 to Plutonium Ratio (Mass Spectrometry).

\begin{tabular}{|c|c|c|c|c|c|}
\hline Shining & 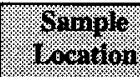 & (3) & $\mathrm{d}=811$ & Moplicase & 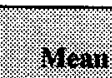 \\
\hline \multicolumn{3}{|c|}{ 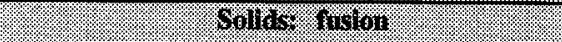 } & 46 & \% & \% \\
\hline 93-1075-H1 & $42: 6$ & Partial & 0.012 & 0.01 & 0.011 \\
\hline $93-1755-\mathrm{H} 1$ & $43: 6$ & Whole & 0.01 & 0.01 & 0.01 \\
\hline $93-1754-\mathrm{H1}$ & $44: 6$ & Partial & 0.011 & 0.014 & 0.0125 \\
\hline 93-1076-H1 & \multirow[t]{2}{*}{ Core 42} & Solid composite & 0.009 & 0.01 & 0.0095 \\
\hline 93-1756-H1 & & Solid composite & 0.011 & 0.008 & 0.0095 \\
\hline $93-1758-\mathrm{H} 1$ & \multirow[t]{2}{*}{ Core 43} & Solid composite & 0.009 & 0.009 & 0.009 \\
\hline 93-1757-H1 & & Solid composite & 0.008 & 0.009 & 0.0085 \\
\hline 93-1759-H1 & \multirow[t]{2}{*}{ Core 44} & Solid composite & 0.009 & 0.009 & 0.009 \\
\hline $93-1760-\mathrm{H} 1$ & & Solid composite & 0.009 & 0.009 & 0.009 \\
\hline
\end{tabular}


Table B2-66. Tank 241-S-104 Analytical Results: Plutonium-239/40 (Alpha Spectrometry).

\begin{tabular}{|c|c|c|c|c|c|}
\hline $\begin{array}{l}\text { Somple } \\
\text { Nimile }\end{array}$ & $\begin{array}{l}\text { Sample } \\
\text { 1 cosidion }\end{array}$ & $\begin{array}{l}\text { Sampiry } \\
\text { rortion }\end{array}$ & pesin: & Byplionla & Vrean \\
\hline $4=$ & \multicolumn{2}{|c|}{$481 \%$} & (16: & 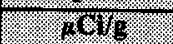 & काषs \\
\hline 2168 & $42: 6$ & $\begin{array}{l}\text { Final } 15 \mathrm{~cm} \\
(6 \text { in. })\end{array}$ & 0.354 & 0.295 & 0.3245 \\
\hline 2166 & 43: 6 & $\begin{array}{l}\text { Final } 15 \mathrm{~cm} \\
(6 \text { in. })\end{array}$ & 0.129 & 0.142 & 0.1355 \\
\hline 2162 & $44: 6$ & $\begin{array}{l}\text { Final } 15 \mathrm{~cm} \\
(6 \text { in. })\end{array}$ & 0.185 & 0.209 & 0.197 \\
\hline 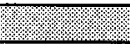 & \multicolumn{2}{|c|}{ 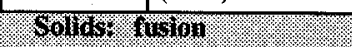 } & 1216 & 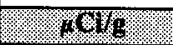 & 10\% \\
\hline 2171 & \multirow[t]{2}{*}{ Core 42} & Solid composite & 0.137 & 0.136 & 0.1365 \\
\hline 2172 & & Solid composite & 0.157 & 0.154 & 0.1555 \\
\hline 2175 & \multirow[t]{2}{*}{ Core 43} & Solid composite & 0.296 & 0.314 & 0.305 \\
\hline 2176 & & Solid composite & $\overline{0.385}$ & 0.361 & 0.373 \\
\hline $21 \overline{77}$ & \multirow[t]{2}{*}{ Core 44} & Solid composite & 0.365 & 0.404 & 0.3845 \\
\hline 2178 & & Solid composite & 0.366 & 0.31 & 0.338 \\
\hline 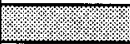 & \multicolumn{2}{|c|}{ 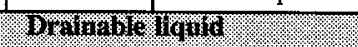 } & m GIII. & 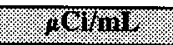 & 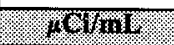 \\
\hline 2247 & $42: 1$ & Drainable liquid & $<1.370 \mathrm{E}-04$ & & $<1.370 \mathrm{E}-04$ \\
\hline 2249 & 43: 1 & Drainable liquid & $<6.410 \mathrm{E}-05$ & & $<6.410 \mathrm{E}-05$ \\
\hline 2248 & $44: 1$ & Drainable liquid & $<6.880 \mathrm{E}-05$ & & $<6.880 \mathrm{E}-05$ \\
\hline
\end{tabular}

Table B2-67. Tank 241-S-104 Analytical Results: Plutonium-239 to Plutonium Ratio (Mass Spectrometry).

\begin{tabular}{|c|c|c|c|c|c|}
\hline $\begin{array}{l}\text { Samples: } \\
\text { Number. }\end{array}$ & 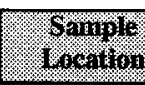 & $\begin{array}{l}\text { Simiple: } \\
\text { portion }\end{array}$ & Rowinit & Dipilicate & nosn \\
\hline (.6. & \multicolumn{2}{|c|}{ Solus? rusing } & \% & 8 & $\%$ \\
\hline 93-1075-H1 & $42: 6$ & Partial & 95 & 95 & 95 \\
\hline 93-1755-H1 & $43: 6$ & Whole & 95 & 95 & 95 \\
\hline 93-1754-H1 & $44: 6$ & Partial & 95 & 95 & 95 \\
\hline 93-1076-H1 & \multirow[t]{2}{*}{ Core 42} & Solid composite & 95 & 95 & 95 \\
\hline 93-1756-H1 & & Solid composite & 95 & 95 & 95 \\
\hline 93-1758-H1 & \multirow[t]{2}{*}{ Core 43} & Solid composite & 95 & 95 & $\overline{95}$ \\
\hline 93-1757-H1 & & Solid composite & 95 & 95 & 95 \\
\hline 93-1759-H1 & \multirow[t]{2}{*}{ Core 44} & Solid composite & 95 & 95 & 95 \\
\hline 93-1760-H1 & & Solid composite & 95 & 95 & 95 \\
\hline
\end{tabular}


Table B2-68. Tank 241-S-104 Analytical Results: Plutonium-240 to Plutonium Ratio (Mass Spectrometry).

\begin{tabular}{|c|c|c|c|c|c|}
\hline $\begin{array}{l}\text { Sample } \\
\text { Tumber }\end{array}$ & $\begin{array}{l}\text { Sample } \\
\text { lisurition }\end{array}$ & $\begin{array}{l}\text { Sanple } \\
\text { Poridon }\end{array}$ & Rerair & Gupllate & Mran \\
\hline 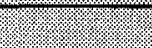 & \multicolumn{2}{|c|}{ 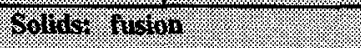 } & \%. & $\%$ & $\%$ \\
\hline 93-1075-H1 & 42: 6 & Partial & 4.96 & 4.91 & 4.93 \\
\hline 93-1755-H1 & 43: 6 & Whole & 4.92 & 4.91 & 4.92 \\
\hline 93-1754-H1 & $44: 6$ & \begin{tabular}{|l|} 
Partial \\
\end{tabular} & 4.95 & 5.02 & \begin{tabular}{|l|}
4.99 \\
\end{tabular} \\
\hline 93-1076-H1 & \multirow[t]{2}{*}{ Core 42} & Solid composite & 4.83 & 5.15 & 5.0 \\
\hline 93-1756-H1 & & Solid composite & 5.06 & 5.03 & 5.05 \\
\hline 93-1758-H1 & \multirow[t]{2}{*}{ Core 43} & Solid composite & 5.01 & 4.93 & 4.97 \\
\hline 93-1757-H1 & & Solid composite & 5.00 & 5.01 & 5.01 \\
\hline 93-1759-H1 & \multirow[t]{2}{*}{ Core 44} & Solid composite & 5.03 & 5.07 & 5.05 \\
\hline $93-1760-\mathrm{H} 1$ & & Solid composite & 5.0 & 4.97 & 4.98 \\
\hline
\end{tabular}

Table B2-69. Tank 241-S-104 Analytical Results: Plutonium-241 to Plutonium Ratio (Mass Spectrometry).

\begin{tabular}{|c|c|c|c|c|c|}
\hline 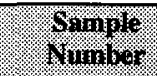 & $\begin{array}{l}\text { Sumiple } \\
\text { Crention }\end{array}$ & 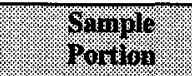 & Reswar) & Topllasate & 4han \\
\hline 2 & \multicolumn{2}{|c|}{ 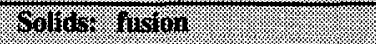 } & \%. & \% & 9 \\
\hline $93-1075-\mathrm{H} 1$ & 42: 6 & Partial & 0.054 & 0.077 & 0.065 \\
\hline 93-1755-H1 & $43: 6$ & Whole & 0.054 & 0.053 & 0.054 \\
\hline 93-1754-H1 & $44: 6$ & Partial & 0.052 & 0.070 & 0.061 \\
\hline 93-1076-H1 & \multirow[t]{2}{*}{ Core 42} & Solid composite & 0.069 & 0.11 & 0.090 \\
\hline 93-1756-H1 & & Solid composite & 0.053 & 0.060 & 0.056 \\
\hline 93-1758-H1 & \multirow[t]{2}{*}{ Core 43} & Solid composite & 0.055 & 0.054 & 0.055 \\
\hline 93-1757-h1 & & Solid composite & 0.080 & 0.053 & 0.066 \\
\hline 93-1759-H1 & \multirow[t]{2}{*}{ Core 44} & Solid composite & 0.073 & 0.055 & 0.064 \\
\hline $93-1760-\mathrm{H} 1$ & & Solid composite & 0.058 & 0.061 & 0.060 \\
\hline
\end{tabular}


HNF-SD-WM-ER-370 Rev. 1

Table B2-70. Tank 241-S-104 Analytical Results: Plutonium-242 to Plutonium Ratio (Mass Spectrometry).

\begin{tabular}{|c|c|c|c|c|c|}
\hline $\begin{array}{l}\text { Sainple: } \\
\text { Vumber }\end{array}$ & Somple & $\begin{array}{l}\text { Swomple } \\
\text { rortion }\end{array}$ & Iresultit & Guplicite & Mean \\
\hline 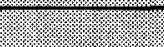 & \multicolumn{2}{|l|}{ Sollist liwion } & $\%$ & (8. & $\%$ \\
\hline 93-1075-H1 & $42: 6$ & Partial & 0.0129 & 0.0122 & 0.013 \\
\hline 93-1755-H1 & $43: 6$ & Whole & 0.013 & 0.011 & 0.012 \\
\hline 93-1754-H1 & $44: 6$ & Partial & 0.0105 & 0.0241 & 0.0173 \\
\hline 93-1076-H1 & \multirow[t]{2}{*}{ Core 42} & Solid composite & 0.0256 & 0.0527 & 0.039 \\
\hline 93-1756-H1 & & Solid composite & 0.0405 & 0.0151 & 0.0278 \\
\hline 93-1758-H1 & \multirow[t]{2}{*}{ Core 43} & Solid composite & 0.0179 & 0.0122 & 0.015 \\
\hline 93-1757-H1 & & Solid composite & 0.0263 & 0.0151 & 0.021 \\
\hline 93-1759-H1 & \multirow[t]{2}{*}{ Core 44} & Solid composite & 0.0241 & 0.0178 & 0.021 \\
\hline 93-1760-H1 & & Solid composite & 0.0075 & 0.0288 & 0.018 \\
\hline
\end{tabular}

Table B2-71. Tank 241-S-104 Analytical Results: Selenium-79.

\begin{tabular}{|c|c|c|c|c|c|}
\hline $\begin{array}{l}\text { Simingle } \\
\text { Nuniber }\end{array}$ & $\begin{array}{l}\text { Gamingle } \\
\text { Iscation }\end{array}$ & $\begin{array}{l}\text { Sample } \\
\text { Toution }\end{array}$ & Resuli, & Bupioilc & Mean \\
\hline (2) & Solus & Horin & (19\%8 & $1.0 \%$ & reirs. \\
\hline 2171 & \multirow[t]{2}{*}{ Core 42} & Solid composite & $<1.240 \mathrm{E}-04$ & $<1.270 \mathrm{E}-04$ & $<1.255 \mathrm{E}-04$ \\
\hline 2172 & & Solid composite & 0.0013 & $<1.260 \mathrm{E}-04$ & $<7.130 \mathrm{E}-04$ \\
\hline 2175 & \multirow[t]{2}{*}{ Core 43} & Solid composite & $<1.210 \mathrm{E}-04$ & $<1.220 \mathrm{E}-04$ & $<1.215 \mathrm{E}-04$ \\
\hline 2176 & & Solid composite & $<1.230 \mathrm{E}-04$ & $<1.230 \mathrm{E}-04$ & $<1.230 \mathrm{E}-04$ \\
\hline 2177 & \multirow[t]{2}{*}{ Core 44} & Solid composite & $<1.440 \mathrm{E}-04$ & $<1.480 \mathrm{E}-04$ & $<1.460 \mathrm{E}-04$ \\
\hline 2178 & & Solid composite & $<1.420 \mathrm{E}-04$ & $<1.470 \mathrm{E}-04$ & $<1.445 \mathrm{E}-04$ \\
\hline
\end{tabular}


HNF-SD-WM-ER-370 Rev. 1

Table B2-72. Tank 241-S-104 Analytical Results: Strontium-90.

\begin{tabular}{|c|c|c|c|c|c|}
\hline 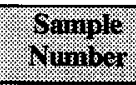 & 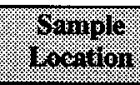 & . 109010 & tily & Bifligase & 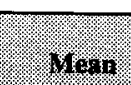 \\
\hline & \multicolumn{2}{|c|}{ 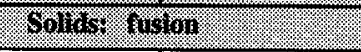 } & $6 y_{8}$ & $2 \%$ & (1) \\
\hline 2171 & \multirow[t]{2}{*}{ Core 42} & Solid composite & 295 & 281 & 288 \\
\hline 2172 & & Solid composite & 339 & 310 & 324.5 \\
\hline 2175 & \multirow[t]{2}{*}{ Core 43} & Solid composite & 305 & 300 & 302.5 \\
\hline 2176 & & Solid composite & 310 & 345 & 327.5 \\
\hline 2177 & \multirow[t]{2}{*}{ Core 44} & Solid composite & 299 & 356 & 327.5 \\
\hline 2178 & & Solid composite & 272 & 303 & 287.5 \\
\hline \multicolumn{3}{|c|}{ 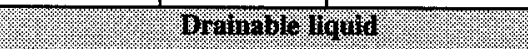 } & \% 1110 & WHY & (4) \\
\hline 2247 & 42: 1 & Drainable liquid & 0.0030 & & $0.0030^{\text {QC:f }}$ \\
\hline 2249 & $43: 1$ & Drainable liquid & 0.010 & & $0.010^{\mathrm{QC}: f}$ \\
\hline 2248 & $44: 1$ & Drainable liquid & 0.0024 & & $0.0024^{\mathrm{QC:f}}$ \\
\hline
\end{tabular}

Table B2-73. Tank 241-S-104 Analytical Results: Technetium-99.

\begin{tabular}{|c|c|c|c|c|c|}
\hline (4011\%1\% & W11010 & . & mering & 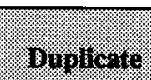 & Mon \\
\hline \multicolumn{3}{|c|}{ 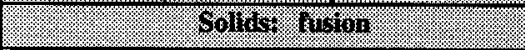 } & 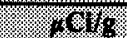 & Wh & (x) \\
\hline 2171 & \multirow[t]{2}{*}{ Core 42} & Solid composite & 0.0271 & 0.0235 & 0.0253 \\
\hline 2172 & & Solid composite & 0.0261 & 0.026 & 0.026 \\
\hline 2175 & \multirow[t]{2}{*}{ Core 43} & Solid composite & 0.023 & 0.021 & 0.022 \\
\hline 2176 & & Solid composite & 0.0213 & 0.0209 & 0.0211 \\
\hline 2177 & \multirow[t]{2}{*}{ Core 44} & Solid composite & 0.0281 & 0.0283 & 0.0282 \\
\hline 2178 & & Solid composite & 0.022 & 0.023 & 0.022 \\
\hline
\end{tabular}


Table B2-74. Tank 241-S-104 Analytical Results: Tritium (Liquid Scintillation).

\begin{tabular}{|c|c|c|c|c|c|}
\hline 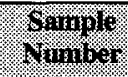 & \%मn10 & 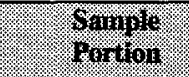 & Revilit & Buri isale & Hen \\
\hline \multicolumn{3}{|c|}{ 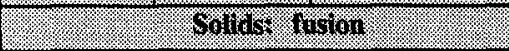 } & $1 / 4$ & (1) & (4) \\
\hline 2171 & \multirow[t]{2}{*}{ Core 42} & Solid composite & 0.0019 & 0.002 & 0.00195 \\
\hline 2172 & & Solid composite & 0.00334 & 0.00583 & 0.0046 \\
\hline 2175 & \multirow[t]{2}{*}{ Core 43} & Solid composite & 0.00316 & 0.00314 & 0.00315 \\
\hline 2176 & & Solid composite & 0.00277 & 0.00313 & 0.00295 \\
\hline 2177 & \multirow[t]{2}{*}{ Core 44} & Solid composite & 0.00319 & 0.00328 & 0.0032 \\
\hline 2178 & & Solid composite & 0.00321 & 0.00556 & 0.0044 \\
\hline
\end{tabular}

Table B2-75. Tank 241-S-104 Analytical Results: Uranium-234 to Uranium Ratio (Mass Spectrometry).

\begin{tabular}{|c|c|c|c|c|c|}
\hline $\begin{array}{l}\text { Sample } \\
\text { Armber }\end{array}$ & $\begin{array}{l}\text { Saningle } \\
\text { Wocution. }\end{array}$ & $\begin{array}{l}\text { Smimples: } \\
\text { forrion }\end{array}$ & ressily & Hipligarte & Mear \\
\hline 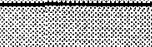 & \multicolumn{2}{|c|}{ Sollds: 0 (10) } & \%) & 8 & \% \\
\hline $93-1075-\mathrm{Hl}$ & $42: 6$ & Partial & 0.0056 & 0.0063 & 0.00595 \\
\hline $93-1755-\mathrm{H} 1$ & $43: 6$ & Whole & 0.0057 & 0.0056 & 0.00565 \\
\hline 93-1754-H1 & $44: 6$ & Partial & 0.0053 & 0.0047 & 0.005 \\
\hline 93-1076-H1 & \multirow[t]{2}{*}{ Core 42} & Solid composite & 0.0027 & 0.0064 & 0.00455 \\
\hline $93-1756-\mathrm{H} 1$ & & Solid composite & 0.0069 & 0.0047 & 0.0058 \\
\hline 93-1758-H1 & \multirow[t]{2}{*}{ Core 43} & Solid composite & 0.009 & 0.0053 & 0.00715 \\
\hline $03-1757-\mathrm{H} 1$ & & Solid composite & 0.0032 & 0.0061 & 0.00465 \\
\hline 93-1759-H1 & \multirow[t]{2}{*}{ Core 44} & Solid composite & $\overline{0.006}$ & 0.0053 & 0.00565 \\
\hline $93-1760-\mathrm{H} 1$ & & Solid composite & 0.0071 & 0.005 & 0.00605 \\
\hline
\end{tabular}


HNF-SD-WM-ER-370 Rev. 1

Table B2-76. Tank 241-S-104 Analytical Results: Uranium-235 to Uranium Ratio (Mass Spectrometry).

\begin{tabular}{|c|c|c|c|c|c|}
\hline $\begin{array}{l}\text { Srample } \\
\text { Nuimber. }\end{array}$ & 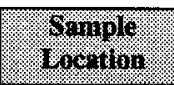 & $\begin{array}{l}\text { Sample } \\
\text { Iumbar } \\
\end{array}$ & romitis & olopiche & Men \\
\hline 1.: & \multicolumn{2}{|c|}{ Sollor THon } & $\%$ & $1.8 \%$ & \%) \\
\hline $93-1075-\mathrm{H} 1$ & $42: 6$ & Partial & 0.65 & 0.65 & 0.65 \\
\hline $93-1755-\mathrm{H} 1$ & $43: 6$ & Whole & 0.64 & 0.64 & 0.64 \\
\hline 93-1754-H1 & 44: 6 & Partial & 0.65 & 0.65 & 0.65 \\
\hline 93-1076-H1 & \multirow[t]{2}{*}{ Core 42} & Solid composite & 0.65 & 0.65 & 0.65 \\
\hline 93-1756-H1 & & Solid composite & 0.64 & 0.65 & 0.65 \\
\hline 93-1758-H1 & \multirow[t]{2}{*}{ Core 43} & Solid composite & 0.65 & 0.65 & 0.65 \\
\hline 93-1757-H1 & & Solid composite & 0.65 & 0.65 & 0.65 \\
\hline 93-1759-H1 & \multirow[t]{2}{*}{ Core 44} & Solid composite & 0.65 & 0.65 & 0.65 \\
\hline 93-1760-H1 & & Solid composite & 0.65 & 0.64 & 0.65 \\
\hline
\end{tabular}

Table B2-77. Tank 241-S-104 Analytical Results: Uranium-236 to Uranium Ratio (Mass Spectrometry).

\begin{tabular}{|c|c|c|c|c|c|}
\hline $\begin{array}{l}\text { Sample } \\
\text { Yiminer }\end{array}$ & $\begin{array}{l}\text { Sample } \\
\text { Tocouron }\end{array}$ & $\begin{array}{l}\text { Sample: } \\
\text { rortion }\end{array}$ & Inorit & Tingliante & 14/8m \\
\hline 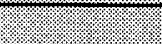 & \multicolumn{2}{|c|}{ Solingr fingion } & \% & \% & \% \\
\hline $93-1075-\mathrm{H} 1$ & $42: 6$ & Partial & 0.0112 & 0.0109 & 0.011 \\
\hline 93-1755-H1 & $43: 6$ & Whole & 0.0098 & 0.0103 & 0.010 \\
\hline 93-1754-H1 & $44: 6$ & Partial & 0.0123 & 0.011 & 0.012 \\
\hline 93-1076-H1 & \multirow[t]{2}{*}{ Core 42} & Solid composite & 0.0065 & 0.0082 & 0.0074 \\
\hline 93-1756-H1 & & Solid composite & 0.0109 & 0.0124 & 0.0117 \\
\hline 93-1758-H1 & \multirow[t]{2}{*}{ Core 43} & Solid composite & 0.0105 & 0.0104 & 0.0105 \\
\hline 93-1757-H1 & & Solid composite & 0.0037 & 0.011 & 0.00735 \\
\hline 93-1759-H1 & \multirow[t]{2}{*}{ Core 44} & Solid composite & 0.0102 & 0.0096 & 0.0099 \\
\hline 93-1760-H1 & & Solid composite & 0.0097 & 0.0111 & 0.0104 \\
\hline
\end{tabular}


Table B2-78. Tank 241-S-104 Analytical Results: Uranium-238 to Uranium Ratio (Mass Spectrometry).

\begin{tabular}{|c|c|c|c|c|c|}
\hline $\begin{array}{l}\text { Samine } \\
\text { Number }\end{array}$ & $\begin{array}{l}\text { Swriple: } \\
\text { Eocition. }\end{array}$ & $\begin{array}{l}\text { Sample } \\
\text { rourtion }\end{array}$ & Res:nit & nopinicate & 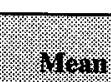 \\
\hline 8 & \multicolumn{2}{|c|}{ 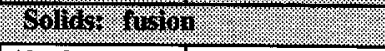 } & 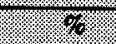 & (3) & $\frac{86}{86}$ \\
\hline 93-1075-H1 & $42: 6$ & Partial & 99 & 99 & 99 \\
\hline 93-1755-H1 & $43: 6$ & Whole & 99 & 99 & 99 \\
\hline 93-1754-H1 & $44: 6$ & Partial & 99 & 99 & 99 \\
\hline 93-1076-H1 & \multirow[t]{2}{*}{ Core 42} & Solid composite & 99 & 99 & 99 \\
\hline 93-1756-H1 & & Solid composite & 99 & 99 & 99 \\
\hline 93-1758-H1 & \multirow[t]{2}{*}{ Core 43} & Solid composite & 99 & 99 & 99 \\
\hline 93-1757-H1 & & Solid composite & 99 & 99 & 99 \\
\hline 93-1759-H1 & \multirow[t]{2}{*}{ Core 44} & Solid composite & 99 & 99 & 99 \\
\hline 93-1760-H1 & & Solid composite & 99 & 99 & 99 \\
\hline
\end{tabular}

Table B2-79. Tank 241-S-104 Analytical Results: Total Alpha.

\begin{tabular}{|c|c|c|c|c|c|}
\hline 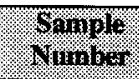 & $\begin{array}{l}\text { Simpipl } \\
\text { learitio }\end{array}$ & $\begin{array}{l}\text { Samples: } \\
\text { fortion. }\end{array}$ & Gesul: & 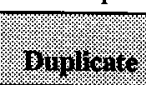 & Mean: \\
\hline & \multicolumn{2}{|c|}{ 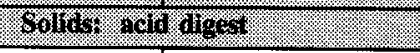 } & Halls & .1.8\% & $10 \% 8$ \\
\hline 2088 & \multirow[t]{2}{*}{$43: 2$} & Homogenized Test 1 & 0.34 & 0.363 & 0.352 \\
\hline 2089 & & Homogenized Test 2 & 0.291 & $<0.302$ & $<0.30$ \\
\hline 2092 & \multirow[t]{2}{*}{$43: 4$} & Homogenized Test 1 & 0.778 & 0.823 & 0.80 \\
\hline 2093 & & Homogenized Test 2 & 0.503 & 0.457 & 0.48 \\
\hline 2096 & \multirow[t]{2}{*}{$43: 6$} & Homogenized Test 1 & 0.428 & 0.393 & 0.41 \\
\hline 2097 & & Homogenized Test 2 & $0 . \overline{455}$ & 0.441 & $\overline{0.448}$ \\
\hline P & \multicolumn{2}{|c|}{ Brainable Truor } & FTWI. & MGinY & Hotran \\
\hline 2245 & 43: 1 & Drainable liquid & 0.188 & & 0.188 \\
\hline 2245 & $44: 1$ & Drainable liquid & 0.228 & & 0.228 \\
\hline 1.9 & \multicolumn{2}{|c|}{ Sollidis: forion } & 12618 & 16/y & Heris \\
\hline 2171 & \multirow[t]{2}{*}{ Core 42} & Solid composite & 0.701 & $<0.352$ & $<0.5265$ \\
\hline 2172 & & Solid composite & 0.578 & $<0.72$ & $<0.649$ \\
\hline 2175 & \multirow[t]{2}{*}{ Core 43} & Solid composite & 0.807 & 0.779 & 0.793 \\
\hline 2176 & & Solid composite & 0.998 & 0.916 & 0.957 \\
\hline 2177 & \multirow[t]{2}{*}{ Core 44} & Solid composite & 0.432 & 0.489 & 0.461 \\
\hline 2178 & & Solid composite & 0.39 & 0.239 & 0.315 \\
\hline
\end{tabular}


Table B2-80. Tank 241-S-104 Analytical Results: Total Alpha Plutonium.

\begin{tabular}{|c|c|c|c|c|c|}
\hline $\begin{array}{l}\text { Samples: } \\
\text { Nimber. }\end{array}$ & $\begin{array}{l}\text { Sample: } \\
\text { Ercation. }\end{array}$ & $\begin{array}{l}\text { Sample: } \\
\text { Voortion }\end{array}$ & Resull & Ouplisate. & Mean \\
\hline$\sqrt{7.8 .8}$ & \multicolumn{2}{|c|}{ Goling Tision } & $=2010$ & NC18: & $18 \% 8$ \\
\hline 93-1075-H1 & $42: 6$ & Partial & 0.259 & 0.335 & $0.297^{\mathrm{QC}: \mathrm{f}}$ \\
\hline 93-1755-H1 & $43: 6$ & Whole & 0.334 & 0.305 & $0.32^{\mathrm{QC:f}}$ \\
\hline 93-1754-H1 & $44: 6$ & Partial & $\overline{0.35}$ & 0.376 & $0.36^{\text {QC:f }}$ \\
\hline 93-1076-H1 & \multirow[t]{2}{*}{ Core 42} & Solid composite & 0.401 & 0.373 & $0.387^{\mathrm{QC:f}}$ \\
\hline 93-1756-H1 & & Solid composite & 0.335 & 0.328 & 0.332 \\
\hline 93-1758-H1 & \multirow[t]{2}{*}{ Core 43} & Solid composite & 0.428 & 0.431 & $0.43^{\mathrm{OC} . \mathrm{f}}$ \\
\hline $93-1757-\mathrm{H} 1$ & & Solid composite & 0.454 & 0.487 & $0.47^{\mathrm{QC:f}}$ \\
\hline $93-1759-\mathrm{H} 1$ & \multirow[t]{2}{*}{ Core 44} & Solid composite & 0.405 & 0.424 & $0.415^{\mathrm{QC}: \mathrm{f}}$ \\
\hline 93-1760-H1 & & Solid composite & 0.407 & 0.401 & $0.404^{\mathrm{QC}: \mathrm{f}}$ \\
\hline
\end{tabular}

Table B2-81. Tank 241-S-104 Analytical Results: Ratio of Total Alpha to Plutonium + Americium.

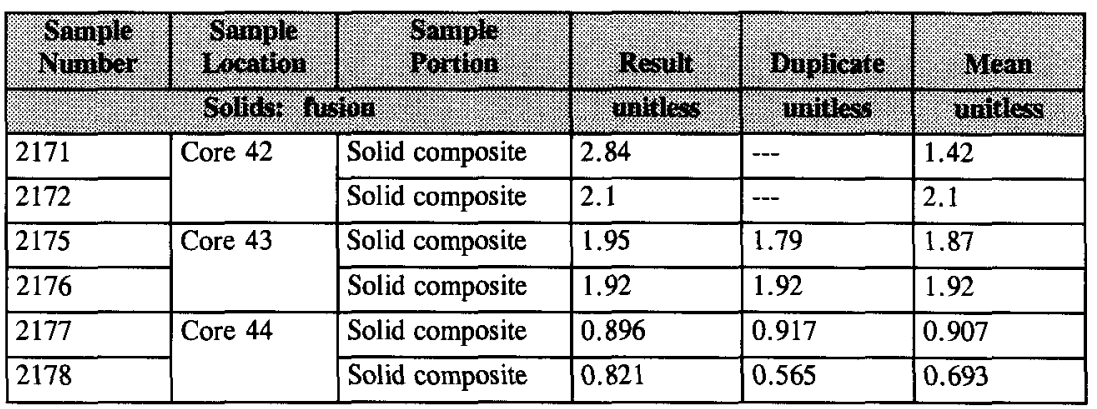


Table B2-82. Tank 241-S-104 Analytical Results: Total Beta (Alpha Radiation).

\begin{tabular}{|c|c|c|c|c|c|}
\hline 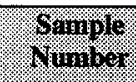 & ognosiso & oforis & Rerall: & Binglionis & yesi \\
\hline \multicolumn{3}{|c|}{ 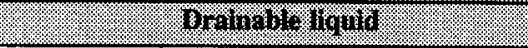 } & 16\% & 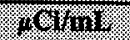 & 101114 \\
\hline 2247 & 42: 1 & Drainable liquid & 116 & & 116 \\
\hline 2249 & 43:1 & Drainable liquid & 127 & & 127 \\
\hline 2248 & $44: 1$ & Drainable liquid & 138 & & 138 \\
\hline
\end{tabular}

Table B2-83. Tank 241-S-104 Analytical Results: Total Beta.

\begin{tabular}{|c|c|c|c|c|c|}
\hline Womo & 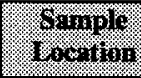 & . & 1resuly & OHollon & Hon \\
\hline \multicolumn{3}{|c|}{ 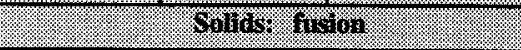 } & \% & \% & $10 \%$ \\
\hline 2171 & \multirow[t]{2}{*}{ Core 42} & Solid composite & 80.3 & 89.7 & 85 \\
\hline 2172 & & Solid composite & 94.8 & 102 & 98.4 \\
\hline 2175 & \multirow[t]{2}{*}{ Core 43} & Solid composite & 930 & 914 & 922 \\
\hline 2176 & & Solid composite & 985 & 986 & 985.5 \\
\hline 2177 & \multirow[t]{2}{*}{ Core 44} & Solid composite & 865 & 1,010 & 937.5 \\
\hline 2178 & & Solid composite & 795 & 846 & 820.5 \\
\hline
\end{tabular}

Table B2-84. Tank 241-S-104 Analytical Results: Ratio of Total Beta to Cesium + Strontium.

\begin{tabular}{|c|c|c|c|c|c|}
\hline 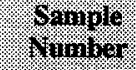 & Womou & 3ando & 10411 & Binal:erits. & Hisur \\
\hline \multicolumn{3}{|c|}{ \%or) $11 \%$} & Mait & 110\% ( & Inin \\
\hline 2171 & \multirow[t]{2}{*}{ Core 42} & Solid composite & 0.086 & 0.101 & 0.093 \\
\hline 2172 & & Solid composite & 0.089 & 0.105 & 0.0971 \\
\hline 2175 & \multirow[t]{2}{*}{ Core 43} & Solid composite & 0.97 & 0.969 & 0.9705 \\
\hline 2176 & & Solid composite & 1.02 & 0.927 & 0.974 \\
\hline 2177 & \multirow[t]{2}{*}{ Core 44} & Solid composite & 0.916 & 0.912 & 0.914 \\
\hline 2178 & & Solid composite & 0.915 & 0.884 & 0.90 \\
\hline
\end{tabular}


Table B2-85. Tank 241-S-104 Analytical Results: Percent Water (TGA). (2 sheets)

\begin{tabular}{|c|c|c|c|c|c|}
\hline $\begin{array}{l}9+110 \\
\ln \end{array}$ & 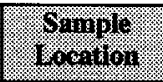 & 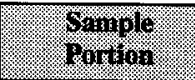 & $\ln 6111$ & (3)11\% & Hen. \\
\hline & 1.. & (3) & $\%$ & \% & $1 \%$ \\
\hline 2067 & $42: 1$ & Whole & 39.3 & 40.6 & 39.95 \\
\hline 2071 & $42: 2$ & Whole & 35.2 & 38.5 & 36.85 \\
\hline 2074 & $42: 3$ & Whole & 42 & 42.3 & 42.15 \\
\hline 2060 & $42: 4$ & \begin{tabular}{|l|} 
Whole \\
\end{tabular} & 23.8 & 21.6 & 22.7 \\
\hline 2077 & $42: 5$ & Whole & 29.4 & 29.5 & 29.45 \\
\hline 2083 & $42: 6$ & Whole & 30.32 & 20.9 & 25.61 \\
\hline \multirow[t]{2}{*}{2038} & \multirow[t]{2}{*}{ 43: 1} & Whole & 31.1 & 32 & 31.55 \\
\hline & & Whole & 43.4 & 42.9 & 43.15 \\
\hline 2046 & 43: 2 & Whole & 33.9 & 29.3 & 31.6 \\
\hline 2051 & 43: 3 & Whole & 53.8 & 52.4 & 53.1 \\
\hline \multirow[t]{2}{*}{2053} & \multirow[t]{2}{*}{$43: 4$} & Whole & 30.8 & & 30.8 \\
\hline & & Whole & & 30.3 & 30.3 \\
\hline 2056 & $43: 5$ & Whole & 26.4 & 26.3 & 26.35 \\
\hline 2059 & $43: 6$ & Whole & 22.9 & 17.99 & 20.445 \\
\hline 2030 & \multirow[t]{2}{*}{ 44: 1} & Whole & 29.7 & 36.2 & 32.95 \\
\hline 2033 & & Whole & 9.1 & 7.66 & 8.38 \\
\hline 2029 & $44: 2$ & Whole & 38.3 & 37.8 & 38.05 \\
\hline 2022 & \multirow[t]{2}{*}{$44: 3$} & Whole & 23.7 & 25.2 & 24.45 \\
\hline 2026 & & Whole & 30.4 & 37.7 & 34.05 \\
\hline 2023 & $44: 4$ & Whole & 35.2 & 36.2 & 35.7 \\
\hline 2015 & \multirow[t]{2}{*}{$44: 5$} & Whole & 25.3 & 31.6 & 28.45 \\
\hline 2017 & & Whole & 20.5 & 25.7 & 23.1 \\
\hline 2001 & $44: 6$ & Partial & 23.7 & 24.9 & 24.3 \\
\hline 2171 & \multirow[t]{2}{*}{ Core 42} & Solid composite & 23.9 & 25.5 & 24.7 \\
\hline 2172 & & Solid composite & 36 & 33.9 & 34.95 \\
\hline 2175 & \multirow[t]{2}{*}{ Core 43} & Solid composite & 29.4 & 28.6 & 29 \\
\hline 2176 & & Solid composite & 29.7 & 33.5 & 31.6 \\
\hline 2177 & \multirow[t]{2}{*}{ Core 44} & Solid composite & 95.24 & 94.93 & 95.085 \\
\hline 2178 & & Solid composite & 93.84 & 94.68 & 94.26 \\
\hline
\end{tabular}


Table B2-85. Tank 241-S-104 Analytical Results: Percent Water (TGA). (2 sheets)

\begin{tabular}{|c|c|c|c|c|c|}
\hline 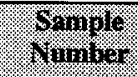 & 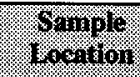 & \%ormong & gesing & $10401 \%=0$ & Hear \\
\hline \multicolumn{3}{|c|}{ 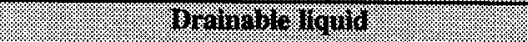 } & 6 & $1 \%$ & \% \\
\hline 2247 & $42: 1$ & Drainable liquid & 55.71 & 55.4 & 55.555 \\
\hline 2249 & 43: 1 & Drainable liquid & 54.29 & & 54.29 \\
\hline 2248 & $44: 1$ & Drainable liquid & 55.13 & & 55.13 \\
\hline
\end{tabular}

Table B2-86. Tank 241-S-104 Analytical Results: Percent Water (Percent Solids). (2 sheets)

\begin{tabular}{|c|c|c|c|c|c|}
\hline 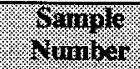 & . & Whyng & Resull & 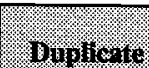 & Wena \\
\hline : & 9kilo & 3 & $\%$ & ;. 8 & \% \\
\hline 2116 & $42: 1$ & Whole & 43.5 & 43.4 & 43.45 \\
\hline 2118 & $42: 2$ & Whole & 45 & 50.1 & 47.55 \\
\hline 2120 & $42: 3$ & Whole & 42.8 & 43.3 & 43.05 \\
\hline 2122 & $42: 4$ & Whole & $4 \overline{3.3}$ & 34.5 & 38.9 \\
\hline 2125 & $42: 5$ & Whole & 31.6 & 29.6 & 30.6 \\
\hline 2127 & $42: 6$ & Whole & 27.1 & 30.6 & 28.85 \\
\hline 2129 & $43: 1$ & Whole & 44.8 & 44.2 & 44.5 \\
\hline 2131 & $43: 2$ & Whole & 41.3 & 41.6 & 41.45 \\
\hline 2134 & $43: 3$ & Whole & 42.3 & 41.6 & 41.95 \\
\hline 2136 & $43: 4$ & Whole & 34.9 & $36 . \overline{3}$ & 35.6 \\
\hline 2138 & $43: 5$ & Whole & 34.6 & 30.8 & 32.7 \\
\hline 2140 & $43: 6$ & Whole & 26.3 & 25.6 & 25.95 \\
\hline 2143 & $44: 1$ & Whole & 67 & 63.3 & 65.15 \\
\hline 2131 & $44: 2$ & Whole & 41.3 & 43.9 & 42.6 \\
\hline 2147 & $44: 3$ & Whole & 80.3 & 64.6 & $72.4 \overline{5}$ \\
\hline 2149 & $44: 4$ & Whole & 58.1 & 53.1 & 55.6 \\
\hline 2152 & $44: 5$ & Whole & 34.9 & 31.9 & 33.4 \\
\hline 2003 & $44: 6$ & Partial & 24.2 & 24.9 & 24.55 \\
\hline 2199 & \multirow[t]{2}{*}{ Core 42} & Solid composite & 36.2 & 34.9 & 35.55 \\
\hline 2201 & & Solid composite & 36.2 & 33.4 & 34.8 \\
\hline
\end{tabular}


Table B2-86. Tank 241-S-104 Analytical Results: Percent Water (Percent Solids). (2 sheets)

\begin{tabular}{|c|c|c|c|c|c|}
\hline $\begin{array}{l}\text { Spmole- } \\
\text { Nirniler. }\end{array}$ & Timpore & $\begin{array}{l}\text { Sariph } \\
\text { Eortion }\end{array}$ & ressin & Duplicare & (16ari \\
\hline 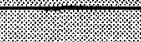 & \multicolumn{2}{|c|}{ 3\%11\% } & 8\%: & 8 & 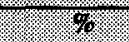 \\
\hline 2203 & \multirow[t]{2}{*}{ Core 43} & Solid composite & 28.5 & 30 & 29.25 \\
\hline 2205 & & Solid composite & 34.7 & 32.8 & 33.75 \\
\hline 2208 & \multirow[t]{2}{*}{ Core 44} & Solid composite & 37.1 & 35.5 & 36.3 \\
\hline 2210 & & Solid composite & 38.3 & 37.2 & 37.75 \\
\hline & \multicolumn{2}{|c|}{ S Braina } & $8 \%$ & 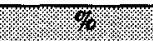 & 28 \\
\hline 2247 & $42: 1$ & Drainable liquid & 56.94 & & 56.94 \\
\hline 2248 & 43: 1 & Drainable liquid & 56.24 & & 56.24 \\
\hline 2249 & 44: 1 & Drainable liquid & 56.85 & & 56.85 \\
\hline
\end{tabular}

Table B2-87. Differential Scanning Calorimetry (DSC). (2 sheets)

\begin{tabular}{|c|c|c|c|c|}
\hline Sample & I. & Timple & 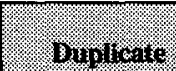 & (1) \\
\hline F2063 & 42: 1 & 0 & - & \\
\hline F2060 & 42.4 & 0 & $\cdots$ & \\
\hline F2067 & $42: 1$ & 0 & -- & \\
\hline F2071 & $42: 2$ & 0 & -- & \\
\hline F2074 & 42.3 & 0 & -- & \\
\hline F2085 & $42: 5$ & 0 & -- & \\
\hline F2077 & $42: 5$ & 0 & -- & \\
\hline F2083 & $42: 5$ & 0 & -- & \\
\hline F2169 & 42: Composite 1 & 0 & -- & \\
\hline $\mathrm{F} 2171$ & 42: Composite 1 & 0 & $-\cdots$ & \\
\hline $\mathrm{F} 2172$ & 42: Composite 2 & 0 & -- & \\
\hline F2064 & $43: 5$ & 0 & -- & \\
\hline F2051 & $43: 3$ & 0 & -- & \\
\hline F2053 & $43: 4$ & 0 & -- & \\
\hline F2056 & $43: 5$ & 0 & $\cdots$ & \\
\hline F2059 & $43: 6$ & 0 & $-\cdots$ & \\
\hline F2062 & $43: 5$ & 0 & -- & \\
\hline
\end{tabular}


HNF-SD-WM-ER-370 Rev. 1

Table B2-87. Differential Scanning Calorimetry (DSC). (2 sheets)

\begin{tabular}{|c|c|c|c|c|}
\hline Sample & 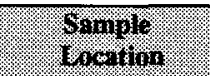 & $\begin{array}{l}\text { Saringle: } \\
\text { Resuls: }\end{array}$ & ( Gullicate & Wresn \\
\hline F2038 & 43: 1 & 0 & --- & \\
\hline F2039 & 43: 1 & 0 & --- & \\
\hline F2046 & $43: 2$ & 0 & $-\cdots$ & \\
\hline F2047 & $43: 5$ & 0 & --- & \\
\hline F2173 & 42: Composite 1 & 0 & --- & \\
\hline F2175 & 42: Composite 1 & 4.5 & 0 & \\
\hline F2176 & 43: Composite 2 & 0 & 0 & \\
\hline F2023 & C44S4 & 0 & 0 & 0 \\
\hline F2029 & C44S2 & 0 & 0 & \\
\hline F2030 & $\overline{\mathrm{C} 44 \mathrm{~S} 1}$ & 0 & --- & \\
\hline F2033 & $\mathrm{C} 44 \mathrm{~S} 1$ & 0 & --- & \\
\hline F2015 & C44S5 & 0 & 0 & 0 \\
\hline F2017 & C44S5 & 0 & $-\cdots$ & \\
\hline F2022 & C44S3 & 0 & --- & \\
\hline F2026 & C44S3 & 0 & 0 & 0 \\
\hline F2177 & C44 Composite 1 & 74.3 & 55.4 & \\
\hline F2178 & C44 Composite 1 & 32.5 & 27.5 & \\
\hline
\end{tabular}


Table B2-88. Tank 241-S-104 Analytical Results: pH Measurement.

\begin{tabular}{|c|c|c|c|c|c|}
\hline $\begin{array}{l}\text { Saingle } \\
\text { Number }\end{array}$ & $\begin{array}{l}\text { Siminglo } \\
\text { location }\end{array}$ & 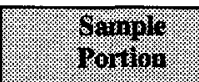 & nesury & Buplowitin & Mear. \\
\hline$(2$ & \multicolumn{2}{|c|}{ 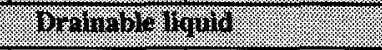 } & aminy & mintess: & mintaress \\
\hline 2247 & 42: 1 & Drainable liquid & 13.65 & & 13.65 \\
\hline 2248 & 43: 1 & Drainable liquid & 13.62 & & 13.62 \\
\hline 2249 & $44: 1$ & Drainable liquid & 13.1 & & 13.1 \\
\hline & \multicolumn{2}{|c|}{ Sildos: water digest } & 1riithess & Mimiss & orities \\
\hline 2171 & \multirow[t]{2}{*}{ Core 42} & Solid composite & 10.17 & 13.29 & 11.73 \\
\hline 2172 & & Solid composite & 13.32 & 13.38 & 13.35 \\
\hline 2175 & \multirow[t]{2}{*}{ Core 43} & Solid composite & 12.91 & 12.63 & 12.77 \\
\hline 2176 & & Solid composite & 13.08 & 13.09 & 13.085 \\
\hline 2177 & \multirow[t]{2}{*}{ Core 44} & Solid composite & 13.13 & 13.15 & 13.14 \\
\hline 2178 & & \begin{tabular}{|l} 
Solid composite \\
\end{tabular} & 13.07 & 13.09 & 13.08 \\
\hline
\end{tabular}

Table B2-89. Tank 241-S-104 Analytical Results: Total Organic Carbon (Furnace Oxidation).

\begin{tabular}{|c|c|c|c|c|c|}
\hline $\begin{array}{l}\text { Sample } \\
\text { Tuniber }\end{array}$ & Sarnplo & $\begin{array}{l}\text { Somple } \\
\text { rorting }\end{array}$ & resiln & 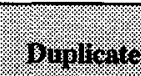 & 1.8. \\
\hline \multicolumn{3}{|c|}{ 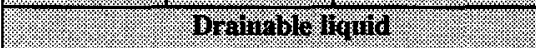 } & 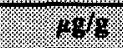 & 1489 & 1084 \\
\hline 2247 & $42: 1$ & Drainable liquid & 529 & & $529^{\text {QC:f }}$ \\
\hline 2249 & $43: 1$ & \begin{tabular}{|l|} 
Drainable liquid \\
\end{tabular} & 469 & 73.4 & $271^{\text {QC:f }}$ \\
\hline 2248 & $44: 1$ & Drainable liquid & 404 & 73.4 & $239^{\mathrm{OC}: \mathrm{f}}$ \\
\hline
\end{tabular}


Table B2-90. Tank 241-S-104 Analytical Results: Total Organic Carbon (Furnace Oxidation).

\begin{tabular}{|c|c|c|c|c|c|}
\hline $\begin{array}{l}\text { Simpile } \\
\text { Trmiber }\end{array}$ & $\begin{array}{l}\text { Sample } \\
\text { Location }\end{array}$ & $\begin{array}{l}\text { Sampl: } \\
\text { Porriun }\end{array}$ & Reswill & Bullionis & Yean \\
\hline 8 & \multicolumn{2}{|c|}{ 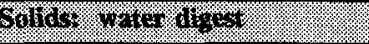 } & 488 & 488 & Hos \\
\hline 2171 & \multirow[t]{2}{*}{ Core 42} & Solid composite & 2,190 & 2,380 & 2,285 \\
\hline 2172 & & Solid composite & 1,300 & 1,300 & 1,300 \\
\hline 2175 & \multirow[t]{2}{*}{ Core 43} & Solid composite & 2,350 & 2,060 & 2,205 \\
\hline 2176 & & Solid composite & 1,190 & 1,090 & 1,140 \\
\hline 2177 & \multirow[t]{2}{*}{ Core 44} & Solid composite & $<1,100$ & $<1,100$ & $<1,100$ \\
\hline 2178 & & Solid composite & $<1,100$ & $<1,100$ & $<1,100$ \\
\hline
\end{tabular}

Table B2-91. Tank 241-S-104 Analytical Results: Specific Gravity.

\begin{tabular}{|c|c|c|c|c|c|}
\hline $\begin{array}{l}\text { Sample } \\
\text { Rumber }\end{array}$ & $\begin{array}{l}\text { Sormplo } \\
\text { Socation }\end{array}$ & $\begin{array}{l}\text { Shample } \\
\text { Tomilow }\end{array}$ & 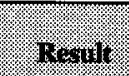 & Buplisate & Mrean \\
\hline \multicolumn{3}{|c|}{ 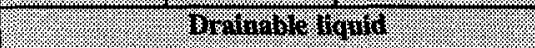 } & Tritles: & mintiver & Minitieso \\
\hline 2247 & 42: 1 & Drainable liquid & 1.36 & & $1.36^{\mathrm{QC:f}}$ \\
\hline 2249 & 43: 1 & Drainable liquid & 1.39 & & $1.39^{\mathrm{QC}: \mathrm{f}}$ \\
\hline 2248 & 44: 1 & Drainable liquid & 1.36 & & $1.36^{\mathrm{eC}: \mathrm{f}}$ \\
\hline
\end{tabular}

Table B2-92. Tank 241-S-104 Analytical Results: Centrifuged Solids Density.

\begin{tabular}{|c|c|c|c|c|}
\hline $\begin{array}{l}\text { Sample } \\
\text { Simmber }\end{array}$ & $\begin{array}{l}\text { Sample } \\
\text { Socotion }\end{array}$ & $\begin{array}{l}\text { Semple } \\
\text { fortion }\end{array}$ & nitsin & Irean \\
\hline : & Solios & 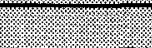 & . $8 \mathrm{rm}$ & $4 \mathrm{mi}$ \\
\hline $93-01072$ & $42: 2$ & Whole & 1.71 & 1.71 \\
\hline
\end{tabular}

Table B2-93. Tank 241-S-104 Analytical Results: Centrifuged Supernatant Density.

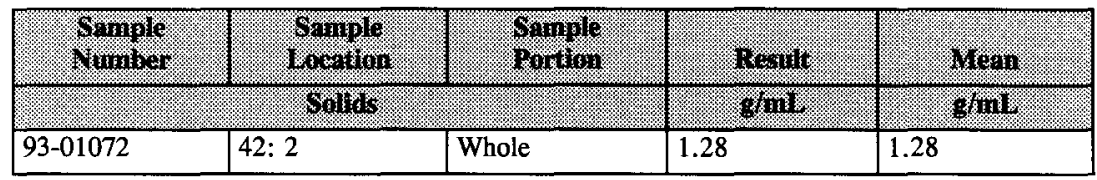


Table B2-94. Tank 241-S-104 Analytical Results: Density.

\begin{tabular}{|c|c|c|c|c|}
\hline $\begin{array}{l}\text { Somplat } \\
\text { Ninnber }\end{array}$ & Samplo & $\begin{array}{l}\text { Oample } \\
\text { Yorsion }\end{array}$ & resint: & Mean \\
\hline l. & Solics. & & $8 \mathrm{mi}$ & gint \\
\hline $93-01072$ & $42: 2$ & Whole & 1.64 & 1.64 \\
\hline
\end{tabular}

Table B2-95. Tank 241-S-104 Analytical Results: Settled Solids.

\begin{tabular}{|c|c|c|c|c|}
\hline $\begin{array}{l}\text { Sample: } \\
\text { Sumber }\end{array}$ & $\begin{array}{l}\text { Simple: } \\
\text { ecention }\end{array}$ & $\begin{array}{l}\text { Sanple } \\
\text { Partion }\end{array}$ & Resulu & 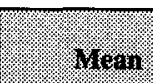 \\
\hline (17. & Golors & 18 & 3. & 17. \\
\hline $93-01072$ & $42: 2$ & Whole & 100 & 100 \\
\hline $93-01753$ & $42: 4$ & Whole & 100 & 100 \\
\hline
\end{tabular}

Table B2-96. Tank 241-S-104 Analytical Results: Volume Percent Centrifuged Solids.

\begin{tabular}{|c|c|c|c|c|}
\hline $\begin{array}{l}\text { Sininglo: } \\
\text { Number. }\end{array}$ & $\begin{array}{l}\text { Sirimgle } \\
\text { Lesition }\end{array}$ & $\begin{array}{l}\text { Siringle } \\
\text { Poritos }\end{array}$ & Resuly & Yrenn \\
\hline (2) & Sollos & 2 & 8 & 98 \\
\hline 93-01072 & 42: 2 & Whole & 82.5 & 82.5 \\
\hline $93-01753$ & $42: 4$ & Whole & 100 & 100 \\
\hline
\end{tabular}

Table 82-97. Tank 241-S-104 Analytical Results: Weight Percent Centrifuged Solids.

\begin{tabular}{|c|c|c|c|c|}
\hline $\begin{array}{l}\text { Sample } \\
\text { Timber }\end{array}$ & $\begin{array}{l}\text { Sample: } \\
\text { Eractian }\end{array}$ & $\begin{array}{l}\text { Surnoly } \\
\text { fontion }\end{array}$ & 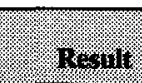 & Mean \\
\hline ? & Solits & স & 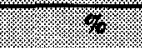 & \% \\
\hline $93-01072$ & $42: 2$ & Whole & 86.1 & 86.1 \\
\hline $93-01753$ & $42: 4$ & Whole & 100 & 100 \\
\hline
\end{tabular}


Table B2-98. Tank 241-S-104 Analytical Results: Weight Percent Solids.

\begin{tabular}{|c|c|c|c|c|}
\hline Whing & (6) & 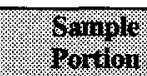 & 10sanl & Weail \\
\hline & oorig & y & \% & 14. \\
\hline 93-01072 & 42: 2 & Whole & 62.3 & 62.3 \\
\hline $93-01753$ & $42: 4$ & Whole & 67.7 & 67.7 \\
\hline
\end{tabular}

Table B2-99. Tank 241-S-104 Analytical Results: Weight Percent Undissolved Solids.

\begin{tabular}{|c|c|c|c|c|}
\hline 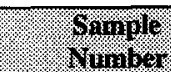 & 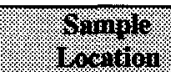 & \% 60 & (2) resil & Wha \\
\hline 4 & Sowios & & 9 & 18 \\
\hline 93-01072 & $42: 2$ & Whole & 55.4 & 55.4 \\
\hline
\end{tabular}

Table B2-100. Tank 241-S-104 Analytical Results: Extractible Organic Halides.

\begin{tabular}{|c|c|c|c|c|c|}
\hline WMing & $4 \%$ & 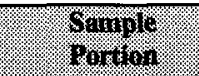 & igestin & Diplicisic. & 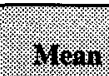 \\
\hline \multicolumn{3}{|c|}{ \$.01\% $1 \%$} & 48 & 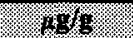 & 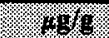 \\
\hline 93-01076-F1 & \multirow[t]{2}{*}{ Core 42} & Solid composite & $<10$ & $<10$ & $<10$ \\
\hline $93-01756-\mathrm{F} 1$ & & Solid composite & $<10$ & $<10$ & $<10$ \\
\hline $93-01757-\mathrm{F} 1$ & \multirow[t]{2}{*}{ Core 43} & Solid composite & $<10$ & $<10$ & $<10^{\mathrm{QC:f}}$ \\
\hline $93-01758-\mathrm{F} 1$ & & Solid composite & 11 & $<10$ & $<10.5$ \\
\hline 93-01759-F1 & \multirow[t]{2}{*}{ Core 44} & Solid composite & 30 & 30 & $30^{\mathrm{QC}: \mathrm{f}}$ \\
\hline $93-01760-\mathrm{F} 1$ & & Solid composite & $<10$ & $<10$ & $<10$ \\
\hline
\end{tabular}


Table B2-101. Tank 241-S-104 Analytical Data: Volatile Organic Analyses.

\begin{tabular}{|c|c|c|c|}
\hline 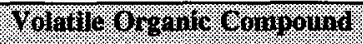 & $341 \% 119$ & 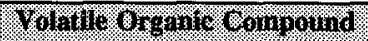 & Mrsili 69 \\
\hline Chloromethane & $\mathrm{n} / \mathrm{d}$ & 1,2-Dichloropropane & $\mathrm{n} / \mathrm{d}$ \\
\hline Bromomethane & $\mathrm{n} / \mathrm{d}$ & cis-1,3-Dichloropropene & $\mathrm{n} / \mathrm{d}$ \\
\hline Vinyl chloride & $\mathrm{n} / \mathrm{d}$ & Trichloroethene & $\mathrm{n} / \mathrm{d}$ \\
\hline Chloroethane & $\mathrm{n} / \mathrm{d}$ & Dibromochloromethane & $\mathrm{n} / \mathrm{d}$ \\
\hline Methylene chloride & $\mathrm{n} / \mathrm{d}$ & 1,1,2-Trichloroethane & $\mathrm{n} / \mathrm{d}$ \\
\hline Acetone & $\mathrm{n} / \mathrm{d}$ & Benzene & $\mathrm{n} / \mathrm{d}$ \\
\hline Carbon disulfide & $\mathrm{n} / \mathrm{d}$ & trans-1,3-Dichloropropene & $\mathrm{n} / \mathrm{d}$ \\
\hline 1,1-Dichloroethene & $\mathrm{n} / \mathrm{d}$ & Bromoform & $\mathrm{n} / \mathrm{d}$ \\
\hline 1,1-Dichloroethane & $\mathrm{n} / \mathrm{d}$ & 4-Methyl-2-Pentanone & $\mathrm{n} / \mathrm{d}$ \\
\hline 1,2-Dichloroethene (total) & $\mathrm{n} / \mathrm{d}$ & 2-Hexanone & $\mathrm{n} / \mathrm{d}$ \\
\hline Chloroform & $n / d$ & Tetrachloroethene & $\mathrm{n} / \mathrm{d}$ \\
\hline 1,2-Dichloroethane & $\mathrm{n} / \mathrm{d}$ & 1,1,2,2-Tetrachloroethane & $\mathrm{n} / \mathrm{d}$ \\
\hline 2-Butanone & $\mathrm{n} / \mathrm{d}$ & Toluene & $\mathrm{n} / \mathrm{d}$ \\
\hline 1,1,1-Trichloroethane & $\mathrm{n} / \mathrm{d}$ & Chlorobenzene & $\mathrm{n} / \mathrm{d}$ \\
\hline Carbon tetrachloride & $\mathrm{n} / \mathrm{d}$ & Ethylbenzene & $\mathrm{n} / \mathrm{d}$ \\
\hline Vinyl acetate & $\mathrm{n} / \mathrm{d}$ & Styrene & $\mathrm{n} / \mathrm{d}$ \\
\hline Bromodichloromethane & $\mathrm{n} / \mathrm{d}$ & Xylene (total) & $\mathrm{n} / \mathrm{d}$ \\
\hline
\end{tabular}

Note:

$\mathrm{n} / \mathrm{d}=$ not detected 
HNF-SD-WM-ER-370 Rev. 1

Table B2-102. Tank 241-S-104 Analytical Results: Dodecane (VOA).

\begin{tabular}{|c|c|c|c|c|}
\hline $\begin{array}{l}\text { Sumple } \\
\text { Nimmier }\end{array}$ & $\begin{array}{l}\text { Shmplo } \\
\text { I racen }\end{array}$ & $\begin{array}{l}\text { Samplo } \\
\text { Portion }\end{array}$ & mosini & Mean \\
\hline א. & Tollas & 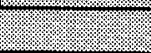 & $186 \%$ & $148 \%$ \\
\hline 93-01070-M1 & 43: 6 & Whole & 2.8 & 2.8 \\
\hline
\end{tabular}

Note:

$\mathrm{VOA}=\quad$ volatile organic analysis

Table B2-103. Tank 241-S-104 Analytical Results: Hexamethyl Disiloxane (VOA).

\begin{tabular}{|c|c|c|c|c|}
\hline Ginimis & 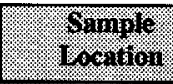 & $\begin{array}{l}\text { Sarople: } \\
\text { Rombion }\end{array}$ & Resilit & Heras \\
\hline (3) & Gollos & : & $16 \%$ & $148 \%$ \\
\hline 93-01071-M1 & $42: 1$ & Whole & 1,200 & 1,200 \\
\hline \begin{tabular}{|c|}
$93-01073-\mathrm{M} 1$ \\
\end{tabular} & $42: 3$ & Whole & 2,900 & 2,900 \\
\hline 93-01074-M1 & $42: 5$ & Whole & 190 & 190 \\
\hline 93-01750-M1 & 43: 1 & Whole & 450 & 450 \\
\hline 93-01751-M1 & $43: 2$ & Whole & 420 & 420 \\
\hline 93-01068-M1 & $43: 3$ & Whole & 440 & 440 \\
\hline 93-01752-M1 & $43: 4$ & Whole & 530 & 530 \\
\hline 93-01069-M1 & $43: 5$ & Whole & 560 & 560 \\
\hline 93-01070-M1 & $43: 6$ & Whole & 400 & 400 \\
\hline 93-01067-M1 & $44: 1$ & Whole & 540 & 540 \\
\hline 93-01066-M1 & $44: 2$ & Whole & 220 & 220 \\
\hline 93-01065-M1 & $44: 3$ & Whole & 74 & 74 \\
\hline 93-01064-M1 & $44: 5$ & Whole & 110 & 110 \\
\hline 93-01815-M1 & 44: 6 & Partial & 540 & 540 \\
\hline
\end{tabular}


HNF-SD-WM-ER-370 Rev. 1

Table B2-104. Tank 241-S-104 Analytical Results: Methoxytrimethyl Silane (VOA).

\begin{tabular}{|c|c|c|c|c|c|}
\hline $\begin{array}{l}\text { Sample } \\
\text { ringlos }\end{array}$ & 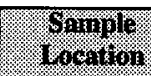 & Shinile & Rising & Diplicuse & Meran \\
\hline (1) & 60110 & l: & $148 \%$ & 1488 & $3 \%$ \\
\hline 93-01071-M1 & 42:1 & Whole & 1,900 & & 1,900 \\
\hline 93-01073-M1 & $42: 3$ & Whole & 1,400 & & 1,400 \\
\hline 93-01074-M1 & $42: 5$ & Whole & 650 & & 650 \\
\hline 93-01750-M1 & 43: 1 & Whole & 600 & & 600 \\
\hline 93-01751-M1 & $43: 2$ & Whole & 320 & & 320 \\
\hline 93-01068-M1 & 43: 3 & Whole & 370 & & 370 \\
\hline 93-01752-M1 & 43: 4 & Whole & 720 & & 720 \\
\hline 93-01069-M1 & $43: 5$ & Whole & 380 & & 380 \\
\hline 93-01070-M1 & 43: 6 & Whole & 540 & & 540 \\
\hline 93-01067-M1 & $44: 1$ & Whole & 88 & & 88 \\
\hline 93-01066-M1 & $44: 2$ & Whole & 65 & & 65 \\
\hline 93-01065-M1 & $44: 3$ & Whole & 31 & & 31 \\
\hline 93-01064-M1 & $44: 5$ & Whole & $\overline{92}$ & & 92 \\
\hline 93-01815-M1 & $44: 6$ & Partial & 88 & & 88 \\
\hline
\end{tabular}

Table B2-105. Tank 241-S-104 Analytical Results: Trimethyl Silanol (VOA).

\begin{tabular}{|c|c|c|c|c|c|}
\hline $\begin{array}{l}\text { Sample: } \\
\text { Ninmber: }\end{array}$ & 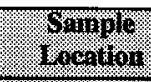 & $\begin{array}{l}\text { Swingle } \\
\text { Sinot on }\end{array}$ & 128.8011 & Dipolicate & Mean \\
\hline (2) & Sol19\% & (2) & 48 & .968 & 496 \\
\hline 93-01071-M1 & $42: 1$ & Whole & 1,600 & & 1,600 \\
\hline 93-01073-M1 & $42: 3$ & Whole & 2,400 & & 2,400 \\
\hline 93-01074-M1 & $42: 5$ & Whole & 110 & & 110 \\
\hline 93-01750-M1 & 43: 1 & Whole & 900 & & 900 \\
\hline 93-01751-M1 & $43: 2$ & Whole & 1,000 & & 1,000 \\
\hline 93-01068-M1 & $43: 3$ & Whole & 1,000 & & 1,000 \\
\hline 93-01752-M1 & $43: 4$ & Whole & 810 & & 810 \\
\hline 93-01069-M1 & $43: 5$ & Whole & 400 & & 400 \\
\hline 93-01070-M1 & $43: 6$ & Whole & 550 & & 550 \\
\hline 93-01067-M1 & 44: 1 & Whole & 290 & & 290 \\
\hline 93-01066-M1 & $44: 2$ & Whole & 200 & & 200 \\
\hline 93-01065-M1 & $44: 3$ & Whole & 92 & & 92 \\
\hline 93-01064-M1 & $44: 5$ & Whole & 120 & & 120 \\
\hline 93-01815-M1 & $44: 6$ & Partial & 290 & & 290 \\
\hline
\end{tabular}


Table B2-106. Tank 241-S-104 Analytical Data: Semivolatile Organic Analyses (SVOA).

\begin{tabular}{|c|c|c|c|}
\hline 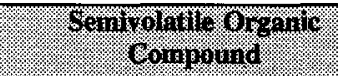 & $\frac{18}{86}$ & (.) & $\frac{9}{4}+4$ \\
\hline Phenol & $\mathrm{n} / \mathrm{d}$ & 2,6-Dinitrotoluene & $\mathrm{n} / \mathrm{d}$ \\
\hline bis(2-Chloroethyl)ether & $\mathrm{n} / \mathrm{d}$ & 3-Nitroaniline & $\mathrm{n} / \mathrm{d}$ \\
\hline 2-Chlorophenol & $\mathrm{n} / \mathrm{d}$ & Acenaphthene & $\mathrm{n} / \mathrm{d}$ \\
\hline 1,3-Dichlorobenzene & $\mathrm{n} / \mathrm{d}$ & 2,4-Dinitrophenol & $n / d$ \\
\hline 1,4-Dichlorobenzene & $\mathrm{n} / \mathrm{d}$ & 4-Nitrophenol & $\mathrm{n} / \mathrm{d}$ \\
\hline Benzyl alcohol & $\mathrm{n} / \mathrm{d}$ & Dibenzofuran & $\mathrm{n} / \mathrm{d}$ \\
\hline 1,2-Dichlorobenzene & $\mathrm{n} / \mathrm{d}$ & 2,4-Dinitrotoluene & $\mathrm{n} / \mathrm{d}$ \\
\hline 2-Methylphenol & $\mathrm{n} / \mathrm{d}$ & Diethylphthalate & $\mathrm{n} / \mathrm{d}$ \\
\hline bis(2-Chloroisopropyl)ether & $\mathrm{n} / \mathrm{d}$ & 4-Chlorophenyl-phenylether & $\mathrm{n} / \mathrm{d}$ \\
\hline 4-Methylphenol & $\mathrm{n} / \mathrm{d}$ & Fluorene & $\mathrm{n} / \mathrm{d}$ \\
\hline N-Nitroso-di-n-propylamine & $\mathrm{n} / \mathrm{d}$ & 4-Nitroanaline & $\mathrm{n} / \mathrm{d}$ \\
\hline Hexachloroethane & $\mathrm{n} / \mathrm{d}$ & 4,6-Dinitro-2-methylphenol & $\mathrm{n} / \mathrm{d}$ \\
\hline Nitrobenzene & $\mathrm{n} / \mathrm{d}$ & N-Nitrosodiphenylamine & $\mathrm{n} / \mathrm{d}$ \\
\hline Isophorone & $\mathrm{n} / \mathrm{d}$ & 4-Bromophenyl-phenylether & $\mathrm{n} / \mathrm{d}$ \\
\hline 2-Nitrophenol & $\mathrm{n} / \mathrm{d}$ & Hexachlorobenzene & $\mathrm{n} / \mathrm{d}$ \\
\hline 2,4-Dimethylphenol & $\mathrm{n} / \mathrm{d}$ & Pentachlorophenol & $\bar{n} / \mathrm{d}$ \\
\hline Benzoic acid & $\mathrm{n} / \mathrm{d}$ & Phenanthrene & $\mathrm{n} / \mathrm{d}$ \\
\hline bis(2-Chloroethoxy)methane & $\mathrm{n} / \mathrm{d}$ & Anthracene & $\mathrm{n} / \mathrm{d}$ \\
\hline 2,4-Dichlorophenol & $\mathrm{n} / \mathrm{d}$ & Di-n-butylphthalate & $\mathrm{n} / \mathrm{d}$ \\
\hline 1,2,4-Trichlorobenzene & $\mathrm{n} / \mathrm{d}$ & Fluoranthene & $\mathrm{n} / \mathrm{d}$ \\
\hline Naphthalene & $\mathrm{n} / \mathrm{d}$ & Pyrene & $\mathrm{n} / \mathrm{d}$ \\
\hline 4-Chloroaniline & $\mathrm{n} / \mathrm{d}$ & Butylbenzylphthalate & $\mathrm{n} / \mathrm{d}$ \\
\hline Hexachlorobutadiene & $\mathrm{n} / \mathrm{d}$ & 3,3'-Dichlorobenzidine & $\mathrm{n} / \mathrm{d}$ \\
\hline 4-Chloro-3-methylphenol & $\mathrm{n} / \mathrm{d}$ & Benzo(a)anthracene & $\mathrm{n} / \mathrm{d}$ \\
\hline 2-Methylnaphthalene & $\mathrm{n} / \mathrm{d}$ & Chrysene & $n / d$ \\
\hline Hexachlorocyclopentadiene & $\mathrm{n} / \mathrm{d}$ & Bis(2-Ethylhexyl)phthalate & $\mathrm{n} / \mathrm{d}$ \\
\hline $2,4,6$-Trichlorophenol & $\mathrm{n} / \mathrm{d}$ & Benzo(b)fluoranthene & $\mathrm{n} / \mathrm{d}$ \\
\hline 2,4,5-Trichlorophenol & $\mathrm{n} / \mathrm{d}$ & Benzo(k)fluoranthene & $\mathrm{n} / \mathrm{d}$ \\
\hline 2-Chloronaphthalene & $\mathrm{n} / \mathrm{d}$ & Benzo(a)pyrene & $\mathrm{n} / \mathrm{d}$ \\
\hline 2-Nitroaniline & $\mathrm{n} / \mathrm{d}$ & Indeno(1,2,3-cd)pyrene & $\mathrm{n} / \mathrm{d}$ \\
\hline Dimethylphthalate & $\mathrm{n} / \mathrm{d}$ & Dibenz(a,h)anthracene & $\mathrm{n} / \mathrm{d}$ \\
\hline Acenaphthylene & $\mathrm{n} / \mathrm{d}$ & Benzo(g,h,i)perylene & $\mathrm{n} / \mathrm{d}$ \\
\hline
\end{tabular}


HNF-SD-WM-ER-370 Rev. 1

Table B2-107. Tank 241-S-104 Analytical Results: Dodecane (SVOA).

\begin{tabular}{|c|c|c|c|c|c|}
\hline 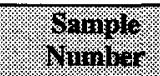 & (3) & . & Als,ill & Uoplisale & 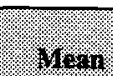 \\
\hline & Soris & . & 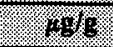 & 498 & $4 \%$ \\
\hline 93-01076-E1 & \multirow[t]{2}{*}{ Core 42} & Solid composite & 170 & & 170 \\
\hline 93-01756-E1 & & Solid composite & 170 & & 170 \\
\hline 93-01757-E1 & \multirow[t]{2}{*}{ Core 43} & Solid composite & 230 & & 230 \\
\hline 93-01758-E1 & & Solid composite & 33 & & 33 \\
\hline 93-01759-E1 & \multirow[t]{2}{*}{ Core 44} & Solid composite & 14 & & 14 \\
\hline 93-01760-E1 & & Solid composite & 12 & & 12 \\
\hline
\end{tabular}

Note:

SVOA $=\quad$ semivolatile organic analysis

Table B2-108. Tank 241-S-104 Analytical Results: Pentadecane (SVOA).

\begin{tabular}{|c|c|c|c|c|c|}
\hline Wan & $8 \% 96101$ & 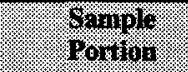 & Result & Buplitarto & 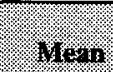 \\
\hline & wollis & & 1698 & 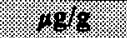 & 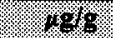 \\
\hline 93-01076-E1 & \multirow[t]{2}{*}{ Core 42} & Solid composite & 15 & & 15 \\
\hline 93-01756-E1 & & Solid composite & 14 & & 14 \\
\hline 93-01757-E1 & Core 43 & Solid composite & 24 & & 24 \\
\hline
\end{tabular}

Table B2-109. Tank 241-S-104 Analytical Results: Tetradecane (SVOA).

\begin{tabular}{|c|c|c|c|c|c|}
\hline . & 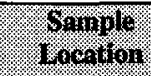 & . & ingitit & Suplisate & $x_{1}=n$ \\
\hline ?. & . Worth & & oros & 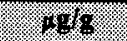 & 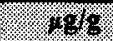 \\
\hline 93-01076-E1 & \multirow[t]{2}{*}{ Core 42} & Solid composite & 410 & & 410 \\
\hline $93-01756-\mathrm{E} 1$ & & Solid composite & 390 & & 390 \\
\hline 93-01757-E1 & \multirow[t]{2}{*}{ Core 43} & Solid composite & 670 & & 670 \\
\hline 93-01758-E1 & & Solid composite & 110 & & 110 \\
\hline 93-01759-E1 & \multirow[t]{2}{*}{ Core 44} & Solid composite & 49 & & 49 \\
\hline 93-01760-E1 & & Solid composite & 42 & & 42 \\
\hline
\end{tabular}


Table B2-110. Tank 241-S-104 Analytical Results: Tridecane (SVOA).

\begin{tabular}{|c|c|c|c|c|c|}
\hline $\begin{array}{l}\text { Simple. } \\
\text { fumber. }\end{array}$ & $\begin{array}{l}\text { Saringle } \\
\text { Encation }\end{array}$ & $\begin{array}{l}\text { Simplir } \\
\text { Yontion. }\end{array}$ & Result & Oinpligerse & Mison \\
\hline l. & Sollids & 1. & $18 \mathrm{~g} \mathrm{~g}$ & 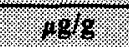 & $148 \%$ \\
\hline 93-01076-E1 & \multirow[t]{2}{*}{ Core 42} & Solid composite & 510 & & 510 \\
\hline 93-01756-E1 & & Solid composite & 500 & & 500 \\
\hline 93-01757-E1 & \multirow[t]{2}{*}{ Core 43} & Solid composite & 810 & & 810 \\
\hline 93-01758-E1 & & Solid composite & 130 & & 130 \\
\hline 93-01759-E1 & \multirow[t]{2}{*}{ Core 44} & Solid composite & 58 & & 58 \\
\hline 93-01760-E1 & & Solid composite & $\overline{49}$ & & 49 \\
\hline
\end{tabular}

\section{B3.0 ASSESSMENT OF CHARACTERIZATION RESULTS}

The purpose of this chapter is to discuss the overall quality and consistency of the current sampling results for tank $241-\mathrm{S}-104$, and to present the results of the calculation of an analytical-based inventory.

This section also evaluates sampling and analysis factors that may impact interpretation of the data. These factors are used to assess the overall quality and consistency of the data and to identify limitations in the use of the data.

\section{B3.1 FIELD OBSERVATIONS}

The samples obtained from core sampling activities in tank 241-S-104 were a mixture of air, liquids, and solids. After the sample was extruded from the sampler, photographs were taken of the sample with appropriate jar numbers and a color comparator chart shown in the same photograph. Visual characteristics of extruded samples were recorded in the appropriate log book, and careful attention was paid to sample volume, liquid/solid ratio, color, consistency, and homogeneity.

No problems were noted during the sampling event that would impact the analytical results. Recoveries were good for all segments, although segment $6 \mathrm{R}$ of core 42 , segment 6 of core 43, and segment 5 of core 44 had 10 percent, 33 percent, and 33 percent recoveries, respectively. 


\section{B3.2 QUALITY CONTROL ASSESSMENT}

Systematic error estimates are determined from the analysis of reference standards or spike recoveries. Laboratory control standards are used to estimate the accuracy of the analytical method, and are analyzed in conjunction with the duplicate samples. The laboratory measurement control system has set a quality control criterion under which no laboratory control standard may be run in conjunction with an analytical sample larger than three times the historical results. Matrix spikes are used to estimate the bias of the analytical method caused by matrix interferences. Spike samples are prepared by splitting a sample into two aliquots and adding a known amount of a particular analyte to one aliquot to calculate a percent recovery. The quality control criterion for spikes is $100+25$ percent recovery (Winters et al. 1990). Matrix spikes are not always applicable to analytes at high concentrations $(>1,000 \mu \mathrm{g} / \mathrm{g})$

About half of the analytes analyzed had one or more spikes that were outside the $100+25$ percent recovery limits. Aluminum, sodium, and technetium-299 had all three spikes outside the prescribed limits, while most of the others had just one of three outside the limits. Several of these elements were metals found in relatively high concentrations in the tank. Spike failures for major elements in general are frequently caused by a high element concentration in the sample. When the added spike concentration is insignificant compared to the concentration present in the sample, a failure usually occurs. Also, the standard results for potassium, sodium, and uranium exceeded the criteria of three times the historical results.

\section{B3.3 DATA VALIDATION FINDINGS}

The primary objective of data validation is to ensure the usability and defensibility of the data produced for the tank. This was accomplished through a detailed examination of the data package that attempted to verify that proper and acceptable analytical techniques had been applied. Evaluations such as instrument calibration checks, matrix spikes, duplicates, and blank analyses were reviewed, and the corresponding results were compared to relevant quality control criteria. Additionally, the data package was checked for the correct submission of required deliverables, correct transcription of raw data to the summary forms, and proper calculation of a number of parameters. Data that failed to satisfy the established quality objectives were qualified as reported in WHC (1993).

\section{B3.4 DATA CONSISTENCY CHECKS}

Comparisons of different analytical methods can help to assess the consistency and quality of the data. Several comparisons were possible with the data set provided by the three core samples, including a comparison of sulfur as analyzed by ICP with sulfate as analyzed by IC, 
and a comparison of total alpha activity and total beta activity with the sum of their individual emitters. In addition, mass and charge balances were calculated to help assess the overall data consistency.

\section{B3.4.1 Comparison of Results from Different Analytical Methods}

The following data consistency checks compare the results from two different analytical methods. Close comparison between the two methods strengthens the credibility of both results, whereas a poor correlation brings the reliability of the data into question. All analytical mean results were taken from tables in Section B2.0.

The analytical sulfur mean result as determined by ICP was $472 \mu \mathrm{g} / \mathrm{g}$, which converts to $1,420 \mu \mathrm{g} / \mathrm{g}$ of sulfate. The IC sulfate mean result was $2,270 \mu \mathrm{g} / \mathrm{g}$. The relative percent difference between these two sulfate results was 46 percent. This difference may be caused by the sulfur being low and near detection limits.

A comparison was made between the sums of the gross beta and gross alpha activities with the sums of the activities of the individual beta and alpha emitters. The activities of the individual beta emitters were summed according to the following equation:

$$
\text { Total beta }=1.42\left(2 *{ }^{90} \mathrm{Sr}\right)+1.51\left({ }^{137} \mathrm{Cs}\right) \text {. }
$$

(The coefficients 1.42 and 1.51 account for the detector efficiencies calibrated to ${ }^{60} \mathrm{Co}$.)

The activities of the individual alpha emitters were summed according to:

$$
\text { Total alpha }={ }^{239 / 240} \mathrm{Pu}+{ }^{241} \mathrm{Am} \text {. }
$$

The comparisons are given in Tables B3-1 and B3-2. The values for the individual cores in Table B3-1 are the means of the solid sample and duplicate solid sample results. The values for the liquid column in Table B3-2 are the means of all liquid sample results. As can be seen in Table B3-1, the individual beta and gross beta activities agree closely with the exception of those for the core 42 solid samples.

A comparison was made between the individual alpha emitters and the total alpha activity to determine the level of data consistency (Table B3-2). The sum of the individual alpha activity was $0.40 \mu \mathrm{Ci} / \mathrm{g}$ and the gross alpha sample result was $0.62 \mu \mathrm{Ci} / \mathrm{g}$. The individual alpha activity results are less than the total alpha results. This difference may have been the result of the total alpha counting instrumentation problem that caused high total alpha results when high beta activities were present. This problem has been corrected. 
Table B3-1. Tank 241-S-104 Comparison of Gross Beta Activities with the Total of the Individual Activities.

\begin{tabular}{|c|c|c|c|c|}
\hline (1) : warte. & 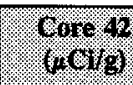 & 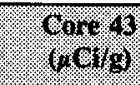 & 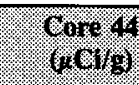 & 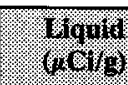 \\
\hline${ }^{90} \mathrm{Sr}$ & 306 & 316 & 308 & 0.0052 \\
\hline${ }^{137} \mathrm{Cs}$ & 64.5 & 58.7 & 63.7 & 80.9 \\
\hline Sum of individual beta & 966 & 985 & 970 & 122 \\
\hline Total beta & 91.7 & 954 & 880 & 127 \\
\hline Relative percent difference ${ }^{1}$ & $165 \%$ & $3.2 \%$ & $9.7 \%$ & $3.8 \%$ \\
\hline
\end{tabular}

Note:

${ }^{1}$ Relative percent difference $=$ Absolute value of difference between total activities and gross activities divided by their average.

Table B3-2. Tank 241-S-104 Comparison of Gross Alpha Activities with the Total of the Individual Activities.

\begin{tabular}{|c|c|c|}
\hline 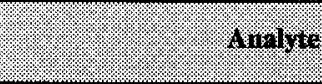 & 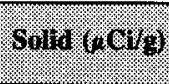 & 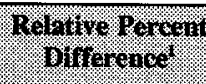 \\
\hline${ }^{239 / 240} \mathrm{Pu}$ & 0.282 & \\
\hline${ }^{241} \mathrm{Am}$ & 0.118 & \\
\hline Sum of individual alpha & 0.400 & \multirow{2}{*}{$42.7 \%$} \\
\hline Total alpha & 0.617 & \\
\hline
\end{tabular}

Note:

'Relative Percent Difference $=$ Absolute value of difference between total activities and gross activities divided by their average.

\section{B3.4.2 Mass and Charge Balance}

The principle objective in performing mass and charge balances is to determine if the measurements are self-consistent. In calculating the balances, only analytes listed in Section B2.0 detected at a concentration of $1,000 \mu \mathrm{g} / \mathrm{g}$ or greater were considered. 
Except sodium, all cations listed in Table B3-3 were assumed to be in their most common hydroxide or oxide form, and the concentrations of the assumed species were calculated stoichiometrically. Because precipitates are neutral species, all positive charge was attributed to the sodium cation. The anions listed in Table B3-4 were assumed to be present as sodium salts and were expected to balance the positive charge exhibited by the cations. The concentrations of cationic species in Table B3-3, the anionic species in Table B3-4, and the percent water were ultimately used to calculate the mass balance.

The following equations demonstrate the derivation of total cations and total anions; the charge balance is the ratio of these two values.

Total cations $(\mu \mathrm{eq} / \mathrm{g})=\left[\mathrm{Na}^{+}\right] / 23.0=5,260 \mu \mathrm{eq} / \mathrm{g}$

Total anions $(\mu \mathrm{eq} / \mathrm{g})=\left[\mathrm{Cl}^{-}\right] / 35.5+\left[\mathrm{NO}_{3}^{-}\right] / 62.0+\left[\mathrm{NO}_{2}^{-}\right] / 46.0+\left[\mathrm{SO}_{4}^{-2}\right] / 48.0+$ $\left[\mathrm{CO}_{3}^{-2}\right] / 30.0+\left[\mathrm{C}_{2} \mathrm{H}_{3} \mathrm{O}^{-}\right] / 59.0=3,830 \mu \mathrm{eq} / \mathrm{g}$

The charge balance obtained by dividing the sum of the positive charge by the sum of the negative charge was 1.37 . The large unbalanced positive charge indicated from the charge balance and the process history of this tank suggests a substantial amount of unquantifiable hydroxide ion is present.

The following equation illustrates that the sum of the total concentration of the assumed species in Table B3-3, the total concentration of anionic analytes in Table B3-4, and the laboratory-derived value for percent water should equal $1,000,000 \mu \mathrm{g} / \mathrm{g}$.

$$
\begin{aligned}
1,000,000 \mu \mathrm{g} / \mathrm{g}= & \mathrm{Al}(\mathrm{OH})_{3}+\mathrm{CaO}+\mathrm{CrO}_{3}+\mathrm{Fe}(\mathrm{O})(\mathrm{OH})+\mathrm{MnO}_{2}+\mathrm{SiO}_{2}+\mathrm{Na}^{+} \\
& +\mathrm{UO}_{2}(\mathrm{OH})_{2}+\mathrm{CO}_{3}{ }^{2-}+\mathrm{C}_{2} \mathrm{H}_{3} \mathrm{O}^{-}+\mathrm{Cl}^{-}+\mathrm{NO}_{3}^{-}+\mathrm{NO}_{2}^{-}+\mathrm{SO}_{4}{ }^{2-}+ \\
& \mathrm{H}_{2} \mathrm{O}
\end{aligned}
$$

Table B3-5 demonstrates that the calculated mass balance differs by 3 percent. The difference in charge balance between cations and anions is probably attribute hydroxide associated with metals. 
Table B3-3. Cation Mass and Charge Data.

\begin{tabular}{|c|c|c|c|c|}
\hline $8: 0$ & Concentration & 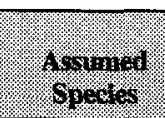 & 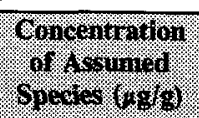 & gravise \\
\hline Aluminum & 117,000 & $\mathrm{Al}(\mathrm{OH})_{3}$ & 338,000 & 0 \\
\hline Calcium & 4,230 & $\mathrm{CaO}$ & 5,920 & $\overline{0}$ \\
\hline Chromium & 2,350 & $\mathrm{CrO}_{3}$ & 4,520 & 0 \\
\hline Iron & 1,720 & $\mathrm{Fe}(\mathrm{O})(\mathrm{OH})$ & 2,740 & 0 \\
\hline Manganese & 1,150 & $\mathrm{MnO}_{2}$ & 1,820 & 0 \\
\hline Silicon & 1,330 & $\mathrm{SiO}_{2}$ & 2,850 & 0 \\
\hline Sodium & 121,000 & $\mathrm{Na}^{+}$ & 121,000 & 5,260 \\
\hline \begin{tabular}{|l|} 
Uranium \\
\end{tabular} & 6,690 & $\mathrm{UO}_{2}(\mathrm{OH})_{2}$ & 8,550 & 0 \\
\hline Totals & & & 485,000 & 5,260 \\
\hline
\end{tabular}

Table B3-4. Anion Mass and Charge Data.

\begin{tabular}{|c|c|c|}
\hline Tा & Consontration $(48)$ & Whing oreqgis \\
\hline Carbonate (TIC) & 4,140 & 138 \\
\hline Acetate (TOC) & 1,520 & 25.7 \\
\hline Chloride & 3,200 & 90.1 \\
\hline Nitrate & 191,000 & 3,080 \\
\hline Nitrite & 20,800 & 452 \\
\hline Sulfate & 2,270 & 47.3 \\
\hline Totals & 223,000 & 3,830 \\
\hline
\end{tabular}

Table B3-5. Mass Balance Totals.

\begin{tabular}{|l|l|}
\hline & \\
\hline Total From Table B3-3 & 485,000 \\
\hline Total From Table B3-4 & 223,000 \\
\hline Water & 316,000 \\
\hline Grand total & $1,030,000$ \\
\hline
\end{tabular}




\section{B3.5 MEAN CONCENTRATIONS AND CONFIDENCE INTERVALS}

The following evaluation was performed on the analytical data from the samples from tank 241-S-104.

Because an inventory estimate is needed without comparing it to a threshold value, two-sided 95 percent confidence intervals on the mean inventory are computed. This was done with composite-level data.

The upper and lower limits (UL and LL) to a two-sided 95 percent confidence interval for the mean are

$$
\hat{\mu} \pm t_{(d f, 0.025)} \times \sqrt{\hat{\sigma}^{2}} .
$$

In these equations, $\hat{\mu}$ is the estimate of the mean concentration, $\hat{\sigma}_{\hat{\mu}}$ is the estimate of the variance of the mean concentration, and $t_{(d f, 0.025)}$ is the quantile from Student's t distribution with df degrees of freedom for a two-sided 95 percent confidence interval.

The mean, $\hat{\mu}$, and the variance, $\hat{\sigma}_{\hat{\mu}}^{2}$, were estimated using restricted maximum likelihood estimation methods. The degrees of freedom ( $\mathrm{df}$ ), for tank $241-\mathrm{S}-104$, is the number of cores sampled minus one.

\section{B3.5.1 Composite Means}

The statistics in this section were based on analytical data from the most recent sampling event of tank 241-S-104. Analysis of variance (ANOVA) techniques were used to estimate the mean, and calculate confidence limits on the mean for all analytes.

The results given below are ANOVA estimates based on the core composite data from core 42 , core 43 , and core 44 for tank S-104. Estimates of the mean concentration and confidence interval on the mean concentration are given in Table B3-6. The lower limit, LL, to a 95 percent confidence interval can be negative. Because an actual concentration of less than zero is not possible, the lower limit is reported as zero, whenever this occurred. 
HNF-SD-WM-ER-370 Rev. 1

Table B3-6. 95 Percent Two-Sided Confidence Interval for the Mean Concentration for Composite Sample Data (Units $\mu \mathrm{g} / \mathrm{g}$ Except Radionuclides $\mu \mathrm{Ci} / \mathrm{g}$ ). (3 sheets)

\begin{tabular}{|c|c|c|c|c|c|}
\hline I nalige & 4. & (3) & ary & $95 \%$ LIV & \%s\% ช \\
\hline ICP.a.Al & $3.89 \mathrm{E}+04$ & $5.05 \mathrm{E}+07$ & 2 & $8.31 E+03$ & $6.94 \mathrm{E}+04$ \\
\hline ICP.a. B $^{2}$ & $1.44 \mathrm{E}+01$ & $1.22 \mathrm{E}+01$ & 2 & $0.00 \mathrm{E}+00$ & $2.94 \mathrm{E}+01$ \\
\hline ICP.a.Ba & $2.16 \mathrm{E}+01$ & $1.01 \mathrm{E}+00$ & 2 & $1.72 \mathrm{E}+01$ & $2.59 \mathrm{E}+01$ \\
\hline ICP.a.Ca ${ }^{2}$ & $2.47 \mathrm{E}+02$ & $6.50 \mathrm{E}+02$ & 2 & $1.37 \mathrm{E}+02$ & $3.56 \mathrm{E}+02$ \\
\hline ICP.a.Ce ${ }^{1}$ & $2.21 \mathrm{E}+01$ & $1.99 \mathrm{E}+00$ & 2 & $1.60 \mathrm{E}+01$ & $2.82 \mathrm{E}+01$ \\
\hline ICP.a.Co ${ }^{1}$ & $2.52 \mathrm{E}+00$ & $2.73 \mathrm{E}-02$ & 2 & $1.81 \mathrm{E}+00$ & $3.23 \mathrm{E}+00$ \\
\hline ICP.a.Cr & $2.35 \mathrm{E}+03$ & $4.01 \mathrm{E}+03$ & 2 & $2.08 \mathrm{E}+03$ & $2.62 \mathrm{E}+03$ \\
\hline ICP.a.Cu & $1.94 \mathrm{E}+01$ & $4.21 \mathrm{E}+01$ & 2 & $0.00 \mathrm{E}+00$ & $4 . \overline{73 E+01}$ \\
\hline ICP.a.Fe & $7.71 \mathrm{E}+02$ & $5.40 \mathrm{E}+03$ & 2 & $4.55 \mathrm{E}+02$ & $1.09 \mathrm{E}+03$ \\
\hline ICP.a.K & $3.00 \mathrm{E}+02$ & $8.07 \mathrm{E}+02$ & 2 & $1.78 \mathrm{E}+02$ & $4.22 \mathrm{E}+02$ \\
\hline ICP.a.Mg & $4.28 \mathrm{E}+01$ & $2.67 \mathrm{E}+01$ & 2 & $2.06 \mathrm{E}+01$ & $6.50 \mathrm{E}+01$ \\
\hline ICP.a.Mn & $9.27 \mathrm{E}+02$ & $1.86 \mathrm{E}+04$ & 2 & $3.40 \mathrm{E}+02$ & $1.51 \mathrm{E}+03$ \\
\hline ICP.a. $\mathrm{Na}$ & $1.21 \mathrm{E}+05$ & $5.22 \mathrm{E}+06$ & 2 & $1.11 \mathrm{E}+05$ & $1.30 \mathrm{E}+05$ \\
\hline ICP.a.Ni & $5.60 \mathrm{E}+01$ & $6.36 \mathrm{E}+00$ & 2 & $4.52 \mathrm{E}+01$ & $6.69 \mathrm{E}+01$ \\
\hline ICP.a.P' & $2.12 \mathrm{E}+01$ & $2.14 \mathrm{E}+00$ & 2 & $1.49 \mathrm{E}+01$ & $2.75 \mathrm{E}+01$ \\
\hline${\mathrm{ICP} \cdot \mathrm{a} \cdot \mathrm{Pb}^{1}}^{1}$ & $2.60 \mathrm{E}+01$ & $5.02 \mathrm{E}+00$ & 2 & $4.40 \mathrm{E}+00$ & $4.76 \mathrm{E}+01$ \\
\hline ICP.a.S & $3.94 \mathrm{E}+02$ & $3.87 \mathrm{E}+02$ & 2 & $3.10 \mathrm{E}+02$ & $4.79 \mathrm{E}+02$ \\
\hline ICP.a.Si & $1.92 \mathrm{E}+02$ & $3.47 \mathrm{E}+02$ & 2 & $1.12 \mathrm{E}+02$ & $2.72 \mathrm{E}+02$ \\
\hline ICP.a.Sr & $3.26 \mathrm{E}+02$ & $1.74 \mathrm{E}+02$ & 2 & $2.69 \mathrm{E}+02$ & $3.82 \mathrm{E}+02$ \\
\hline ICP.a.Ti ${ }^{2}$ & $6.35 \mathrm{E}+00$ & $2.84 \mathrm{E}+00$ & 2 & $0.00 \mathrm{E}+00$ & $1.36 \mathrm{E}+01$ \\
\hline ICP.a. $\mathrm{Zn}^{2}$ & $2.01 \mathrm{E}+01$ & $1.53 \mathrm{E}+01$ & 2 & $3.32 \mathrm{E}+00$ & $3.69 \mathrm{E}+01$ \\
\hline ICP.a.Zr & $3.36 \mathrm{E}+01$ & $7.62 \mathrm{E}-01$ & 2 & $2.99 \mathrm{E}+01$ & $3.74 \mathrm{E}+01$ \\
\hline ICP.f.Al & $1.17 \mathrm{E}+05$ & $1.69 \mathrm{E}+06$ & 2 & $1.11 \mathrm{E}+05$ & $1.23 \mathrm{E}+05$ \\
\hline ICP.f. $B^{1}$ & $2.66 \mathrm{E}+01$ & $1.30 \mathrm{E}+01$ & 2 & $0.00 \mathrm{E}+00$ & $8.25 \mathrm{E}+01$ \\
\hline ICP.f.Ba & $3.31 \mathrm{E}+01$ & $3.32 \mathrm{E}+00$ & 2 & $2.53 \mathrm{E}+01$ & $4.10 \mathrm{E}+01$ \\
\hline ICP.f. $\mathrm{Ca}^{2}$ & $4.23 \mathrm{E}+03$ & $1.14 \mathrm{E}+07$ & 2 & $0.00 \mathrm{E}+00$ & $1.88 \mathrm{E}+04$ \\
\hline ICP.f.Cr & $2.35 \mathrm{E}+03$ & $7.95 \mathrm{E}+03$ & 2 & $1.97 \mathrm{E}+03$ & $2.74 \mathrm{E}+03$ \\
\hline ICP.f. $\mathrm{Cu}^{2}$ & $5.47 \mathrm{E}+01$ & $6.08 \mathrm{E}+01$ & 2 & $2.12 \mathrm{E}+01$ & $8.83 \mathrm{E}+01$ \\
\hline ICP.f.Fe & $1.72 \mathrm{E}+03$ & $1.81 \mathrm{E}+03$ & 2 & $1.53 \mathrm{E}+03$ & $1.90 \mathrm{E}+03$ \\
\hline ICP.f.Mg & $1.57 \mathrm{E}+02$ & $5.04 \mathrm{E}+03$ & 2 & $0.00 \mathrm{E}+00$ & $4.62 \mathrm{E}+02$ \\
\hline
\end{tabular}


Table B3-6. 95 Percent Two-Sided Confidence Interval for the Mean Concentration for Composite Sample Data (Units $\mu \mathrm{g} / \mathrm{g}$ Except Radionuclides $\mu \mathrm{Ci} / \mathrm{g}$ ). (3 sheets)

\begin{tabular}{|c|c|c|c|c|c|}
\hline Twarto & 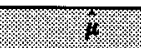 & (1) & of & 9586. IU & 158\% 6 \\
\hline ICP.f.Mn & $1.15 \mathrm{E}+03$ & $4.73 \mathrm{E}+04$ & 2 & $2.15 \mathrm{E}+02$ & $2.09 \mathrm{E}+03$ \\
\hline ICP.f.Na & $1.18 \mathrm{E}+05$ & $2.77 \mathrm{E}+06$ & 2 & $1.11 \mathrm{E}+05$ & $1.25 \mathrm{E}+05$ \\
\hline ICP.f.Ni & $5.01 \mathrm{E}+03$ & $1.84 \mathrm{E}+05$ & 2 & $3.16 \mathrm{E}+03$ & $6.85 \mathrm{E}+03$ \\
\hline ICP.f.P ${ }^{1}$ & $9.31 \mathrm{E}+01$ & $5.97 \mathrm{E}+01$ & 2 & $5.98 \mathrm{E}+01$ & $1.26 \mathrm{E}+02$ \\
\hline ICP.f.S & $4.72 \mathrm{E}+02$ & $2.00 \mathrm{E}+02$ & 2 & $4.11 \mathrm{E}+02$ & $5.33 \mathrm{E}+02$ \\
\hline ICP.f.Si & $1.33 \mathrm{E}+03$ & $1.52 \mathrm{E}+04$ & 2 & $7.97 \mathrm{E}+02$ & $1.86 \mathrm{E}+03$ \\
\hline ICP.f.Sr & $4.24 \mathrm{E}+02$ & $3.03 E+02$ & 2 & $3.49 \mathrm{E}+02$ & $1.86 \mathrm{E}+03$ \\
\hline ICP.f.Ti $^{1}$ & $7.50 \mathrm{E}+00$ & $1.09 \mathrm{E}+00$ & 2 & $2.83 \mathrm{E}+00$ & $1.22 \mathrm{E}+01$ \\
\hline ICP.f. $\mathrm{Zn}^{2}$ & $2.24 \mathrm{E}+02$ & $2.16 \mathrm{E}+04$ & 2 & $0.00 \mathrm{E}+00$ & $8.56 \mathrm{E}+02$ \\
\hline ICP.f. $\mathrm{Zr}^{1}$ & $2.12 \mathrm{E}+01$ & $3.69 \mathrm{E}+01$ & 2 & $0.00 \mathrm{E}+00$ & $4.73 \mathrm{E}+01$ \\
\hline ICP.w.Al & $4.68 \mathrm{E}+03$ & $2.43 \mathrm{E}+06$ & 2 & $0.00 \mathrm{E}+00$ & $1.14 \mathrm{E}+04$ \\
\hline$\overline{\text { ICP.w. } \text { B }^{1}}$ & $9.08 \mathrm{E}+00$ & $1.65 \mathrm{E}+00$ & 2 & $3.57 \mathrm{E}+00$ & $1.46 \mathrm{E}+01$ \\
\hline ICP.w.Ca ${ }^{1}$ & $1.56 \mathrm{E}+02$ & $3.35 \mathrm{E}+03$ & 2 & $0.00 \mathrm{E}+00$ & $4.04 \mathrm{E}+02$ \\
\hline ICP.w.Cr & $1.90 \mathrm{E}+03$ & $4.39 \mathrm{E}+05$ & 2 & $0.00 \mathrm{E}+00$ & $4.75 \mathrm{E}+03$ \\
\hline ICP.w.Cu ${ }^{1}$ & $1.47 \mathrm{E}+00$ & $6.78 \mathrm{E}-01$ & 2 & $0.00 \mathrm{E}+00$ & $4.39 \mathrm{E}+00$ \\
\hline ICP.w.Fe & $1.24 \mathrm{E}+01$ & $8.56 \mathrm{E}+00$ & 2 & $0.00 \mathrm{E}+00$ & $4.92 \mathrm{E}+01$ \\
\hline ICP.w.K & $2.53 \mathrm{E}+02$ & $4.62 \mathrm{E}+03$ & 2 & $0.00 \mathrm{E}+00$ & $5.45 \mathrm{E}+02$ \\
\hline ICP.w.Mg ${ }^{1}$ & $8.34 \mathrm{E}+00$ & $1.10 \mathrm{E}+01$ & 2 & $0.00 \mathrm{E}+00$ & $2.26 \mathrm{E}+01$ \\
\hline ICP.w.Na & $9.21 \mathrm{E}+04$ & $7.38 \mathrm{E}+08$ & 2 & $0.00 \mathrm{E}+00$ & $2.09 \mathrm{E}+05$ \\
\hline ICP.w.S & $3.40 \mathrm{E}+02$ & $1.45 \mathrm{E}+04$ & 2 & $0.00 \mathrm{E}+00$ & $8.58 \mathrm{E}+02$ \\
\hline ICP.w.Si ${ }^{2}$ & $3.98 \mathrm{E}+01$ & $2.87 \mathrm{E}+02$ & 2 & $0.00 \mathrm{E}+00$ & $1.13 \mathrm{E}+02$ \\
\hline ICP.w.Sr ${ }^{1}$ & $6.89 \mathrm{E}-01$ & $6.20 \mathrm{E}-02$ & 2 & $4.22 \mathrm{E}-01$ & $9.56 \overline{\mathrm{E}}-01$ \\
\hline ICP.w. $\mathrm{Zn}^{1}$ & $1.40 \mathrm{E}+01$ & $3.33 \mathrm{E}+00$ & 2 & $0.00 \mathrm{E}+00$ & $2.83 \mathrm{E}+01$ \\
\hline IC.w.Cl & $3.20 \mathrm{E}+03$ & $8.96 \mathrm{E}+03$ & 2 & $2.79 \mathrm{E}+03$ & $3.61 \mathrm{E}+03$ \\
\hline IC.w.NO2 & $2.08 \mathrm{E}+04$ & $2.46 \mathrm{E}+06$ & 2 & $1.41 \mathrm{E}+04$ & $2.76 \mathrm{E}+04$ \\
\hline IC.w.NO3 & $1.91 \mathrm{E}+05$ & $3.64 \mathrm{E}+07$ & 2 & $1.65 \mathrm{E}+05$ & $2.17 \mathrm{E}+05$ \\
\hline IC.w.SO4 & $2.27 \mathrm{E}+03$ & $3.92 \mathrm{E}+03$ & 2 & $2.00 \mathrm{E}+03$ & $2.54 \mathrm{E}+03$ \\
\hline $\mathrm{CN}$ & $3.70 \mathrm{E}+00$ & $4.34 \mathrm{E}-02$ & 2 & $2.81 \mathrm{E}+00$ & $4.60 \mathrm{E}+00$ \\
\hline Percent.H2O & $5.16 \mathrm{E}+01$ & $4.64 \mathrm{E}+02$ & 2 & $0.00 \mathrm{E}+00$ & $1.44 \mathrm{E}+02$ \\
\hline $\mathrm{TOC}^{1}$ & $1.52 \mathrm{E}+03$ & $3.42 \mathrm{E}+02$ & 2 & $5.15 \mathrm{E}+01$ & $2.99 \mathrm{E}+03$ \\
\hline
\end{tabular}


Table B3-6. 95 Percent Two-Sided Confidence Interval for the Mean Concentration for Composite Sample Data (Units $\mu \mathrm{g} / \mathrm{g}$ Except Radionuclides $\mu \mathrm{Ci} / \mathrm{g}$ ). (3 sheets)

\begin{tabular}{|c|c|c|c|c|c|}
\hline Pnolyte & 4 & 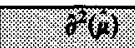 & dI & $95 \%$ U1 & 95\% 61 \\
\hline Spec.w.NO2 & $2.59 \mathrm{E}+04$ & $1.16 \mathrm{E}+06$ & 2 & $2.12 \mathrm{E}+04$ & $3.05 \mathrm{E}+04$ \\
\hline TIC.w.CO3 & $4.14 \mathrm{E}+03$ & $4.86 \mathrm{E}+05$ & 2 & $1.15 \mathrm{E}+03$ & $7.14 \mathrm{E}+03$ \\
\hline$\overline{\mathrm{pH}}$ & $1.29 \mathrm{E}+01$ & $6.30 \mathrm{E}-02$ & 2 & $1.18 \mathrm{E}+01$ & $1.39 \mathrm{E}+01$ \\
\hline $\mathrm{C}-14^{1}$ & $9.01 \mathrm{E}-04$ & $1.42 \mathrm{E}-08$ & 2 & $3.88 \mathrm{E}-04$ & $1.41 \mathrm{E}-03$ \\
\hline GEA.Cs-137 & $6.23 \mathrm{E}+01$ & $3.45 \mathrm{E}+00$ & 2 & $5.43 \mathrm{E}+01$ & $7.03 \mathrm{E}+01$ \\
\hline Gross.alpha ${ }^{1}$ & $6.17 \mathrm{E}-01$ & $6.92 \mathrm{E}-02$ & 2 & $3.19 \mathrm{E}-01$ & $9.14 \mathrm{E}-01$ \\
\hline Gross.beta & $6.41 \mathrm{E}+02$ & $7.60 \mathrm{E}+04$ & 2 & $0.00 \mathrm{E}+00$ & $1.83 \mathrm{E}+03$ \\
\hline $\mathrm{H}-3^{2}$ & $3.38 \mathrm{E}-03$ & $1.59 \mathrm{E}-07$ & 2 & $1.66 \mathrm{E}-03$ & $5.09 \mathrm{E}-03$ \\
\hline $\mathrm{Pu}-239 / 40$ & $2.82 \mathrm{E}-01$ & $4.67 \mathrm{E}-03$ & 2 & $0.00 \mathrm{E}+00$ & $5.76 \mathrm{E}-01$ \\
\hline $\mathrm{Sr}-90$ & $3.10 \mathrm{E}+02$ & $6.23 \mathrm{E}+01$ & 2 & $2.76 \mathrm{E}+02$ & $3.44 \mathrm{E}+02$ \\
\hline Tc-99 & $2.42 \mathrm{E}-02$ & $1.70 \mathrm{E}-06$ & 2 & $1.86 \mathrm{E}-02$ & $2.98 \mathrm{E}-02$ \\
\hline $\mathrm{U}^{2}$ & $6.69 \mathrm{E}+03$ & $1.37 \mathrm{E}+05$ & 2 & $5.09 \mathrm{E}+03$ & $8.28 \mathrm{E}+03$ \\
\hline
\end{tabular}

\section{B3.5.2 Analysis of Variance Models}

A statistical model is needed to account for the spatial and measurement variability in $\hat{\sigma}_{\hat{\hat{\omega}}}^{2}$. This cannot be done using an ordinary variance of the data (Snedecor and Cochran 1980).

The statistical model fit to the composite sample data is

$$
\begin{gathered}
Y_{i j k}=\mu+S_{i}+C_{i j}+A_{i j k}, \\
i=1, \ldots, a, j=1, \ldots, b_{i}, k=1, \ldots, c_{i j}
\end{gathered}
$$


where
$\mathrm{Y}_{\mathrm{ijk}} \quad=\quad$ laboratory results from the $\mathrm{k}^{\text {th }}$ duplicate from the $\mathrm{j}^{\text {th }}$ composite in the $i^{\text {th }}$ core in the tank
$\mu \quad=\quad$ the grand mean
$S_{i}=$ the effect of the $i^{\text {th }}$ core
$\mathrm{C}_{\mathrm{ij}}=$ the effect of the $\mathrm{j}^{\text {th }}$ composite in the $\mathrm{i}^{\text {th }}$ core
$\mathrm{A}_{\mathrm{ijk}} \quad=\quad$ the effect of the $\mathrm{k}^{\text {th }}$ analytical result from the $\mathrm{j}^{\mathrm{th}}$ composite in the $i^{\text {th }}$ core
a $\quad=\quad$ the number of cores
$b_{i}=$ the number of composites in the $i^{\text {th }}$ core
$\mathrm{c}_{\mathrm{ij}} \quad=\quad$ the number of analytical results from the $j^{\text {th }}$ composite in the $\mathrm{i}^{\text {th }}$ core.

The variables $S_{i}$ and $C_{i j}$ are assumed to be random effects. These variables and $A_{i j}$ are assumed to be uncorrelated and normally distributed with means zero and variances $\sigma^{2}(S)$, $\sigma^{2}(\mathrm{C})$, and $\sigma^{2}(\mathrm{~A})$, respectively. Estimates of $\sigma^{2}(\mathrm{~S}), \sigma^{2}(\mathrm{C})$, and $\sigma^{2}(\mathrm{~A})$ were obtained using restricted maximum likelihood estimation techniques. This method, applied to variance component estimation, is described in Harville (1997). The statistical results were obtained using the statistical analysis package S-PLUS ${ }^{1}$ (Statistical Sciences, Inc. 1993).

\section{B3.5.3 Inventory}

After the sample means are calculated for the tank for each analyte, the sampling-based inventory may be calculated. Because the analyte concentrations above are presented in terms of a mass basis concentration, the total mass of waste in the tank is needed to estimate inventories. The total mass of waste is derived from the tank volume (from surveillance) and the estimated tank solids density. The tank volume for solids is $1,113 \mathrm{~kL}$ (Hanlon 1996). The density used for this estimate is $1.64 \mathrm{~g} / \mathrm{mL}$ for composite sample data. The inventory of each of the analytes is presented in Table B3-7 for composite sample data.

\footnotetext{
${ }^{1}$ Trademark of Statistical Sciences, Inc., Seattle, Washington.
} 
HNF-SD-WM-ER-370 Rev. 1

Table B3-7. Analytical-Based Inventory for Composite Sample Data for Tank 241-S-104. (3 sheets)

\begin{tabular}{|c|c|c|c|}
\hline 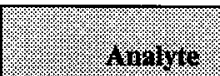 & 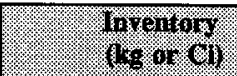 & tys. & UI. \\
\hline ICP.a.Al & $7.08 \mathrm{E}+04$ & $1.51 \mathrm{E}+04$ & $1.26 \mathrm{E}+05$ \\
\hline ICP.a.B & $2.62 \mathrm{E}+01$ & $0.00 \mathrm{E}+00$ & $5 . \overline{36 \mathrm{E}+01}$ \\
\hline ICP.a.Ba & $3.93 \mathrm{E}+01$ & $3.14 \mathrm{E}+01$ & $4.72 \mathrm{E}+01$ \\
\hline ICP.a.Ca & $4.50 \mathrm{E}+02$ & $2.50 \mathrm{E}+02$ & $6.49 \mathrm{E}+02$ \\
\hline ICP.a.Ce & $4.02 \mathrm{E}+01$ & $2.92 \mathrm{E}+01$ & $5.13 \mathrm{E}+01$ \\
\hline ICP.a.Co & $4.59 \mathrm{E}+00$ & $3.29 \mathrm{E}+00$ & $5.88 \mathrm{E}+00$ \\
\hline ICP.a.Cr & $4.28 \mathrm{E}+03$ & $3.78 \mathrm{E}+03$ & $4.77 \mathrm{E}+03$ \\
\hline ICP.a.Cu & $3.53 \mathrm{E}+01$ & $0.00 \mathrm{E}+00$ & $8.61 \mathrm{E}+01$ \\
\hline ICP.a.Fe & $1.40 \mathrm{E}+03$ & $8.28 \mathrm{E}+02$ & $1.98 \mathrm{E}+03$ \\
\hline ICP.a.K & $5.46 \mathrm{E}+02$ & $3.24 \mathrm{E}+02$ & $7.69 \mathrm{E}+02$ \\
\hline ICP.a.Mg & $7.79 \mathrm{E}+01$ & $3.74 \mathrm{E}+01$ & $1.18 \mathrm{E}+02$ \\
\hline ICP.a.Mn & $1.69 \mathrm{E}+03$ & $6.19 \mathrm{E}+02$ & $2.76 \mathrm{E}+03$ \\
\hline ICP.a.Na & $2.20 \mathrm{E}+05$ & $2.02 \mathrm{E}+05$ & $2.38 \mathrm{E}+05$ \\
\hline ICP.a.Ni & $1.02 \mathrm{E}+02$ & $8.22 \mathrm{E}+01$ & $1.22 \mathrm{E}+02$ \\
\hline \begin{tabular}{|l|} 
ICP.a.P \\
\end{tabular} & \begin{tabular}{|l|}
$3.86 \mathrm{E}+01$ \\
\end{tabular} & $2.71 \mathrm{E}+01$ & $5.01 \mathrm{E}+01$ \\
\hline ICP.a.Pb & $4.73 \mathrm{E}+01$ & $8.01 \mathrm{E}+01$ & $8.67 \mathrm{E}+01$ \\
\hline ICP.a.S & $7.17 \mathrm{E}+02$ & $5.63 \mathrm{E}+02$ & $8.71 E+02$ \\
\hline ICP.a.Si & $3.50 \mathrm{E}+02$ & $2.04 \mathrm{E}+02$ & $4.95 \mathrm{E}+02$ \\
\hline ICP.a.Sr & $5.93 \mathrm{E}+02$ & $4.90 \mathrm{E}+02$ & $6.97 \mathrm{E}+02$ \\
\hline ICP.a.Ti & $1.16 \mathrm{E}+01$ & $0.00 \mathrm{E}+00$ & $2.48 \mathrm{E}+01$ \\
\hline ICP.a.Zn & $3.66 \mathrm{E}+01$ & $5.95 \mathrm{E}+00$ & $6.72 \mathrm{E}+01$ \\
\hline ICP.a.Zr & $6.12 \mathrm{E}+01$ & $5.43 \mathrm{E}+01$ & $6.80 \mathrm{E}+01$ \\
\hline ICP.f.Al & $2.13 \mathrm{E}+05$ & $2.03 \mathrm{E}+05$ & $2.23 \mathrm{E}+05$ \\
\hline ICP.f.B & $4.85 \mathrm{E}+01$ & $0.00 \mathrm{E}+00$ & $1.50 \mathrm{E}+02$ \\
\hline ICP.f.Ba & $6.03 \mathrm{E}+01$ & $4.60 \mathrm{E}+01$ & $7.45 \mathrm{E}+01$ \\
\hline ICP.f.Ca & $7.70 \mathrm{E}+03$ & $0.00 \mathrm{E}+00$ & $3.41 \mathrm{E}+04$ \\
\hline ICP.f.Cr & $4.28 \mathrm{E}+03$ & $3.58 \mathrm{E}+03$ & $4.98 \mathrm{E}+03$ \\
\hline ICP.f.Cu & $9.96 \mathrm{E}+01$ & $3.85 \mathrm{E}+01$ & $1.61 \mathrm{E}+02$ \\
\hline ICP.f.Fe & $3.13 \mathrm{E}+03$ & $2.80 \mathrm{E}+03$ & $3.46 \mathrm{E}+03$ \\
\hline ICP.f.Mg & $2.86 \mathrm{E}+02$ & $0.00 \mathrm{E}+00$ & $8.42 \mathrm{E}+02$ \\
\hline
\end{tabular}


HNF-SD-WM-ER-370 Rev. 1

Table B3-7. Analytical-Based Inventory for Composite Sample Data for Tank 241-S-104. (3 sheets)

\begin{tabular}{|c|c|c|c|}
\hline Alnatite: & 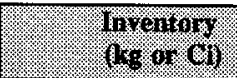 & 14 & (4) \\
\hline ICP.f.Mn & $2.09 \mathrm{E}+03$ & $3.90 \mathrm{E}+02$ & $3.80 \mathrm{E}+03$ \\
\hline ICP.f.Na & $2.15 \mathrm{E}+05$ & $2.02 \mathrm{E}+05$ & $2.28 \mathrm{E}+05$ \\
\hline ICP.f.Ni & $9.12 \mathrm{E}+03$ & $5.76 \mathrm{E}+03$ & $1.25 \mathrm{E}+04$ \\
\hline ICP.f.P & $1.69 \mathrm{E}+02$ & $1.09 \mathrm{E}+02$ & $2.30 \mathrm{E}+02$ \\
\hline ICP.f.S & $8.59 \mathrm{E}+02$ & $7.48 \mathrm{E}+02$ & $9.70 \mathrm{E}+02$ \\
\hline ICP.f.Si & $2.42 \mathrm{E}+03$ & $1.46 \mathrm{E}+03$ & $3.39 \mathrm{E}+03$ \\
\hline \begin{tabular}{|l|} 
ICP.f.Sr \\
\end{tabular} & $7.72 \mathrm{E}+02$ & $6.35 \mathrm{E}+02$ & $9.08 \mathrm{E}+02$ \\
\hline \begin{tabular}{|l} 
ICP.f.Ti \\
\end{tabular} & $1.37 \mathrm{E}+01$ & $5.15 \mathrm{E}+00$ & $2.22 \mathrm{E}+01$ \\
\hline ICP.f.Zn & $4.08 \mathrm{E}+02$ & $0.00 \mathrm{E}+00$ & $1.56 \mathrm{E}+03$ \\
\hline ICP.f.Zr & $3.86 \mathrm{E}+01$ & $0.00 \mathrm{E}+00$ & $8.62 \mathrm{E}+01$ \\
\hline ICP.w.Al & $8.52 \mathrm{E}+03$ & $0.00 \mathrm{E}+00$ & $2.07 \mathrm{E}+04$ \\
\hline ICP.w.B & $1.65 \mathrm{E}+01$ & $6.47 \mathrm{E}+00$ & $2.66 \mathrm{E}+01$ \\
\hline ICP.w.Ca & $2.84 \mathrm{E}+02$ & $0.00 \mathrm{E}+00$ & $7.37 \mathrm{E}+02$ \\
\hline ICP.w.Cr & $3.46 \mathrm{E}+03$ & $0.00 \mathrm{E}+00$ & $8.65 \mathrm{E}+03$ \\
\hline ICP.w.Cu & $2.68 \mathrm{E}+00$ & $0.00 \mathrm{E}+00$ & $7.99 \mathrm{E}+00$ \\
\hline ICP.w.Fe & $2.26 \mathrm{E}+01$ & $0.00 \mathrm{E}+00$ & $8.96 \mathrm{E}+01$ \\
\hline ICP.w.K & $4.61 \mathrm{E}+02$ & $0.00 \mathrm{E}+00$ & $9.93 \mathrm{E}+02$ \\
\hline ICP.w.Mg & $1.52 \mathrm{E}+01$ & $0.00 \mathrm{E}+00$ & $4.12 \mathrm{E}+01$ \\
\hline ICP.w.Na & $1.68 \mathrm{E}+05$ & $0.00 \mathrm{E}+00$ & $3.80 \mathrm{E}+05$ \\
\hline ICP.w.S & $6.19 \mathrm{E}+02$ & $0.00 \mathrm{E}+00$ & $1.56 \mathrm{E}+03$ \\
\hline ICP.w.Si & $7.25 \mathrm{E}+01$ & $0.00 \mathrm{E}+00$ & $2.05 \mathrm{E}+02$ \\
\hline ICP.w.Sr & $1.25 \mathrm{E}+00$ & $7.68 \mathrm{E}-01$ & $1.74 \mathrm{E}+00$ \\
\hline ICP.w.Zn & $2.55 \mathrm{E}+01$ & $0.00 \mathrm{E}+00$ & $5.16 \mathrm{E}+01$ \\
\hline IC.w.Cl & $5.83 \mathrm{E}+03$ & $5.08 \mathrm{E}+03$ & $6.57 \mathrm{E}+03$ \\
\hline IC.w.NO2 & $3.79 \mathrm{E}+04$ & $2.56 \mathrm{E}+04$ & $5.02 \mathrm{E}+04$ \\
\hline IC.w.NO3 & $3.48 \mathrm{E}+05$ & $3.00 \mathrm{E}+05$ & $3.95 \mathrm{E}+05$ \\
\hline IC.w.SO4 & $4.13 \mathrm{E}+03$ & $3.64 \mathrm{E}+03$ & $4.62 \mathrm{E}+03$ \\
\hline$\overline{\mathrm{CN}}$ & $6.74 \mathrm{E}+00$ & $5.10 \mathrm{E}+00$ & $8.37 \mathrm{E}+00$ \\
\hline Spec.w.NO2 & $4.71 \mathrm{E}+04$ & $3.87 \mathrm{E}+04$ & $5.56 \mathrm{E}+04$ \\
\hline TOC & $2.77 \mathrm{E}+03$ & $9.37 \mathrm{E}+01$ & $5.45 \mathrm{E}+03$ \\
\hline
\end{tabular}


Table B3-7. Analytical-Based Inventory for Composite Sample Data for Tank 241-S-104. (3 sheets)

\begin{tabular}{|c|c|c|c|}
\hline Aringte & $\begin{array}{l}\text { Irverions } \\
\text { us or Cit }\end{array}$ & U1. & (10) \\
\hline TOC.W.CO3 & $7.54 \mathrm{E}+03$ & $2.08 \mathrm{E}+03$ & $1.30 \mathrm{E}+04$ \\
\hline$\vec{U}$ & $1.22 \mathrm{E}+04$ & $9.28 \mathrm{E}+03$ & $1.51 \mathrm{E}+04$ \\
\hline Percent water & $9.39 \mathrm{E}+05$ & $0.00 \mathrm{E}+00$ & $1.82 \mathrm{E}+06$ \\
\hline C-14 & $1.64 \mathrm{E}+00$ & $7.07 \mathrm{E}-01$ & $2.57 \mathrm{E}+00$ \\
\hline GEA.Cs-137 & $1.13 \mathrm{E}+05$ & $9.89 \mathrm{E}+04$ & $1.28 \mathrm{E}+05$ \\
\hline Gross.alpha & $1.12 \mathrm{E}+03$ & $5.81 \mathrm{E}+02$ & $1.66 \mathrm{E}+03$ \\
\hline Gross.beta & $1.17 \mathrm{E}+06$ & $0.00 \mathrm{E}+00$ & $3.33 E+06$ \\
\hline $\mathrm{H}-3$ & $6.15 \mathrm{E}+00$ & $3.03 E+00$ & $9.28 \mathrm{E}+00$ \\
\hline $\mathrm{Pu}-239 / 40$ & $5.13 \mathrm{E}+02$ & $0.00 \mathrm{E}+00$ & $1.05 \mathrm{E}+03$ \\
\hline Sr-90 & $5.64 \mathrm{E}+05$ & $5.02 \mathrm{E}+05$ & $6.26 \mathrm{E}+05$ \\
\hline Tc-99 & $4.41 \mathrm{E}+01$ & $3.38 \mathrm{E}+01$ & $5.43 \mathrm{E}+01$ \\
\hline
\end{tabular}

\section{B4.0 APPENDIX B REFERENCES}

Bell, K. E., 1994, Tank Waste Remediation System Tank Waste Analysis Plan, WHC-SD-WM-PLN-077, Rev. 0, Westinghouse Hanford Company, Richland, Washington.

De Lorenzo, D. S., J. H. Rutherford, D. J. Smith, D. B. Hiller, K. W. Johnson, 1994, Tank Characterization Reference Guide, LATA-TCR-9491, Los Alamos Technical Associates, Kennewick, Washington.

Dukelow, G. T., J. W. Hunt, H. Babad, and J. E Meacham, 1995, Tank Safety Screening Data Quality Objective, WHC-SD-WM-SP-004, Rev. 2, Westinghouse Hanford Company, Richland, Washington.

Hanlon, B. L., 1996, Tank Farm Surveillance and Waste Status Summary Report for Month Ending September 30, 1996, WHC-EP-0182-102, Westinghouse Hanford Company, Richland, Washington.

Harville, D. A., 1977, "Maximum Likelihood Approaches to Variance Component Estimation and to Related Problems," Joumal of the American Statistical Association, vol. 72 , pp. $320-340$. 
Hill, J. G., W. I. Winters, and B. C. Simpson, 1991, Waste Characterization Plan for the Hanford Site Single-Shell Tanks, WHC-EP-0210, Rev. 3, Westinghouse Hanford Company, Richland, Washington.

Horton, J. E., 1976, Characterization and Analysis of Tank 104-S Sludge, (letter [number unknown] to W. R. Christensen, February 24), Atlantic Richfield Hanford Company, Richland, Washington.

Kocher, K. L., 1993, Single-Shell Waste Characterization Tank 241-S-104, Data Package, WHC-SD-WM-DP-031, Rev. 0, Westinghouse Hanford Company, Richland, Washington.

Snedecor, G. W., and W. G. Cochran, 1980, Statistical Methods, 7th Edition, Iowa State University Press, Ames, Iowa.

Statistical Sciences, Inc., 1993, S-PLUS Reference Manual, Version 3.2, Seattle: StatSci, a division of MathSoft, Inc.

WHC, 1993, Data Package S-104 Validation Summary, WHC-SD-WM-DP-031, Rev. 0, Addendum 2, Westinghouse Hanford Company, Richland, Washington.

Wheeler, R. E., 1974, Analysis of Tank Farm Samples, Sample T-4184 104-S, (internal letter to R. L. Walser, August 12), Atlantic Richfield Company, Richland, Washington.

Winters, W. I., L. Jensen, L. M. Sasaki, R. C. Weiss, J. F. Keller, A. J. Schmidt, and M. G. Woodruff, 1990, Waste Characterization Plan for the Hanford Site Single-Shell Tanks, WHC-EP-0210, Rev. 2, Westinghouse Hanford Company, Richland, Washington. 
HNF-SD-WM-ER-370 Rev. 1

This page left blank intentionally. 
HNF-SD-WM-ER-370 Rev. 1

APPENDIX C

STATISTICAL ANALYSIS FOR ISSUE RESOLUTION

C-1 
HNF-SD-WM-ER-370 Rev. 1

This page intentionally left blank. 


\section{APPENDIX C}

\section{STATISTICAL ANALYSIS FOR ISSUE RESOLUTION}

In Appendix C, the results of the analyses required for the applicable data quality objective (DQO) reports for tank 241-S-104 are reported. Specifically, the results of statistical and other numerical manipulations required in the DQO reports are performed and documented in this appendix. The analyses required for tank 241-S-104 are documented in the following sections:

- Section C1: Statistical analysis supporting the safety screening DQO (Dukelow et al. 1995). Specifically, confidence intervals were needed to support the plutonium (criticality) threshold limit.

- Section C2: Reference for Appendix C.

\section{C1.0 STATISTICS FOR SAFETY SCREENING DQO}

The safety screening DQO (Dukelow et al. 1995) defines acceptable decision confidence limits in terms of one-sided 95 percent confidence intervals on the mean for each subsample. In this appendix, one sided confidence limits supporting the safety screening DQO are calculated for tank 241-S-104. All data considered in this section are taken from the 1992 sampling event.

Confidence intervals were computed for core composites from tank 241-S-104 analytical data. The core composite numbers and confidence intervals are provided in Table C1-1.

The upper limit (UL) of a one-sided 95 percent confidence interval for the mean is

$$
\hat{\mu}+t_{(\mathbf{n}-1,0.95)} * \sqrt{\frac{\hat{\sigma}^{2}}{\mathrm{n}}}
$$

where $\hat{\mu}$ is the arithmetic mean of the data, $n$ is the number of observations, $\hat{\sigma}^{2}$ is the estimate of the variance of the data, and $t_{(n-1,0.95)}$ is a quantile from Student's $t$ distribution with $n-1$ degrees of freedom and 0.95 confidence. 
Table C1-1. 95 Percent Confidence Interval Upper Limits for Total Alpha for Tank 241-S-104.

\begin{tabular}{|c|c|c|c|c|c|}
\hline winger & 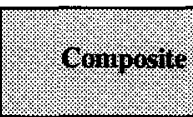 & Iesul: & istan & 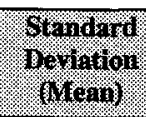 & 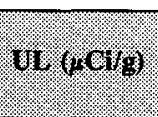 \\
\hline 42 & 1 & 0.701 & & & \\
\hline 42 & 1 & 0.352 & 0.5265 & 0.1745 & 1.628293 \\
\hline 42 & 2 & 0.578 & & & \\
\hline 42 & 2 & 0.72 & 0.649 & 0.071 & 1.097294 \\
\hline 43 & 1 & 0.807 & & & \\
\hline 43 & 1 & 0.779 & 0.793 & 0.014 & 0.881396 \\
\hline 43 & 2 & 0.998 & & & \\
\hline 43 & 2 & 0.916 & 0.957 & 0.041 & 1.215874 \\
\hline 44 & 1 & 0.432 & & & \\
\hline 44 & 1 & 0.489 & 0.4605 & 0.0285 & 0.640449 \\
\hline 44 & 2 & 0.39 & & & \\
\hline 44 & 2 & 0.239 & 0.3145 & 0.0755 & 0.791207 \\
\hline
\end{tabular}

The upper limit of the 95 percent confidence interval for each sample number based on the total alpha data is listed in Table C1-1. Each confidence interval can be used to make the following statement. If the upper limit is less than $40 \mu \mathrm{Ci} / \mathrm{g}$, then one would reject the null hypothesis that the total alpha is greater than or equal to $40 \mu \mathrm{Ci} / \mathrm{g}$ at the 0.05 level of significance.

Confidence intervals were not performed on the DSC data, because all the segment samples had no exotherms.

\section{C2.0 APPENDIX C REFERENCE}

Dukelow, G. T., J. W. Hunt, H. Babad, and J. E. Meacham, 1995, Tank Safety Screening Data Quality Objective, WHC-SD-WM-SP-004, Rev. 2, Westinghouse Hanford Company, Richland, Washington. 
HNF-SD-WM-ER-370 Rev. 1

APPENDIX D

RESULTS OF THE EVALUATION TO ESTABLISH BEST-BASIS

STANDARD INVENTORY FOR TANK 241-S-104

D-1 
HNF-SD-WM-ER-370 Rev. 1

This page intentionally left blank. 


\section{APPENDIX D}

\section{RESULTS OF THE EVALUATION TO ESTABLISH BEST-BASIS STANDARD INVENTORY FOR TANK 241-S-104}

An effort is underway to provide waste inventory estimates that will serve as standard characterization source terms for the various waste management activities (Hodgson and LeClair 1996). As part of this effort, an evaluation of available waste-related information for single-shell tank 241-S-104 was performed, and a best-basis inventory was established. This work, detailed in the following sections, follows the methodology that was established by the standard inventory task.

\section{D1.0 CHEMICAL INFORMATION SOURCES}

Available waste (chemical) information for tank 241-S-104 included:

- Data from three push-mode cores samples that were collected in 1992. See Appendix B, Section B2.0 for data.

- Data from pre-1989 analyses, which were used for informational purposes only.

- The inventory estimate for this tank (Agnew et al. 1996) generated from the HDW model. See Section A3.2 for the model estimate.

- Analytical data from TCRs from tanks with the same R sludge waste types (241-S-104 [this TCR], Appendix B), 241-S-107 (Simpson et al. 1996) and 241-S-101 (Kruger et al. 1996). A list of references used in this evaluation is provided in Section D5.0.

\section{D2.0 COMPARISON OF COMPONENT INVENTORY VALUES}

In Tables D2-1 and D2-2, sampling-based inventories (see Appendix B, Section B3.2) derived from the analytical concentration data from the core samples are compared with the HDW model inventories. Table D2-1 compares nonradioactive components on a kilogram $(\mathrm{kg})$ basis, and Table D2-2 compares the radioactive components on a curie basis. See Section D3-1 for details on sample types, volumes and densities. 
By comparing Tables D2-1 and D2-2, note the differences between the sample-based values for tank 241-S-104 and the HDW model inventories of this tank, for several of the bulk components.

The ICP metals data for the sampling-based inventory are from fusion with the exception of $\mathrm{Ni}, \mathrm{K}, \mathrm{Na}$ and $\mathrm{Zr}$, for which the acid preparation method was used.

Table D2-1. Sampling-Based and Hanford Defined Waste-Based Inventory Estimates for Nonradioactive Components in Tank 241-S-104. (2 sheets)

\begin{tabular}{|c|c|c|c|c|c|}
\hline 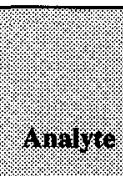 & 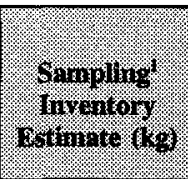 & 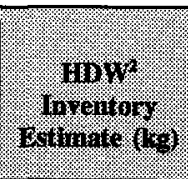 & 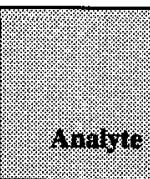 & 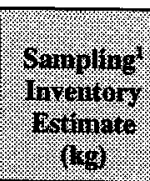 & 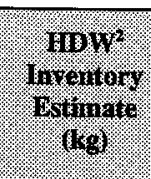 \\
\hline $\mathrm{Al}$ & 214,000 & 95,700 & $\mathrm{Ni}$ & 102 & 1,760 \\
\hline $\mathrm{Ba}$ & 60.4 & $n / r$ & $\mathrm{NO}_{2}$ & 38,000 & 92,900 \\
\hline$\overline{\mathrm{Bi}}$ & $n / r$ & 0.966 & $\mathrm{NO}_{3}$ & 349,000 & 204,000 \\
\hline $\mathrm{Ca}$ & 7,700 & 5,830 & $\mathrm{OH}$ & $n / r$ & 260,000 \\
\hline $\mathrm{Ce}$ & 40.3 & $n / r$ & oxalate & $n / r$ & $1 \mathrm{E}-06$ \\
\hline $\mathrm{Cl}$ & 5,840 & 3,120 & $\mathrm{~Pb}$ & $n / r$ & 2,240 \\
\hline $\mathrm{Co}$ & 4.6 & $n / r$ & $\mathrm{PO}_{4}$ & 518 & 28.3 \\
\hline $\mathrm{Cr}$ & 4,290 & 25,800 & $\mathrm{Si}$ & 2,430 & 2,390 \\
\hline $\mathrm{Cu}$ & 99.8 & $n / r$ & $\mathrm{SO}_{4}$ & 4,140 & 3,270 \\
\hline $\mathrm{F}^{3}$ & $n / r$ & 5.02 & $\mathrm{Sr}$ & 774 & $5 \mathrm{E}-06$ \\
\hline $\mathrm{Fe}$ & 3,140 & 24,500 & TIC as $\mathrm{CO}_{3}$ & 7,560 & 8,930 \\
\hline $\mathrm{Hg}$ & $n / r$ & 74.5 & TOC & 2,770 & 60.5 \\
\hline $\mathrm{K}$ & 548 & 750 & $\mathrm{U}_{\text {total }}$ & 12,200 & 11,000 \\
\hline $\mathrm{La}$ & $n / r$ & $2 \mathrm{E}-06$ & $\mathrm{Zn}$ & 409 & $n / r$ \\
\hline $\mathrm{Mg}$ & 287 & $n / r$ & $\mathrm{Zr}$ & 61.3 & 0.204 \\
\hline
\end{tabular}


Table D2-1. Sampling-Based and Hanford Defined Waste-Based Inventory Estimates for Nonradioactive Components in Tank 241-S-104. (2 sheets)

\begin{tabular}{|c|c|c|c|c|c|}
\hline Analyte & 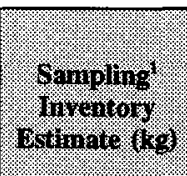 & 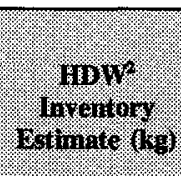 & Araves: & 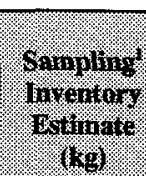 & 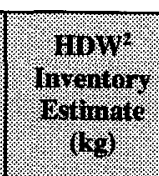 \\
\hline $\mathrm{Mn}$ & 2,100 & 1.84 & $\mathrm{H}_{2} \mathrm{O}(\mathrm{wt} \%)$ & 31.6 & 48.4 \\
\hline $\mathrm{Na}$ & 221,000 & 163,000 & density $(\mathrm{kg} / \mathrm{L})$ & 1.64 & 1.51 \\
\hline $\mathrm{NH}_{4}$ & $n / r$ & 1,240 & & & \\
\hline
\end{tabular}

Notes:

'See Appendix B. Based on 1992 core samples

${ }^{2}$ Agnew et al. (1996)

${ }^{3}$ Fluoride based on water soluble portion only.

Table D2-2. Sampling and HDW Model Predicted Inventory Estimates for Radioactive Components in Tank 241-S-104 (Radionuclides degraded to February 1994).

\begin{tabular}{|c|c|c|c|c|c|}
\hline Anaryse & 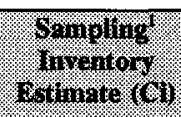 & 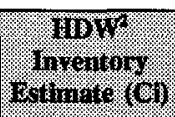 & 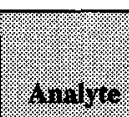 & 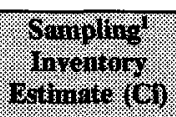 & 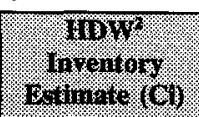 \\
\hline${ }^{14} \mathrm{C}$ & 1.64 & $n / r$ & ${ }^{137} \mathrm{Cs}$ & 109,000 & 211,000 \\
\hline${ }^{90} \mathrm{Sr}$ & 566,000 & 587,000 & $239 / 240 \mathrm{Pu}$ & 515 & 326 \\
\hline${ }^{99} \mathrm{Tc}$ & 44.2 & $n / r$ & Total $\beta$ & $1.17 \mathrm{E}+06$ & $n / r$ \\
\hline
\end{tabular}

Notes:

${ }^{1}$ See Appendix B. Based on 1992 core samples

${ }^{2}$ Agnew et al. (1996) 


\section{D3.0 COMPONENT INVENTORY EVALUATION}

(Please refer to Appendix A, Section A3.1 for a detailed summary of the waste transfer history.)

The following evaluation of tank contents is performed to identify potential errors and/or missing information that would influence the sample-based and HDW model component inventories.

\section{D3.1 EXPECTED TYPE OF WASTE BASED ON THS ASSESSMENT}

Abbreviations used:

$$
\begin{aligned}
& \mathrm{R}=\text { high-level REDOX waste } \\
& \text { CWR }=\text { REDOX cladding waste } \\
& \text { RSltCk }=\text { REDOX saltcake. }
\end{aligned}
$$

The tank volume used to generate the engineering assessment and sampling-based inventories is $1,113 \mathrm{~kL}$ (294 kgal). This volume consists of a 1,109-kL (293-kgal) sludge layer, no saltcake, and $3.8 \mathrm{~kL}$ (1 kgal) of supernatant (Hanlon 1996). The HDW inventories were calculated based on a slightly different mix of sludge and saltcake volumes. Agnew et al. (1996) reports $1,109 \mathrm{~kL}$ (293 kgal) of total waste, which consists of $90.8 \mathrm{~kL}$ (24 kgal) CWR sludge, $408.8 \mathrm{~kL}$ (108 kgal) of R sludge and $609.4 \mathrm{~kL}$ (161 kgal) of saltcake (RSitCk). The Hanlon estimates are being used in the assessment because these volumes were used in the sampling-based inventory and are essentially the same as the Agnew et al. (1996) volume estimates. Agnew et al. (1996) calls out R, CWR and RSltCk. The RSltCk comes mostly from self evaporation and from a careful study of segment and sub-segment data, and appears to be a more concentrated $R$ waste. This TCR estimates the waste to be a combination of $R$ and CWR with about 90 percent R based on Agnew et al. (1995 and 1996).

The mean sludge density that includes interstitial liquid and is used to calculate the sample-based component inventories is $1.64 \mathrm{~g} / \mathrm{mL}$, and the HDW model density for the total solid waste is estimated to be $1.51 \mathrm{~g} / \mathrm{mL}$. Sampling-based and engineering assessment inventories were calculated by multiplying the mean analyte concentration value by the current tank volume and by the sampling-based density of the waste. 


\section{D3.2 ASSUMPTIONS USED FOR THIS ASSESSMENT}

For this evaluation, the following assumptions and observations are made:

- Tank waste mass is calculated using the measured density and the tank volume listed in Hanlon (1996). While this volume may or may not be correct, the analytical-based and the engineering assessment inventories are derived using this volume, and not the slightly different volume reported by Agnew et al. (1996).

- Only the R waste stream and the CWR waste stream contributed to solids formation.

- No radiolysis of $\mathrm{NO}_{3}$ to $\mathrm{NO}_{2}$ and no additions of $\mathrm{NO}_{2}$ to the waste for corrosion purposes are factored into this evaluation.

\section{D3.3 METHODOLOGY USED FOR THIS EVALUATION}

The general approach in this evaluation is to identify waste types and their approximate volumes within the tank of interest. The sources of information may include analytical data from samples taken from the tank of interest, analytical data from other tanks believed to contain waste types similar to those believed to be in the tank of interest, data utilizing process flowsheet information combined with tank contents information, and data from models utilizing historical process records. The confidence level assigned to the best-basis inventory values then depends on the level of agreement among the various information sources, and the number of different waste types in the tank. This approach is, of course, best suited for cases where extensive analytical data exist from multiple sampling events from a number of tanks containing similar waste types.

The sludge in this tank appears to be a combination of R and CWR sludge. Evaluation of segment data from the tanks that show similar waste types (241-S-101, 241-S-104, 241-S-107), the RSltCk segments show analyte concentrations that appear to be very similar to R sludge. In trying to pick sampling segments that only contain CWR waste, no segments or sub-segments were identified that showed significant differences from the $R$ waste below or above, where the CWR layers should have been.

Assessment of waste inventories is based on two separate comparison activities. In the first activity, the process flowsheets for $\mathrm{R}$ and CWR are compared to those predicted by Agnew et al. (1996). The second activity is a process that compares the $\mathbf{R}$ sludge layers from three tanks with the analytical segment data. The average concentrations from these tanks are used to predict the tank inventory. This inventory is later compared to the sampling-based inventory and the HDW model-based inventory. 


\section{D3.3.1 Evaluation of Technical Flowsheet Information}

Process flowsheet and the HDW model molarity information for the R and CWR waste types is shown in Table D3-1. The R and CWR information was averaged over a period of time that includes the waste activity for this tank.

Table D3-1. Technical Process Flowsheet and Los Alamos National Laboratory Defined Waste Streams.

\begin{tabular}{|c|c|c|c|c|}
\hline Analyts: & 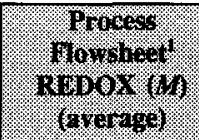 & 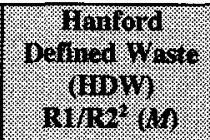 & 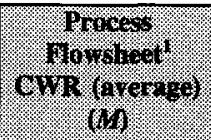 & 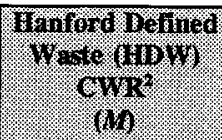 \\
\hline $\mathrm{NO}_{3}$ & 4.53 & 3.3 & 0.63 & 0.885 \\
\hline $\mathrm{NO}_{2}$ & 0 & 0 & 1.3 & 0.85 \\
\hline $\mathrm{SO}_{4}$ & 0.029 & 0.025 & 0 & 0.0125 \\
\hline $\mathrm{Bi}$ & $3 \mathrm{E}-05$ & 0 & 0 & 0.003 \\
\hline $\mathrm{Fe}$ & 0.013 & 0.050 & 0 & 0.0152 \\
\hline Si & 0 & 0.029 & 0.063 & 0.015 \\
\hline $\mathrm{U}$ & 0.0075 & 0.007 & 0.006 & $\overline{0.019}$ \\
\hline $\mathrm{Al}$ & 1.11 & 0.89 & 2.13 & 1.39 \\
\hline $\mathrm{Cr}$ & 0.178 & 0.091 & 0 & 0.003 \\
\hline $\mathrm{Na}$ & 6.98 & 4.14 & 4.9 & 2.87 \\
\hline $\mathrm{K}$ & 0 & 0.015 & 0 & 0.0028 \\
\hline
\end{tabular}

Notes:

R1 = REDOX waste generated 1952-57

$\mathrm{R} 2=$ REDOX waste generated 1958-66

${ }^{1}$ REDOX and CWR Flowsheet average \#5 through \#8 operated from 1955 to 1965 (Kupfer et al. 1996)

${ }^{2}$ Agnew et al. (1996)

\section{D3.3.2 Evaluation Of Sample Information Sources}

The sludge $(\mathrm{R})$ concentrations used in this engineering check comparison were developed with analytical data taken from the following tanks: 241-S-101, 241-S-104, and 241-S-107 (See Section D1.0 for references). While some CWR waste may be intermixed in tank 241-S-104, the same situation applies in the tanks used to predict the $\mathbf{R}$ waste concentration. 
Thus, the $\mathrm{R}$ waste is probably a mixture that includes some CWR and RSltCk waste. Data were selected based on Agnew's predicted sludge location (Agnew et al. 1996). The average concentrations from each tank and the segments used in the calculation are shown in Table D3-2. The mean from each tank was averaged to obtain the projected concentration for each analyte for the $\mathrm{R}$ sludge.

The HDW model concentrations for tank 241-S-104 sludge are also listed in Table D3-2 for comparison with the average concentration values for tanks 241-S-101, 241-S-104 and 241-S-107.

The 241-S-104 inventory estimates are also listed in the last column of Table D3-2. The 241-S-104 inventory calculations for Table D3-2 are:

(average concentration of analyte in $\mu \mathrm{g} / \mathrm{g}$ ) $\times$ (waste in $\mathrm{kgal}$ ) $\times 3,785 \mathrm{~L} / \mathrm{kgal} \mathrm{x}$ $1,000 \mathrm{~mL} / \mathrm{L} \times$ (density in $\mathrm{g} / \mathrm{mL}$ ) $\mathrm{x} \mathrm{kg} /(1 \mathrm{E}+09) \mu \mathrm{g}=$ total $\mathrm{kg}$ for this waste type in the tank.

Table D3-2. Concentrations of Components in REDOX Process Sludges and 241-S-104 Inventory Calculations. (2 sheets)

\begin{tabular}{|c|c|c|c|c|c|c|}
\hline & \multicolumn{3}{|c|}{ Tranks (segungnts) } & Aroruge & IIIOY Voder. & S.104 \\
\hline Amagte & $2416-104$ & 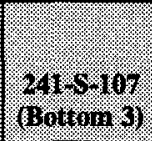 & (Botring & Houcentrifion & Concenrmiton & 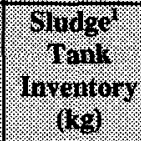 \\
\hline Al & 117,000 & 56,400 & 127,000 & 100,133 & 57,000 & 198,000 \\
\hline $\mathrm{Bi}$ & 45.7 & $n / r$ & $n / r$ & 45.7 & 0.574 & 90.4 \\
\hline $\mathrm{Ca}$ & 247 & 234 & 322 & 268 & 3,480 & 529 \\
\hline $\mathrm{Cl}$ & 3,200 & 1,860 & 2,050 & 2,370 & 1,850 & 4,690 \\
\hline $\mathrm{Cr}$ & 2,350 & 1,180 & 2,230 & 1,920 & 15,400 & 3,800 \\
\hline $\mathrm{F}$ & 145 & 150 & $n / r$ & 148 & 2.98 & 292 \\
\hline $\mathrm{Fe}$ & 1,720 & 1,160 & 1,960 & 1,613 & 14,600 & 3,190 \\
\hline $\mathrm{K}$ & 300 & 457 & 539 & 432 & 446 & 854 \\
\hline $\mathrm{Mn}$ & 1,150 & 83 & 2,750 & 1,328 & 1.10 & 2,630 \\
\hline $\mathrm{Na}$ & 121,000 & 60,400 & 123,000 & 101,467 & 97,100 & 201,000 \\
\hline $\mathrm{Ni}$ & 56 & 206 & 90.7 & 117.6 & 1,050 & 233 \\
\hline $\mathrm{NO}_{2}$ & 25,900 & 34,300 & 31,100 & 30,433 & 55,300 & 60,200 \\
\hline $\mathrm{NO}_{3}$ & 191,000 & 57,600 & 102,000 & 116,867 & 122,000 & 231,000 \\
\hline $\mathrm{Pb}$ & 29.6 & 33 & 37 & 33.2 & 1,340 & 65.7 \\
\hline
\end{tabular}


Table D3-2. Concentrations of Components in REDOX Process Sludges and 241-S-104 Inventory Calculations. (2 sheets)

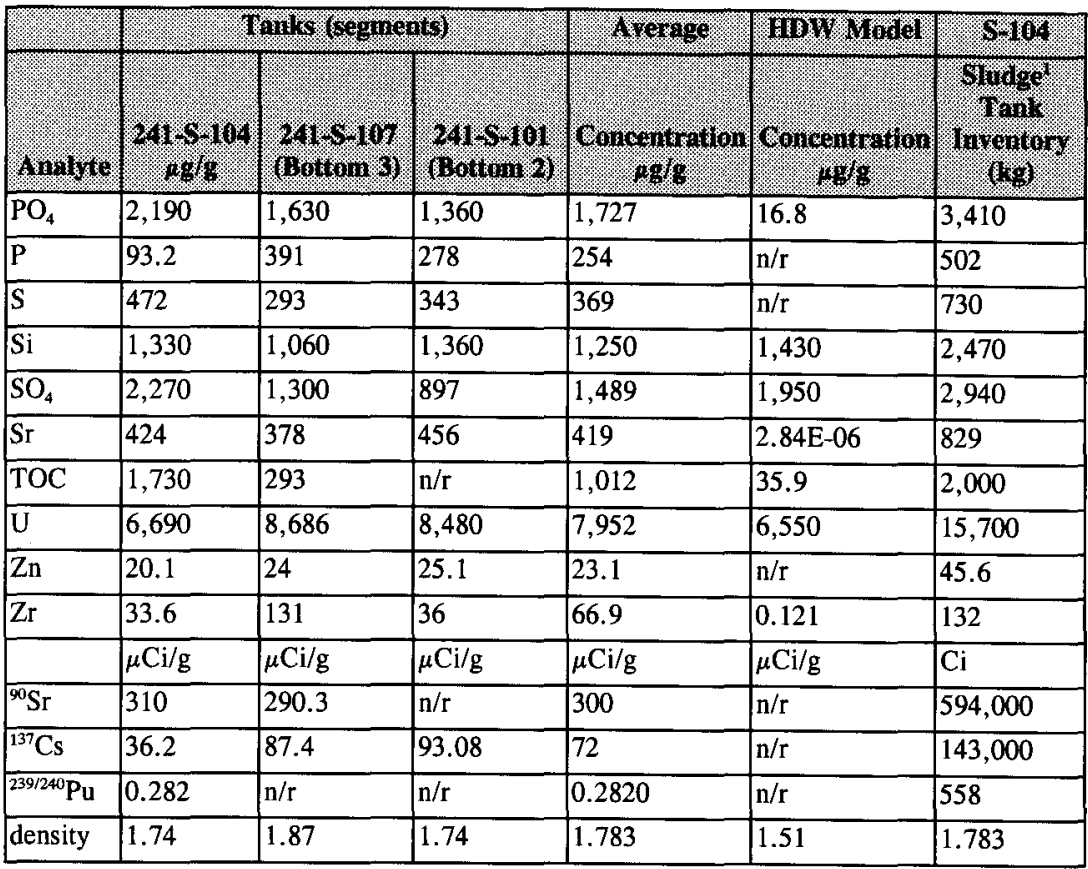

Note:

${ }^{1}$ Based on the average of these tanks (241-S-101, 241-S-104 and 241-S-107)

\section{D.3.4 INVENTORY COMPARISONS}

The engineering assessment-based inventory values, the sampling-based inventories and the HDW model-based inventories are compared in Table D3-3. Selected comparisons follow. 
Table D3-3. Comparison of Selected Component Inventory Estimates for Tank 241-S-104 Waste.

\begin{tabular}{|c|c|c|c|}
\hline (. & 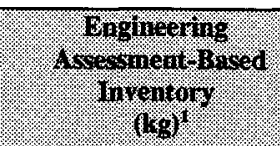 & 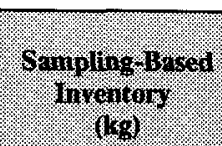 & 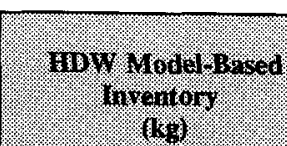 \\
\hline $\mathrm{Al}$ & 198,000 & 214,000 & 95,700 \\
\hline$\overline{\mathrm{Bi}}$ & 90.4 & $<74.9$ & 0.966 \\
\hline $\mathrm{Cl}$ & 4,690 & 5,840 & 3,120 \\
\hline $\mathrm{Cr}$ & 3,800 & 4,290 & 25,800 \\
\hline$\overline{\mathrm{Fe}}$ & 3,190 & 3,140 & 24,500 \\
\hline$\overline{\mathrm{Mn}}$ & 2,630 & 2,100 & 1.84 \\
\hline $\mathrm{Na}$ & 201,000 & 221,000 & 163,000 \\
\hline $\mathrm{NO}_{3}$ & 231,000 & 349,000 & 204,000 \\
\hline $\mathrm{NO}_{2}$ & 60,200 & 38,000 & 92,900 \\
\hline$\overline{S i}$ & 2,470 & 2,430 & 2,390 \\
\hline $\mathrm{SO}_{4}$ & 2,940 & 4,140 & 3,270 \\
\hline$\overline{\mathrm{Sr}}$ & 829 & 774 & $5 \mathrm{E}-06$ \\
\hline TOC & 2,000 & 2,770 & 60.5 \\
\hline $\bar{U}$ & 15,700 & 12,200 & 11,000 \\
\hline $\mathrm{Zr}$ & 132 & 61.3 & 0.204 \\
\hline${ }^{90} \mathrm{Sr}$ & 594,000 & 566,000 & 587,000 \\
\hline${ }^{137} \mathrm{Cs}$ & 143,000 & 114,000 & 211,000 \\
\hline${ }^{239 / 240} \mathrm{Pu}$ & 558 & 515 & 326 \\
\hline $\mathrm{H}_{2} \mathrm{O}$ (percent) & $\mathrm{n} / \mathrm{r}$ & 31.6 & 48.4 \\
\hline
\end{tabular}

Note:

${ }^{1}$ Based on the average concentration for tanks 241-S-101, 241-S-104, 241-S-107. 
Aluminum. The sample-based inventory is about twice the HDW model estimate. Because there is CWR in this tank and the molarity of $\mathrm{Al}$ in CWR is about twice that for R, it is quite possible the larger amount of $\mathrm{Al}$ in this tank is due to the CWR waste. The HDW model-based molarities for $\mathrm{Al}$ are also lower than those of the process flowsheet (Table D3-1).

Sodium. The HDW model inventory is about 25 percent lower than the tank 241-S-104 sample-based inventory. The concentration for sodium in Table 3-2 is higher for the sample-based and engineering assessment-based inventories. In addition, the HDW model assumes a lower density than the analytical samples indicate. Calculated sample values are thus higher than for the HDW model.

Silicon. The Si inventory predicted by the engineering assessment and the HDW model are approximately the same as the sample-based inventory. Both this assessment and the HDW model estimate only about 10 to 11 percent of the Si partitions with the solids in these waste types.

Uranium. The $\mathrm{U}$ inventory predicted by this assessment, the HDW model, and the sample-based inventory are about the same. As stated previously, it is concluded that some of the $U$ partitions to the supernatant and interstitial liquid, likely as a soluble uranyl complex, but most remains with the solids. The process flowsheet and the HDW flowsheet show the same molarity of $U$.

Nitrate. The sample-based inventory is approximately 60 percent higher than that predicted by the HDW model. The process flowsheet molarity is about 15 percent higher than the molarity used for the HDW model. The HDW also assumes less nitrate partitions to the solids. Because of the self evaporation in this tank, it appears that more nitrate precipitated than predicted.

Nitrite. The sample-based inventory for $\mathrm{NO}_{2}$ is approximately 40 percent of that predicted by the HDW model. The R flowsheet does not contain this analyte. The CWR molarity for the process flowsheet is $\mathbf{5 0}$ percent higher than that used for the HDW model. Why the model predicts higher is not due to solubility and thus is unknown at this time. The HDW model may assume significant radiolysis of nitrate to nitrite, which could account for this situation.

Manganese. The sample-based inventory for manganese is 1,000 times that predicted by the HDW model. Mn is listed on earlier process flowsheets for $\mathbf{R}$, and the engineering assessment comparison $(2,630 \mathrm{~kg})$ supports the $2,100 \mathrm{~kg}$ found in this tank, based on the sampling of tank 241-S-104. The HDW model does not assume Mn was used in the flowsheets. 
Chromium. The HDW model-based inventory is about 6 times higher than the sampling-based inventory. The HDW model flowsheet molarity is one half that of the process flowsheet. However, the HDW model shows about 65 percent of the $\mathrm{Cr}$ partitioning to the solids, whereas the sample shows only 7.5 percent partitioning.

Iron. The HDW model predicts 8.7 times more iron than does the sampling-based inventory. The HDW flowsheet shows between 3 to 4 times the molarity of iron as does the process flowsheet. The HDW model also predicts that iron will fully partition to the solids, whereas the sampling-based inventory shows only 70 percent of the iron partitioning to the solids.

TOC. TOC is not a process flowsheet analyte. The sampling-based inventory lists $2,900 \mathrm{~kg}$ of TOC, and only $60.5 \mathrm{~kg}$ is predicted by the HDW model. The engineering assessment-based inventory $(2,000 \mathrm{~kg})$ supports the sampling-based information. The HDW model does not account for this organic inventory in its treatment of this and similar tanks.

\section{D4.0 DEFINE THE BEST-BASIS AND ESTABLISH COMPONENT INVENTORIES}

Information about chemical, radiological, and/or physical properties is used to perform safety analyses, engineering evaluations, and risk assessments associated with waste management activities, and to address regulatory issues. These activities include overseeing tank farm operations and identifying, monitoring, and resolving safety issues associated with these operations and with the tank wastes. Disposal activities involve designing equipment and facilities for retrieving wastes and processing them into a form suitable for long-term storage. Chemical and radiological inventory information is generally derived using one of three approaches: (1) component inventories are estimated using results of sample analyses; (2) component inventories are estimated using the HDW Model based on process knowledge and historical information; or (3) a tank-specific process estimate is made based on process flowsheets, reactor fuel data, essential material usage, and other operating data. Not surprisingly, the information derived from these different approaches is often inconsistent.

An effort is underway to provide inventory estimates that will serve as the standard characterization for the various waste management activities (Hodgson and LeClair 1996). As part of this effort, an evaluation of available chemical information for tank 241-S-104 was performed, including:

- Data from three push mode 1992 core samples (See Appendix B, Section B2.0)

- An inventory estimate generated by the HDW model (Agnew et al. 1996) 
- Comparison with the R/CWR sludge values based on the concentration and partitioning of these wastes within the tank, which can be evaluated by comparison to similar tanks.

- Comparison with the average composite analytical segment concentrations of similar tanks containing these waste types.

Based on this evaluation, a best-basis inventory was developed for tank 241-S-104 for which sampling information was available. For the following reasons, the sampling-based inventory was chosen as the best basis for those analytes for which sampling-based analytical values were available:

- The sampling-based inventory analytical concentrations compared favorably to those of two other $\mathrm{R}$ tanks (to the extent this is known at this time)

- The HDW model does not agree with the other sampling-based inventories for $\mathrm{R}$ tanks in several cases

- The engineering assessment using the original process flow streams supports the assumption that the sampling-based data appear reasonable

- Comparison of similar waste segment levels from tanks with the same wastes supports the assumption that the sampling-based data appear reasonable

- For those few analytes where no values were available from the sampling-based inventory, the engineering assessment-based inventory, or the engineering check comparison-based inventory, the HDW model-based inventory values were used, with the notation that they were of lower reliability

The best-basis inventory for tank 241-S-104 is presented in Tables D4-1 and D4-2. 
Table D4-1. Best-Basis Inventory Estimates for Nonradioactive Components in Tank 241-S-104 (December 4, 1996).

\begin{tabular}{|c|c|c|c|}
\hline 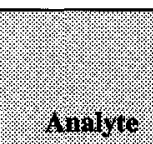 & 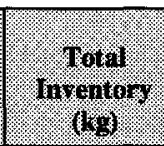 & 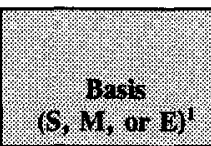 & 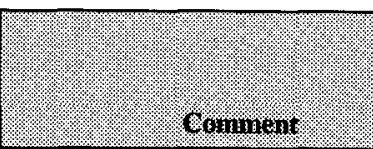 \\
\hline $\mathrm{Al}$ & 214,000 & $S$ & \\
\hline $\mathrm{Bi}$ & $<74.9$ & $S$ & Engineering assessment $=90.4$ \\
\hline $\mathrm{Ca}$ & 7,700 & $S$ & \\
\hline $\mathrm{Cl}$ & 5,840 & $S$ & \\
\hline TIC as $\mathrm{CO}_{3}$ & 7,560 & $S$ & \\
\hline $\mathrm{Cr}$ & 4,290 & $S$ & \\
\hline F & 292 & E & \\
\hline $\mathrm{Fe}$ & 3,140 & $S$ & \\
\hline $\mathrm{Hg}$ & 74.5 & $\mathbf{M}$ & \\
\hline $\mathrm{K}$ & 548 & $S$ & \\
\hline $\mathrm{La}$ & $2 \mathrm{E}-06$ & $M$ & \\
\hline Mn & 1,890 & $\bar{S}$ & \\
\hline $\mathrm{Na}$ & 220,000 & S & \\
\hline $\mathrm{Ni}$ & 102 & $\mathrm{~S}$ & \\
\hline $\mathrm{NO}_{2}$ & 38,000 & $S$ & \\
\hline $\mathrm{NO}_{3}$ & 349,000 & $S$ & \\
\hline $\mathrm{OH}$ & $n / r$ & & \\
\hline $\mathrm{Pb}$ & 65.7 & $\mathrm{E}$ & The $\mathbf{M}$ value $=2,240$ \\
\hline $\mathrm{P}$ as $\mathrm{PO}_{4}$ & 518 & $\mathrm{~S}$ & \\
\hline $\mathrm{Si}$ & 2,430 & $S$ & \\
\hline $\mathrm{S}$ as $\mathrm{SO}_{4}$ & 4,140 & $S$ & \\
\hline $\mathrm{Sr}$ & 774 & $S$ & \\
\hline TOC & 2,770 & $S$ & \\
\hline $\mathrm{U}_{\text {TOTAL }}$ & 12,200 & $\mathrm{~S}$ & \\
\hline$\overline{\mathrm{Zr}}$ & 61.2 & $S$ & \\
\hline
\end{tabular}

Notes:

$$
{ }^{1} \mathrm{~S}=\text { Sample-based, } \mathrm{M}=\text { HDW model-based, } \mathrm{E}=\text { Engineering assessment-based. }
$$


Table D4-2. Best-Basis Inventory Estimates for Radioactive Components in Tank 241-S-104 (Radionuclides decayed to January 1, 1994) (December 4, 1996).

\begin{tabular}{|c|c|c|c|}
\hline 1. Analye & $\begin{array}{l}\text { Total inveritong } \\
(\mathrm{Cl})\end{array}$ & 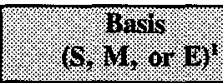 & Comment \\
\hline${ }^{3} \mathrm{H}$ & 6.15 & $\mathrm{~S}$ & \\
\hline${ }^{14} \mathrm{C}$ & 1.64 & $\mathrm{~S}$ & \\
\hline${ }^{90} \mathrm{Sr}$ & 566,000 & $\mathrm{~S}$ & \\
\hline${ }^{90} \mathrm{Y}$ & 566,000 & $\mathrm{~S}$ & From ${ }^{90} \mathrm{Sr}$ \\
\hline${ }^{99} \mathrm{Tc}$ & 44.2 & $\mathrm{~S}$ & \\
\hline$\overline{{ }^{137} \mathrm{Cs}}$ & 114,000 & $S$ & \\
\hline${ }^{137 \mathrm{~m}} \mathrm{Ba}$ & 107,000 & $\mathrm{~S}$ & From ${ }^{137 m} \mathrm{Cs}$ \\
\hline${ }^{239} \mathrm{Pu}$ & 515 & $\bar{S}$ & *includes ${ }^{240} \mathrm{Pu}$ \\
\hline
\end{tabular}

Notes:

${ }^{1} \mathrm{~S}=$ Sample-based, $\mathrm{M}=$ HDW model-based, $\mathrm{E}=$ Engineering assessment-based.

\section{D5.0 APPENDIX D REFERENCES}

Agnew, S. F., R. A. Corbin, T. B. Duran, K. A. Jurgensen, T. P. Ortiz, and B. L. Young 1995, Waste Status and Transaction Record Summary (WSTRS Rev. 2),

WHC-SD-WM-TI-615, 614, 669, and 689, Rev. 2, Westinghouse Hanford Company, Richland, Washington.

Agnew, S. F., J. Boyer, R. A. Corbin, T. B. Duran, J. R. FitzPatrick, K. A. Jurgensen, T. P. Ortiz, and B. L. Young, 1996, Hanford Tank Chemical and Radionuclide Inventories: HDW Model Rev. 3, LA-UR-96-858, Rev. 0, Los Alamos National Laboratory, Los Alamos, New Mexico.

Hanlon, B. M., 1996, Waste Tank Summary Report for Month Ending June 30, 1996, WHC-EP-0182-99, Westinghouse Hanford Company, Richland, Washington.

Hodgson, K. M, and M. D. LeClair, 1996, Work Plan for Defining a Standard Inventory Estimate for Wastes Stored in Hanford Site Underground Tanks, WHC-SD-WM-WP-311, Rev. 1, Lockheed Martin Hanford Corporation, Richland, Washington. 
Kruger, Albert A, B. J. Morris and L. J. Fergestrom, 1996, Tank Characterization Report for Single-Shell Tank 241-S-101, WHC-SD-WM-ER-613, Rev. 0, Westinghouse Hanford Company, Richland, Washington.

Kupfer, M. J., A. L. Boldt, B. A. Higley, L. W. Shelton, R. A. Watrous, S. L. Lambert, D. E. Place, R. M. Orme, G. L. Borsheim, N. G. Colton, M. D. LeClair, D. Hedengren, R. T. Winward, and W. W. Schulz, 1996, Standard Inventories of Chemicals and Radionuclides in Hanford Site Tank Wastes, HNF-SD-WM-TI-740, Rev. 0, Lockheed Martin Hanford Corporation, Richland, Washington.

Simpson, Brett C., J. G. Field, D. W. Engel and D. S. Daly, 1996, Tank Characterization Report for Single-Shell Tank 241-S-107, WHC-SD-WM-ER-589, Rev. 0, Westinghouse Hanford Company, Richland, Washington. 
HNF-SD-WM-ER-370 Rev. 1

This page intentionally left blank.

D-18 
HNF-SD-WM-ER-370 Rev. 1

APPENDIX E

BIBLIOGRAPHY FOR TANK 241-S-104

E-1 


\section{APPENDIX E}

\section{BIBLIOGRAPHY FOR TANK 241-S-104}

Appendix E provides a bibliography of information that supports the characterization of tank 241-S-104. This bibliography represents an in-depth literature search of all known information sources that provide sampling, analysis, surveillance, and modeling information, as well as processing occurrences associated with tank 241-S-104 and its respective waste types.

The references in this bibliography are separated into three broad categories containing references broken down into subgroups. These categories and their subgroups are listed below.

\section{NON-ANALYTICAL DATA}

Ia. Models/Waste Type Inventories/Campaign Information

Ib. Fill History/Waste Transfer Records

Ic. Surveillance/Tank Configuration

Id. Sample Planning/Tank Prioritization

Ie. Data Quality Objectives/Customers of Characterization Data

\section{ANALYTICAL DATA - SAMPLING OF TANK WASTE AND WASTE TYPES}

Ila. Sampling of Tank 241-S-104

\section{COMBINED ANALYTICAL/NON-ANALYTICAL DATA}

IIIa. Inventories using both Campaign and Analytical Information

IIIb. Compendium of Existing Physical and Chemical Documented Data Sources

This bibliography is broken down into the appropriate sections of material to use, with an annotation at the end of each reference describing the information source. Where possible, a reference is provided for information sources. A majority of the information listed below may be found in the Lockheed Martin Hanford Corporation Tank Characterization Resource Center. 


\section{NON-ANALYTICAL DATA}

\section{Ia. Models/Waste Type Inventories/Campaign Information}

Agnew, S. F., J. Boyer, R. A. Corbin, T. B. Duran, J. R. Fitzpatrick, K. A. Jurgensen, T. P. Ortiz, and B. L. Young, 1996, Hanford Tank Chemical and Radionuclide Inventories: HDW Model Rev. 3, LA-UR-96-858, Rev. 0, Los Alamos National Laboratory, Los Alamos, New Mexico.

- Document contains tank layer and supernatant models and the historical tank content estimate for Hanford Site underground waste storage tanks, as well as a list of Hanford Site waste types.

Anderson, J. D., 1990, A History of the 200 Area Tank Farms, WHC-MR-0132, Westinghouse Hanford Company, Richland, Washington.

- Document contains single-shell tank fill history and primary campaign/waste type information up to 1981 .

Boldt, A. L., 1966, REDOX Chemical Flowsheet HW No. 9, ISO-335, Isochem, Inc., Richland, Washington.

- Document contains compositions of material balance for REDOX process as well as a separations plan denoting process stream waste before transfer to 200 Area waste tanks.

Crawley, D. T., 1960, REDOX Chemical for sheet HW-No. 6, HW-66203, Hanford Atomic Products Operation, General Electric Company, Richland, Washington.

- Document contains compositions of material balance for REDOX process as well as a separations plan denoting process stream waste before transfer to 200 Area waste tanks. 
Jungfleisch, F. M. and B. C. Simpson, 1993, Preliminary Estimation of the Waste Inventories in Hanford Tanks Through 1980 , WHC-SD-WM-TI-057, Rev. 0A, Westinghouse Hanford Company, Richland, Washington.

- A model based on process knowledge and radioactive decay estimations using ORIGEN for different compositions of process waste streams assembled for total, solution, and solids compositions per tank. Assumptions about waste/waste types and solubility parameters/constraints are also given.

Merrill, E. T. and R. L. Stevenson, 1995, REDOX Chemical Flowsheet HW No. 5, HW-38684, Hanford Atomic Products Operation, Richland, Washington.

- Document contains compositions of material balance for REDOX process as well as a separations plan denoting process stream waste before transfer to 200 Area waste tanks.

Schneider, K. J., 1951, Flow Sheet and Flow Diagrams of Precipitation Separations Process, HW-23043, General Electric Company, Richland, Washington.

- Document contains compositions of first concentration cycle waste before transfer to $200 \mathrm{E}$ waste tanks.

\section{Ib. Fill History/Waste Transfer Records}

Agnew, S. F., R. A. Corbin, T. B. Duran, K. A. Jurgensen, T. P. Ortiz, and B. L. Young, 1996, Waste Status and Transaction Record Summary for the Southwest Quadrant of the Hanford 200 East Area, WHC-SD-WM-TI-614, Rev. 1, Los Alamos National Laboratory, Los Alamos, New Mexico.

- Document contains spreadsheets depicting all available data on tank additions/transfers.

Anderson, J. D., 1990, A History of the 200 Area Tank Farms, WHC-MR-0132, Westinghouse Hanford Company, Richland, Washington.

- Document contains single-shell tank fill history and primary campaign/waste type information up to 1981 . 
Koreski, G. M., 1991, Operational Waste Volume Projection, WHC-SD-WM-ER-029, Rev. 0, Westinghouse Hanford Company, Richland, Washington.

- Contains spreadsheets depicting all available data on tank additions/transfers from 1981 up to 1991.

\section{Ic. Surveillance/Tank Configuration}

Alstad, A. T., 1993, Riser Configuration Document for Single-Shell Waste Tanks, WHC-SD-RE-TI-053, Rev. 9, Westinghouse Hanford Company, Richland, Washington.

- Document shows tank riser locations in relation to tank aerial view as well as a description of riser and its contents.

Baumhart, R. J., 1989, Single-Shell Tank Leak Volumes, (letter \#89011832BR1 to R. E. Gerton, U.S. Department of Energy, Richland Operations Office, May 17), Westinghouse Hanford Company, Richland, Washington.

- Letter report estimating leak volumes for single-shell tanks.

Baumhart, R. J. 1988, Interim Isolation of Tanks T-105, T-109, and S-104, (letter \#8856251 to R. E. Gerton, U.S. Department of Energy, Richland Operations Office, October 12), Westinghouse Hanford Company, Richland, Washington.

Graham, M. J., 1981, Moisture Reading in Dry Wells in S and SX Tank Farms, (internal memorandum \#72710-81-275 to W. F. Hale, August 17), Rockwell Hanford Operations, Richland, Washington.

- Letter report concerning neutron probe readings in dry wells.

Jones, A. L., 1987, Stabilization of Sludge Tanks, (internal memorandum \#65950-87-093 to J. C. Womack, March 20), Rockwell Hanford Operations, Richland, Washington.

- Memorandum addresses porosity issues for stabilization of sludge tanks. 
Lipnicki, J., 1996, Waste Tank Risers Available for Sampling, WHC-SD-WM-TI-710, Rev. 3, Westinghouse Hanford Company, Richland, Washington.

- Document gives an assessment of riser locations for each tank; however not all tanks are included/completed. Also included is an estimate of what risers are available for sampling.

Raymond, H. N., 1972, Maximum Operating Levels and Cascade Levels in 200W Area Tank Farms, (internal letter \#LET-082172 to C. J. Francis, August 21), Atlantic Richfield Hanford Company, Richland, Washington.

- Letter reports maximum operating level.

Schmidt, W. C, 1977, Tank Isolation Project Photographs, (internal memorandum \#RI-072077 to W. Schick, July 20), Rockwell International, Richland, Washington.

- Letter contains the dates of in-tank photographs.

Swenson, J. A., 1978, 1978 Surveys of $241 S 241$ U 241-SY Farms, (internal memorandum \#LET-041478 to B. J. Saueressig, March 26), Rockwell Hanford Operation, Richland, Washington.

- Letter contains the results of radiation survey of contaminated risers.

Tran, T. T., 1993, Thermocouple Status Single-Shell and Double-Shell Waste Tanks, WHC-SD-WM-TI-553, Rev. 0, Westinghouse Hanford Company, Richland, Washington.

- Compilation information on thermocouple trees installed in Hanford Site underground waste tanks.

Welty, R. K., 1988, Waste Storage Tank Status and Leak Detection Criteria, Volumes I and II, WHC-SD-WM-TI-356, Rev. 0, Westinghouse Hanford Company, Richland, Washington.

- Describes the nature, scope, and frequency of surveillance employed for waste storage tanks, states action criteria for response to data deviation, and presents tank data reviews between June 15, 1973 and June $15,1988$. 
Id. Sample Planning/Tank Prioritization

Brown, T. M., S. J. Eberlein, J. W. Hunt, and T. J. Kunthara, 1996, Tank Waste Characterization Basis, WHC-SD-WM-TA-164, Rev. 2, Westinghouse Hanford Company, Richland, Washington.

- Document that summarizes the technical basis for characterizing the waste in the tanks and assigns a priority number to each tank.

Grimes, G. W., 1977, Hanford Long-Term Defense High-Level Waste Management Program Waste Sampling and Characterization Plan, RHO-CD-137, Rockwell Hanford Operations, Richland, Washington.

- Early characterization planning document.

Winkelman, W. D., J. W. Hunt, and L. J. Fergestrom, 1997, FY 1997 Tank Waste Analysis Plan, WHC-SD-WM-PLN-120, Rev. 1, Westinghouse Hanford Company, Richland, Washington.

- Document contains Tri-Party Agreement (see Ecology et al. 1996 listing in Section 5.0) requirement-driven TWRS Characterization Program information and a list of tanks addressed in fiscal year 1997.

Winters, W. I., L. Jensen, L. M. Sasaki, R. L. Weiss, J. F. Keller, A. J. Schmidt, and M. G. Woodruff, 1989, Waste Characterization Plan for the Hanford Site Single-Shell Tanks, WHC-EP-0210, Westinghouse Hanford Company, Richland, Washington.

- Early version of characterization planning document.

Ie. Data Quality Objectives (DQO) and Customers of Characterization Data

Dukelow, G. T., J. W. Hunt, H. Babad, and J. E. Meacham, 1995, Tank Safety Screening Data Quality Objective, WHC-SD-WM-SP-004, Rev. 2, Westinghouse Hanford Company, Richland, Washington.

- DQO used to determine if tanks are under safe operating conditions.

Kupfer, M. J., W. W. Schultz, G. L. Borsheim, S. J. Eberlein, B. C. Simpson, and J. T. Slankas, 1994, Strategy for Sampling Hanford Site Tank Wastes for Development of Disposal Technology, WHC-SD-WM-TA-154, Rev. 1, Westinghouse Hanford Company, Richland, Washington.

- Document provides basis for selection of tanks for disposal needs. 
Slankas, T. J., M. J. Kupfer, and W. W. Schulz, 1995, Data Needs and Attendant Data Quality Objectives for Tank Waste Pretreatment and Disposal, WHC-SD-WM-DQO-022, Rev. 0, Westinghouse Hanford Company, Richland, Washington.

- Documents the needs of the pretreatment function within TWRS.

\section{ANALYTICAL DATA - SAMPLING OF TANK WASTE AND WASTE TYPES}

IIa. Sampling of Tank 241-S-104

Cromar, R. D., 1994, Statistical Characterization Report for Single-Shell Tank 241-S-104, WHC-SD-WM-WM-652, Rev. 0, Westinghouse Hanford Company, Richland, Washington.

- Document contains the results of the statistical analysis of data from Tank 241-S-104.

Horton, J. E., 1976, Characterization \& Analysis of Tank S-104 Sludge, (internal memo \#022476 to W. R. Christensen, February 24), Atlantic Richfield Hanford Company, Richland, Washington.

- Letter report of tank 241-S-104 sludge analysis.

Johnston, R. G., 1981, Submission of Letter Report on Radiolytic Gas Generation in Bitumen Concrete Waste Forms Fulfilling Milestone, (internal memo \#65470-81-065 to I. E. Reep, March 20), Rockwell Hanford Operation, Richland, Washington.

- Letter describes radiolytic gas generation from concrete and bitumen waste form.

Kirk, J. J., 1980, Permeability, Porosity \& Capillarity of Hanford Waste Material \& Its Limits of Pumpability, RHO-CD-925 Rev. 2, Rockwell Hanford Operation, Richland, Washington.

- Study of pumpability and drainability report.

Kocher, K. L., 1993, Single Shell Waste Characterization Tank 241-S-104 Data Package, WHC-SD-WM-DP-031, Rev. 0, Richland Washington.

- Laboratory report for 1992 core sampling event. 
Wisness, S. H., 1993, Transmittal of Data Package \& Validation Summary for Core Samples from 241-S-104, (letter \#9303061 to S. E. McKinney, Washington State Department of Ecology, April 6), Department of Energy Richland Office, Richland, Washington.

- Letter transmits tank 241-S-104 core sample analyses to Washington State Department of Ecology.

\section{COMBINED ANALYTICAL/NON-ANALYTICAL DATA}

IIIa. Inventories from Campaign and Analytical Information

Agnew, S. F., J. Boyer, R. A. Corbin, T. B. Duran, J. R. Fitzpatrick, K. A. Jurgensen, T. P. Ortiz, and B. L. Young, 1995, Hanford Tank Chemical and Radionuclide Inventories: HDW Rev. 3, LA-UR-96-858, Rev. 0, Los Alamos National Laboratory, Los Alamos, New Mexico.

- Document contains waste type summaries as well as primary chemical compound/analyte and radionuclide estimates for sludge, supernatant, and solids.

Allen, G. K., 1976, Estimated Inventory of Chemicals Added to Underground Waste Tanks, 1944 - 1975, ARH-CD-601B, Atlantic Richfield Hanford Company, Richland, Washington.

- Document contains major components for waste types, and some assumptions. Purchase records are used to estimate chemical inventories.

Allen, G. K., 1975, Hanford Liquid Waste Inventory As Of September 30, 1974, ARH-CD-229, Atlantic Richfield Hanford Company, Richland, Washington.

- Document contains major components for waste types, and some assumptions.

IIIb. Compendium of data from other sources physical and chemical

Agnew, S. F., and J. G. Watkin, 1994, Estimation of Limiting Solubilities for Ionic Species in Hanford Waste Tank Supernates, LAUR-94-3590, Los Alamos National Laboratory, Los Alamos, New Mexico.

- Document gives solubility ranges used for key chemical and radionuclide components based on supernatant sample analyses. 
Brevick, C. H., L. A. Gaddis, and E. D. Johnson, 1995, Historical Tank Content Estimate for the Northwest Quadrant of the Hanford 200 Areas, WHC-SD-WM-ER-351, Rev. 0, Westinghouse Hanford Company, Richland, Washington.

- Document contains summary information from the supporting document as well as in-tank photo collages and the solid composite inventory estimates Rev. 0 and Rev. $0 \mathrm{~A}$.

Brevick, C. H., L. A. Gaddis, and W. W. Pickett, 1995, Supporting Document for the Historical Tank Content Estimate for T Tank Farm, WHC-SD-WM-ER-320, Rev. 0, Westinghouse Hanford Company, Richland, Washington.

- Document contains summary tank farm and tank write-ups on historical data and solid inventory estimates, as well as appendixes for the data. The appendixes contain the following information: Appendix C - Level History AutoCAD sketch; Appendix D - Temperature Graphs; Appendix E - Surface Level Graph; Appendix F, pg. F-1 Cascade/Drywell Chart; Appendix G - Riser Configuration Drawing and Table; Appendix I In-Tank Photos; and Appendix K - tank layer Model Bar Chart and Spreadsheet.

Brevick, C. H., L. A. Gaddis, and E. D. Johnson, 1995, Tank Waste Source Term Inventory Validation, Vol I \& II., WHC-SD-WM-ER-400, Rev. 0, Westinghouse Hanford Company, Richland, Washington.

- Document contains a quick reference to sampling information in spreadsheet or graphical form for 23 chemicals and 11 radionuclides for all the tanks.

Endow, N., 1954, Field Corrosion Test SAE 1020 Carbon Steel in REDOX Process, HW 32755, General Electric Company, Richland, Washington.

- Report of the corrosion rates in REDOX waste.

Fraser, M. C., 1974, Radionuclide Inventories in Leaks from Transfer Lines and Tanks, (internal letter 013074 to H. P. Shaw, January 30), Atlantic Richfield Hanford Company, Richland, Washington.

- Letter reports amount of waste and radionuclide inventory leaked from transfer lines and tanks. 
Hanlon, B. M., 1996, Waste Tank Summary Report for Month Ending April 30, 1996, WHC-EP-0182-97, Westinghouse Hanford Company, Richland, Washington.

- Document contains a monthly summary of: fill volumes, Watch List tanks, occurrences, integrity information, equipment readings, equipment status, tank location, and other miscellaneous tank information.

Husa, E. I., 1993, Hanford Site Waste Storage Tank Information Notebook, WHC-EP-0625, Westinghouse Hanford Company, Richland, Washington.

- Document contains in-tank photos as well as summaries on the tank description, leak detection system, and tank status.

Husa, E. I., 1995, Hanford Waste Tank Preliminary Dryness Evaluation, WHC-SD-WM-TI-703, Rev. 0, Westinghouse Hanford Company, Richland, Washington.

- Document gives assessment of relative dryness between tanks. 


\section{DISTRIBUTION SHEET}

\begin{tabular}{|c|c|c|c|c|c|}
\hline \multirow[b]{2}{*}{ bution } & \multirow{2}{*}{\multicolumn{3}{|c|}{ From }} & \multicolumn{2}{|l|}{ Page 1 of 3} \\
\hline & & & & \multicolumn{2}{|c|}{$03 / 10 / 97$} \\
\hline \multicolumn{4}{|l|}{ Project Title/Work Order } & \multicolumn{2}{|l|}{ EDT No. $N / A$} \\
\hline \multicolumn{4}{|c|}{$\begin{array}{l}\text { Tank Characterization Report for Single-She } 11 \text { Tank 241-S-104, } \\
\text { HNF-SD-WM-ER-370, Rev. } 1\end{array}$} & \multicolumn{2}{|c|}{ ECN No. $\quad E C N-635446$} \\
\hline Name & MSIN & $\begin{array}{l}\text { Text } \\
\text { With All } \\
\text { Attach. }\end{array}$ & Text Only & $\begin{array}{l}\text { Attach./ } \\
\text { Appendix } \\
\text { Only }\end{array}$ & $\begin{array}{l}\text { EDT/ECN } \\
\text { Only }\end{array}$ \\
\hline
\end{tabular}

\section{DFFSITE}

Sandia Nationa? Laboratory

P. 0. Box 5800

MS-0744, Dept. 6404

Albuquerque. NM 87815

D. Powers

Nuclear Consulting Services Inc.

P. 0. Box 29151

Columbus, OH 43229-01051

J. L. Kovach

$x$

Chemical Reaction Sub-TAP

P.0. Box 271

Lindsborg. KS 67456

B. C. Hudson

$x$

Tank Characterization Pane $]$

Senior Technical Consultant

contech

7309 Indian School Road

Albuquerque. NM 87110

J. Arvisu

$x$

SAIC

$\frac{}{20300}$ Century Boulevard, Suite 200-B

Germantown. MD 20874

H. Sutter

$x$

Los Alamios Laboratory

CST-14 MS-J586

P. 0. Box 1663

Los Alamos, NM 87545

S. F. Agnew

$x$ 


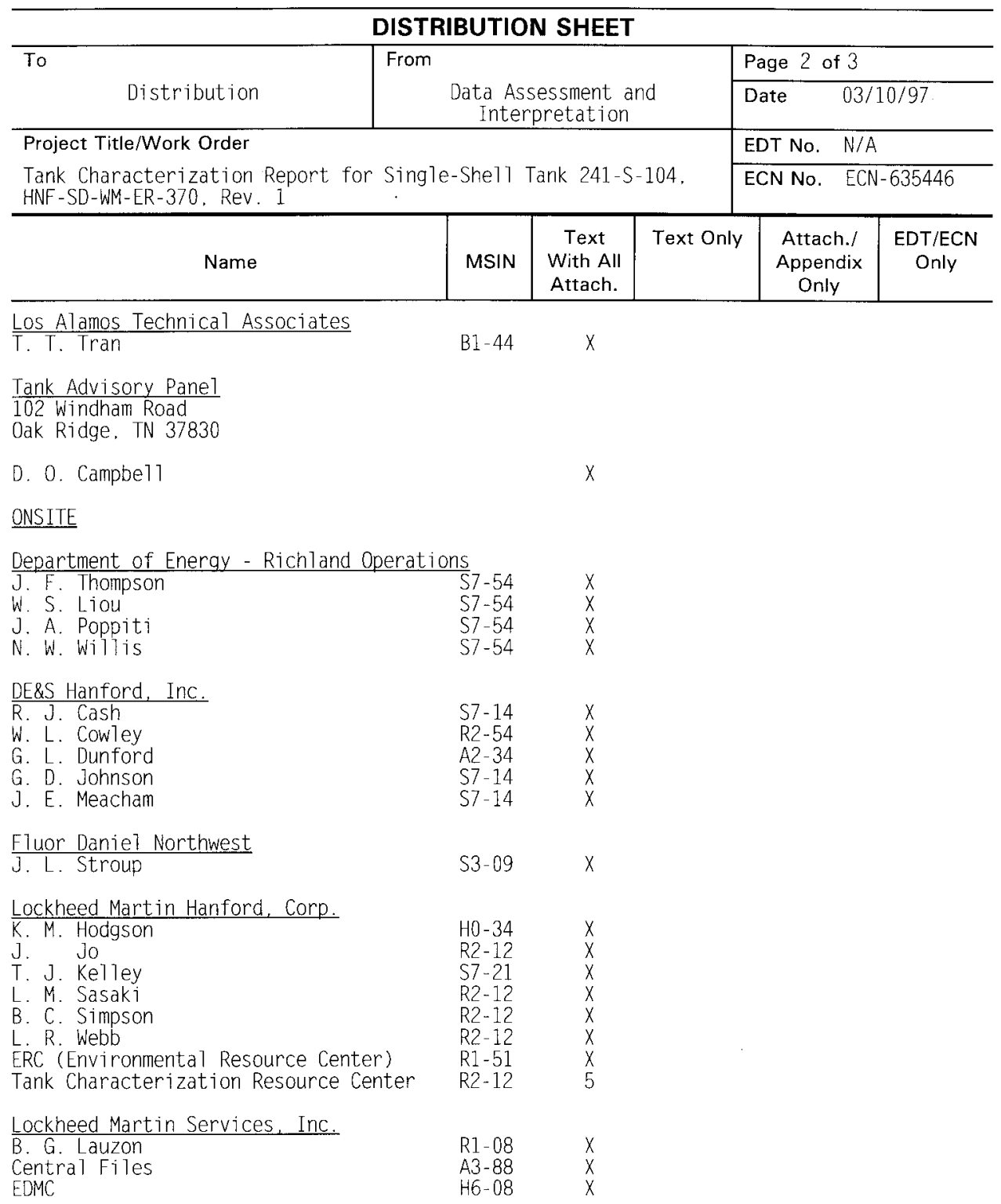




\section{DISTRIBUTION SHEET}

\begin{tabular}{|c|c|c|c|c|c|}
\hline \multirow[b]{2}{*}{ ibution } & \multirow{2}{*}{\multicolumn{3}{|c|}{ From }} & \multicolumn{2}{|l|}{ Page 3 of 3} \\
\hline & & & & \multicolumn{2}{|c|}{$03 / 10 / 97$} \\
\hline \multicolumn{4}{|l|}{ Project Title/Work Order } & \multicolumn{2}{|l|}{ EDT No. $\quad \mathrm{N} / \mathrm{A}$} \\
\hline \multicolumn{4}{|c|}{$\begin{array}{l}\text { Tank Characterization Report for Single-She } 11 \text { Tank 241-S-104, } \\
\text { HNF-SD-WM-ER-370. Rev. } 1\end{array}$} & \multicolumn{2}{|c|}{ ECN No. $\quad$ ECN-635446 } \\
\hline Name & MSIN & $\begin{array}{c}\text { Text } \\
\text { With All } \\
\text { Attach. }\end{array}$ & Text Only & $\begin{array}{l}\text { Attach./ } \\
\text { Appendix } \\
\text { Only }\end{array}$ & $\begin{array}{l}\text { EDT/ECN } \\
\text { Only }\end{array}$ \\
\hline
\end{tabular}

Numatec Hanford Corporation

J. S. Garfietd

J. S. Hertzel

D. L. Lamberd

H5- 49

$45-61$

$45-61$

$x$
$X$
$X$

Pacific Northwest National Laboratory

A. F. Noonan

K9-91 $\quad x$

Rust Federal Services of Hanford, Inc.

C. T. Narquis

T6-16 $\quad x$

SGN Eurisys Services Corp.

D. B. Engelman

L6-37 X

